\title{
4. SITE 305: SHATSKY RISE
}

\author{
The Shipboard Scientific Party ${ }^{1}$
}

\author{
SITE DATA \\ Date Occupied: 29 August 1973 (2039) \\ Date Departed: 3 September 1973 (1944) \\ Time on Site: 119 hours \\ Position: $32^{\circ} 00.13^{\prime} \mathrm{N}, 157^{\circ} 51.00^{\prime} \mathrm{E}$ \\ Water Depth: 2903 corrected meters (echo sounding) \\ Bottom Felt With Drill Pipe At: 2921 meters below rig floor \\ Penetration: 640.5 meters \\ Number of Holes: 1 \\ Number of Cores: 68 \\ Total Length of Cored Section: 631.0 meters \\ Total Core Recovered: 210.6 meters
}

\section{BACKGROUND AND OBJECTIVES}

A number of oceanographic expeditions have investigated Shatsky Rise, an irregular, plateau-like feature elevated above the general depth of the northwestern Pacific. Mesozoic sediments were dredged and piston-cored from Shatsky Rise, and seismic reflection profiles show a thick section of sediment to be capping the elevated basement. The rise was a high priority objective for Legs 6 and 20 during earlier phases in the Pacific of the Deep Sea Drilling Project. On Leg 6 several holes were attempted at four sites with little success. Mesozoic cherty rocks penetrated in cores and a pre-middle Miocene unconformity provided barriers to the establishment of a complete biostratigraphic record. Leg 20 was beset with operational difficulties and the Shatsky Rise site was eliminated from the actual track. The Pacific Advisory Panel of JOIDES considered no objective in the 1973 Pacific legs to be of higher priority than a continuously cored section through Shatsky Rise.

The rises and plateaus previously cored have proven to be optimum locations for the preservation of planktonic foraminifera, radiolarians, and nannofossils. Biostratigraphic zonations based on sections where all three fossil groups are present can be more discriminating than zonations based on one group alone.

'Roger L. Larson, Lamont-Doherty Geological Observatory, Palisades, New York (Co-chief scientist); Ralph Moberly, Hawaii Institute of Geophysics, Honolulu, Hawaii (Co-chief scientist); David Bukry, U.S. Geological Survey, La Jolla, California; Helen P. Foreman, Oberlin College, Oberlin, Ohio; James V. Gardner, Scripps Institution of Oceanography, La Jolla, California; John B. Keene, Scripps Institution of Oceanography, La Jolla, California; Yves Lancelot, Lamont-Doherty Geological Observatory, Palisades, New York; Hanspeter Luterbacher, Esso Production Research-European, Begles, France; Monte C. Marshall, U. S. Geological Survey, Menlo Park, California; Albert Matter, Universitat Bern, Bern, Switzerland.

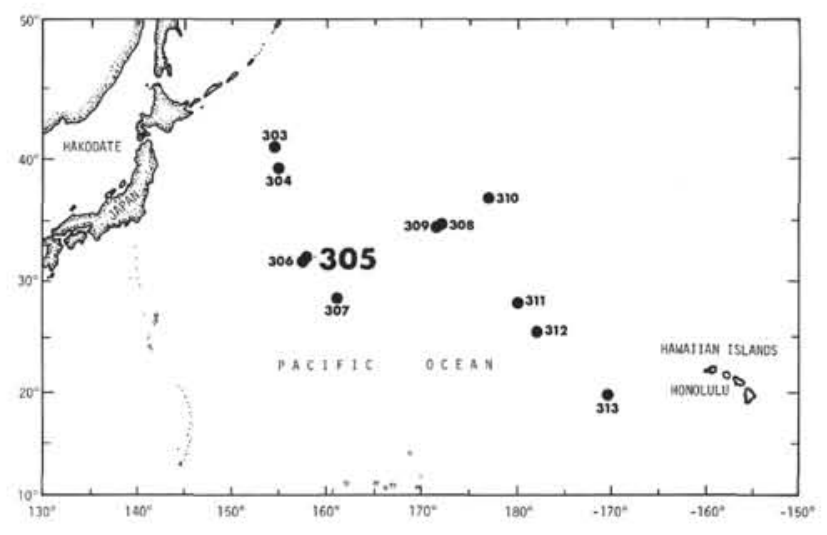

Parts of the earlier recovery on Shatsky Rise (Leg 6), as well as sites on the Ontong-Java Plateau (Legs 7 and 30), Magellan Rise (Leg 17), and various aseismic ridges and flanks of the mid-ocean ridge system have provided good material for biostratigraphy. A well-placed site on Shatsky Rise is expected to offer the best place in the deep oceans, certainly in the northern Pacific, for the recovery of a Late (or Middle?) Jurassic through Cretaceous pelagic section. Since Leg 6, the major problems of suitable bits and better dynamic positioning have been solved and Leg 32 was expected to have a heave compensation system to improve drilling techniques and lessen disturbance of cores even further. $\dot{A}$ continuously cored section from within the Paleogene down to seismic basement on Shatsky Rise is a prime objective of Leg 32. A Neogene section would be useful to paleontologists also, but less so than the deeper section. Site 305 is shown in Figure 1.

One of the chief results of the Deep Sea Drilling Project has been the identification by Leg 8 and confirmation by other DSDP Pacific legs of the Pacific plate's northward component of motion as evidenced by the successively deeper and northerly thickened sedimentary units that formed below the high productivity of the equatorial divergence. The actual sediment record and the model from plate-tectonics theory are in good agreement (Winterer, 1973; Lancelot et al., in preparation) even though refinement is highly desirable for the record older than about 40 m.y. (Clague and Jarrard, 1973). It seems almost certain that Shatsky Rise would have passed under the equator in the Mesozoic and thus would help control that earlier part of the model.

The carbonate sediment provided by fossil skeletons has been used for studies in addition to zoogeography and fossil morphology. In particular, the complex interrelationships of surface and deep-water temperature, carbon dioxide content, water depth, and general 


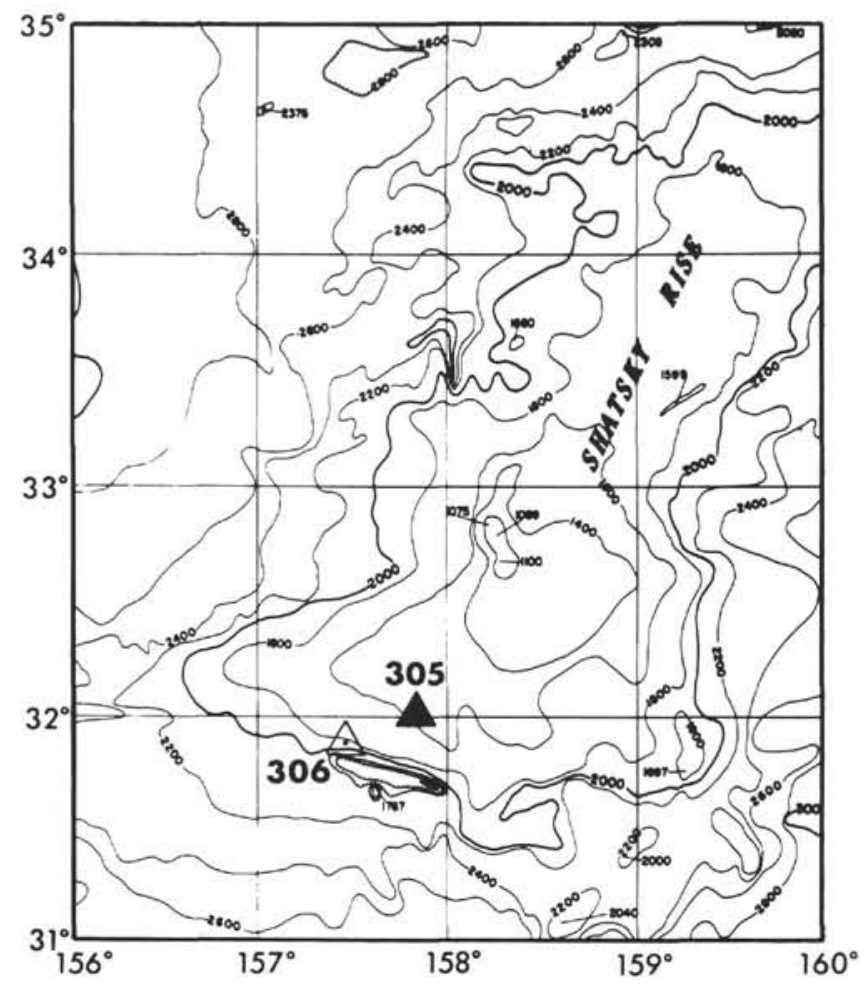

Figure 1. Bathymetry in the region of Sites 305 and 306 (after Chase et al., 1971). Contour interval $200 \mathrm{fm}$ uncorrected.

oceanic circulation may be approached through studies of the dissolution of carbonate and of ratios of oxygen isotopes, through time. Studies of calcium carbonate compensation depths (CCD) and of isotopic temperatures are more readily understood when placed in a spatial as well as temporal framework, and the carbonate sections on Shatsky and Hess rises will thereby be especially valuable.

If sufficient Mesozoic cores are obtained as planned, their study, aided by the paleooceanographic work described above, may provide insight into whether the composition of the Mesozoic ocean differed significantly from that of the Cenozoic ocean. Abundance of silica, types of cations in authigenic silicates, magnesium content of carbonates, and types of layered and framework silicates have been suggested as clues to the geochemical balance, as well as relating to such problems as intensity of weathering on land and availability of nutrients in the ocean during the Mesozoic.

Shatsky Rise is one of the elevated areas of the sea floor, including also Hess and Magellan rises and the Ontong-Java and Manihiki plateaus in the Pacific and some similar features in other oceans that are distinct from the deep sea floor and therefore are genetically different. The age and petrography, including geochemistry, of their basement rocks will be compared with that of the deep sea floor for clues as to their origin. The rises appear to form during the early history of midocean ridges where the rate of volcanism greatly exceeds the spreading rate.
Shatsky Rise is expected to provide good material for further studies of chert formation in a section of pelagic carbonate and silica. If core recovery is good, there may be primary and secondary sedimentary structures preserved which can be compared with the regional depositional stratigraphy as interpreted in the many seismic reflection records of the Shatsky area.

\section{OPERATIONS}

We approached Site 305 from the north-northwest (Figures 2 and 3 ), which provided us with a profile across the western portion of the top of Shatsky Rise (Figures 3 and 4). The most striking thing about this profile is that Shatsky Rise is capped at this location by a channel-like feature about 150 meters deep and 15-20 $\mathrm{km}$ wide that is not apparent on other profiles. Site 305 is just beyond the south edge of this feature (Figure 4) where the basement and sea floor begin to slope off the south side of the rise. Site 305 has a sediment section of about $0.75 \mathrm{sec}$ that appears to contain all the reflectors present at Site 47 of Leg 6 (approximately 0700 on 29 August, Figure 4) plus additional sediment above the first reflector.

About one-half hour before we reached the site, the computer technician reported that the dynamic positioning computer was down and that we could not receive a beacon signal. We continued to steam beyond the site to go into a "holding pattern" until the computer was repaired. One hour later the computer was fix-

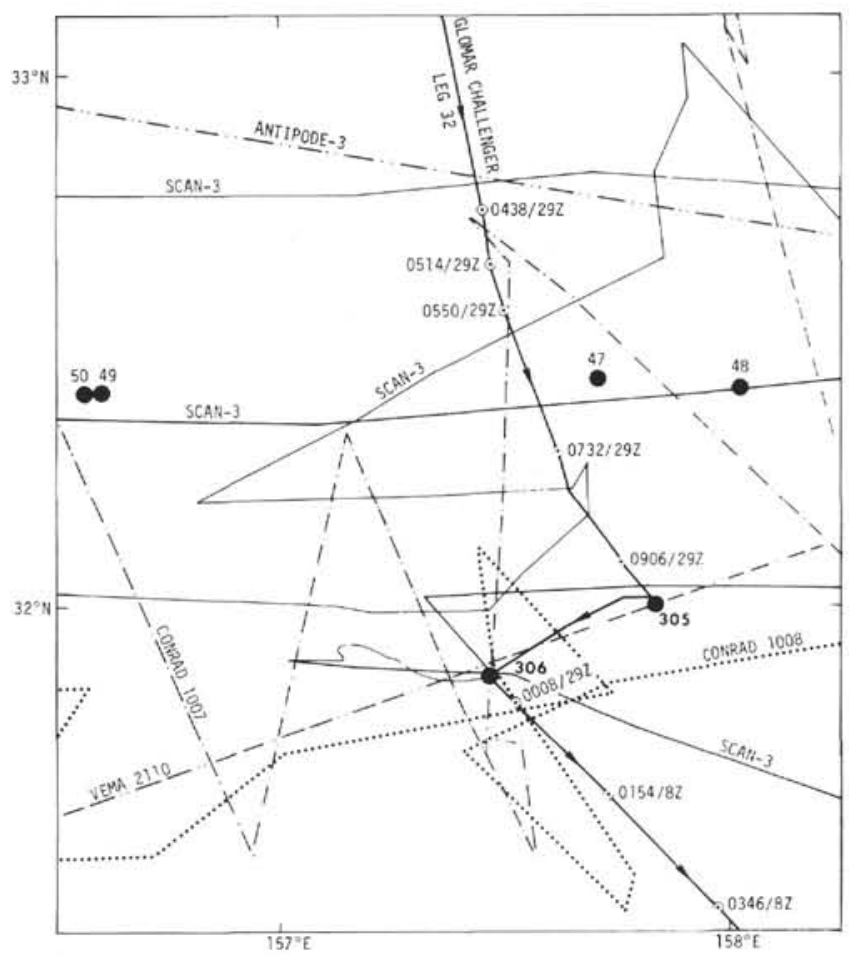

Figure 2. Track chart for Sites 305 and 306. Heavy solid track is Leg 32 Glomar Challenger, dotted track is Conrad 1008, dash-dot-dot track is Vema 2110, dash-dot track is Conrad 1007, and light solid track is Scan-3. DSDP drill sites indicated by solid circles. 


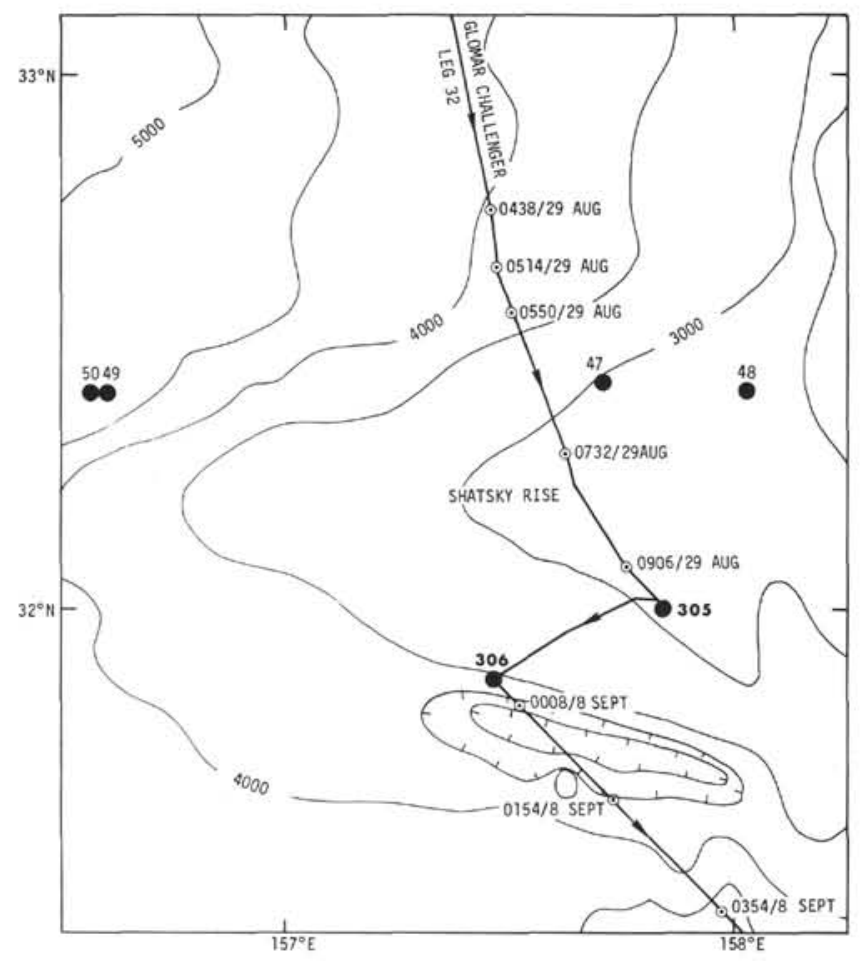

Figure 3. Bathymetry of Sites 305 and 306. Contours in corrected meters interpolated from Chase et al. (1971). Solid line marks track of Leg 32 Glomar Challenger and open circles mark navigation points with time/day-month.

ed, and we returned to the site steaming northnorthwest. We dropped a beacon at 5 knots at $1039 \mathrm{Z}$ on 29 August 1973 in 1554 uncorrected fm (= $2913 \mathrm{~m}$ corrected to the rig floor). At approximately $1100 \mathrm{Z}$ we began to run in pipe at Site 305 .
A sonobuoy was run on the last day at the site that provided about $5 \mathrm{hr}$ of excellent record of the reflections at Site 305 (Figure 5).

We left this site by steaming slowly to the eastnortheast, streaming the running gear, turning and coming back across the beacon enroute to Site 306 (Figure 4). Our route (Figures 2 and 3) from Site 305 to Site 306 was west-southwest that took us down the southwest slope of Shatsky Rise (Figure 4).

The mudline was reached about $6.5 \mathrm{hr}$ after beginning to run in pipe, somewhat ahead of the anticipated time because power tongs were used in place of the usual spinning rope to make up the pipe joints.

Recovery percentages were generally high for the upper 250 meters of the hole until cherty sediments were encountered in nearly every core from there on down. The occurrence of chert drops the recovery figures from about $80 \%$ to $100 \%$ down to less than $10 \%$ because the other sediments present with the chert are not sufficiently lithified to withstand the circulation necessary to prevent sticking the drill string and/or plugging the circulation when coring cherts. Also, large chert fragments jam in the core catcher and prevent the entry of any additional cored material.

Regardless of the poor recoveries in the Mesozoic, the sedimentation rates were such as to provide several corecatcher samples per stage which is adequate for biostratigraphic purposes. Throughout Site 305 the weather was excellent with sunny skies and very little breeze.

The last 2 meters of Core 43 (391.5-400.5 m subbottom depth) were cored without circulation in an attempt to increase recovery. This completely plugged the circulation at the bit. The attempt to recover Core 43 with the sinker bar and overshot was unsuccessful due to material on top of the core barrel at the bottom of the drill string. Another core barrel with the center bit at-

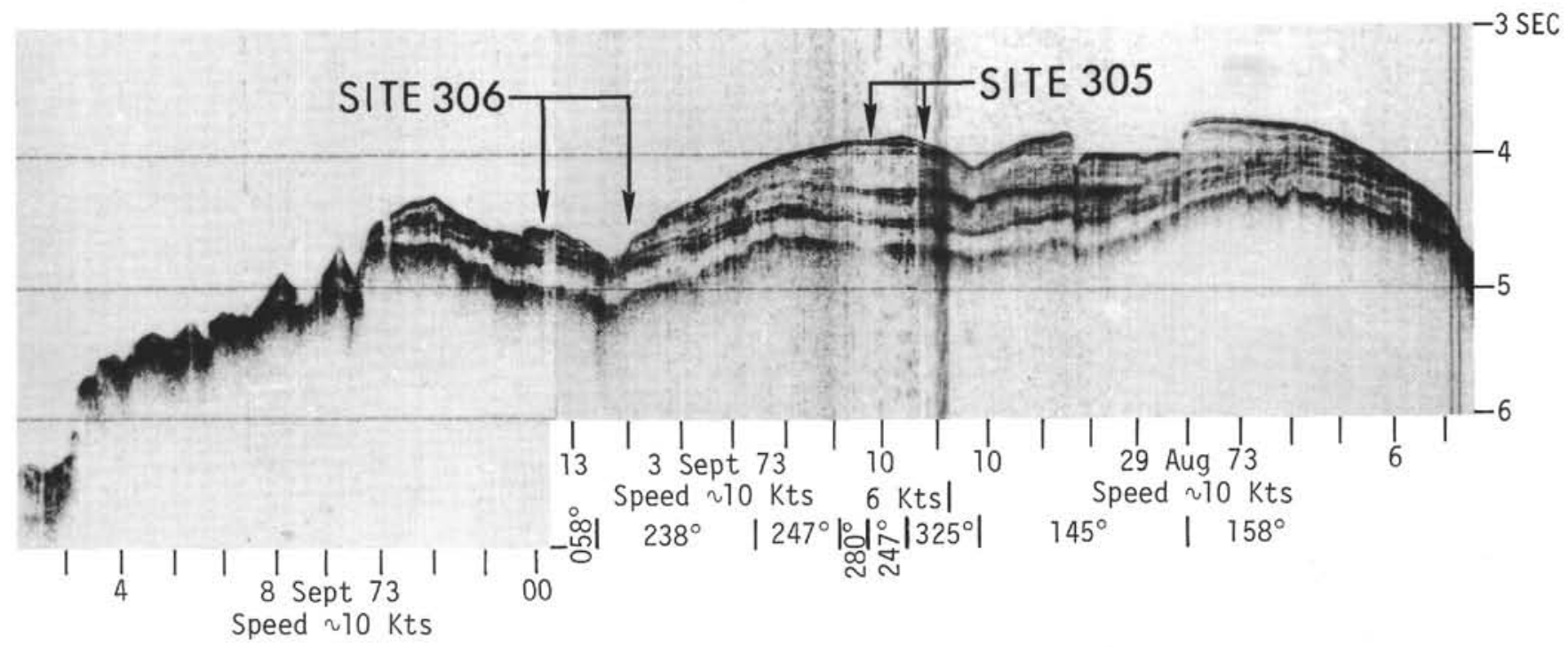

Figure 4. Seismic profiler section approaching and leaving Sites 305 and 306. 


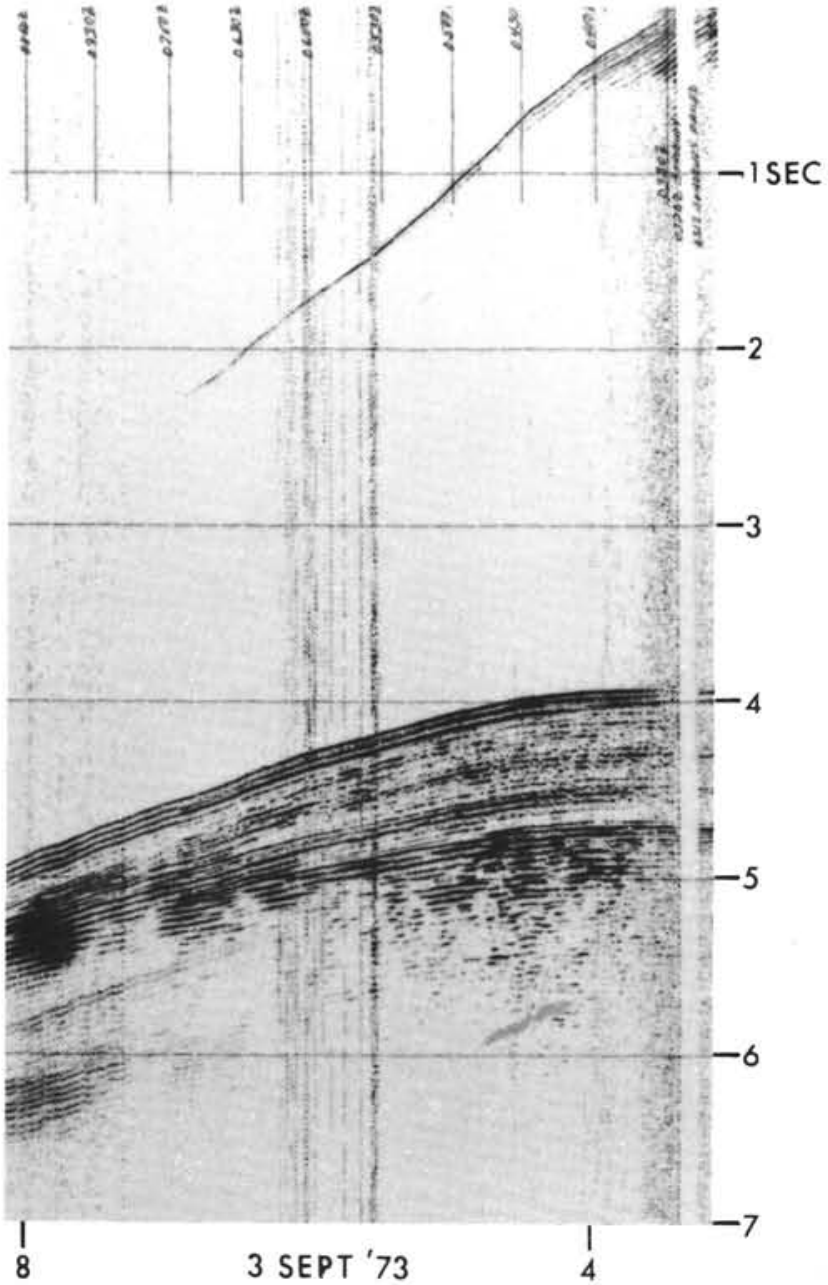

Figure 5. Sonobuoy record taken at Site 305.

tached and the check valve removed was sent falling freely down the pipe in an attempt to jam the sediment down the pipe off the top of the in-place core barrel. The center-bit core barrel was then retrieved and outfitted with a two-dog, hard-formation catcher to attempt to latch onto the in-place core barrel with the hardformation catcher. This attempt failed, the upper core barrel was retrieved, a four-dog catcher mounted, and the core barrel sent back down the pipe. Again we failed to latch on, and the retrieval of the upper core barrel in both cases indicated we were pulling it out of a considerable amount of sediment.

Approximately 200 meters of pipe were pulled out of the hole and the circulation tested. The process of pulling the pipe had partially cleared the circulation and the sediment on top of the core barrel could be flushed away. Core 43 was retrieved by standard means and found to contain 9.5 meters of back-flow chert cuttings. For the remainder of the site the hole was cleaned more often with drilling mud.

At about Core 60 the drilling started to show signs that the bit was wearing out. Cores 63 and 64 (588.5-607 m) cut extremely slowly but did not torque the string

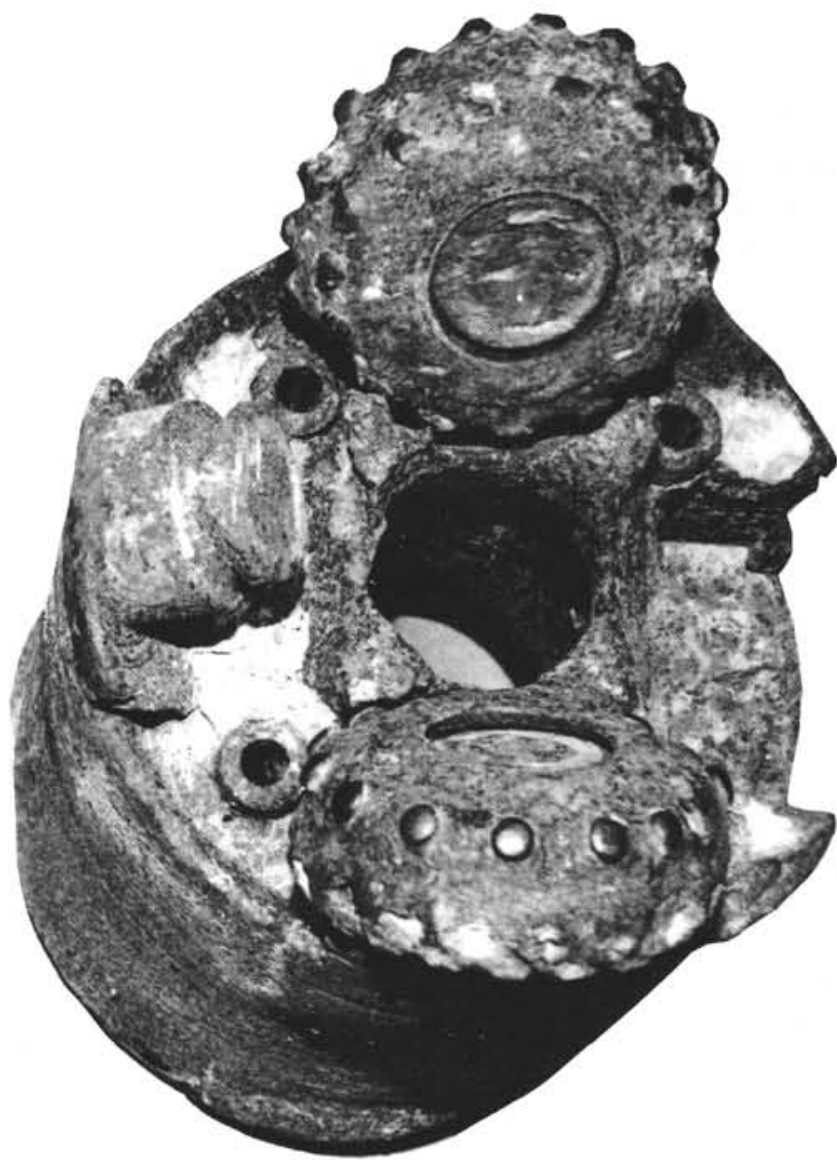

Figure 6. Drill bit recovered after termination of drilling at Site 305. Note two of the four cones are missing.

badly. This is probably the level of the lowest hard sediment reflector on the profiler record.

From 626 to 640.5 meters very high torque developed on the drill string while cutting Core 67 and especially Core 68. It was decided to abandon the hole halfway through Core 68 for fear of overheating the power sub or twisting off the drill string. The drill string was pulled up and the bit discovered to be completely used up (Figure 6). Two of the four cones were missing and the tapered portions of the remaining two cones had been worn off. The site was abandoned, and we were underway to Site 306 at $0944 Z$ on 3 September 1973. Table 1 gives a summary of the coring at Site 305 .

\section{LITHOLOGIC SUMMARY}

The sedimentary sequence of the Shatsky Rise was sampled by continuous coring to a depth of 640.5 meters, where the hole had to be abandoned due to a worn bit.

The sediments range in age from Holocene to Hauterivian and are almost exclusively composed of biogenous carbonate and silica. Small admixtures of terrigenous material, mainly clay minerals, were noted in the uppermost part of the section, and as shale beds in the lowermost part of the hole.

The major lithologic changes, the formation of chalk, limestone, and chert, are mainly the result of diagenetic 
TABLE 1

Coring Summary

\begin{tabular}{|c|c|c|c|c|c|c|c|}
\hline Core & $\begin{array}{c}\text { Date } \\
\text { (Aug.-Sept. } \\
\text { 1973) }\end{array}$ & Time & $\begin{array}{l}\text { Depth From } \\
\text { Drill Floor } \\
(\mathrm{m})\end{array}$ & $\begin{array}{l}\text { Depth Below } \\
\text { Sea Floor } \\
\text { (m) }\end{array}$ & $\begin{array}{l}\text { Length } \\
\text { Cored } \\
\text { (m) }\end{array}$ & $\begin{array}{l}\text { Length } \\
\text { Recovered } \\
\text { (m) }\end{array}$ & $\begin{array}{c}\text { Recovery } \\
\text { (\%) }\end{array}$ \\
\hline 1 & 30 & 0430 & $2921.0-2929.0$ & $0.0-8.0$ & 8.0 & 7.6 & 95 \\
\hline 2 & 30 & 0535 & $2929.0-2938.0$ & $8.0-17.0$ & 9.0 & 4.5 & 50 \\
\hline 3 & 30 & 0635 & $2938.0-2947.5$ & $17.0-26.5$ & 9.5 & 4.5 & 47 \\
\hline 4 & 30 & 0730 & $2947.5-2956.5$ & $26.5-35.5$ & 9.0 & 4.0 & 44 \\
\hline 5 & 30 & 0830 & $2956.5-2966.0$ & $35.5-45.0$ & 9.5 & 6.6 & 69 \\
\hline 6 & 30 & 0930 & $2966.0-2975.5$ & $45.0-54.5$ & 9.5 & 8.3 & 87 \\
\hline 7 & 30 & 1030 & $2975.5-2985.0$ & $54.5-64.0$ & 9.5 & 9.5 & 100 \\
\hline 8 & 30 & 1125 & $2985.0-2994.0$ & $64.0-73.0$ & 9.0 & 9.0 & 100 \\
\hline 9 & 30 & 1230 & $2994.0-3003.0$ & $73.0-82.0$ & 9.0 & 9.3 & $100+$ \\
\hline 10 & 30 & 1330 & $3003.0-3012.5$ & $82.0-91.5$ & 9.5 & 7.0 & 74 \\
\hline 11 & 30 & 1430 & $3012.5-3022.0$ & $91.5-101.0$ & 9.5 & 8.8 & 93 \\
\hline 12 & 30 & 1525 & $3022.0-3031.5$ & $101.0-110.5$ & 9.5 & 7.2 & 76 \\
\hline 13 & 30 & 1630 & $3031.5-3041.0$ & $110.5-120.0$ & 9.5 & 9.0 & 95 \\
\hline 14 & 30 & 1730 & $3041.0-3050.5$ & $120.0-129.5$ & 9.5 & 6.8 & 72 \\
\hline 15 & 30 & 1830 & $3050.5-3060.0$ & $129.5-139.0$ & 9.5 & 6.7 & 71 \\
\hline 16 & 30 & 1930 & $3060.0-3069.5$ & $139.0-148.5$ & 9.5 & 7.8 & 82 \\
\hline 17 & 30 & 2030 & $3069.5-3079.0$ & $148.5-158.0$ & 9.5 & 9.3 & 98 \\
\hline 18 & 30 & 2135 & $3079.0-3088.0$ & $158.0-167.0$ & 9.0 & 8.0 & 89 \\
\hline 19 & 30 & 2250 & $3088.0-3097.5$ & $167.0-176.5$ & 9.5 & 9.1 & 96 \\
\hline 20 & 30 & 2355 & $3097.5-3107.0$ & $176.5-186.0$ & 9.5 & 7.5 & 79 \\
\hline 21 & 31 & 0105 & $3107.0-3116.5$ & $186.0-195.5$ & 9.5 & 8.9 & 94 \\
\hline 22 & 31 & 0200 & $3116.5-3126.0$ & $195.5-205.0$ & 9.5 & tr & $<1$ \\
\hline 23 & 31 & 0315 & $3126.0-3135.0$ & $205.0-214.0$ & 9.0 & 8.8 & 98 \\
\hline 24 & 31 & 0445 & $3135.0-3144.5$ & $214.0-223.5$ & 9.5 & 7.0 & 74 \\
\hline 25 & 31 & 0550 & $3144.5-3154.0$ & $223.5-233.0$ & 9.5 & 8.0 & 84 \\
\hline 26 & 31 & 0710 & $3154.0-3163.0$ & $233.0-242.0$ & 9.0 & 6.8 & 76 \\
\hline 27 & 31 & 0820 & $3163.0-3172.5$ & $242.0-251.5$ & 9.5 & 3.0 & 32 \\
\hline 28 & 31 & 0940 & $3172.5-3182.0$ & $251.5-261.0$ & 9.5 & 4.0 & 42 \\
\hline 29 & 31 & 1115 & $3182.0-3191.5$ & $261.0-270.5$ & 9.5 & $\operatorname{tr}$ & $<1$ \\
\hline 30 & 31 & 1235 & $3191.5-3201.0$ & $270.5-280.0$ & 9.5 & $\mathrm{tr}$ & $<1$ \\
\hline 31 & 31 & 1350 & $3201.0-3210.5$ & $280.0-289.5$ & 9.5 & $\operatorname{tr}$ & $<1$ \\
\hline 32 & 31 & 1510 & $3210.5-3219.5$ & $289.5-298.5$ & 9.0 & $\operatorname{tr}$ & $<1$ \\
\hline 33 & 31 & 1620 & $3219.5-3229.0$ & $298.5-308.0$ & 9.5 & $\operatorname{tr}$ & $<1$ \\
\hline 34 & 31 & 1730 & $3229.0-3238.5$ & $308.0-317.5$ & 9.5 & 0.2 & 2 \\
\hline 35 & 31 & 1900 & $3238.5-3247.5$ & $317.5-326.5$ & 9.0 & 0.3 & 3 \\
\hline 36 & 31 & 2025 & $3247.5-3257.0$ & $326.5-336.0$ & 9.5 & 0.4 & 4 \\
\hline 37 & 31 & 2155 & $3257.0-3266.5$ & $336.0-345.5$ & 9.5 & 0.4 & 4 \\
\hline \multirow[t]{2}{*}{38} & 31 & 2315 & $3266.5-3275.5$ & $345.5-354.5$ & 9.0 & 0.2 & 2 \\
\hline & Sept. & & & & & & \\
\hline 39 & 1 & 0045 & $3275.5-3285.0$ & $354.5-364.0$ & 9.5 & 0.2 & 2 \\
\hline 40 & 1 & 0155 & $3285.0-3294.5$ & $364.0-373.5$ & 9.5 & 0.1 & 1 \\
\hline 41 & 1 & 0330 & $3294.5-3303.5$ & $373.5-382.5$ & 9.0 & 0.1 & 1 \\
\hline 42 & 1 & 0450 & $3303.5-3312.5$ & $382.5-391.5$ & 9.0 & 0.5 & 6 \\
\hline 43 & 1 & 1150 & $3312.5-3321.5$ & $391.5-400.5$ & 9.0 & 3.6 & 40 \\
\hline 44 & 1 & 1620 & $3331.0-3340.0$ & $410.0-419.0$ & 9.0 & 0.2 & 2 \\
\hline 45 & 1 & 1945 & $3340.0-3349.5$ & $419.0-428.5$ & 9.5 & 0.1 & 1 \\
\hline 46 & 1 & 2135 & $3349.5-3359.0$ & $428.5-438.0$ & 9.5 & 0.2 & 2 \\
\hline 47 & 1 & 2255 & $3359.0-3368.5$ & $438.0-447.5$ & 9.5 & 0.7 & 7 \\
\hline 48 & 2 & 0045 & $3368.5-3377.5$ & $447.5-456.5$ & 9.0 & 0.1 & 1 \\
\hline 49 & 2 & 0235 & $3377.5-3387.0$ & $456.5-466.0$ & 9.5 & $\mathrm{tr}$ & $<1$ \\
\hline 50 & 2 & 0350 & $3387.0-3396.5$ & $466.0-475.5$ & 9.5 & tr & $<1$ \\
\hline 51 & 2 & 0510 & $3396.5-3405.5$ & $475.5-484.5$ & 9.0 & 0.1 & 1 \\
\hline 52 & 2 & 0640 & $3405.5-3415.0$ & $484.5-494.0$ & 9.5 & 0.1 & 1 \\
\hline 53 & 2 & 0820 & $3415.0-3424.5$ & $494.0-503.5$ & 9.5 & 0.1 & 1 \\
\hline 54 & 2 & 0950 & $3424.5-3434.0$ & $503.5-513.0$ & 9.5 & 0.2 & 2 \\
\hline 55 & 2 & 1115 & $3434.0-3443.0$ & $513.0-522.0$ & 9.0 & 0.1 & 1 \\
\hline 56 & 2 & 1230 & $3443.0-3452.5$ & $522.0-531.5$ & 9.5 & 0.3 & 3 \\
\hline 57 & 2 & 1410 & $3452.5-3462.0$ & $531.5-541.0$ & 9.5 & 0.3 & 3 \\
\hline 58 & 2 & 1545 & $3462.0-3471.5$ & $541.0-550.5$ & 9.5 & 0.4 & 4 \\
\hline 59 & 2 & 1730 & $3471.5-3481.0$ & $550.5-560.0$ & 9.5 & 0.5 & 5 \\
\hline 60 & 2 & 1940 & $3481.0-3490.5$ & $560.0-569.5$ & 9.5 & 0.7 & 7 \\
\hline 61 & 2 & 2130 & $3490.5-3500.0$ & $569.5-579.0$ & 9.5 & 0.4 & 4 \\
\hline 62 & 2 & 2255 & $3500.0-3509.5$ & $579.0-588.5$ & 9.5 & 0.1 & 1 \\
\hline 63 & 3 & 0055 & $3509.5-3519.0$ & $588.5-598.0$ & 9.5 & 0.8 & 8 \\
\hline 64 & 3 & 0340 & $3519.0-3528.0$ & $598.0-607.0$ & 9.0 & 0.5 & 5 \\
\hline 65 & 3 & 0620 & $3528.0-3537.5$ & $607.0-616.5$ & 9.5 & 1.0 & 11 \\
\hline 66 & 3 & 0800 & $3537.5-3547.0$ & $616.5-626.0$ & 9.5 & 0.7 & 7 \\
\hline 67 & 3 & 0930 & $3547.0-3556.5$ & $626.0-635.5$ & 9.5 & tr & 1 \\
\hline 68 & 3 & 1035 & $3556.5-3561.5$ & $635.5-640.5$ & 5.0 & $\mathrm{tr}$ & 1 \\
\hline Total & & & & & 631.0 & 210.6 & 33.4 \\
\hline
\end{tabular}


processes. The first chert occurs in Core 17 at 152 meters and chert is abundant throughout the remainder of the cored section. With increasing overburden and age, the soft oozes have been gradually altered to chalk and, in the lowermost part of the sequence, to porous limestone.

The composition of the sediments is shown in the smear slide summary (Table 2). Its accuracy was improved by checking the visual estimates against carbon carbonate and X-ray data.

The following four lithologic units are recognized:

Unit 1-Siliceous foram-bearing nanno ooze $(0-52 \mathrm{~m}$, Cores 1 to 6 , Section 5.).

Unit 2-Foram nanno ooze (52-148.5 m, Core 6, Section 5 to Core 16 ).

Unit 3-Foram-bearing nanno ooze, chalk, and chert (14.8.5-541 m, Cores 17 to 57$)$.

Unit 4-Radiolarian nanno limestone, porcellanite, and chert (541-640.5 m, Cores 58 to 68 ).

\section{Unit 1-Siliceous Foram-bearing Nanno Ooze (Cores 1 through 6, Section 5)}

The major part of this unit is composed of $50 \%$ to $60 \%$ nannofossils, $10 \%$ to $20 \%$ foraminfers, $5 \%$ to $15 \%$ diatoms, up to $5 \%$ Radiolaria, rare silicoflagellates, sponge spicules, light-colored volcanic glass shards, and a few percent quartz, feldspar, and clay minerals. The total terrigenous component varies between $1 \%$ and $10 \%$. The calcium carbonate content ranges between $60 \%$ and $70 \%$ (Table 3 ), whereas the organic carbon content stays consistently at $0.1 \%$.

A more calcareous interval was recovered with Cores 3 and 4 which contain about $90 \%$ calcareous microfossils.

Small pumice fragments occur at various levels in this unit.

Because of severe drilling disturbance, primary sedimentary structures in the soft oozes were usually destroyed. Nevertheless, several graded beds, about 30 $\mathrm{cm}$ thick, are found in Cores 1 and 2.

The sediment color ranges from dominantly pale orange to yellow-brown.

\section{Unit 2-Foram Nanno Ooze (Cores 6, Section 5 through Core 16)}

The sediments of Unit 2, which comprises the late Maestrichtian and the whole Paleogene, differ from those of the overlying Unit 1 by the absence of siliceous fossils. The siliceous fossils decrease in abundance markedly at the Pliocene/Miocene boundary at about 40 meters and disappear completely below 52 meters (they reappear in the Mesozoic). This is also shown as an increase of the calcium carbonate content from about $80 \%$ to $95 \%$ at the same depth. The megascopic examination, however, does not reveal any lithologic break, so the unit boundaries are taken solely on the basis of the compositional change mentioned above.

Unit 2 consists of a monotonous sequence of dominantly very pale orange to occasionally yellowbrown soft, pure foraminiferal nanno oozes. Tests of nannofossils (70\% to $90 \%$ ) and of foraminifera (less than $5 \%$ to $25 \%$ ) are the major constituents.

The calcium carbonate content averages $95 \%$, and terrigenous minerals are virtually absent. Small amounts of phillipsite (trace to $2 \%$ ), micron-sized brown volcanic glass and tiny amorphous(?) ferromanganese particles and some clay minerals make up the remaining $5 \%$. The ferromanganese oxides cause the light orange color of these oozes. The clay size fraction always contains $10 \%$ to $20 \%$ palygorskite which is absent in Unit 1 .

Phillipsite occurs as slender twinned and untwinned prisms 20 to $150 \mu \mathrm{m}$ long. Larger crystals frequently show zonation. Badly corroded crystals were observed in many samples.

The preservation of the microfossils is moderate to poor, due to dissolution.

No organic carbon was detected in Units 2 to 4, except in a few shale beds at the bottom of the hole.

\section{Unit 3-Foram-Bearing Nanno Ooze, Chalk, and Chert (Cores 17 through 57)}

The upper limit of this unit is taken by the first occurrence of chalk and chert. Below Core $26(242 \mathrm{~m})$, recovery was very poor; generally only core-catcher samples containing chert and occasionally small chalk fragments were retrieved. During the drilling process the weakly consolidated chalk is frequently ground up to soft ooze which is often washed away. This means that only the hardest sediment types encountered are sampled, and consequently a reconstruction of the lithologic sequence is almost impossible. The sequence most likely consists of chalk and chert interbeds or nodules of unknown relative proportions. The color of the chalk changes from pale orange to white below Core 28 (261 $\mathrm{m})$.

The chalk is made up of $96 \%$ to $98 \%$ carbonate. The proportions of foraminifera and nannofossils vary considerably; from foram-bearing nanno chalks with $10 \%$ to $25 \%$ foraminifera versus $70 \%$ to $85 \%$ nannofossils and foram-nanno chalks with $30 \%$ to $40 \%$ foraminifera versus $50 \%$ to $60 \%$ nannofossils. Almost all samples contain a trace to $2 \%$ echinoid spines. Rare Radiolaria occur below Core 39 .

Toward the base of the unit the chalk gets gradually harder. The increasing lithification due to silicification and recrystallization of nannofossils (Matter et al., this volume) is also seen in the smear slides by the presence of large amounts of structureless carbonate particles ranging from a few micrometers to $10 \mu \mathrm{m}$ in size.

Recrystallized silica is observed in many smear slides of samples from the lower part of Unit 3. Partly it comes from the chert pieces of which the chalk crusts had to be scraped off, but partly it occurs in radiolarian foram chalks. The latter are semilithified with almost all of the opal-A of the original radiolarian tests replaced by clear chalcedony and to a lesser extent also replaced by opalCT (Jones and Segnit, 1971). These mineral also fill the chambers and may partly replace walls of foraminifera.

Silicification by opal-CT has also affected the nannofossil matrix of these radiolarian-foram limestones (Core 47, Section 1 at $128 \mathrm{~cm}$ ) in a patchy manner. These radiolarian-foram limestones also contain scattered dolomite rhombs.

Chert is present in small amounts as thin irregular layers and displaced pieces in the upper part of the unit, but its proportion increases with depth. The chert is massive, hard, conchoidally fractured, and colored from 
TABLE 2

Smear Slide Summary, Site 305

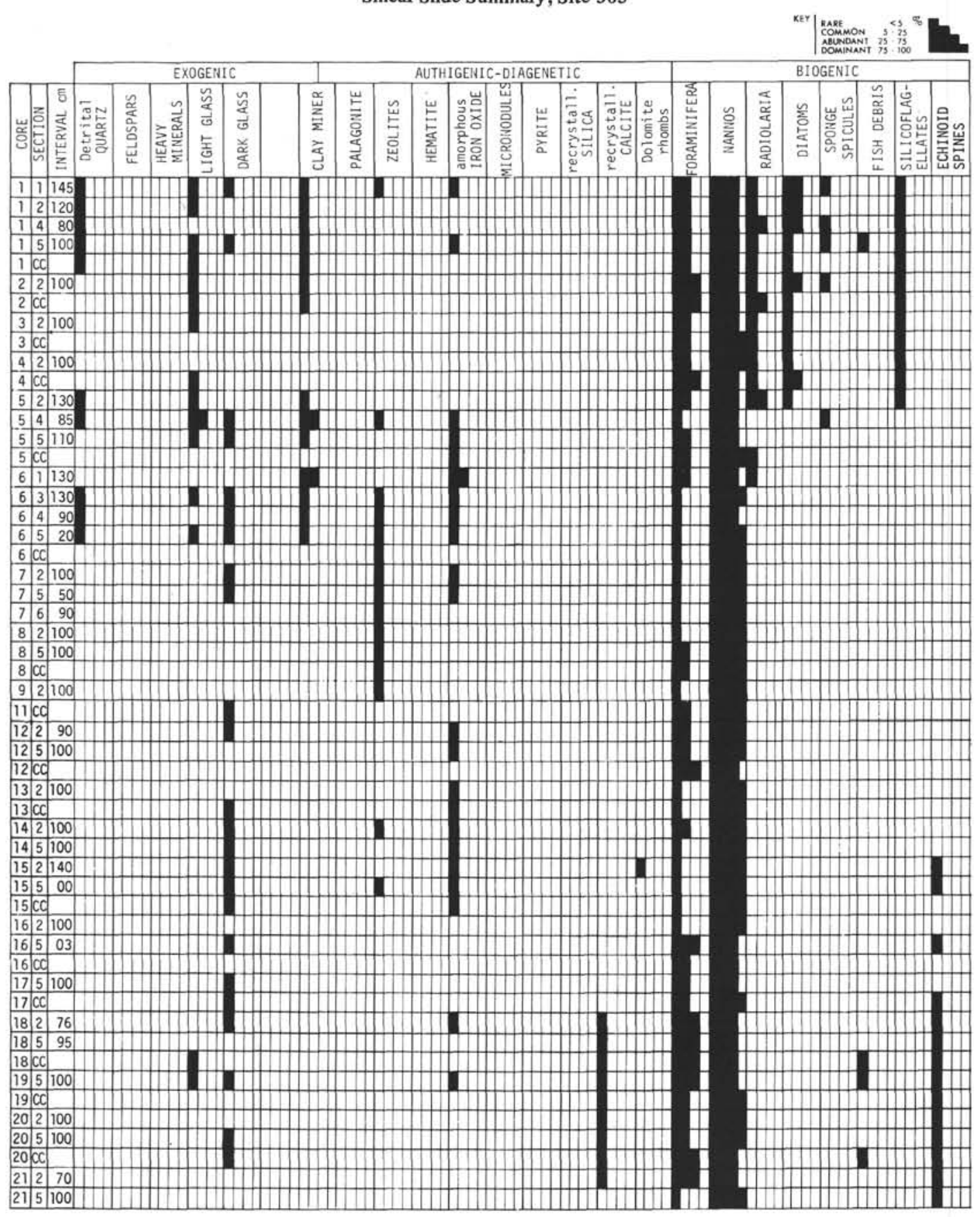




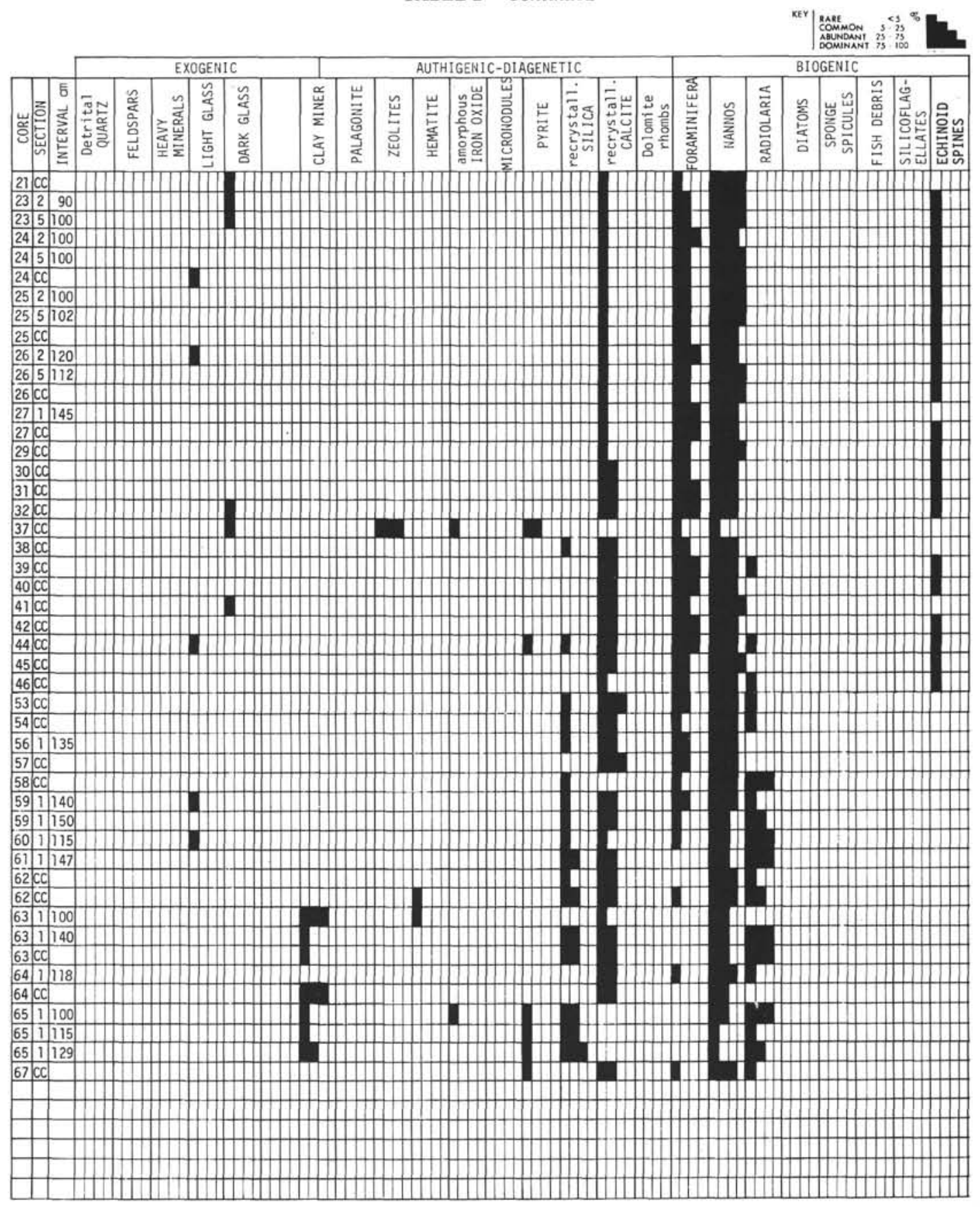


TABLE 3

Additional Carbon-Carbonate Data

\begin{tabular}{ccc}
\hline Sample & $\begin{array}{c}\text { Hole Depth } \\
(\mathrm{m})\end{array}$ & $\begin{array}{c}\mathrm{CaCO}_{3} \\
(\%)\end{array}$ \\
\hline $1-2,20$ & 1.70 & 60 \\
$1-6,140$ & 8.90 & 79 \\
$2-3,30$ & 11.30 & 84 \\
$4-3,40$ & 29.90 & 90 \\
$5-3,50$ & 39.0 & 80 \\
$6-4,92$ & 50.42 & 74 \\
$6-5,135$ & 52.35 & 95 \\
$7-4,100$ & 60.00 & 96 \\
$7-5,60$ & 61.10 & 93 \\
$9-3,100$ & 77.0 & 96 \\
$10-3,130$ & 86.3 & 97 \\
$25-3,47$ & 226.97 & 76 \\
$44, \mathrm{CC}$ & 419.0 & 57 \\
$46, \mathrm{CC}$ & 438.0 & 89 \\
$59-1,140$ & 551.9 & 86 \\
$61-1,135$ & 570.85 & 33 \\
$64-1,100$ & 599.0 & 88 \\
$66-1,136$ & 617.86 & 0 \\
\hline
\end{tabular}

Note: Analytical method: Gasvolumetric with Scheibler apparatus.

dark gray to brown. It is commonly inhomogeneous with lighter irregular blebs and diffuse layers and also contains flat vugs less than $2 \mathrm{~cm}$ in size. It is impure and consists of a very fine-grained mosaic of microquartz, scattered tiny calcite crystals, and radiolarian ghosts. Some radiolarian molds which appear clear in thin section are filled with fibrous chalcedony. The ferruginous (brown) chert shows irregular concentrations with diffuse boundaries of hematite particles. The chert pieces are almost always covered with thin, partly silicified white chalk crusts which also line the vugs.

Unit 4-Radiolarian Nanno Limestone, Porcellanite, and Chert (Cores 58 through 68)

The gradational boundary between Units 3 and 4 is marked by the gradual appearance of Radiolaria. Recovery slightly improved in the latter unit, but was still poor.

The dominant lithologies are porous Radiolaria nanno limestones and radiolarian cherts. The admixture of abundant clay minerals in the lower half of the unit leads to various other lithologies, such as dark greenishgray pelagic claystone, gray carbonaceous pelagic shale, light gray laminated or massive porcellanites, and brown nanno pelagic shale. Less commonly, dominantly white limestones with irregular wavy lamination and moderate bioturbation were also encountered. Fucoidlike burrows are present in Core 64 .

Thin sections of the foram-bearing radiolarian nanno limestones show advanced recrystallization. Chambers of the foraminifera tests are filled with coarse sparry calcite.

Radiolaria occurring in limestones are generally replaced by clear chalcedony. However, partly calcitized radiolarian tests were noticed as well.

The radiolarian molds in a limestone from Sample 58, $\mathrm{CC}$ are rimmed with clear, merging, half-spheres each of which is composed of fibrous chalcedony, yet the remaining inner void space is now filled with brownish fibrous disordered cristobalite.

The contact of the radiolarian limestones with the irregularly shaped chert masses is generally sharp with a transitional zone up to a few millimeters.

Unit 4 has a lower proportion of chert than Unit 3, and the chert becomes more like a porcellanite. The chert is generally pinkish-gray to brownish-gray in color. Faint laminations and subhorizontal fractures now filled with chalcedony are commonly present.

True porcellanites with dull luster, lower density, and abundant clay minerals were recovered in the lowermost three cores, as well as gray carbonaceous radiolarian porcellanites that contain up to $9 \%$ organic carbon and up to $3 \%$ pyrite. These porcellanites are silicified with faintly fibrous microquartz and opal-CT, and contain phillipsite and barite. Barite was also noted in silicified radiolarian limestones.

\section{GEOCHEMICAL MEASUREMENTS}

Alkalinity, $p \mathrm{H}$, and salinity measurements for Site 305 are summarized in Table 4 and presented graphically in Figure 7. The sediments were squeezed at $4^{\circ} \mathrm{C}$ to obtain the interstitial water. Seven interstitial water samples down to 239 meters (depth subbottom) were collected before the sediment became lithified and recovery decreased.

\section{Alkalinity}

Alkalinity reaches a maximum measured value of 3.03 $\mathrm{meq} / \mathrm{kg}$ at 52.5 meters and then decreases gradually with depth to $2.48 \mathrm{meq} / \mathrm{kg}$ at 146.5 meters. It then remains relatively constant down to 239.0 meters. The entire section sampled was carbonate ooze and the values obtained are typical for this type of sediment.

pH

The $p \mathrm{H}$ of the interstitial water is less than seawater for all samples and remains fairly constant with depth. Using the punch-in method it varies from 7.54 to 7.70 .

\section{Salinity}

The salinity of the interstitial water ranges from the surface seawater value to $34.9 \%$ to $35.8 \%$ oo.

\section{Carbonate Content}

Table 5 presents the results of eight analyses for calcium carbonate in the sediment. The results vary from $91 \%$ to $96 \% \mathrm{CaCO}_{3}$.

\section{PHYSICAL PROPERTIES}

\section{Wet Bulk Density and Porosity of Soft Sediments}

The wet bulk density of the soft-stiff, moderately intensely disturbed sediments recovered at Site 305 was measured with the gamma-ray attenuation porosity evaluator (GRAPE). Because of the large volume of sediments, only Sections 2 and 5 from each core were measured. The density increases with minor fluctuations from about $1.60 \mathrm{~g} / \mathrm{cc}$ in Core 1 to about 1.80 in Core 11 $(100 \mathrm{~m})$ and remains fairly constant down to the last sediments measured (Core 26, $240 \mathrm{~m}$ ). Syringe samples 
TABLE 4

Summary of Shipboard Geochemical Data

\begin{tabular}{lcccccc}
\hline $\begin{array}{c}\text { Sample } \\
\text { Interval } \\
\text { in cm) }\end{array}$ & $\begin{array}{c}\text { Depth Below } \\
\text { Sea Floor }(\mathrm{m})\end{array}$ & $\begin{array}{c}\text { Punch- } \\
\text { in }\end{array}$ & $\begin{array}{c}\text { Flow- } \\
\text { through }\end{array}$ & $\begin{array}{c}\text { Alkalinity } \\
(\mathrm{meq} / \mathrm{kg})\end{array}$ & $\begin{array}{c}\text { Salinity } \\
(\% / \%)\end{array}$ & Remarks \\
\hline Surface Seawater & & 8.30 & 8.28 & 2.29 & 34.9 & 8.27 \\
$1-5,144-150$ & 7.5 & 7.70 & 7.73 & 2.34 & 34.9 & 7.72 \\
$3-2,144-150$ & 20.0 & 7.63 & 7.72 & 2.30 & 35.2 & 7.69 \\
$6-5,144-150$ & 52.5 & 7.68 & 7.43 & 3.03 & 35.5 & 7.55 \\
$11-5,144-150$ & 99.0 & 7.54 & 7.42 & 2.83 & 35.2 & 7.52 \\
$16-5,144-150$ & 146.5 & 7.60 & 7.45 & 2.48 & 35.8 & 7.61 \\
$21-4,144-150$ & 192.0 & 7.55 & 7.56 & 2.48 & 35.5 & 7.60 \\
$26-4,144-150$ & 239.0 & 7.65 & 7.49 & 2.49 & 35.5 & 7.57 \\
\hline
\end{tabular}

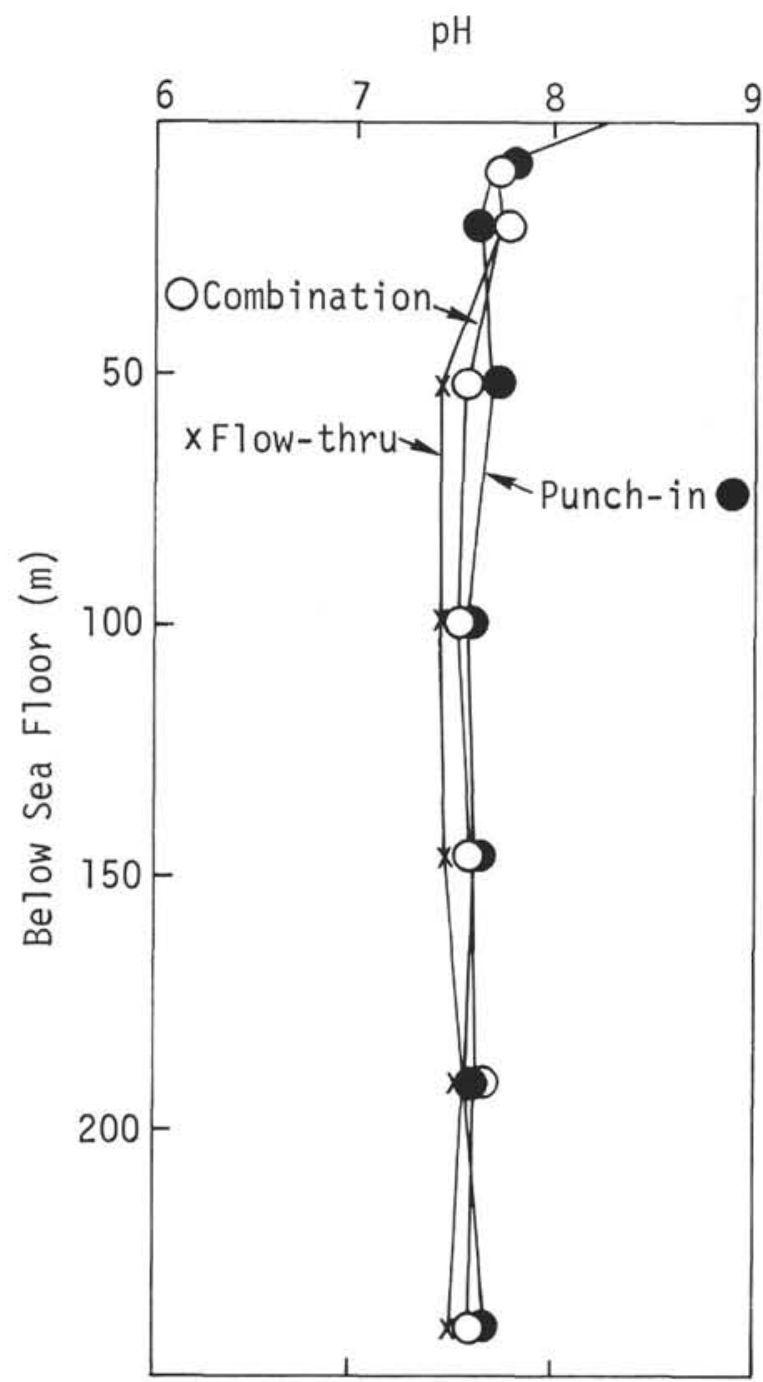

$$
\text { Alkalinity (meq/ } / \mathrm{kg} \text { ) }
$$$$
\text { Salinity }(\% \circ)
$$
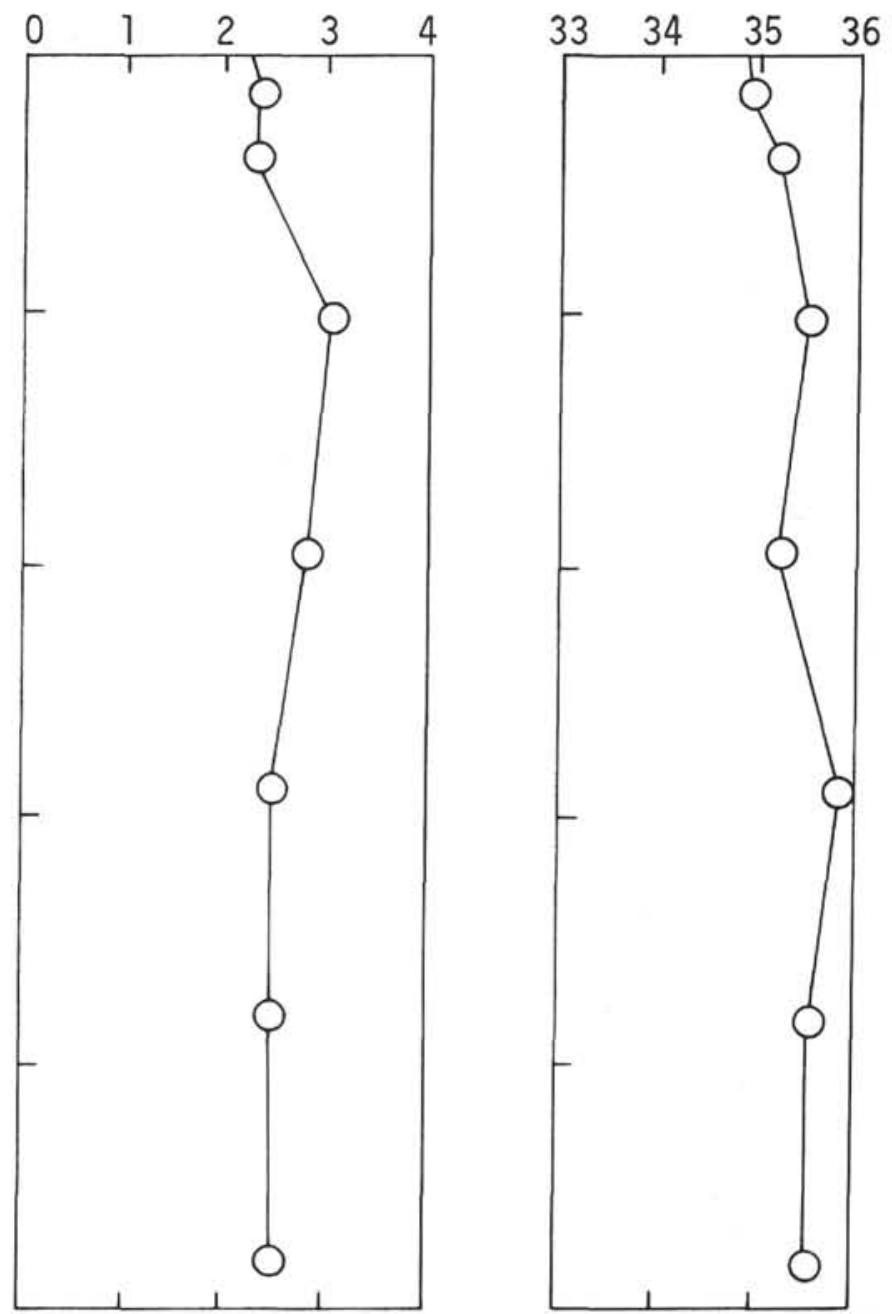

Figure 7. Graphic summary of geochemical data taken at Site 305.

were also taken from Sections 2 and 5 of each cores as an independent measure of bulk density and porosity. The bulk density as measured by the syringe shows the same variation with depth as that obtained by the GRAPE. The densities agree within several percent of the GRAPE values. The density of the calcareous oozes at this site $(1.6-1.8 \mathrm{~g} / \mathrm{cc})$ is noticeably higher than that of the siliceous oozes $(1.3 \mathrm{~g} / \mathrm{cc})$ from Sites 303 and 304 . The porosity of the calcareous oozes decreased from $65 \%$ near the top to about $55 \%, 240$ meters below the sediment-water interface. These porosity values are noticeably lower than that $(\sim 85 \%)$ of the siliceous oozes. The higher density of the calcareous oozes is due largely to their lower porosity. 
TABLE 5

$\% \mathrm{CaCO}_{3}$ - "Carbonate Bomb" Method Shipboard Measurement

\begin{tabular}{|c|c|c|c|}
\hline $\begin{array}{c}\text { Sample } \\
\text { (Interval in } \mathrm{cm} \text { ) }\end{array}$ & Weight (g) & Pressure & $\begin{array}{c}\mathrm{CaCO}_{3} \\
(\%)\end{array}$ \\
\hline $8-2,100-102$ & 0.92 & 1.42 & $94 \%$ \\
\hline $9-5,100-102$ & 0.94 & 1.40 & $91 \%$ \\
\hline $13-2,103-105$ & 0.97 & 1.47 & $93 \%$ \\
\hline $16-2,103-105$ & 0.96 & 1.49 & $95 \%$ \\
\hline $16-5,3-5$ & 0.98 & 1.53 & $96 \%$ \\
\hline $17-5,101-103$ & 0.97 & 1.51 & $96 \%$ \\
\hline $20-5,105-107$ & 0.94 & 1.41 & $92 \%$ \\
\hline $26-2,120$ & 0.97 & 1.49 & $94 \%$ \\
\hline
\end{tabular}

\section{Velocity Measurements}

The compressional wave velocity, $V p$, of the calcareous oozes and rocks was measured with a Hamilton frame. The $V p$ of the oozes was measured on the split cores, and that of the more lithified rocks was measured on fragments and core segments. The $V p$ of the soft-stiff, moderately intensely disturbed calcareous ooze increases from about $1.52 \mathrm{~km} / \mathrm{sec}$ at the top of the sediments to about $1.57 \mathrm{~km} / \mathrm{sec}$ at 240 meters below the water-sediment interface. The $V p$ of the calcareous ooze is quite similar to that of the siliceous ooze at Sites 303 and 304. The $V p$ of the semilithified limestones recovered near the bottom of this hole ranges from 2 to $3 \mathrm{~km} / \mathrm{sec}$. The carbonaceous and calcareous pelagic claystones have a $V p$ of 2.7 to $3.2 \mathrm{~km} / \mathrm{sec}$. The wellsilicified cherts recovered throughout much of this section have a $V p$ of $4.4-5.4 \mathrm{~km} / \mathrm{sec}$.

The physical property measurements are summarized graphically in Table 6.

\section{CORRELATION OF SEISMIC REFLECTION PROFILES WITH DRILLING RESULTS}

Seismic reflection profiles recorded while approaching and leaving (Figure 4) Site 305 show a thick $(0.77 \mathrm{sec})$, moderately stratified section overlying the acoustic basement. Within this section two discrete sharp reflectors can be observed, at 0.36 and $0.58 \mathrm{sec}$ below the sea floor, respectively.

Due to the very poor recovery in cores from depths below the upper 150 meters of sediment, correlation of the lithology with the "acoustic stratigraphy" remains somewhat uncertain. The first (upper) reflector at 0.36 sec below the sea floor is believed to correspond with the first abundant chert encountered at about 300 meters. Some chert fragments have been recovered in the overlying sediments, but the chert nodules or layers were probably too scattered and too thin to produce any reflection. The first massive chert corresponds also with a substantial decrease in the drilling rate and with a marked decrease in the core recovery. The interval velocity computed for the uppermost interval is about $1.65 \mathrm{~km} / \mathrm{sec}$, which seems a little low as the lower half of the interval is believed to contain substantial amounts of chalk and chert, although most of the chalk was rather soft and chert was rare except in the lowermost 40 meters of the interval.
The second reflector, at $0.58 \mathrm{sec}$ below the sea floor, probably corresponds with the top of the porcellanite and chert section observed at the base of the hole. Apparently most of this lowermost section consists of hard chert nodules and/or layers interbedded with welllithified calcareous porcellanite. The top of this interval corresponds also with a marked decrease in the drilling rate at about 610 meters. The velocity computed for the interval between the two reflectors reaches $2.8 \mathrm{~km} / \mathrm{sec}$, a value comparable to that observed previously in the chert-rich sections of Sites 303 and 304.

As basement was not reached by the drill, it is impossible to determine the sound velocity in the interval between the second reflector and the acoustic basement which is probably the top of the basalt. This velocity is almost certainly above $2.8 \mathrm{~km} / \mathrm{sec}$ and might reach 3.1 $\mathrm{km} / \mathrm{sec}$ or more. Therefore the basement lies at least as deep as $\mathbf{2 7 0}$ meters and possibly as deep as $\mathbf{3 0 0}$ meters or more below the second reflector. The total sedimentary section can then be estimated as 880 to 910 meters thick and the basalt probably lies at 240 to 270 meters below the level reached in the last core at Site 305.

Figure 8 summarizes the correlation described above.

\section{BIOSTRATIGRAPHIC SUMMARY}

\section{Cenozoic}

A 130-meter section of Cenozoic sediment (Cores 114) is characterized by abundant, poorly preserved foraminifers and abundant, moderately to poorly preserved (overgrown) coccoliths. Radiolaria are well preserved, but occur only in Neogene Cores 1 to 5 (0-45 $\mathrm{m})$. Diatoms are rare and poorly preserved in Cores 1 to $4(0-36 \mathrm{~m})$. Biostratigraphic zonation and age determinations are shown in the Graphic Hole Summary.

The Mesozoic-Cenozoic boundary occurs between Cores 14 and 15 at 130 meters. The early Paleocene Globorotalia trinidadensis Zone of foraminifers is identified from the bottom of Core 14 core-catcher sample, the late Maestrichtian Micula mura Zone of coccoliths from the top of Core 15. Strong dissolution is indicated in the vicinity of the boundary.

\section{Mesozoic}

A 511-meter section of Mesozoic sediment (Cores 1568) ranges in age from Valanginian or Hauterivian to late Maestrichtian. Foraminifers furnish the most consistent biostratigraphic criteria through the section. Below Campanian Core 28, sediment recoveries are mainly limited to small core-catcher samples of chert and firm chalks. Less-consolidated intervals, where calcareous microfossils would be better preserved, were not retrieved due to the high pumping pressure needed to clear chert cuttings from the bit. Coccoliths are abundant but typically poorly preserved and provide only broad age assignments for most samples. Like coccoliths, Radiolaria provide broad age assignments and vary in preservation and abundance. In contrast to Sites 303 and 304, Radiolaria are better preserved in calcareous sediment at Site 305 than in chert.

A short interval of black bituminous shale in Core 37 (336-346 m) is dated as early Cenomanian based on the foraminifers Rotalipora greenhornensis and $R$. gandolfii. 
TABLE 6

Distribution, Age, and Frequency of Investigated Microfossils

\begin{tabular}{|c|c|c|c|c|c|c|c|c|c|}
\hline \multirow{2}{*}{ రัँ } & \multirow[b]{2}{*}{ Depth (m) } & \multirow{2}{*}{ 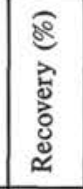 } & \multicolumn{3}{|c|}{ Foraminifera } & \multirow{2}{*}{\multicolumn{2}{|c|}{$\begin{array}{c}\text { Calcareous } \\
\text { Nannoplankton }\end{array}$}} & \multirow{2}{*}{\multicolumn{2}{|c|}{ Radiolaria }} \\
\hline & & & 율 & 巴ే & & & & & \\
\hline 1 & $0.0-8.0$ & 95 & $\bullet$ & * & Quaternary & $\bullet$ & Quaternary & o & Pleistocene \\
\hline 2 & $8.0-17.0$ & 50 & - & * & Quaternary & - & $\begin{array}{l}\text { Late Pliocene } \\
\text { (top Quaternary) }\end{array}$ & o & Pliocene? \\
\hline 3 & $17.0-26.5$ & 47 & $\bullet$ & $*$ & Pliocene & - & Late Pliocene & o & $\begin{array}{l}\text { Early Pliocene/ } \\
\text { late Miocene }\end{array}$ \\
\hline 4 & $26.5-35.5$ & 44 & $\bullet$ & $*$ & Pliocene & $\bullet$ & Late Pliocene & 0 & $\begin{array}{l}\text { Early Pliocene/ } \\
\text { late Miocene }\end{array}$ \\
\hline 5 & $35.5-45.0$ & 69 & • & $*$ & $\begin{array}{l}\text { Pliocene/ } \\
\text { late Miocene }\end{array}$ & • & $\begin{array}{l}\text { Late Pliocene } \\
\text { late Miocene }\end{array}$ & + & $\begin{array}{l}\text { Early Pliocene/ } \\
\text { late Miocene }\end{array}$ \\
\hline 6 & $45.0-54.5$ & 87 & $*$ & + & $\begin{array}{l}\text { Late Miocene/ } \\
\text { late Oligocene }\end{array}$ & $\bullet$ & $\begin{array}{l}\text { Late Miocene/ } \\
\text { late Oligocene }\end{array}$ & - & - \\
\hline 7 & $54.5-64.0$ & 100 & + & + & Late? Oligocene & $\bullet$ & Late Oligocene & - & - \\
\hline 8 & $64.0-73.0$ & $100-$ & $*$ & + & Oligocene & $\bullet$ & Oligocene & - & - \\
\hline 9 & $73.0-82.0$ & $100+$ & $\bullet$ & o & $\begin{array}{l}\text { Early Oligocene } \\
\text { late Eocene }\end{array}$ & $\bullet$ & $\begin{array}{l}\text { Early Oligocene/ } \\
\text { late Eocene }\end{array}$ & - & - \\
\hline 10 & $82.0-91.5$ & 74 & $\bullet$ & * & $\begin{array}{l}\text { Late Eocene/ } \\
\text { Middle Eocene }\end{array}$ & $\bullet$ & Middle Eocene & - & - \\
\hline 11 & $91.5-101.0$ & 93 & $\bullet$ & + & Early Eocene & $\bullet$ & Early Eocene & - & - \\
\hline 12 & $101.0-110.5$ & 76 & $\bullet$ & + & Early Eocene & $\bullet$ & Early Eocene & - & - \\
\hline 13 & $110.5-120.0$ & 95 & $\bullet$ & + & Late Paleocene & $\bullet$ & Late Paleocene & - & - \\
\hline 14 & $120.0-129.5$ & 72 & $\bullet$ & + & $\begin{array}{l}\text { Late/middle } \\
\text { Paleocene }\end{array}$ & - & $\begin{array}{l}\text { Late/early } \\
\text { Paleocene }\end{array}$ & - & - \\
\hline 15 & $129.5-139.0$ & 71 & * & * & $\begin{array}{l}\text { Late } \\
\text { Maestrichtian }\end{array}$ & - & $\begin{array}{l}\text { Late } \\
\text { Maestrichtian }\end{array}$ & - & - \\
\hline 16 & $139.0-148.5$ & 82 & $\bullet$ & + & $\begin{array}{l}\text { Late } \\
\text { Maestrichtian }\end{array}$ & $\bullet$ & $\begin{array}{l}\text { Late } \\
\text { Maestrichtian }\end{array}$ & - & - \\
\hline 17 & $148.5-158.0$ & 98 & $\bullet$ & + & $\begin{array}{l}\text { Middle } \\
\text { Maestrichtian }\end{array}$ & $\bullet$ & Maestrichtian & - & - \\
\hline 18 & $158.0-167.0$ & 89 & $\bullet$ & + & $\begin{array}{l}\text { Early } \\
\text { Maestrichtian }\end{array}$ & $\bullet$ & $\begin{array}{l}\text { Early Maestrichtian/ } \\
\text { late Campanian }\end{array}$ & - & - \\
\hline 19 & $167.0-176.5$ & 96 & - & + & $\begin{array}{l}\text { Early } \\
\text { Maestrichtian }\end{array}$ & - & $\begin{array}{l}\text { E. Maestrichtian/ } \\
\text { 1. Campanian }\end{array}$ & - & - \\
\hline 20 & $176.5-186.0$ & 79 & - & + & $\begin{array}{l}\text { Early } \\
\text { Maestrichtian }\end{array}$ & $\bullet$ & $\begin{array}{l}\text { E. Maestrichtian/ } \\
\text { late Campanian }\end{array}$ & - & - \\
\hline 21 & $186.0-195.5$ & 94 & o & & Late Campanian & $\bullet$ & $\begin{array}{l}\text { E. Maestrichtian/ } \\
\text { late Campanian }\end{array}$ & - & - \\
\hline 22 & $195.5-205.0$ & $<1$ & - & - & - & 0 & $\begin{array}{l}\text { E. Maestrichtian/ } \\
\text { late Campanian }\end{array}$ & - & - \\
\hline 23 & $205.0-214.0$ & 98 & $\bullet$ & $*$ & Late Campanian & $\bullet$ & Late Campanian & - & - \\
\hline 24 & $214.0-223.5$ & 74 & $\bullet$ & + & Early Campanian & - & $\begin{array}{l}\text { Late/early } \\
\text { Campanian } \\
\end{array}$ & - & - \\
\hline 25 & $223.5-233.0$ & 84 & $\bullet$ & + & Early Campanian & $\bullet$ & Early Campanian & - & - \\
\hline 26 & $233.0-242.0$ & 76 & $\bullet$ & + & Early Campanian & $\bullet$ & Early Campanian & - & - \\
\hline 27 & $242.0-251.5$ & 32 & $\bullet$ & + & Early Campanian & $\bullet$ & Early Campanian & - & - \\
\hline 28 & $251.5-261.0$ & 42 & $\bullet$ & + & Early Campanian & $\bullet$ & $\begin{array}{l}\text { Santonian/ } \\
\text { late Turonian }\end{array}$ & - & - \\
\hline 29 & $261.0-270.5$ & $<1$ & $\bullet$ & + & Santonian & $\bullet$ & $\begin{array}{l}\text { Santonian/ } \\
\text { late Turonian }\end{array}$ & - & - \\
\hline 30 & $270.5-280.0$ & $<1$ & $\bullet$ & + & Santonian & - & $\begin{array}{l}\text { Santonian/ } \\
\text { late Turonian }\end{array}$ & - & - \\
\hline 31 & $280.0-289.5$ & $<1$ & $\bullet$ & + & Santonian & - & $\begin{array}{l}\text { Santonian/ } \\
\text { late Turonian }\end{array}$ & + & $\begin{array}{l}\text { Campanian/ } \\
\text { Santonian }\end{array}$ \\
\hline 32 & $289.5-298.5$ & $<1$ & $\bullet$ & + & Santonian & • & $\begin{array}{l}\text { Santonian/ } \\
\text { late Turonian }\end{array}$ & + & $\begin{array}{l}\text { Campanian/ } \\
\text { Santonian } \\
\end{array}$ \\
\hline 33 & $298.5-308.0$ & $<1$ & - & - & - & • & $\begin{array}{l}\text { Santonian/ } \\
\text { late Turonian }\end{array}$ & + & - \\
\hline 34 & $308.0-317.5$ & 2 & - & - & - & - & $\begin{array}{l}\text { Early Turonian/ } \\
\text { Cenomanian }\end{array}$ & + & - \\
\hline
\end{tabular}


TABLE 6 - Continued

\begin{tabular}{|c|c|c|c|c|c|c|c|c|c|}
\hline \multirow{2}{*}{ ن } & \multirow[b]{2}{*}{ Depth (m) } & \multirow{2}{*}{ 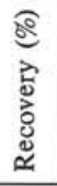 } & \multicolumn{3}{|c|}{ Foraminifera } & \multirow{2}{*}{\multicolumn{2}{|c|}{$\begin{array}{c}\text { Calcareous } \\
\text { Nannoplankton }\end{array}$}} & \multirow{2}{*}{\multicolumn{2}{|c|}{ Radiolaria }} \\
\hline & & & $\frac{\pi}{2}$ & Фี & & & & & \\
\hline 35 & $317.5-326.5$ & 3 & + & + & Coniacian & • & $\begin{array}{l}\text { Early Turonian/ } \\
\text { Cenomanian }\end{array}$ & - & - \\
\hline 36 & $326.5-336.0$ & 4 & - & - & - & o & $\begin{array}{l}\text { Early Turonian/ } \\
\text { Cenomanian }\end{array}$ & - & - \\
\hline 37 & $336.0-345.5$ & 4 & + & - & $\begin{array}{l}\text { Early } \\
\text { Cenomanian }\end{array}$ & * & $\begin{array}{l}\text { Early Turonian/ } \\
\text { Cenomanian }\end{array}$ & * & - \\
\hline 38 & $345.5-354.5$ & 2 & - & - & - & $\bullet$ & $\begin{array}{l}\text { Early Cenomanian/ } \\
\text { late Albian }\end{array}$ & - & - \\
\hline 39 & $354.5-364.0$ & 2 & * & + & $\begin{array}{l}\text { Early } \\
\text { Cenomanian }\end{array}$ & $\bullet$ & $\begin{array}{l}\text { Early Cenomanian/ } \\
\text { late Albian }\end{array}$ & o & - \\
\hline 40 & $364.0-373.5$ & 1 & $*$ & + & $\begin{array}{l}\text { Early } \\
\text { Cenomanian } \\
\end{array}$ & $\bullet$ & $\begin{array}{l}\text { Early Cenomanian/ } \\
\text { late Albian }\end{array}$ & - & - \\
\hline 41 & $373.5-382.5$ & 1 & $*$ & + & $\begin{array}{l}\text { Early } \\
\text { Cenomanian }\end{array}$ & • & Late Albian & + & - \\
\hline 42 & $382.5-391.5$ & 6 & $*$ & + & Late Albian & $\bullet$ & Late Albian & $*$ & $=$ \\
\hline 43 & $391.5-400.5$ & 40 & 0 & + & (caved) & $\bullet$ & Late Albian & - & - \\
\hline 44 & $410.0-419.0$ & 2 & $*$ & + & Late Albian & $\bullet$ & Late Albian & $*$ & - \\
\hline 45 & $419.0-428.5$ & 1 & * & + & Late Albian & $\bullet$ & Late Albian & * & - \\
\hline 46 & $428.5-438.0$ & 2 & * & + & Late Albian & o & Late Albian & o & - \\
\hline 47 & $438.0-447.5$ & 7 & + & + & Albian & $\bullet$ & Late Albian & $*$ & - \\
\hline 48 & $447.5-456.5$ & 1 & - & - & - & $\bullet$ & Late Albian & - & - \\
\hline 49 & $456.5-466.0$ & $<1$ & + & + & Albian & o & Late Albian & 0 & - \\
\hline 50 & $466.0-475.5$ & $<1$ & + & + & Albian & o & Late Albian & o & - \\
\hline 51 & $475.5-484.5$ & 1 & + & + & Albian & $\bullet$ & Late Albian & 0 & - \\
\hline 52 & $484.5-494.0$ & 1 & + & + & Albian & $\bullet$ & (Mesozoic) & $\bullet$ & - \\
\hline 53 & $494.0-503.5$ & 1 & - & - & (caved) & $*$ & (Mesozoic) & - & - \\
\hline 54 & $503.5-513.0$ & 2 & + & + & Albian/Aptian & $\bullet$ & Early Albian & - & - \\
\hline 55 & $513.0-522.0$ & 1 & - & - & - & o & $\begin{array}{l}\text { Early Albian/ } \\
\text { late Aptian }\end{array}$ & + & - \\
\hline 56 & $522.0-531.5$ & 3 & - & - & - & $*$ & $\begin{array}{l}\text { Early Albian/ } \\
\text { late Aptian }\end{array}$ & + & - \\
\hline 57 & $531.5-541.0$ & 3 & * & + & Aptian & o & $\begin{array}{l}\text { Early Albian/ } \\
\text { late Aptian }\end{array}$ & + & - \\
\hline 58 & $541.0-550.5$ & 4 & + & - & Aptian & • & $\begin{array}{l}\text { Early Aptian/ } \\
\text { Barremian }\end{array}$ & + & - \\
\hline 59 & $550.5-560.0$ & 5 & * & * & Aptian & $\bullet$ & $\begin{array}{l}\text { Early Aptian/ } \\
\text { Barremian }\end{array}$ & o & - \\
\hline 60 & $560.0-569.5$ & 7 & - & + & - & $\bullet$ & $\begin{array}{l}\text { Early Aptian/ } \\
\text { Barremian }\end{array}$ & o & - \\
\hline 61 & $569.5-579.0$ & 4 & - & - & - & • & $\begin{array}{l}\text { Early Aptian/ } \\
\text { Barremian }\end{array}$ & o & - \\
\hline 62 & $579.0-588.5$ & 1 & - & - & - & • & $\begin{array}{l}\text { Early Aptian/ } \\
\text { Barremian }\end{array}$ & + & - \\
\hline 63 & $588.5-598.0$ & 8 & - & + & - & • & $\begin{array}{l}\text { Early Aptian/ } \\
\text { Barremian }\end{array}$ & o & - \\
\hline 64 & $598.0-607.0$ & 5 & + & $*$ & $\begin{array}{l}\text { Aptian/ } \\
\text { Barremian }\end{array}$ & $\bullet$ & $\begin{array}{l}\text { Early Aptian/ } \\
\text { Barremian }\end{array}$ & o & - \\
\hline 65 & $607.0-616.5$ & 11 & - & - & - & o & $\begin{array}{l}\text { Early Aptian/ } \\
\text { Barremian }\end{array}$ & o & - \\
\hline 66 & $616.5-626.0$ & 7 & - & + & $\begin{array}{l}\text { Aptian/ } \\
\text { Barremian }\end{array}$ & o & Hauterivian & o & - \\
\hline 67 & $626.0-635.5$ & 1 & + & + & $\begin{array}{l}\text { Aptian/ } \\
\text { Barremian }\end{array}$ & $\bullet$ & $\begin{array}{l}\text { Hauterivian/ } \\
\text { Valanginian }\end{array}$ & + & - \\
\hline 68 & $635.5-640.5$ & 1 & - & - & - & • & $\begin{array}{l}\text { Hauterivian/ } \\
\text { Valanginian }\end{array}$ & + & - \\
\hline
\end{tabular}

Note: $\bullet$ abundant; o common, * frequent; + rare; - absent. 


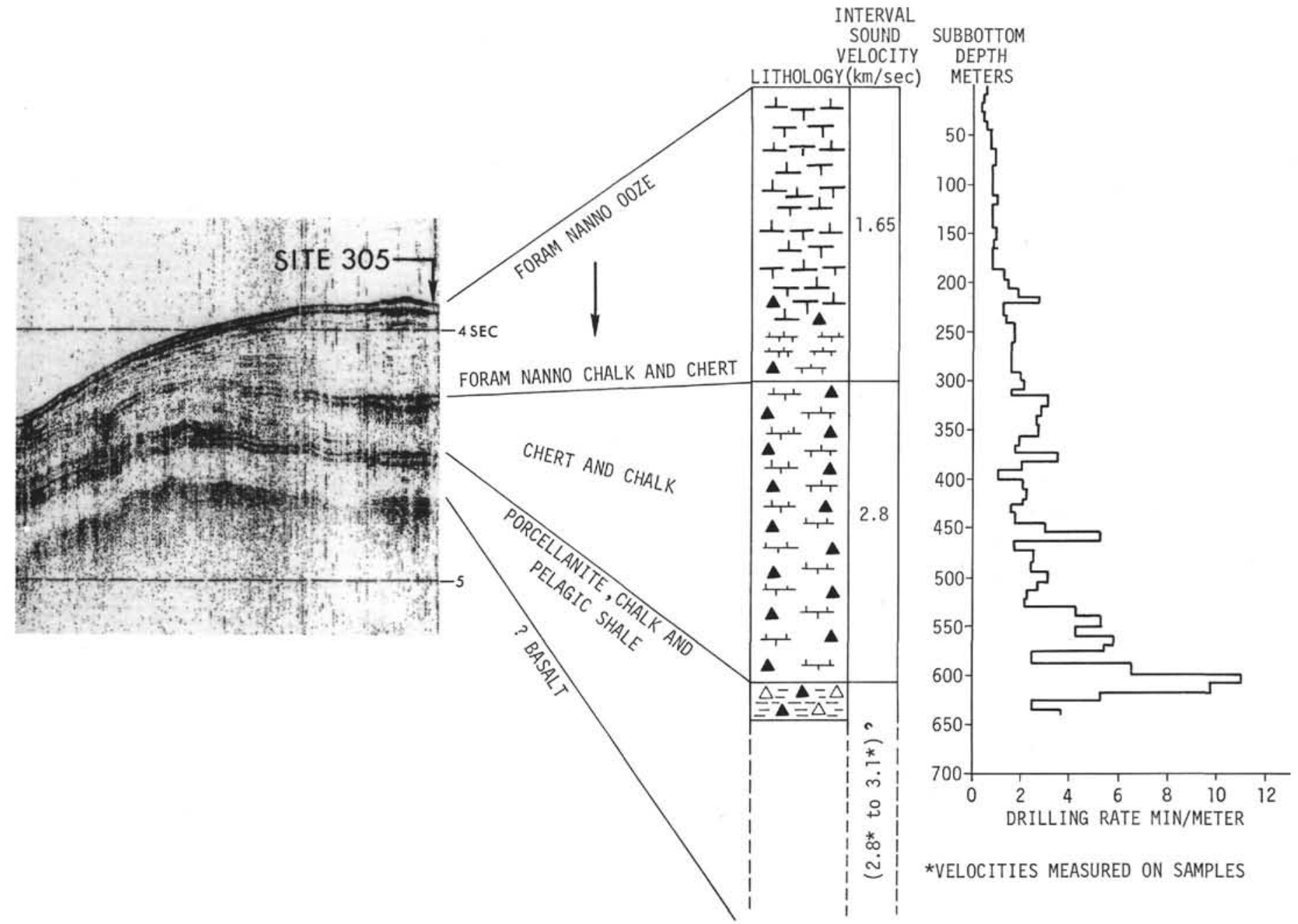

Figure 8. Correlation of seismic reflection profile with drilling results at Site 305.

Foraminifera

The Neogene sequence (Cores 1-6) contains abundant foraminiferal populations which show evidence throughout of intense carbonate dissolution. The assemblages which are dominated by planktonic species are characteristic of temperate water and include rare subtropical elements.

Cores 1 and 2 are attributed to the Pleistocene (N23N22) based on the presence of Globorotalia truncatulinoides. The interval from Core 2 to Core 5 , Section 4 are attributed to the Pliocene; the lowest occurrence of Globorotalia inflata marking the N21/N20 boundary (late/early Pliocene) between Sections 2 and 3 of Core 4 .

Assemblages from the interval between Core 5, Section 5 to Core 6 , Section 3 belong to the late Miocene Zones N16 to N17, whereas those of the lower part of Core 6 , which contain mixed faunas, are attributed to the middle Miocene (N6 to N9).

Oligocene planktonic foraminifera are present reworked into younger middle Miocene assemblages in Core 6 , Section 5 but the highest occurrence of Oligocene faunas in situ is in Core 6, Section 6. The fauna from the latter section, as well as from Core 7, are assigned to Zone P22, whereas those of Core 8, Sections
1 and 2 are attributed to Zone P19 and those from the remainder of Core 8 to Zone P18. Early Oligocene assemblages are present as low as Core 9, Section 2.

The limit between the early Oligocene and the late Eocene is drawn between Sections 2 and 3 of Core 9 based on the first occurrence of Hantkenina sp. Most of the microfaunas of Cores 9 and 10 are strongly affected by solution. In addition, a few assemblages are mixed by reworking or contamination. Therefore, no zonal subdivision of the late and middle Eocene could be established. The top of the middle Eocene is recognized in Section 5 of Core 10, whereas the core-catcher sample of the same core belongs to the older part of the middle Eocene.

Core 11 contains rich and well-preserved microfaunas which are almost exclusively composed of planktonic foraminifera. The assemblages are attributed to the upper part of the early Eocene (Globorotalia aragonensis Zone and Globorotalia pentacamerata Zone). The base of the Globorotalia pentacamerata Zone is drawn at the first occurrence of Globigerina frontosa subbotina in Sample 11-4, 20-22 cm.

All samples examined from Core 12 contain Globorotalia formosa formosa and other species characteristic 
for the homonymous zone of the early Eocene. All microfaunas are rich in well-preserved planktonic foraminifera which display no or only weak traces of dissolution. The abrupt change in the composition of the planktonic foraminiferal assemblages between the top of Core 13 and the base of Core 12 indicates the possible absence of the Globorotalia subotinae Zone (oldest zone of the early Eocene).

The planktonic foraminiferal assemblages from Sections 6 to 1 of Cores 13 are typical for the late Paleocene Globorotalia velascoensis Zone. The two samples from Sections 2 and 3 show strong indications of carbonate dissolution which affects mainly the large keeled Globorotalia spp.

Globorotalia pseudomenardii, the marker for the lower zone of the late Paleocene, is present in Sections 3 to 1 of Core 14 and in the core-catcher sample of Core 13. The solution of planktonic foraminiferal tests is weak except in Sample 14-3, 42-44 cm.

The core-catcher sample and those from Sections 4 and 5 of Core 14 are attributed to the middle Paleocene Globorotalia pusilla pusilla Zone. Lumps of white chalk in the core-catcher sample have been washed separately. They contain a rich and well-preserved microfauna of the early Paleocene Globorotalia trinidadensis Zone mixed with specimens from the middle Paleocene Globorotalia uncinata and Globorotalia angulata zones.

The microfaunas of Core 15 indicate strong dissolution. Well-preserved planktonic foraminifera are very rare. The benthonic foraminifera (Neoflabellina spp., Bolivinita spp., and others) are of Maestrichtian age. Cores 16 through 20 have rich and well-preserved planktonic foraminifera which are attributed to the Maestrichtian. The presence of Globotruncana mayaroensis in Core 16 indicates the youngest zone of the Maestrichtian, whereas Core 17 is placed into the middle Maestrichtian (zone with Globotruncana contus and Globotruncana rugosa). Cores 18 through 20 are of early Maestrichtian age (zone with Globotruncana stuartiformis and Globotruncana elevata).

Globorotruncana calcarata, the marker of the topmost zone of the Campanian, is well represented in Cores 21 and 23. No washed residues could be obtained from Core 22. Cores 24 through 29 are of early Campanian age (zone with Globotruncana stuartiformis and Globorotruncana fornicata).

Below Core 29, recovery is very poor. No washed residues are available from Cores 33,34 , and 36 , whereas other samples are contaminated by cavings (e.g., core-catcher sample of Core 35 ).

The small core-catcher samples of Cores 30 and 31 are of late Santonian age (Globotruncana carinata Zone). Core 32 may be of early Santonian age.

Recovery from Cores 37 to 68 is very poor; the microfaunas are often of somewhat dubious origin ("cuttings" and "cavings"), others are very poor and badly preserved. In a few cores, only chert chips were recovered and no washed residues could be obtained (see distribution chart in chapter on Early Cretaceous foraminifera).

Slightly bituminous black shales from Section 1 of Core 37 have furnished a few planktonic foraminifera which are placed into the early Cenomanian based on the presence of Rotalipora brotzeni. Cores 37 to 41 are given an early Cenomanian age based on the cooccurrence of Rotalipora brotzeni, $R$. greenhornensis, and $R$. gandolfii.

The part of the section represented by Cores 42 to 46 is of late Albian (to basal Cenomanian) age ("Interval with Rotalipora apenninica"). The presence, composition, and preservation of the microfaunas are very irregular.

The few washed residues of Cores 47 and 49 to 52 contain representatives of the genus Ticinella ( $T$. primula, Ticinella sp. cf. T. raynaudi) and Hedbergella sp. sp. which indicate a middle to early Albian age. The presence of Ticinella primula in Core 54 is uncertain because of poor preservation.

No reliable microfaunas were obtained from Cores 53,55 , and 56 .

The foraminiferal faunas from Cores 57 to 59 are characterized by the presence of Globigerinelloides ferreolensis, G. barri, and Hedbergella aptica and are therefore attributed to the Aptian (probably middle to upper part).

The small samples which could be obtained from Cores 60 to 63 are dominated by Radiolaria.

Dorothia zedlerae appears first in Core 64. It marks the top of the "Interval between first occurrence of Dorothia zedlerae and the first occurrence of Dorothia hauteriviana" (Cores 64 to 67) to which a Barremian (to early Aptian?) age is assigned. Very few specimens of planktonic foraminifera are found in Cores 64 and 67. The presence of very rare Hedbergella aptica and Globigerinelloides gottisi in Core 64 may indicate that at least this core could be still of Aptian age.

No washed residues could be obtained from Core 68 .

\section{Coccoliths}

Coccoliths are generally abundant throughout the 641-meter continuously cored section (Cores 1 to 68). Preservation is moderate to poor as overgrowth and fragmentation have affected most assemblages. Most of the Miocene is missing in the Cenozoic section of Cores 1 to $14(0-130 \mathrm{~m})$. The Mesozoic appears to be complete from Maestrichtian to Valanginian or Hauterivian in Cores 15 to 68 (130-641 m), however, recovery of only trace amounts of sediment below Campanian Core 28 reduces the potential value of Site 305 as a reference section.

The Cretaceous-Tertiary boundary is indicated between Cores 14 and 15 at 130 meters. Preservation immediately above and below this level is especially poor. The only definite early Paleocene was recovered as a trace of white clay in the Core 14 core-catcher sample. Micula mura occurs as part of a late Maestrichtian assemblage at the top of Core 15.

Among the three oldest cores at Site 305, Core 67 $(626-636 \mathrm{~m})$ contains the best assemblage. The presence of Cruciellipsis cuvillieri in Cores 66 to 68 establishes the Neocomian age of these cores. Species present in Core 67 include: Cretarhabdus crenulatus, Cruciellipsis chiasta, C. cuvillieri, Cyclagelosphaera margerelii, Diado- 
rhombus rectus, Diazomatolithus lehmannii, Lithraphidites carniolensis, Parhabdolithus embergeri, Vagalapilla stradneri, Watznaueria barnesae, $W$. bayackii, and $W$. ovata.

\section{Radiolaria}

Well-preserved Radiolaria are present in all of the five Neogene cores recovered. They are common in Cores 1 to 4 and rare in Core 5 .

The diagnostic fossils used by Hays (1970) in his zonation of the North Pacific are either missing or only rarely present and thus his zonation can only be tentatively applied here. The Artostrobium tumidulum Zone is present in Core 1 through Section 2 and the remainder of the core may possibly be attributed to the Axoprunum angelinum Zone, both Pleistocene. Core 2 is Pliocene, possibly Lamprocyrtis heteroporos Zone and Core 3 early Pliocene, above the range of Stichocorys peregrina. Core 4 and Core 5 are considered to belong to the Stichocorys peregrina Zone late Miocene or early Pliocene.

Preservation of Cretaceous Radiolaria was consistently better in the calcareous sediment samples examined than in the cherts. This is in contrast to Sites 303 and 304 where the Cretaceous Radiolaria were consistently better preserved in the cherts. In the calcareous samples Cretaceous Radiolaria are few to common and poorly preserved in Cores 44 to 47 . They are few to abundant and moderately well-preserved in Cores 49 to 52, 58-61, and 63-66. Chert samples from Cores 17, 19, 21, 22, 33, 35 , and 38 contained no Radiolaria. Cores $31,32,34,41$, $42,44,53-57$ contained very rare to few, very poor to poor Radiolaria; Cores 39 and 49 contained common, very poor Radiolaria.

Radiolaria in Cores 31 and 32, at a depth of 280-298.5 meters are considered to be Santonian or Campanian in age. Radiolaria in Core $46(428.5-438 \mathrm{~m})$ belong to the Dictyomitra somphedia Zone; and those in Cores 50 to $52(466-494 \mathrm{~m})$, Cores 58-59 (541-560 m), Cores 60 and $61(560-579 \mathrm{~m})$, and Cores 63 and $64(588-607 \mathrm{~m})$ to the Acaeniotyle umbilicata Zone. Radiolaria in Cores 65 and $66(607-626 \mathrm{~m})$ belong to the Eucyrtis tenuis Zone. A summary of the biostratigraphy of Site 305 is shown in Table 6.

\section{SEDIMENTATION RATES}

Continuous coring through a 641-meter section at Site 305 allows calculation of sedimentation rates of about 8 $\mathrm{m} / \mathrm{m} . \mathrm{y}$. for Pliocene to Pleistocene, $2 \mathrm{~m} / \mathrm{m}$.y. for early middle Eocene to late Oligocene, about $4 \mathrm{~m} / \mathrm{m}$.y. for Maestrichtian to Paleocene, and $7 \mathrm{~m} / \mathrm{m}$.y. for Hauterivian to Aptian (Figure 9). These moderate sedimentation rates are similar to those at nearby Site 47 where sedimentation rates are 8 to $14 \mathrm{~m} / \mathrm{m}$.y. for Pliocene to Pleistocene, 2 to $4 \mathrm{~m} / \mathrm{m}$.y. for Paleocene to Eocene, and 7 to $9 \mathrm{~m} / \mathrm{m} . \mathrm{y}$. for the Maestrichtian.

An erosion surface indicated from samples within Core 6 removed portions of early Miocene, and late Oligocene. A similar break in the stratigraphic section at Site 47 is more inclusive, as the middle Eocene to upper Miocene is missing. An unconformity between Cores 10 and 11 removed most of the mid Eocene. The basal early
Eocene is also missing between Cores 12 and 13 .

The formation of numerous chert beds and hard chalks through compaction and diagenesis in the Cretaceous section suggests that the calculated accumulation rates of 6 to $9 \mathrm{~m} / \mathrm{m}$.y. are minimum figures. A lack of definitive late Cenomanian to Turonian assemblages might also suggest some variation of Cretaceous rates.

\section{SUMMARY AND CONCLUSIONS}

The biostratigraphic objectives at Shatsky Rise were not met at Site 305 due in large part to the abundance of chert in the Cretaceous section. A sufficient amount of the softer fossiliferous chalks interbedded with the cherts was recovered for shipboard use in determining the age of the section drilled, but there is little pre-

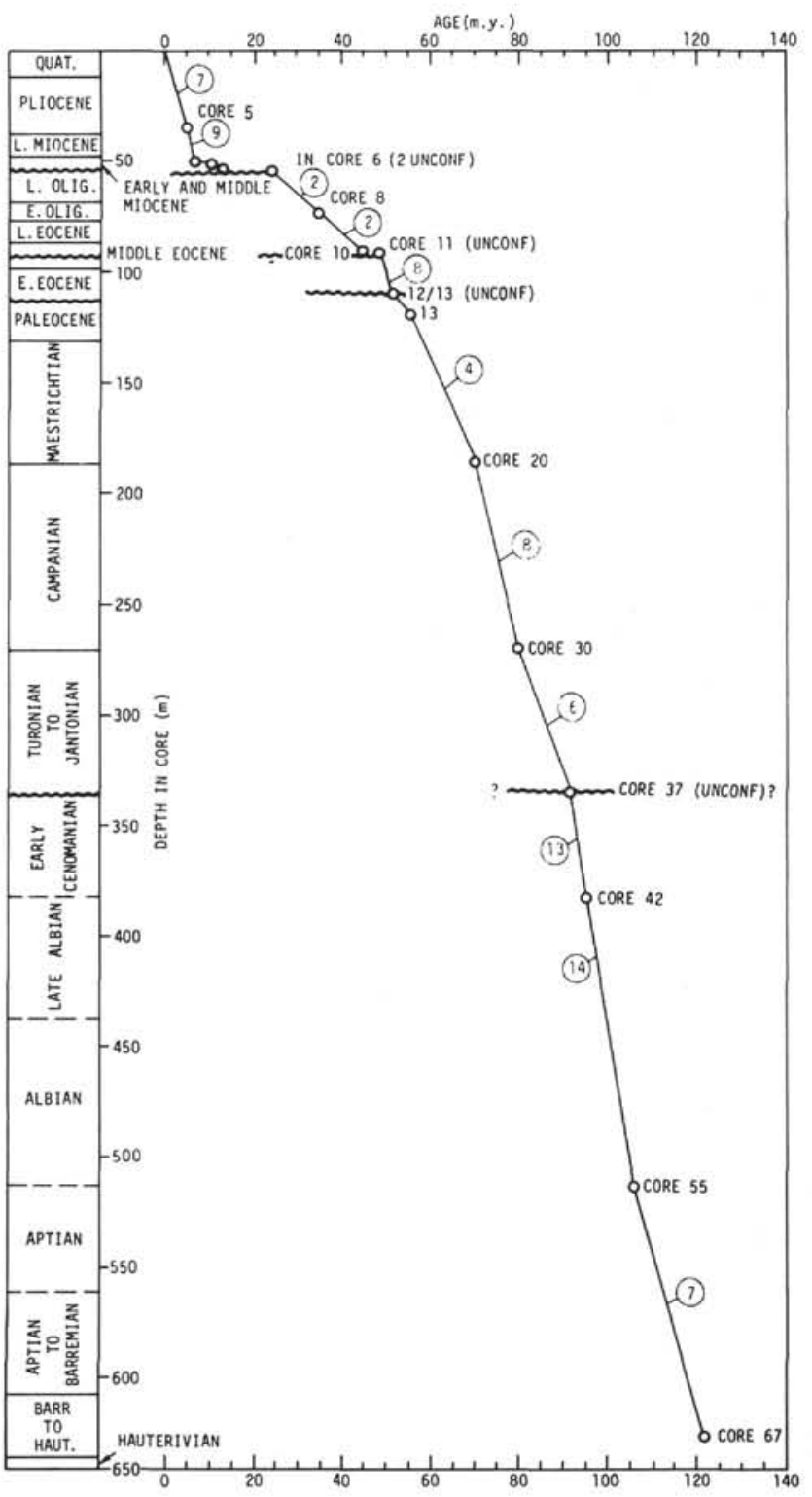

Figure 9. Accumulation rate curve calculated for Site 305. Circled numbers give accumulation rate in $\mathrm{m} / \mathrm{m} . \mathrm{y}$. for each segment. 
Campanian core material available for distribution to the scientific community.

The unsatisfactory state of perservation of the fossils also decreases the value of Shatsky Rise as a Paleogene and late Mesozoic microfossil reference section. The foraminifera generally were the most useful for correlation, but there was not enough noncherty rock recovered below the Albian for good foraminifer control in the lowest sediments. Coccoliths were abundant wherever any carbonate was obtained in the cores, but their value was diminished by their poor to moderate preservation. Radiolaria were absent in the Paleogene and were present only in a spotty distribution in the Cretaceous.

The sedimentation rates suggest that this southern part of Shatsky Rise was under the equator about 90 m.y. ago. Mainly that date is selected because it is the middle of the steepest slope of the sediment-accumulation curve.

We were able, as planned, to core an apparently continuous early Paleogene-latest Cretaceous section below the Miocene unconformity that had been identified on Leg 6. Unfortunately, the era boundary fell between cores.
Neither the base of the sediment section nor basement were reached at this site and so no conclusions can be drawn about pre-Valanginian events. A summary of site data is given in Figure 10.

\section{REFERENCES}

Chase, T. E., Menard, H. W., and Mammerickx, J., 1971. Topography of the North Pacific: Institute of Marine Resources, University of California, San Diego.

Clague, D. A. and Jarrard, R. D., 1973. Tertiary Pacific plate motion deduced from the Hawaiian-Emperor Chain: Geol. Soc. Am. Bull., v. 84, p. 1135-1154.

Hays, J. D., 1970. Stratigraphy and evolutionary trends of Radiolaria in North Pacific sediments: Geol. Soc. Am. Mem., v. 126, p. 185-218.

Jones, J.B. and Segnit, E.R., 1971. The nature of opal. I. nomenclature and constituent phases: J. Geol. Soc. Australia, v. 18, p. 57-68.

Lancelot, Y., Carpenter, G., and Ewing, J. I., in preparation. Sedimentary and tectonic evolution of the Pacific plate since the Early Cretaceous.

Winterer, E. L., 1973. Sedimentary facies and plate tectonics of the Equatorial Pacific: Am. Assoc. Petrol. Geol. Bull., v. 57 , p. $265-282$. 


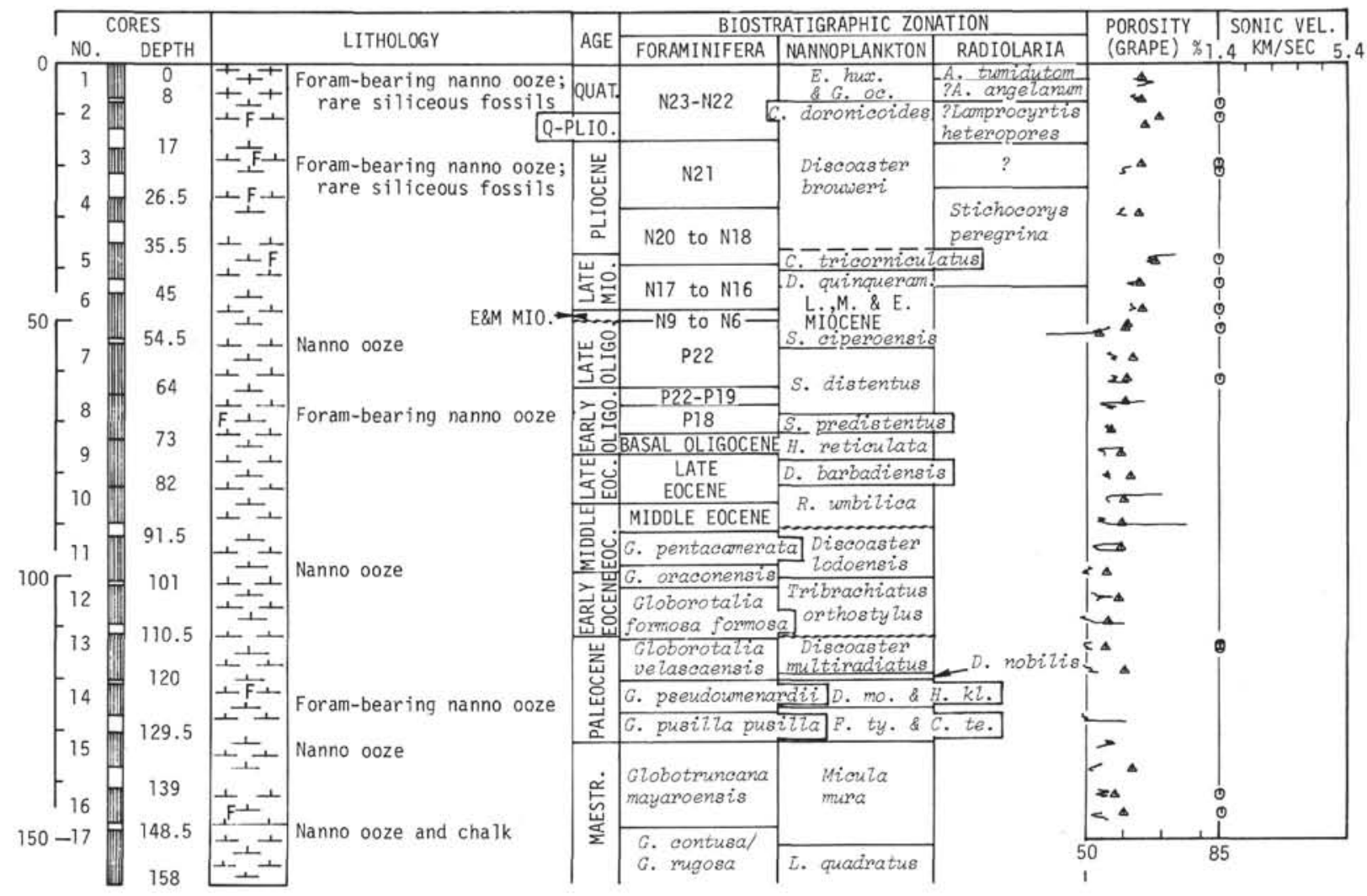

Figure 10. Summary of coring, lithology, biostratigraphy, and physical properties at Site 305.

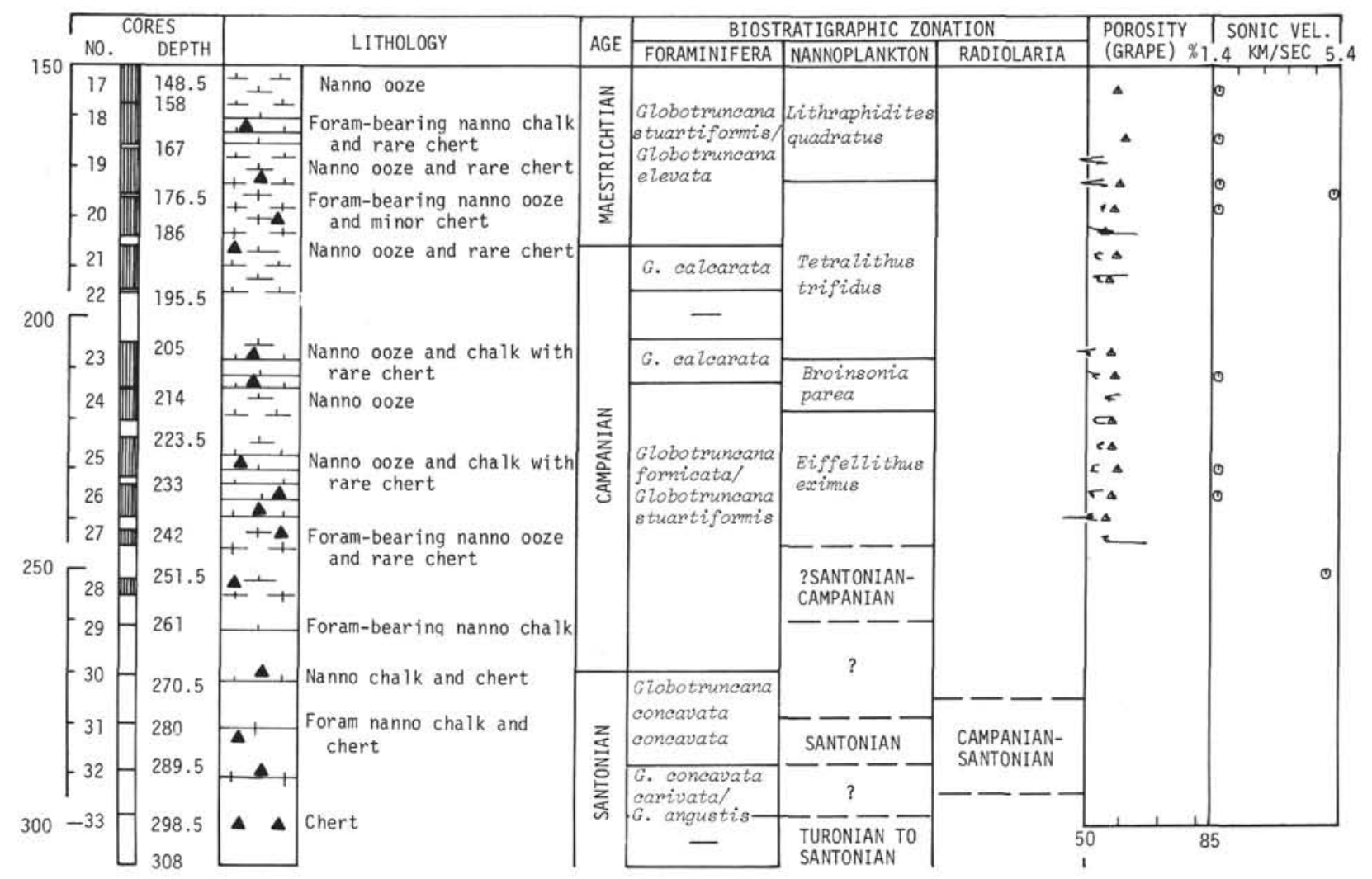

Figure 10. (Continued). 


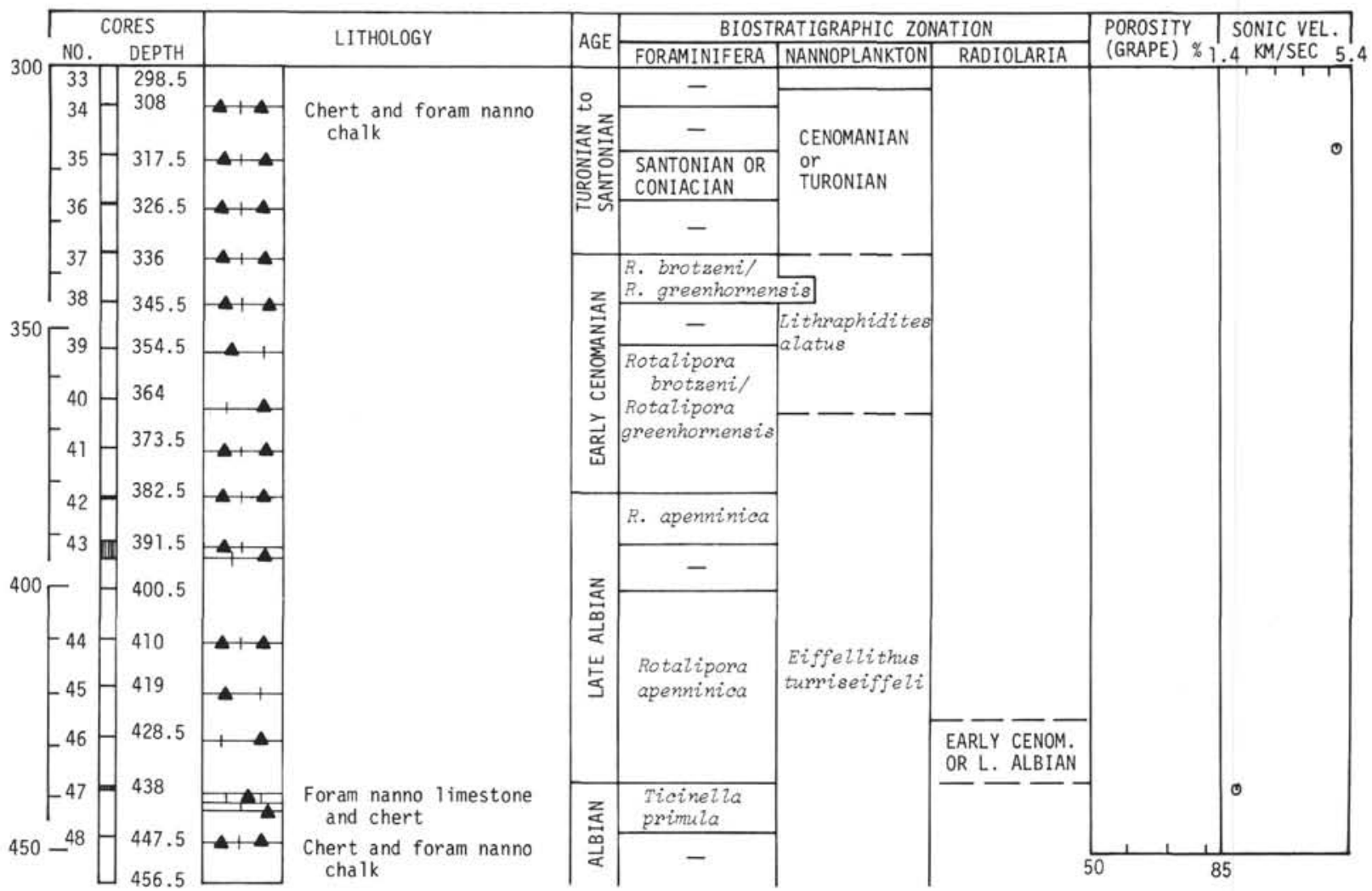

Figure 10. (Continued).

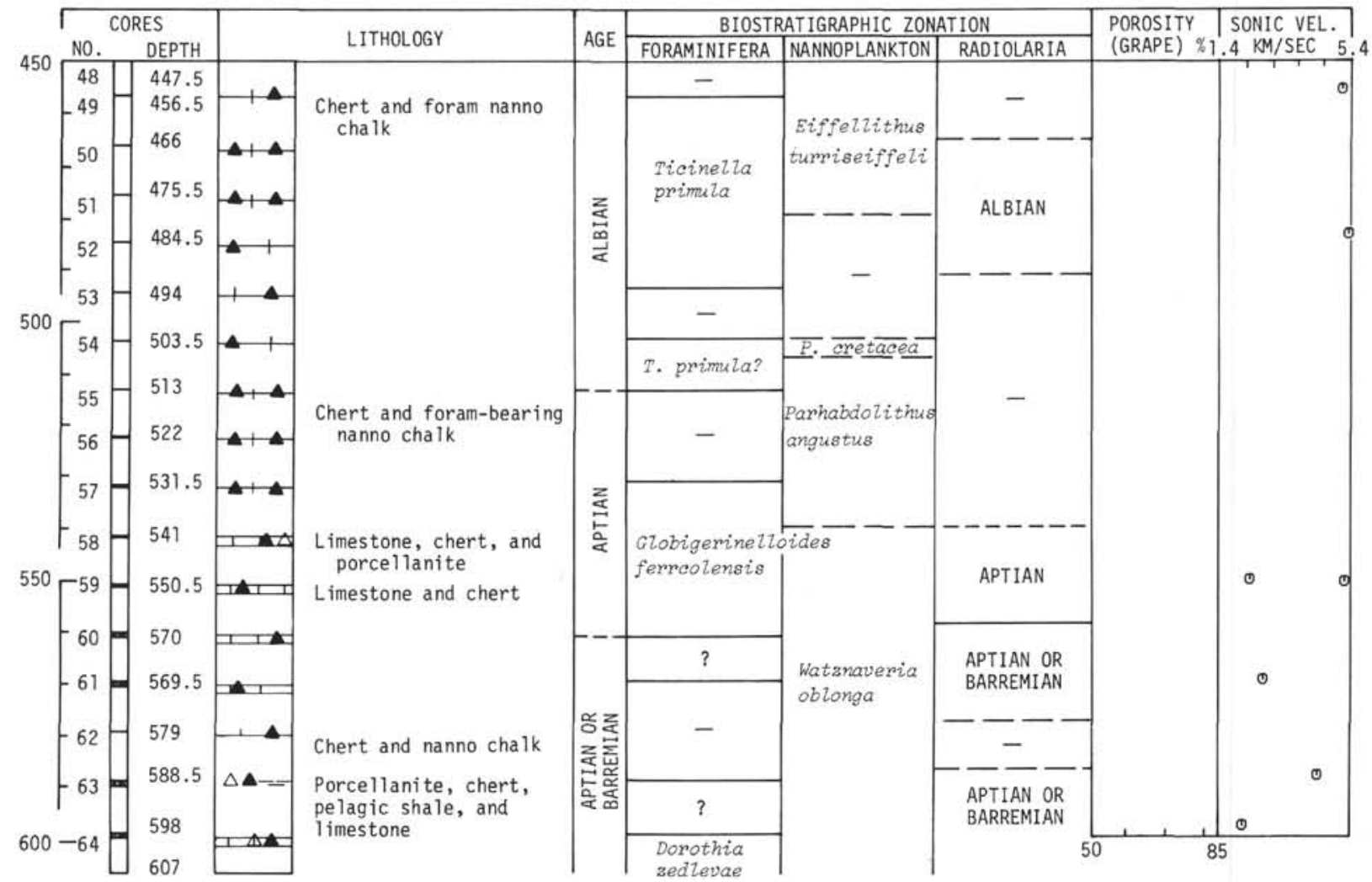

Figure 10. (Continued). 


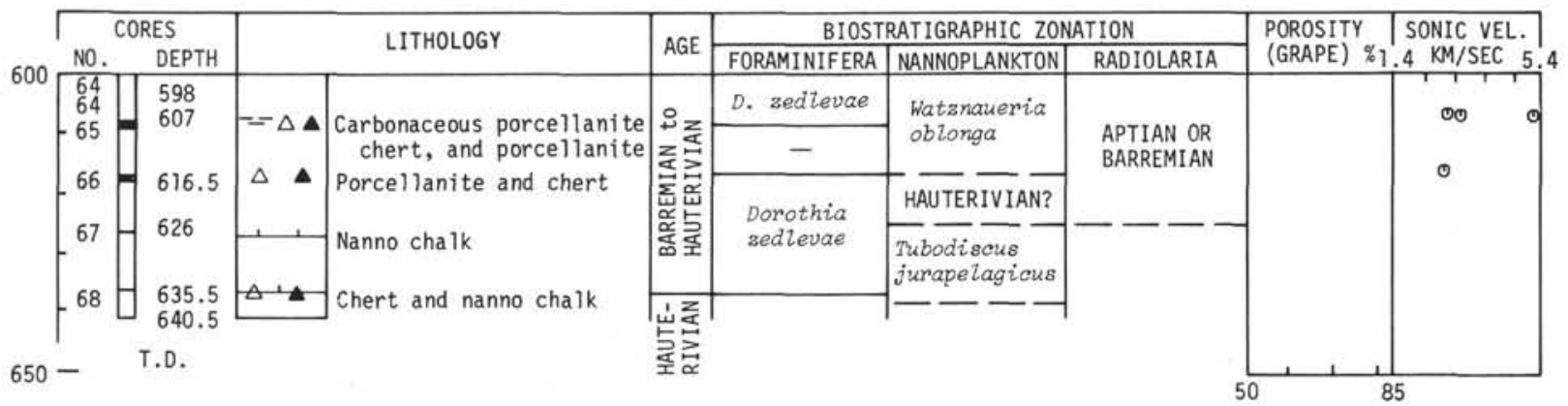

Figure 10. (Continued). 


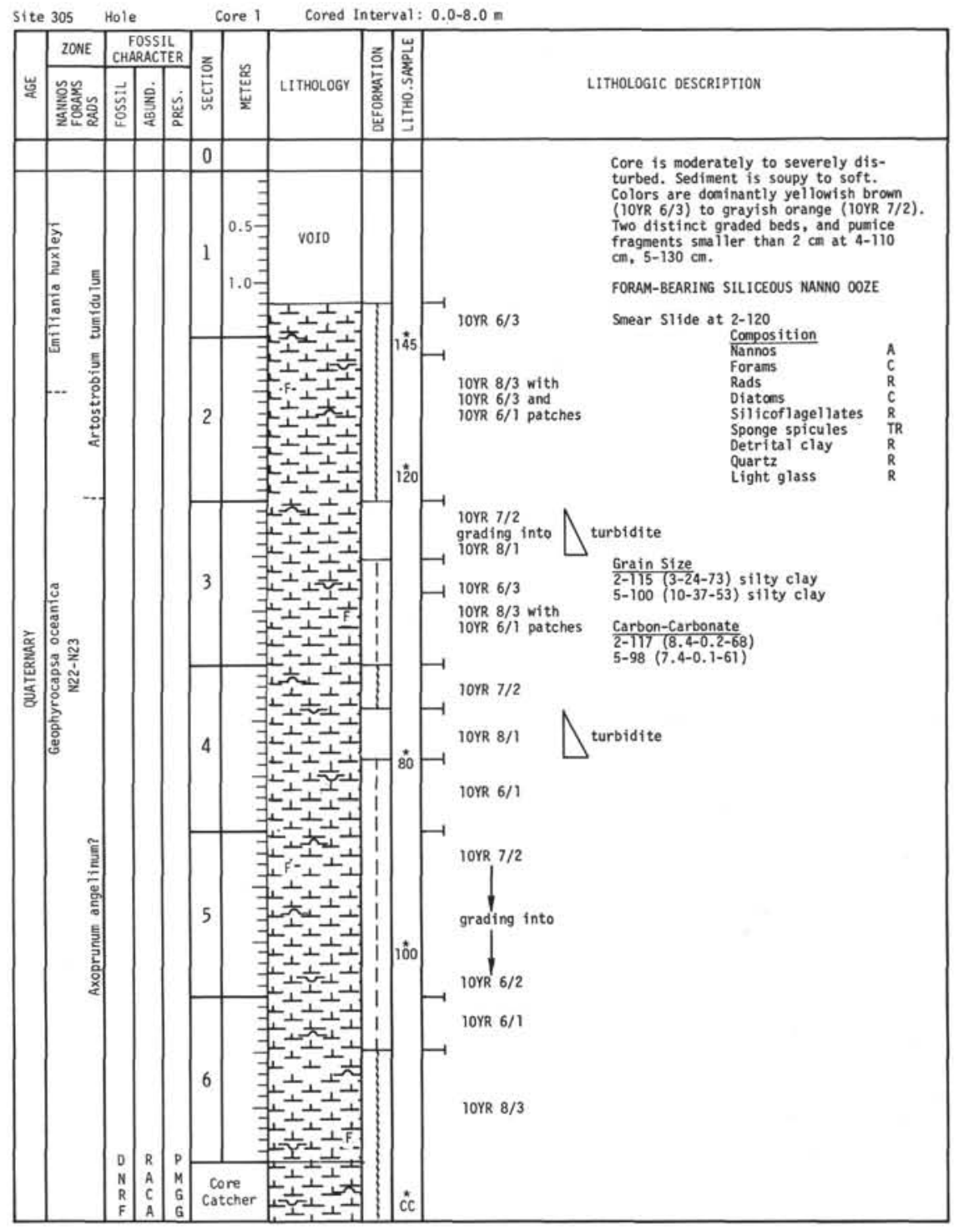

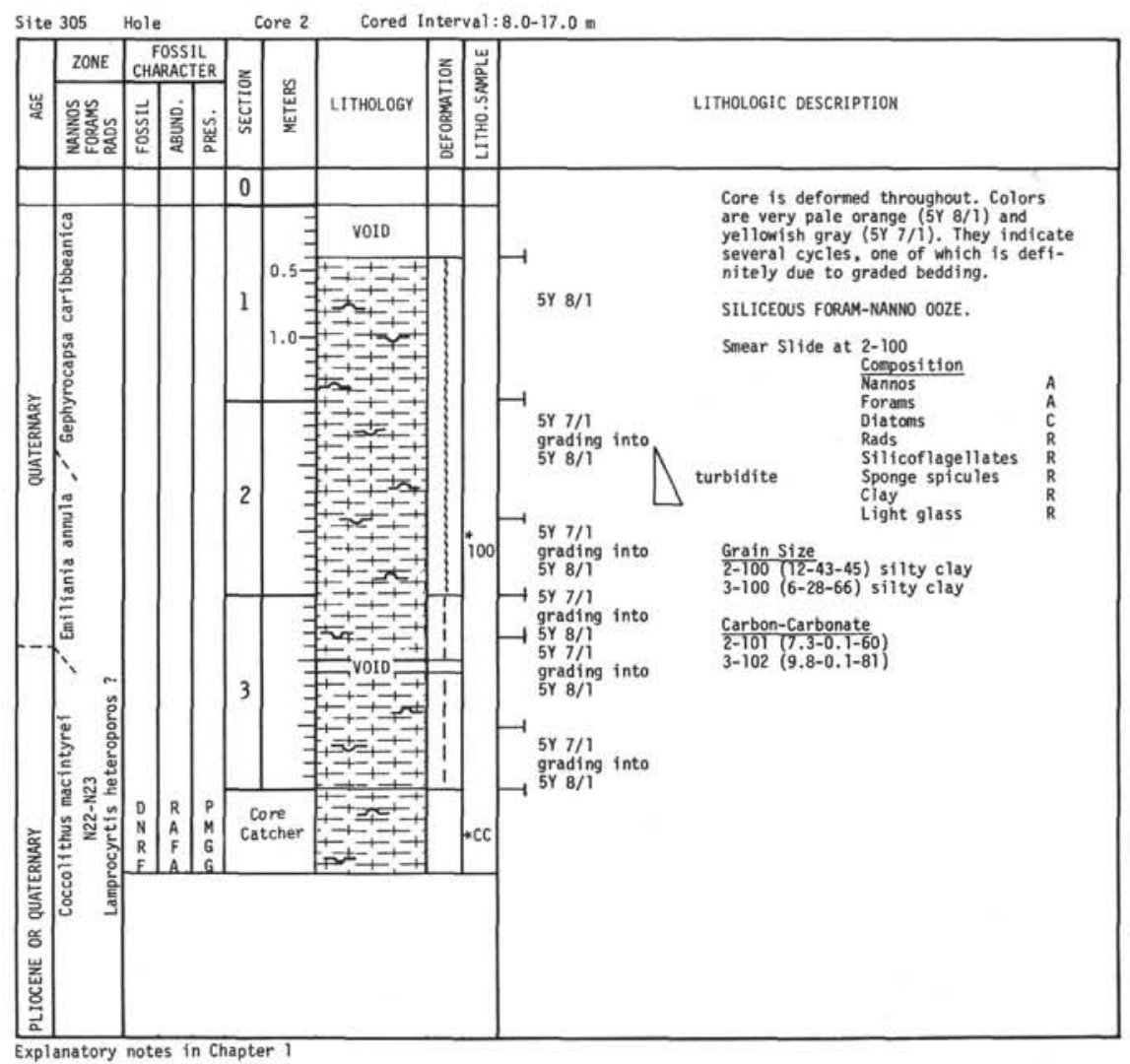


Site 305 Hole Core 3 Cored Interval: $17.0-26.5 \mathrm{~m}$

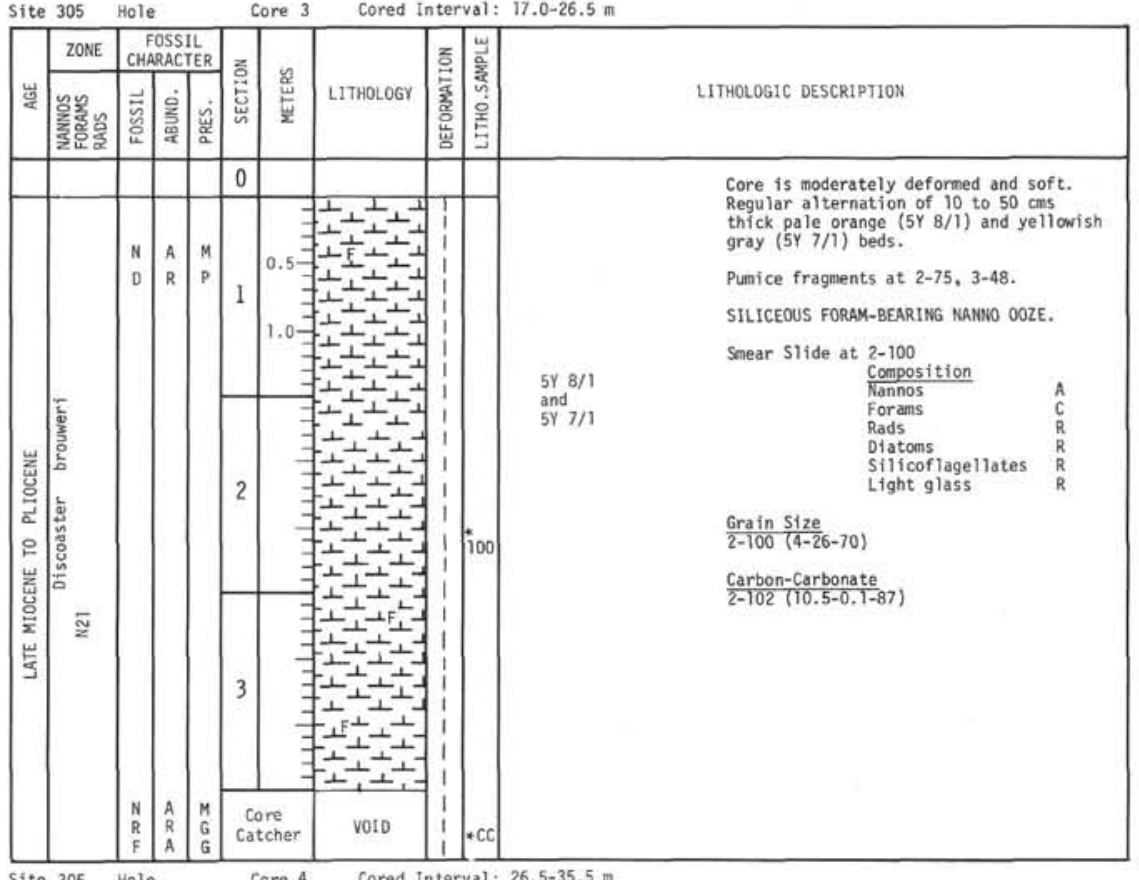

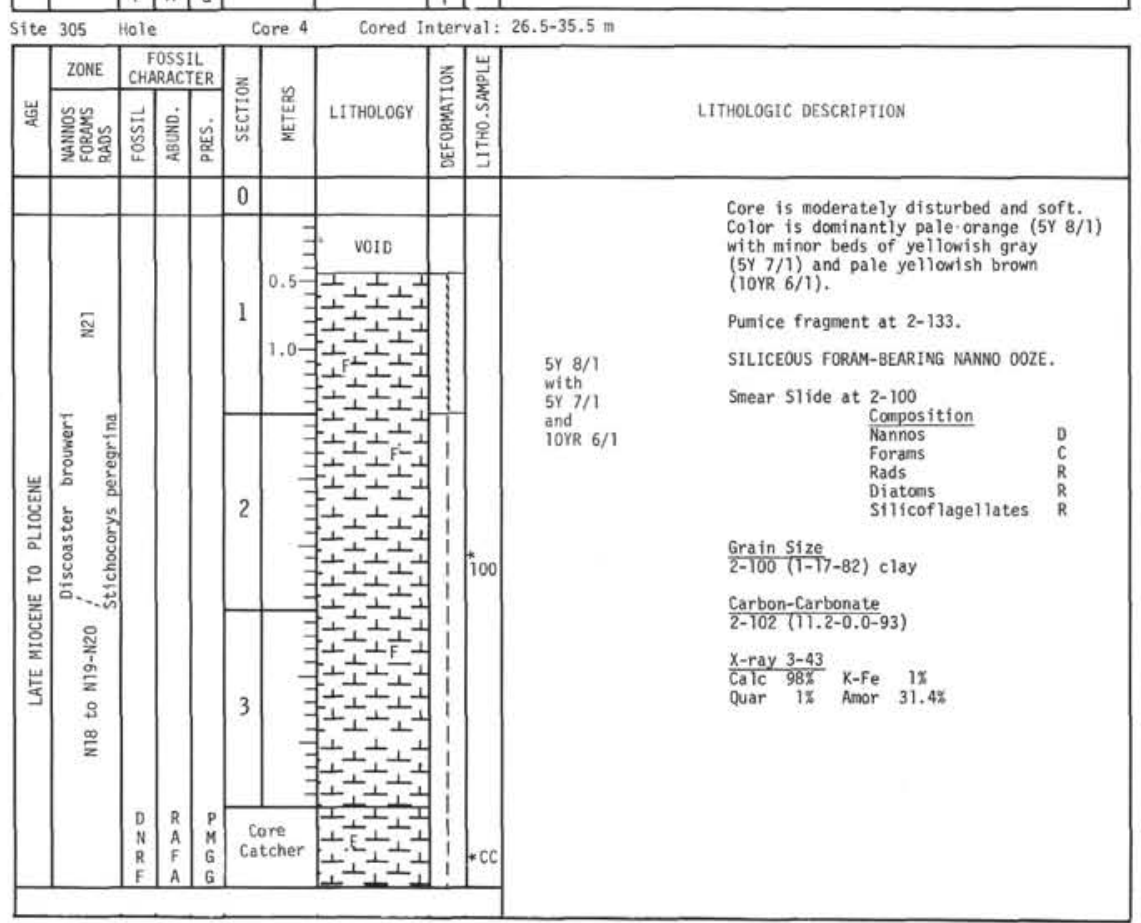

Site 305 Hole Core 5 Cored Interval: $35.5-45.0 \mathrm{~m}$

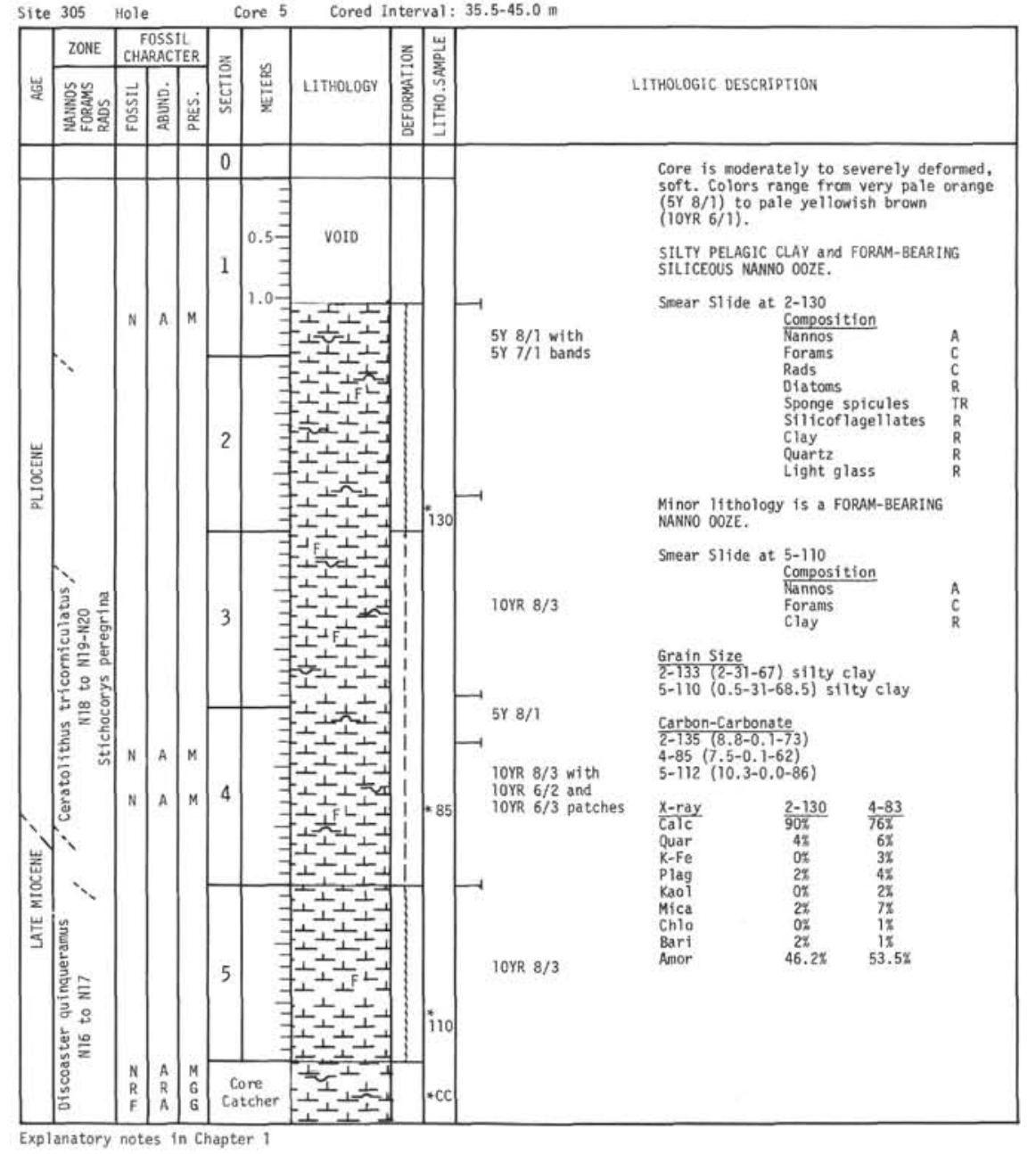



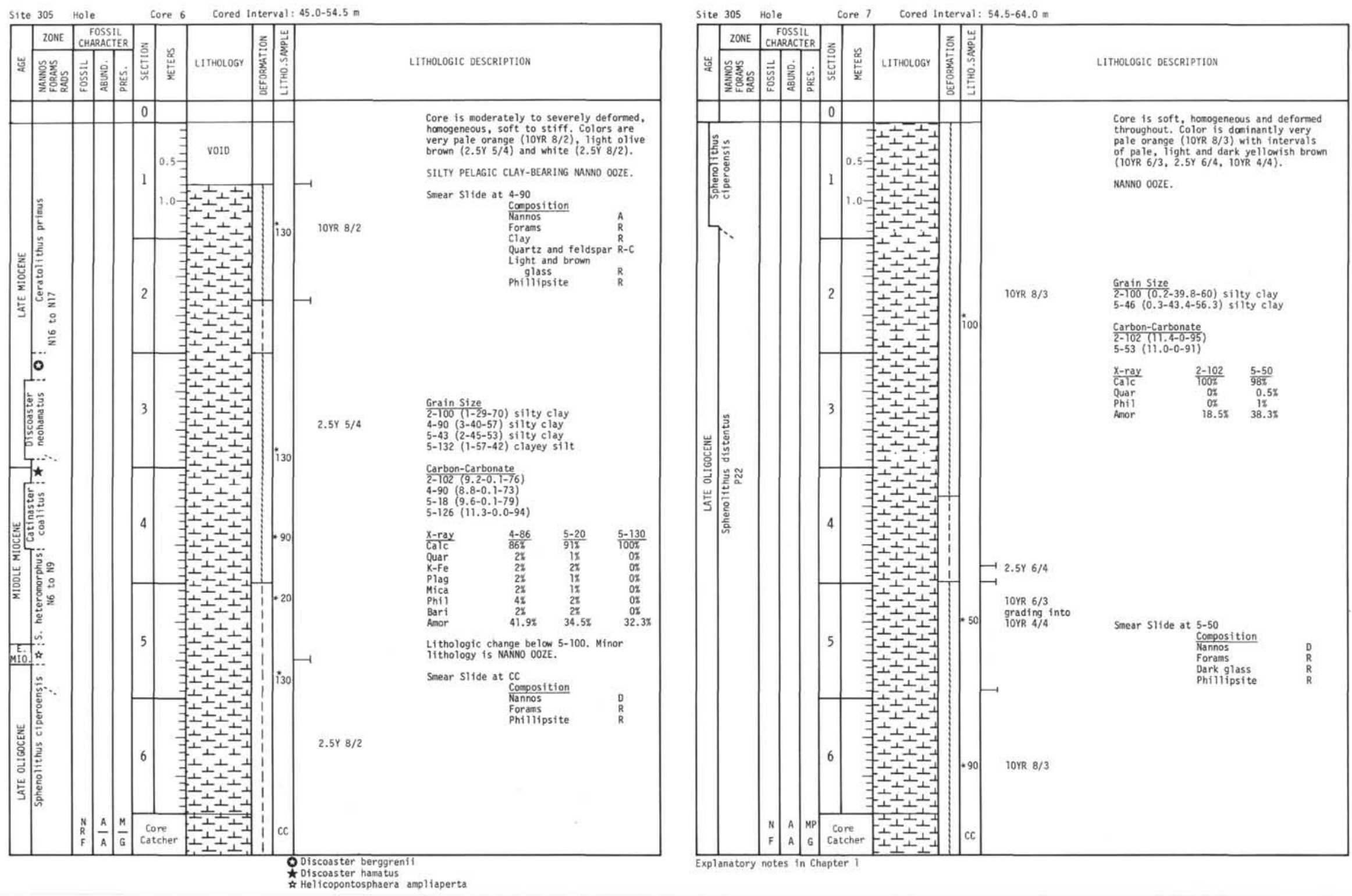


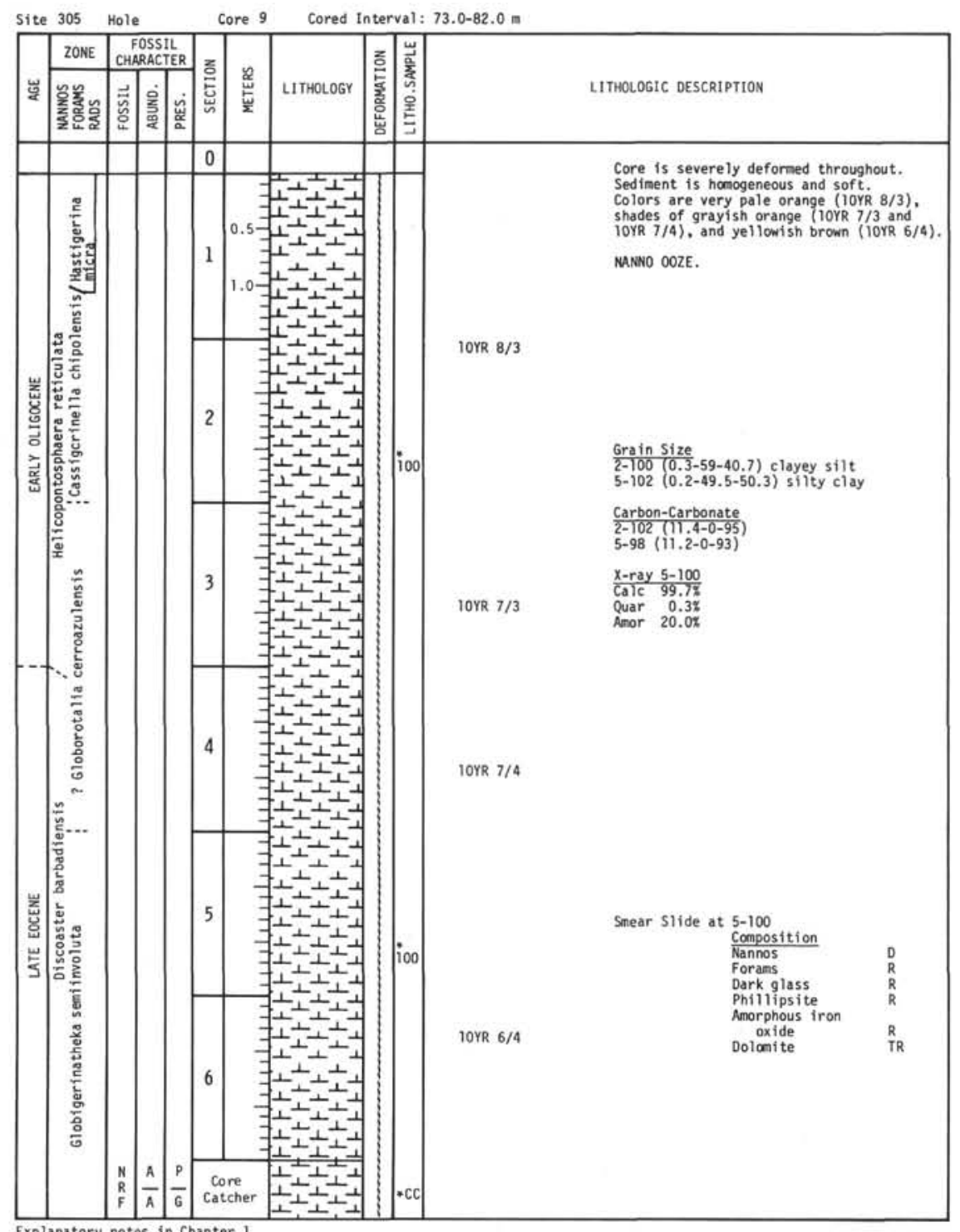




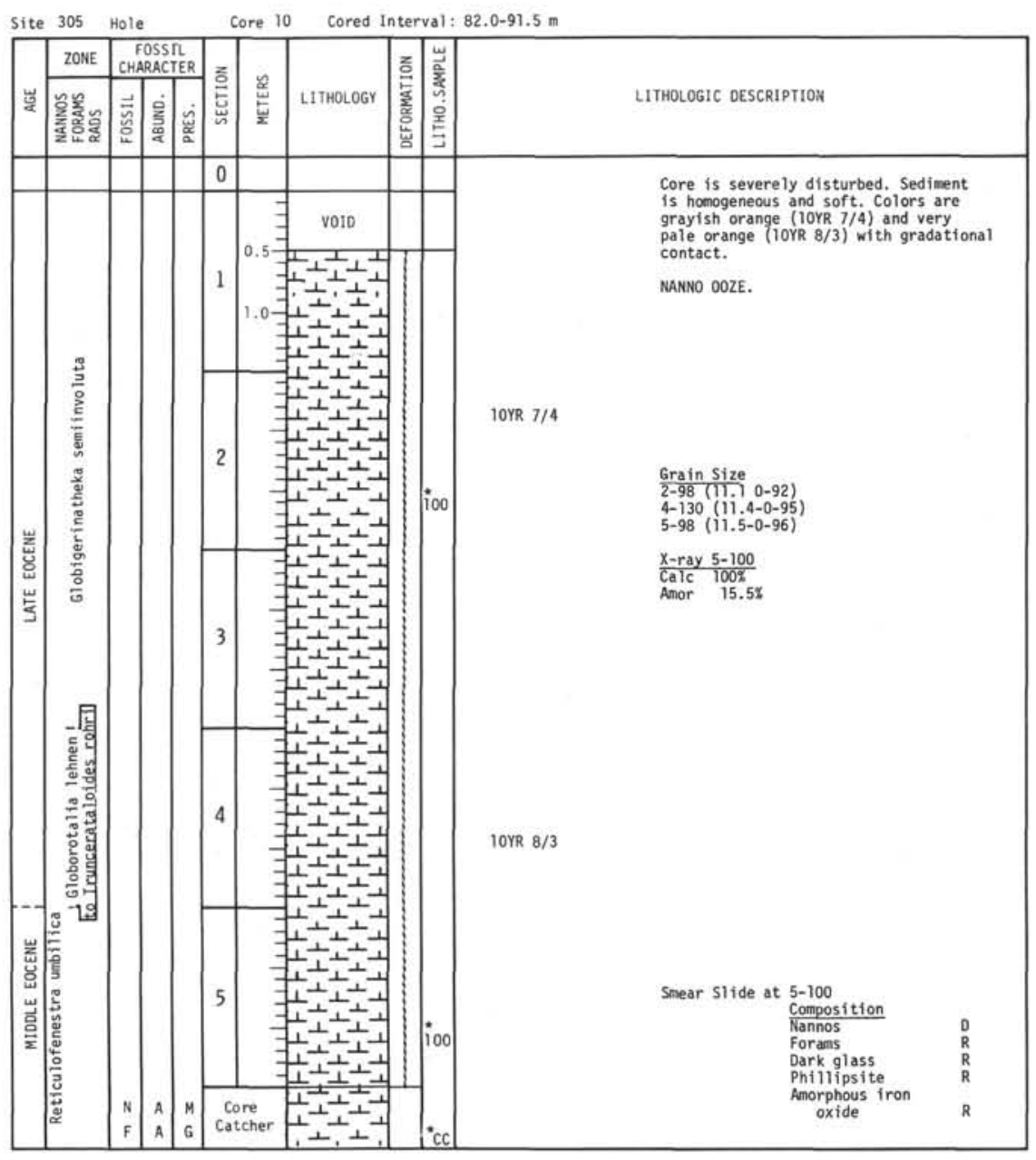

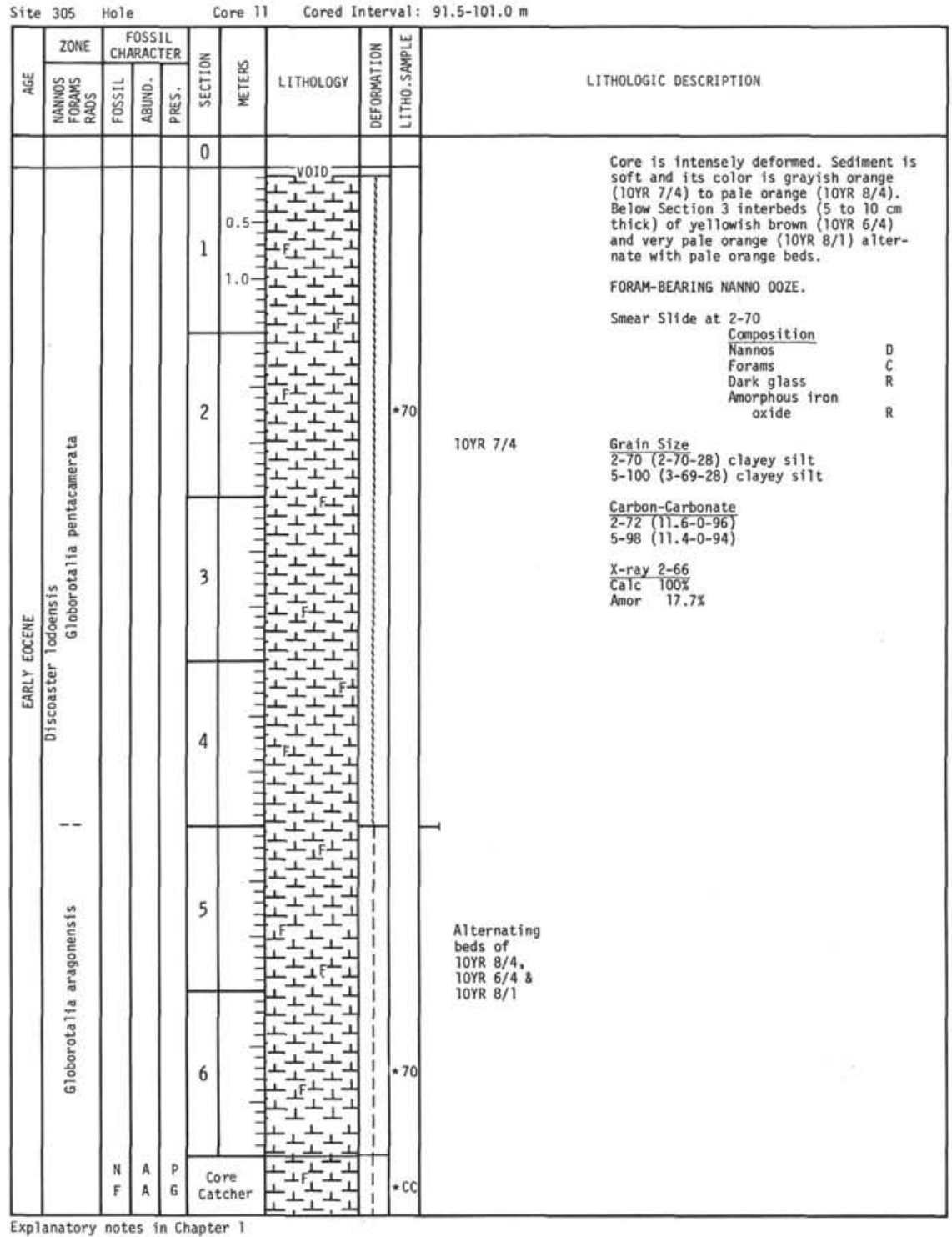




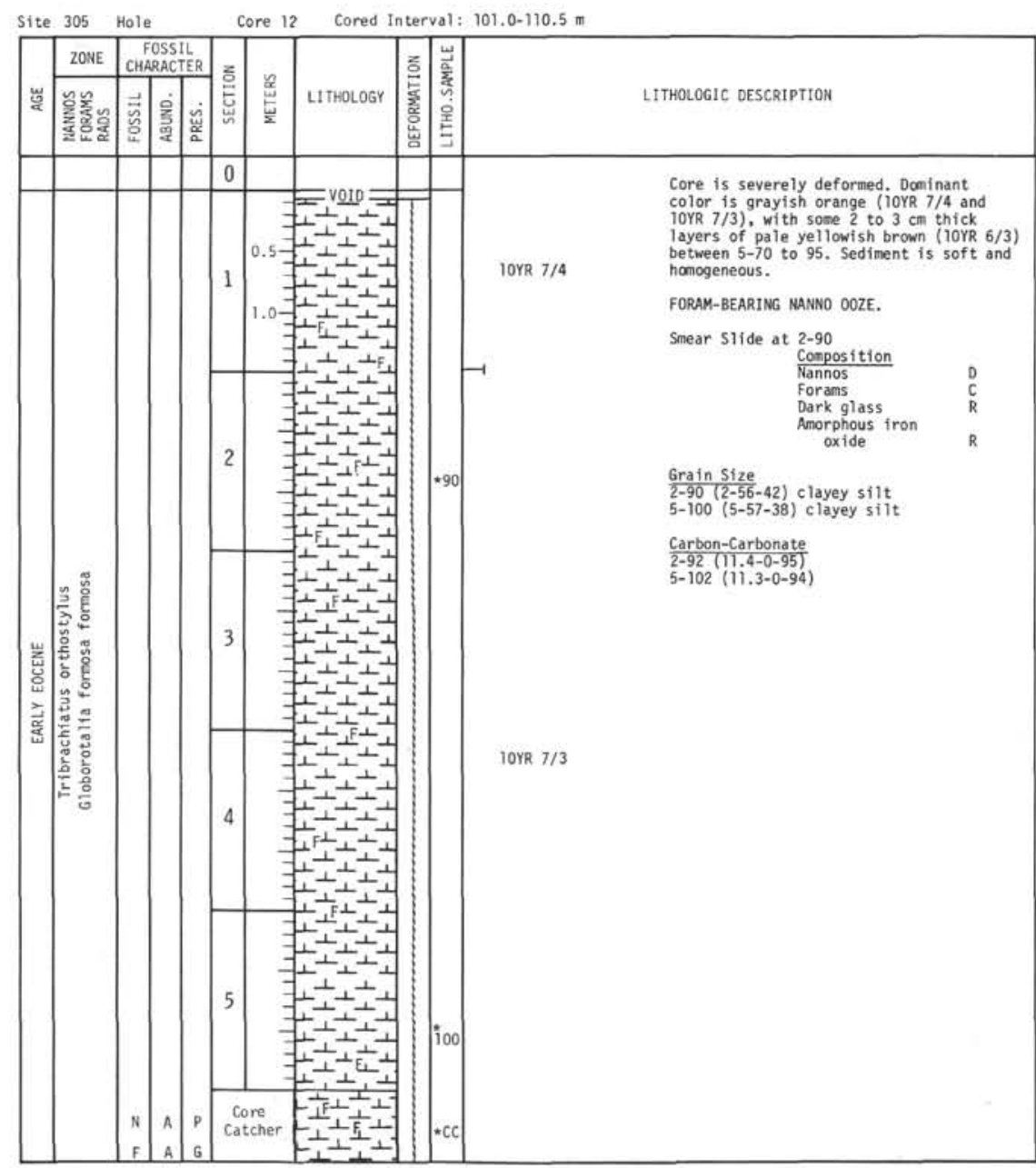

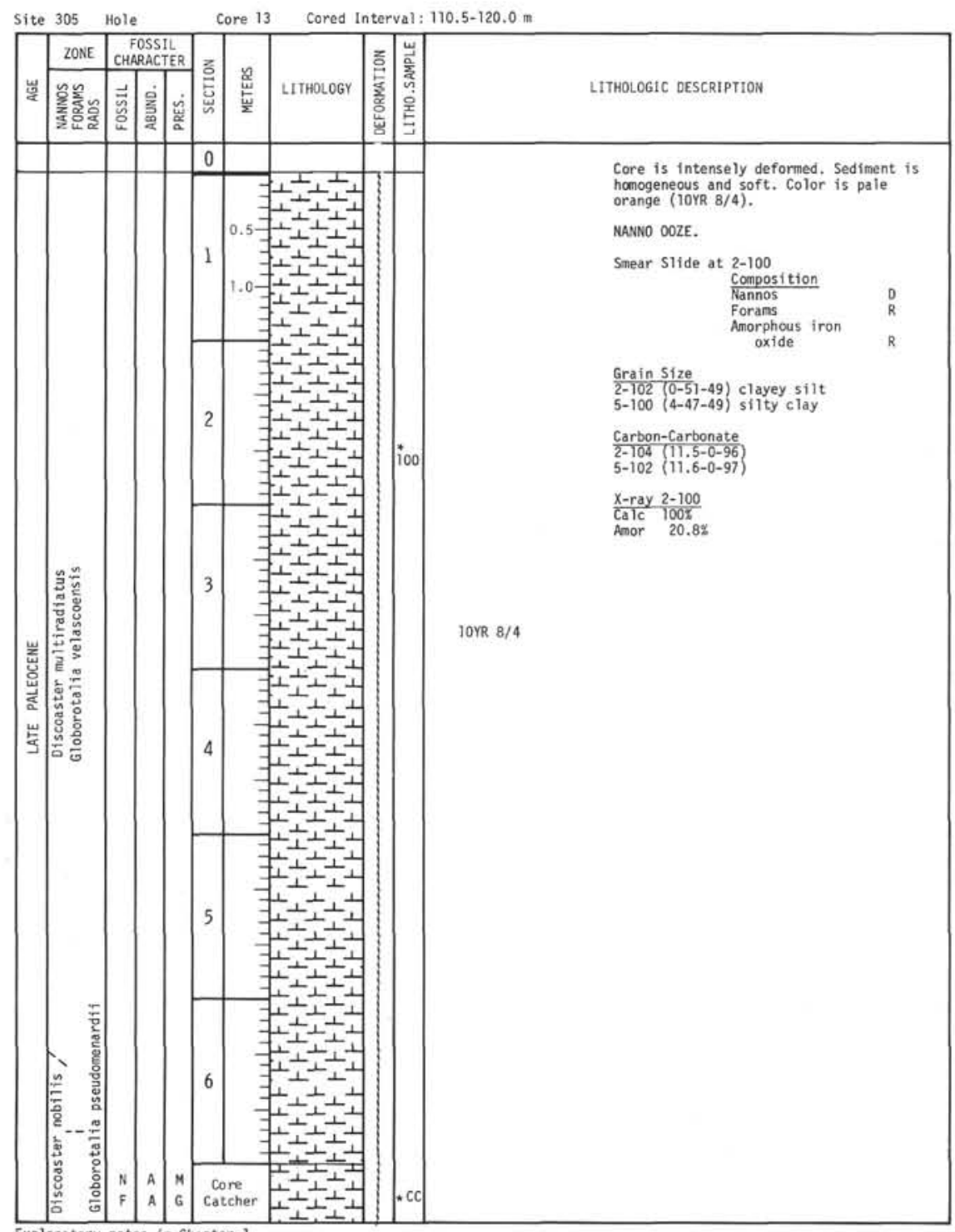




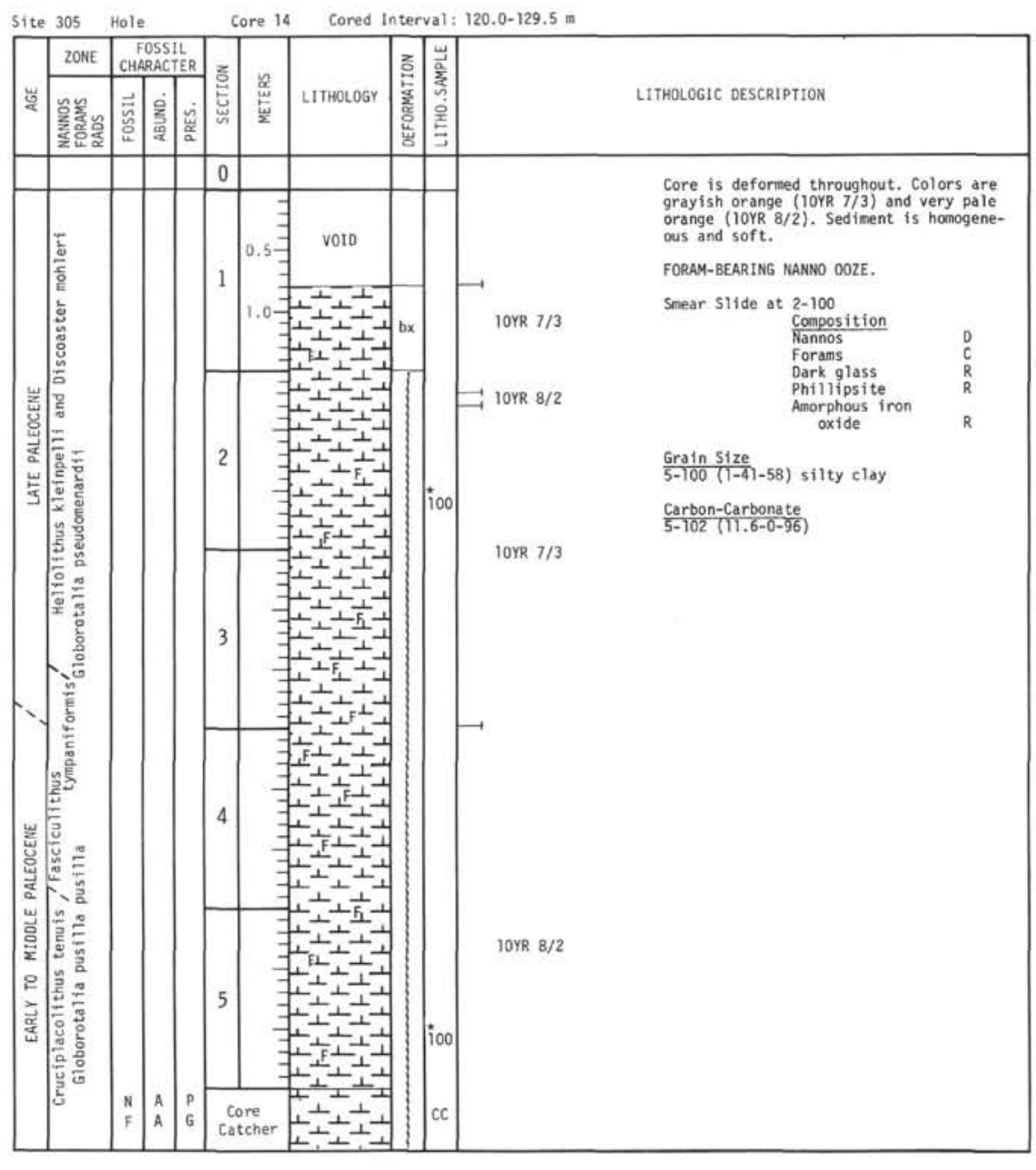

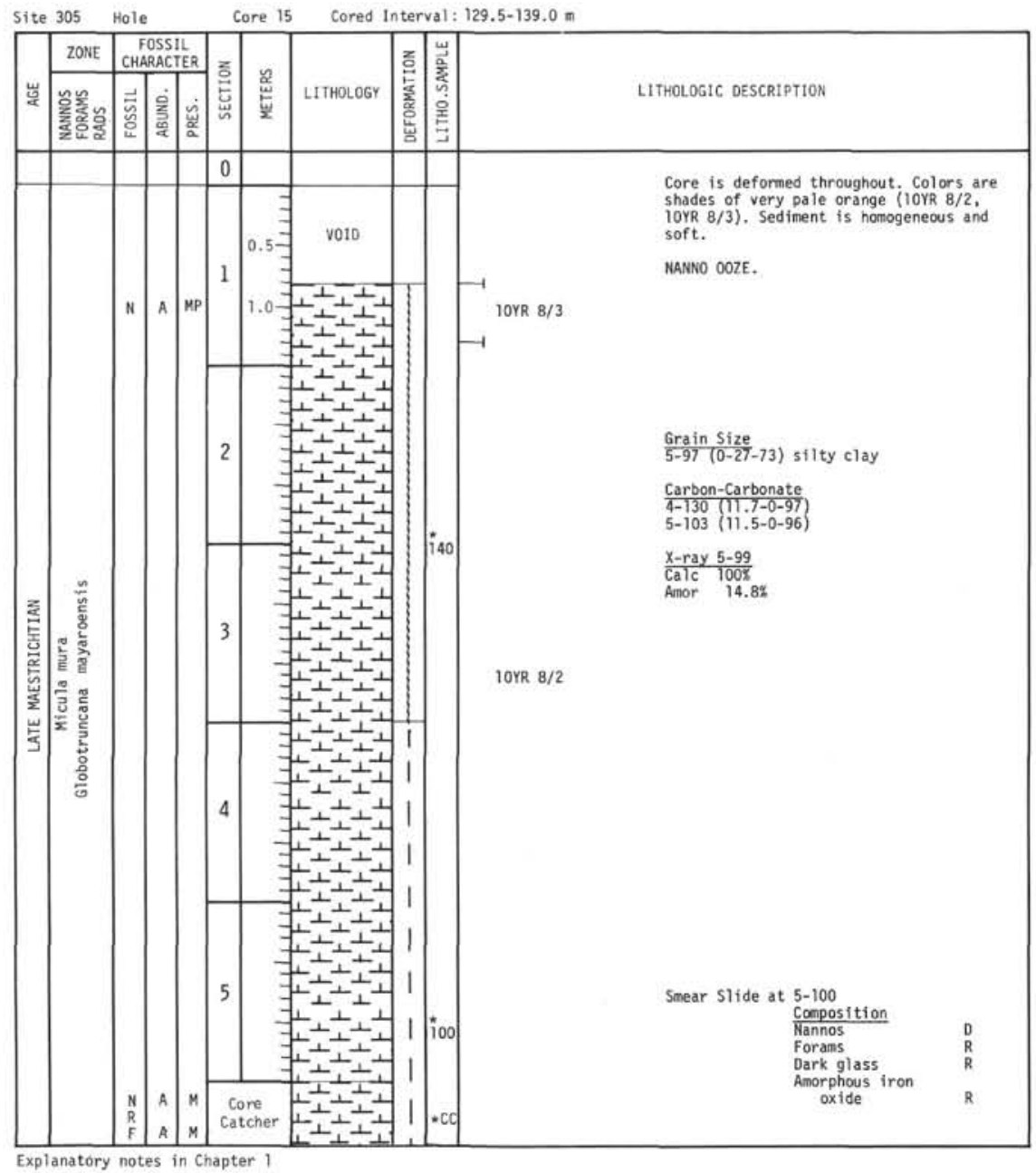




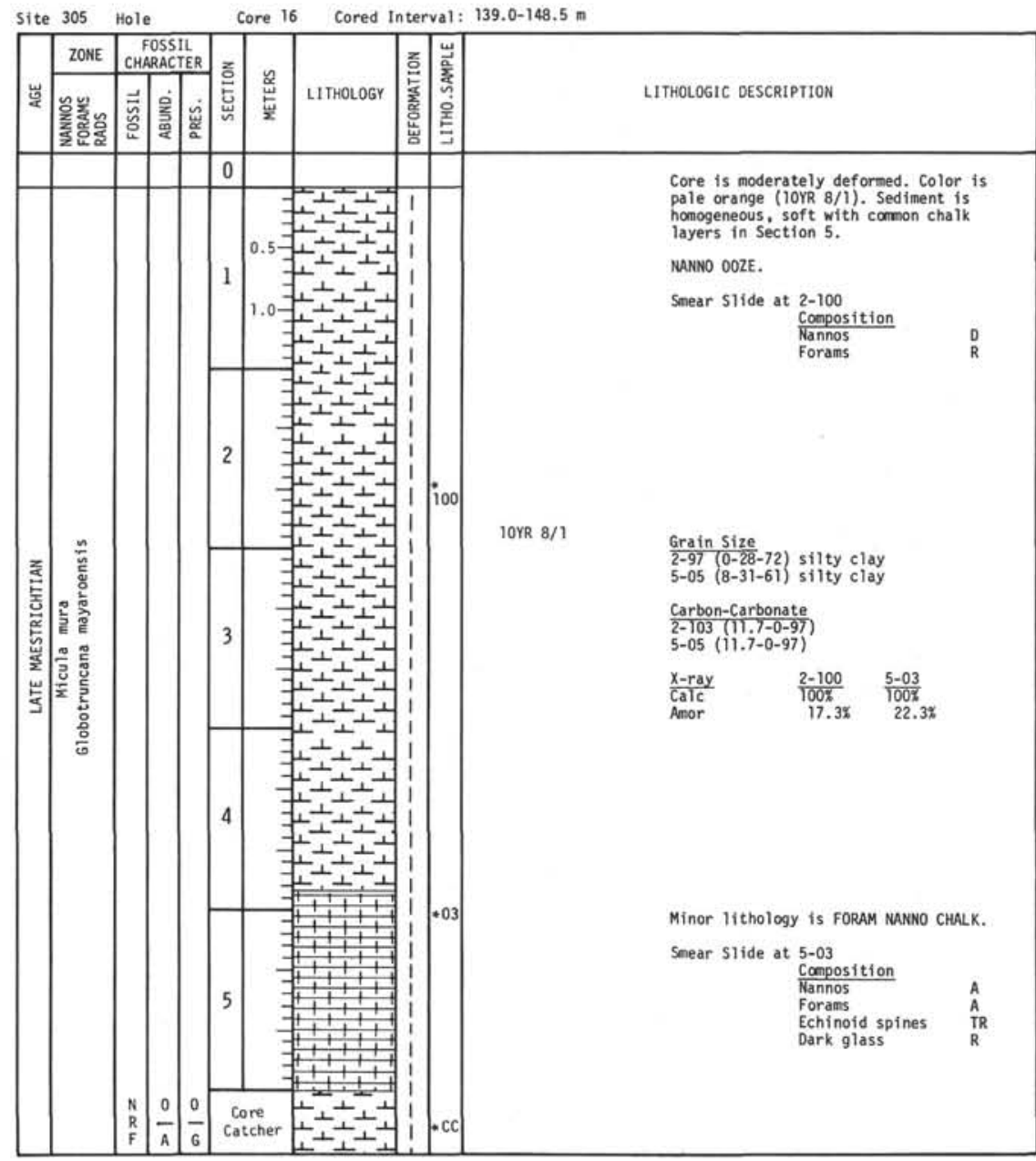

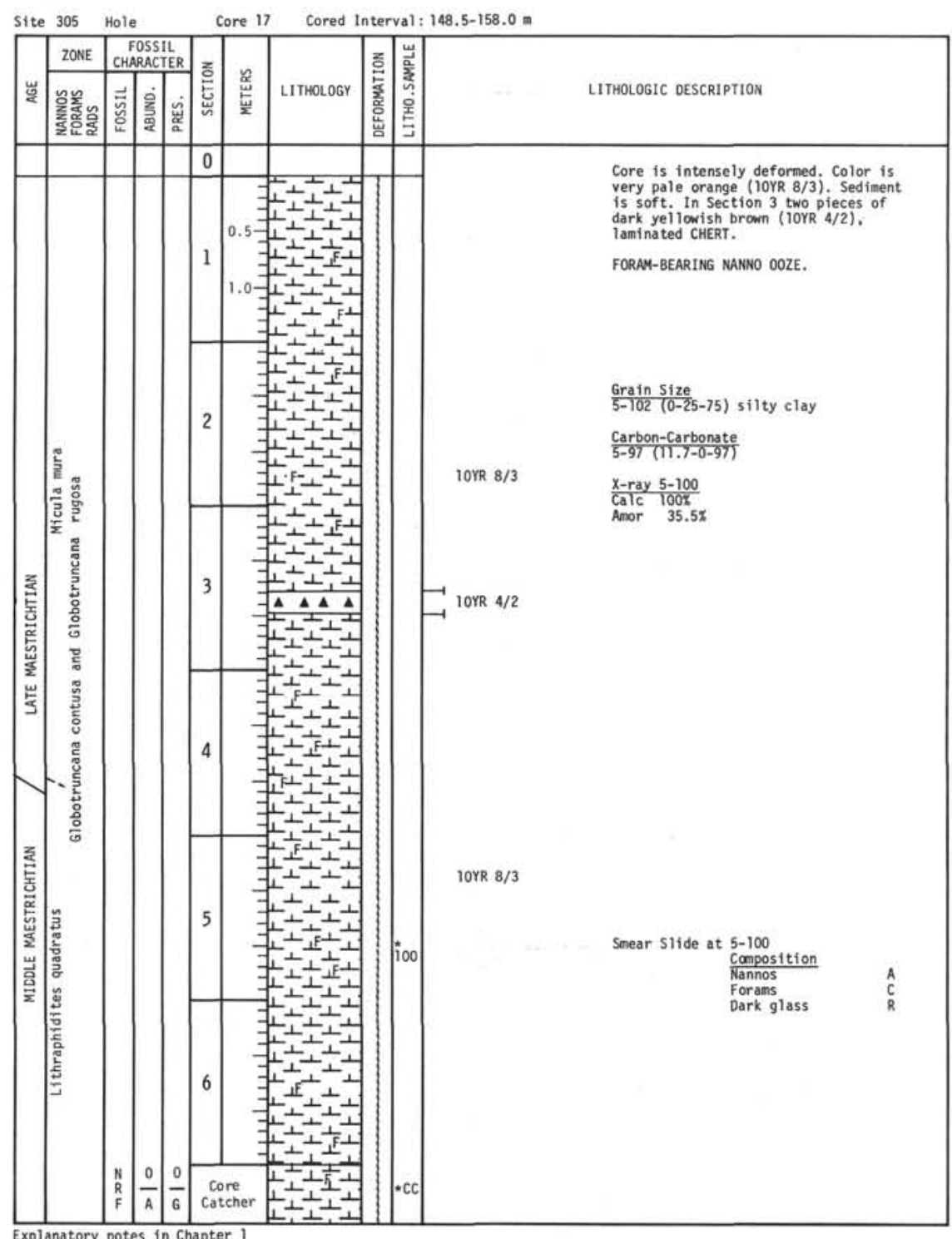




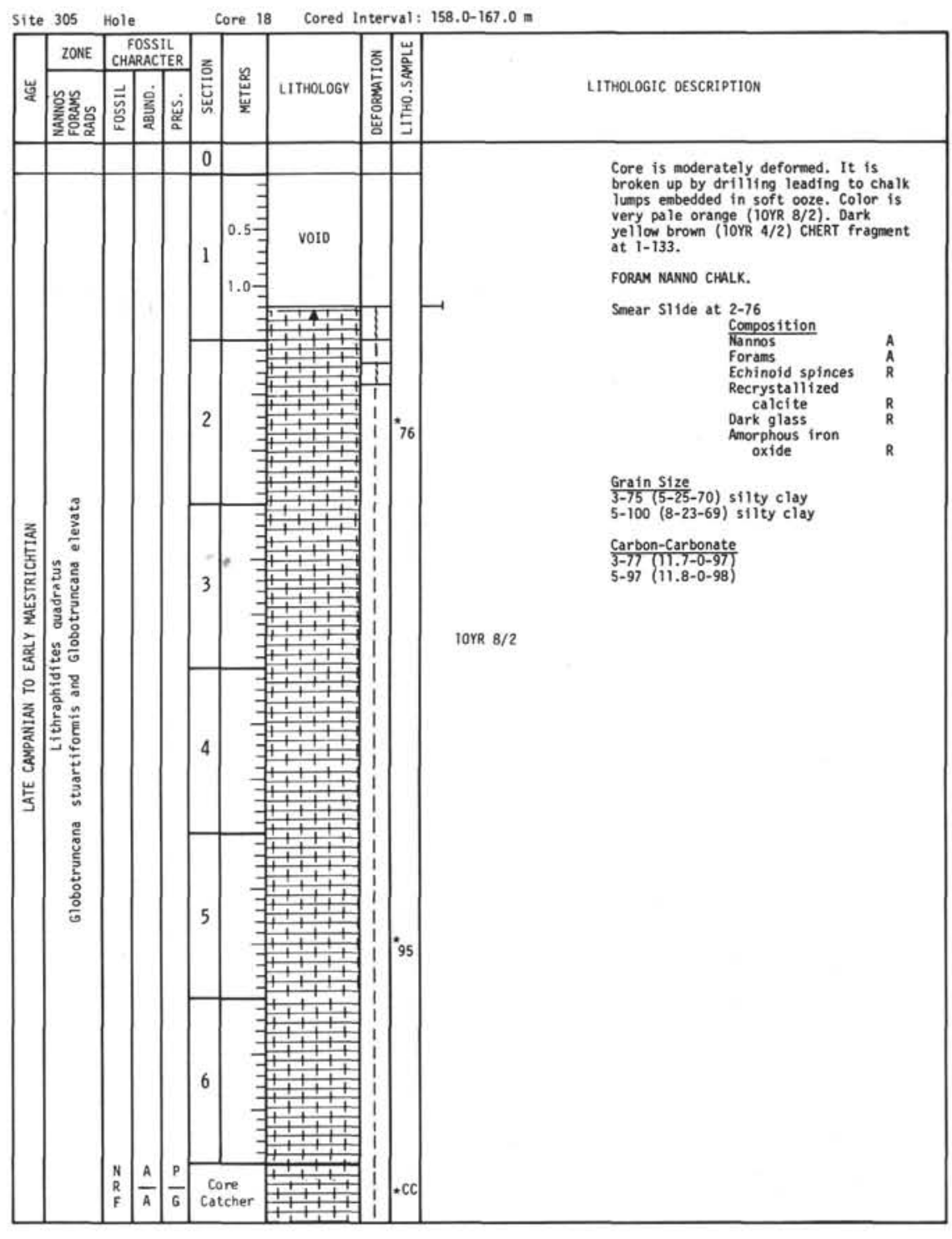

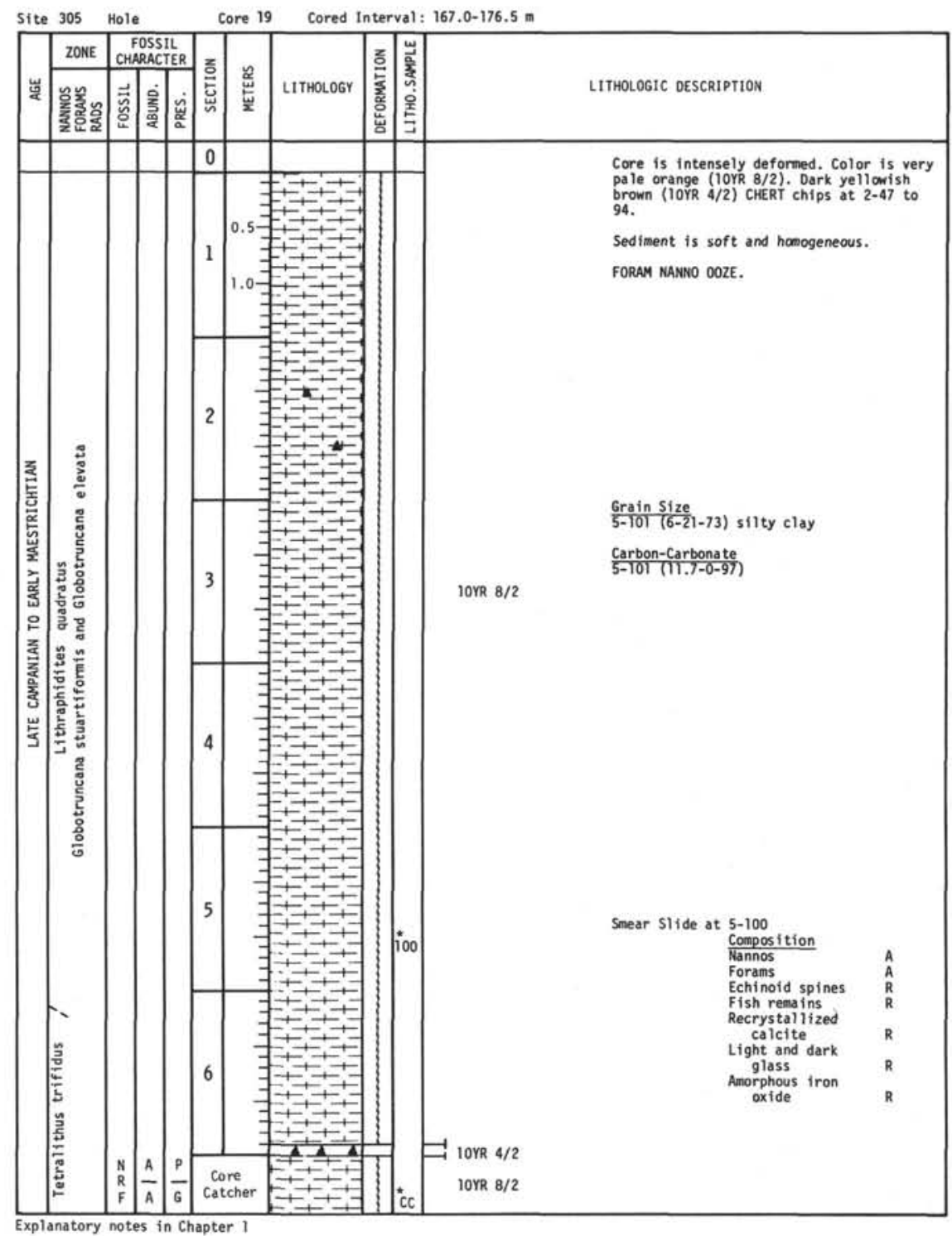




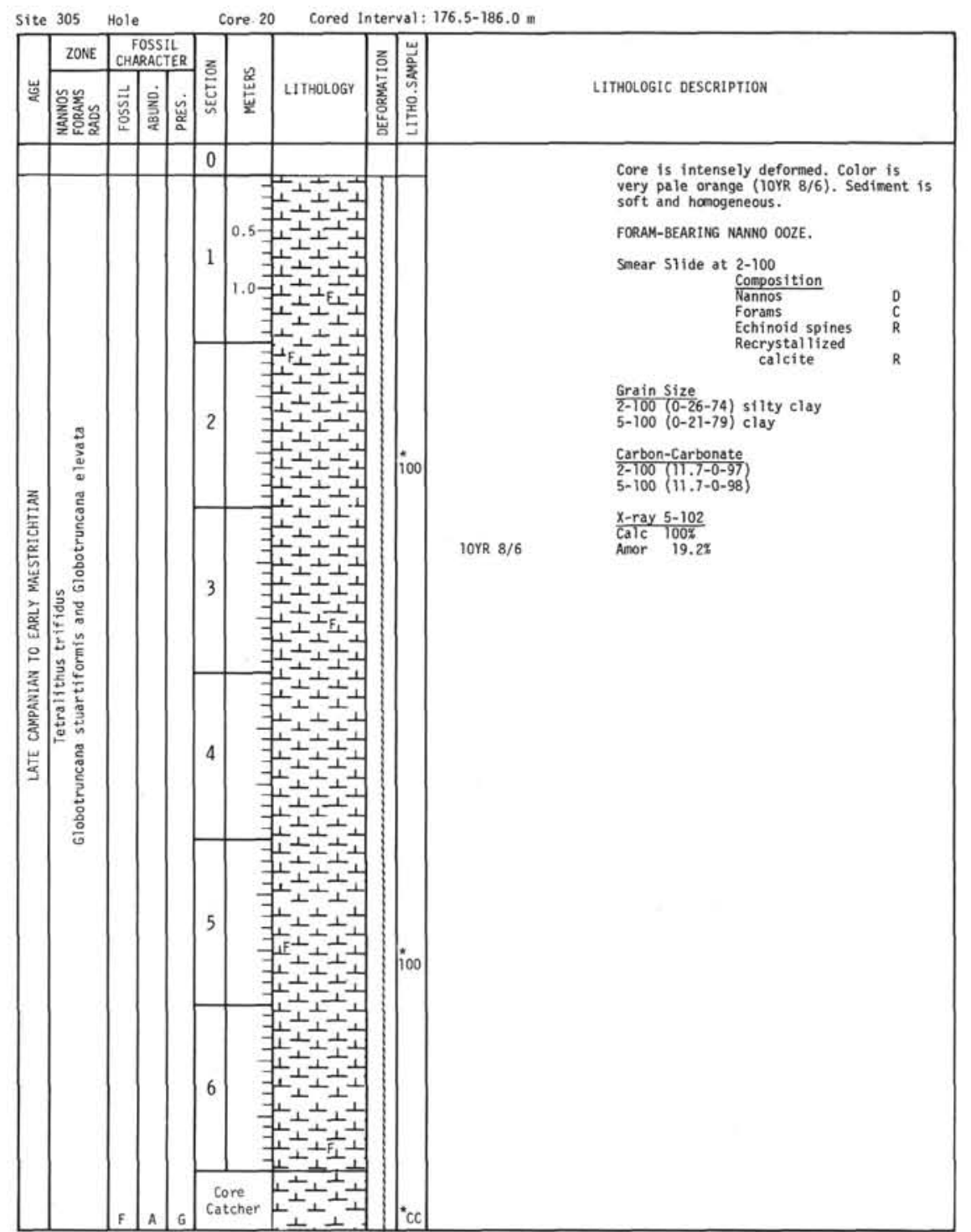

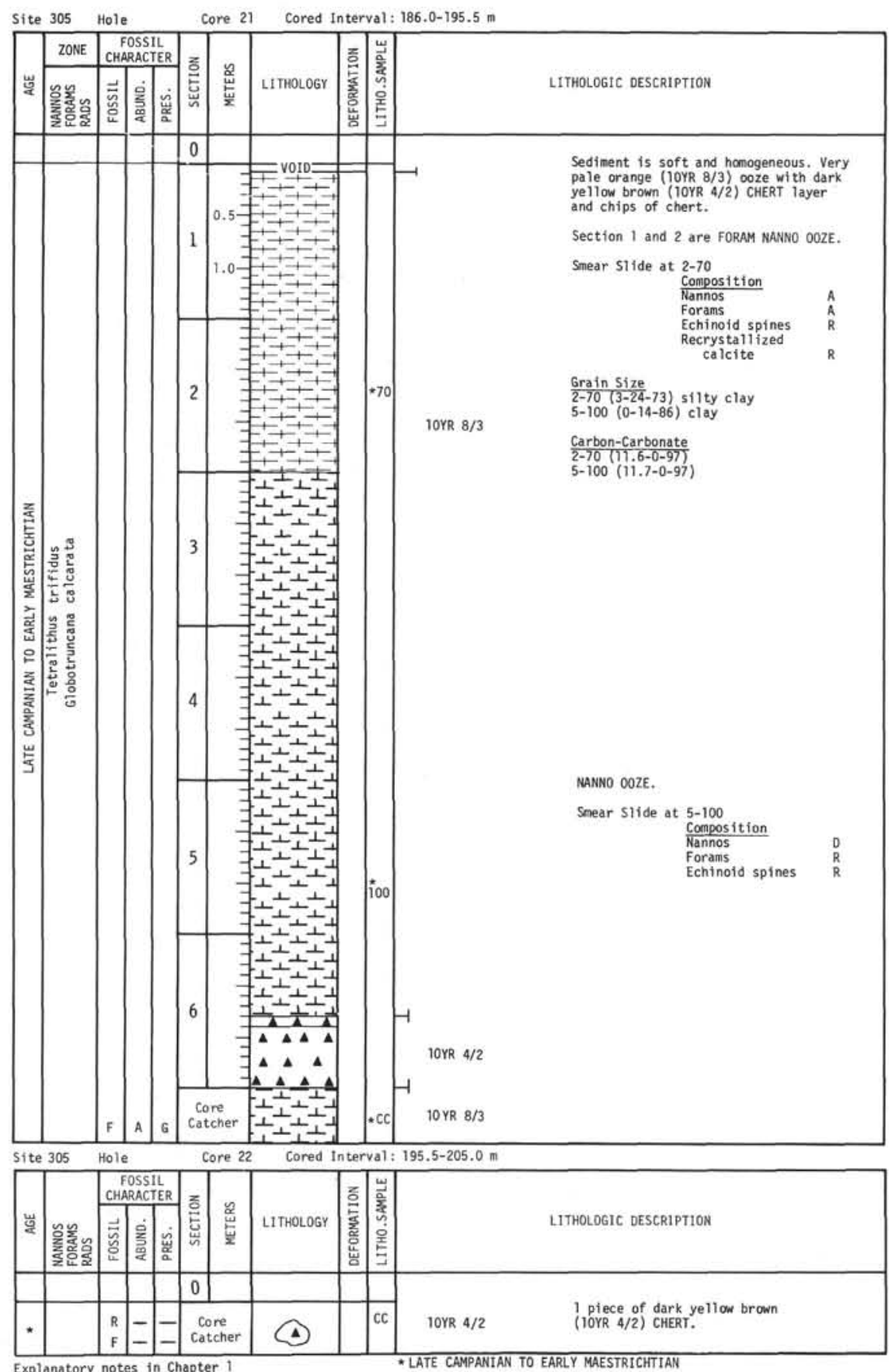

core is intensely deformed. Color is
very pale orange (ifork $8 / 6)$. Sesiment is FORAM-BEARING NANNO 00Z

ear slide at 2-100 Nampos
Forams
Echinoid

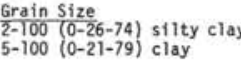

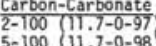
C-ray 5-102 Explanatory notes in Chapter 1 


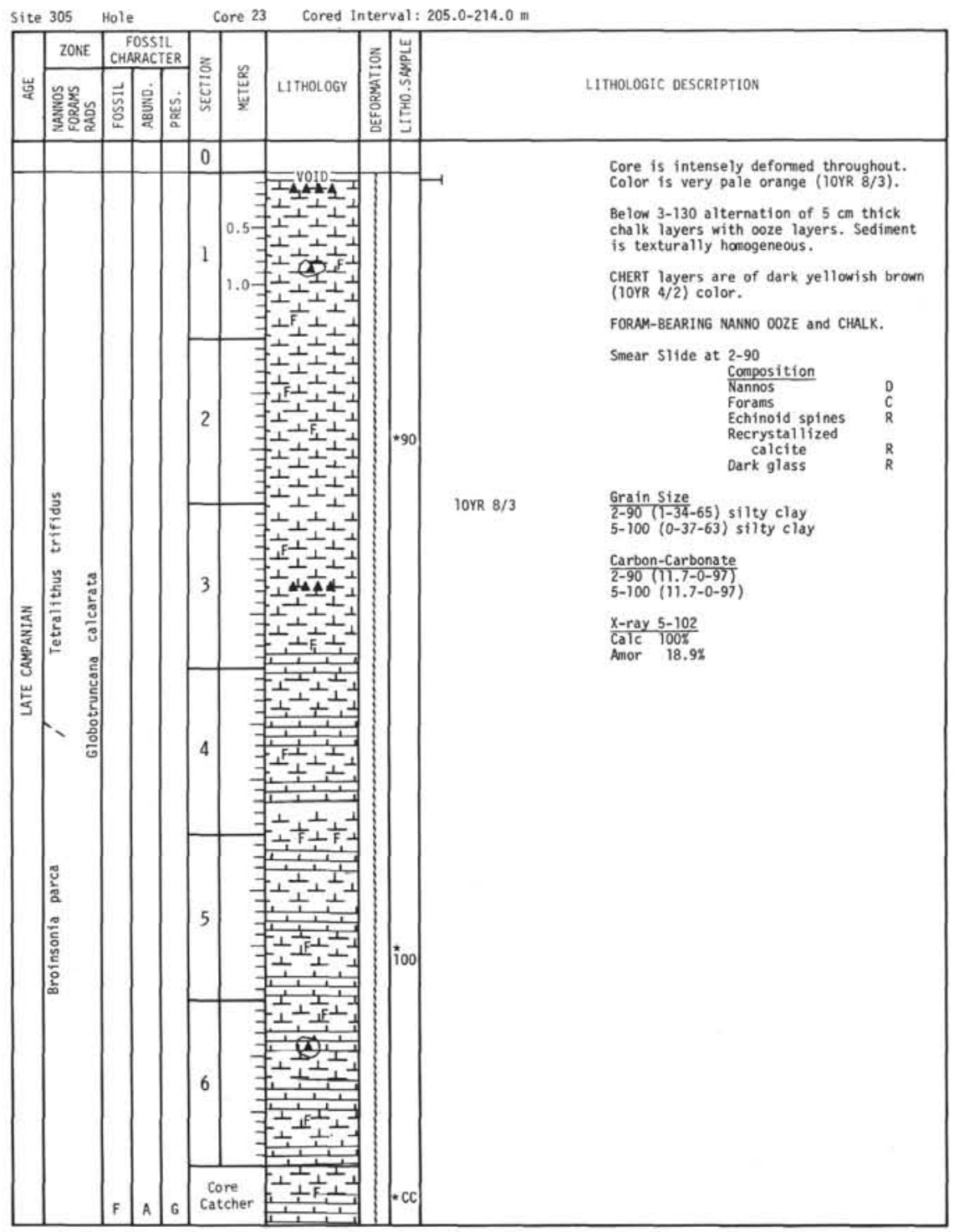

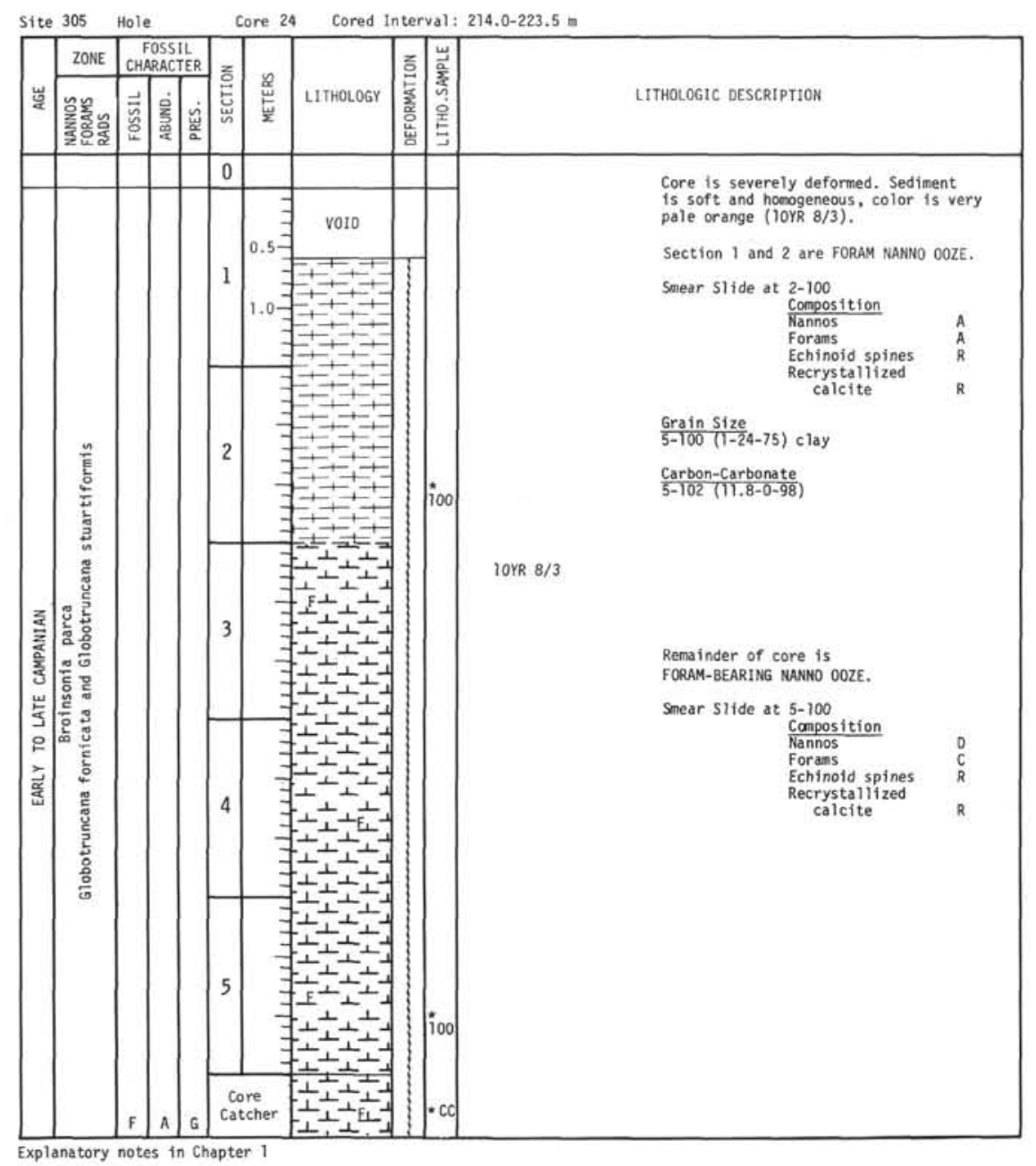




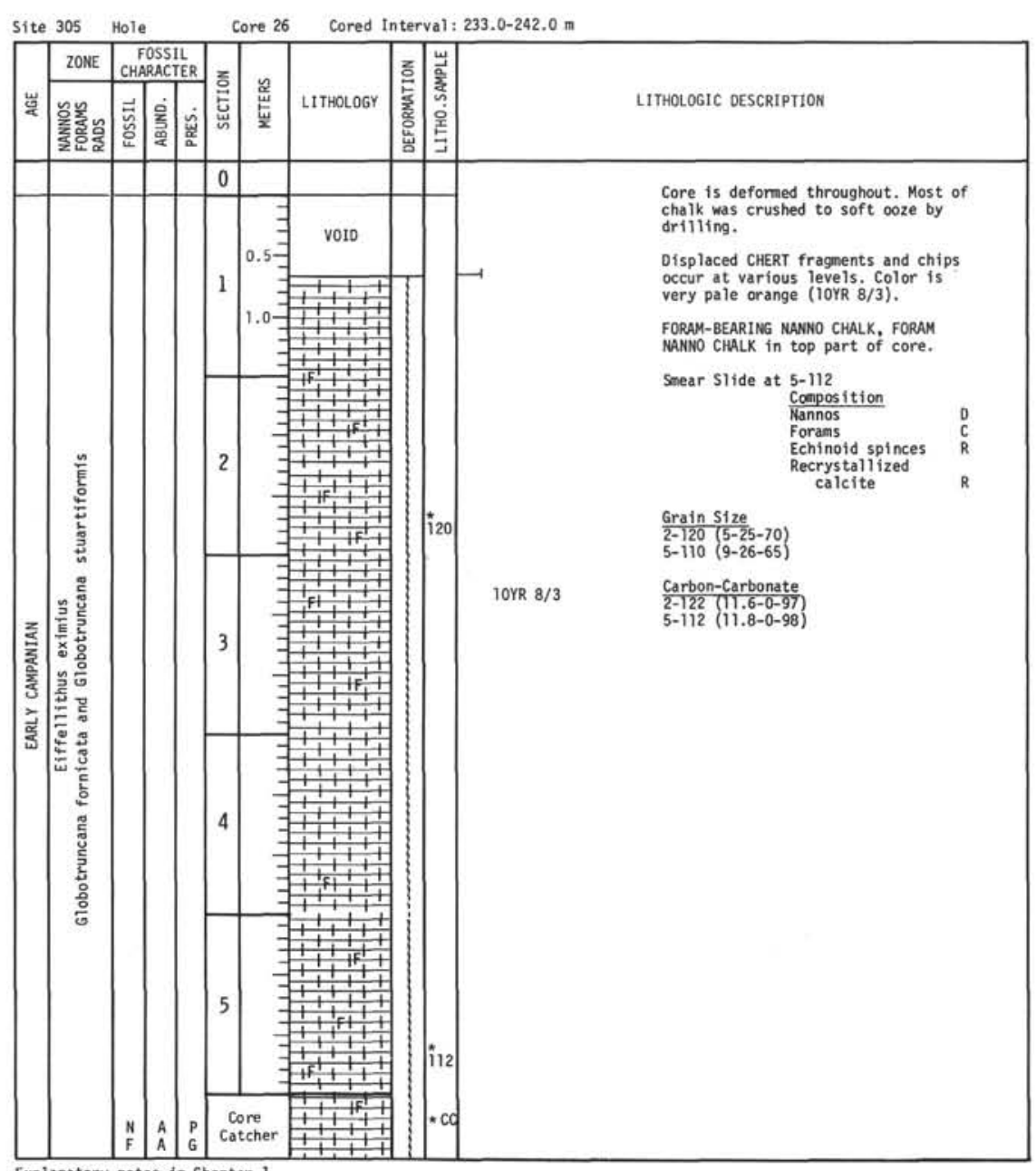




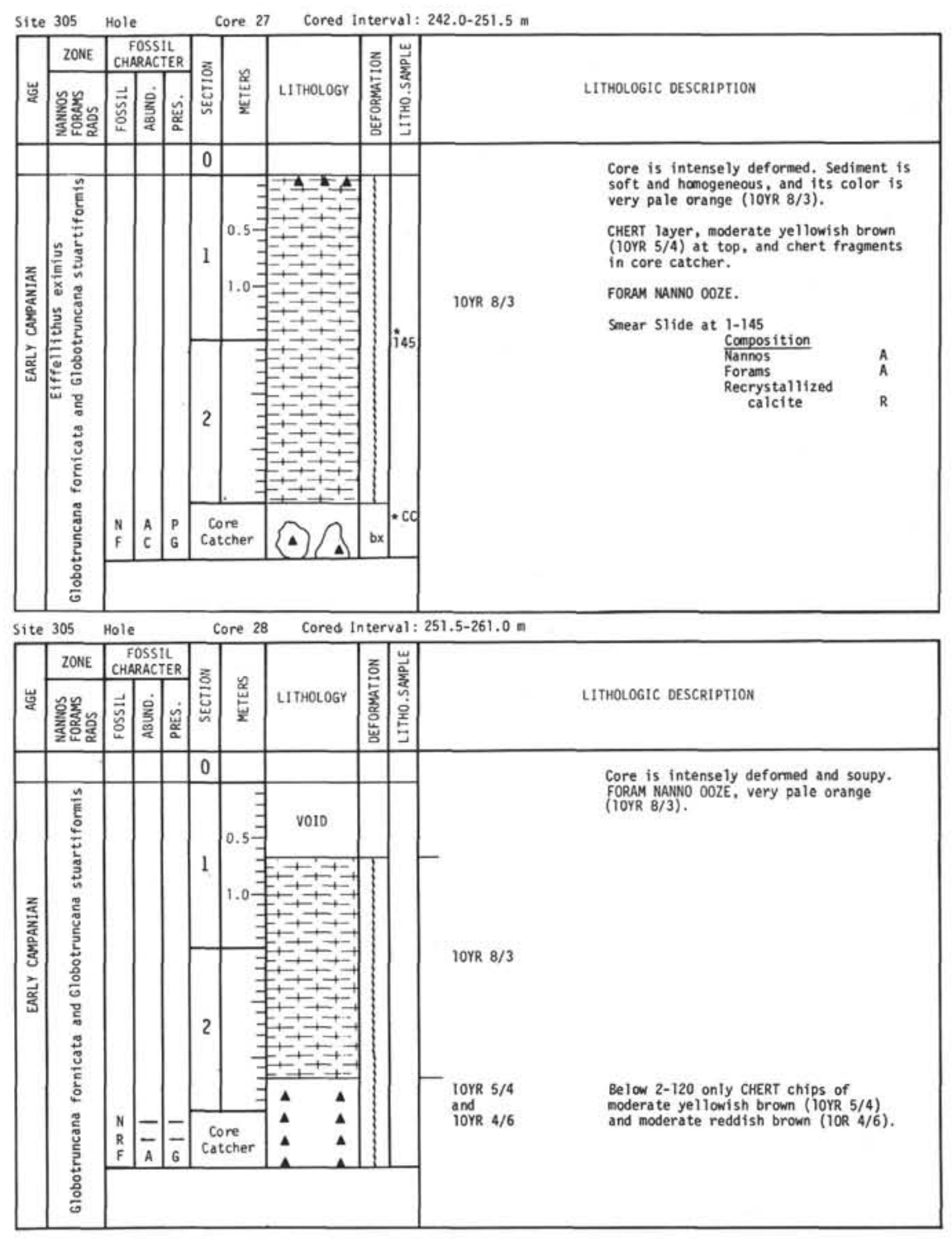
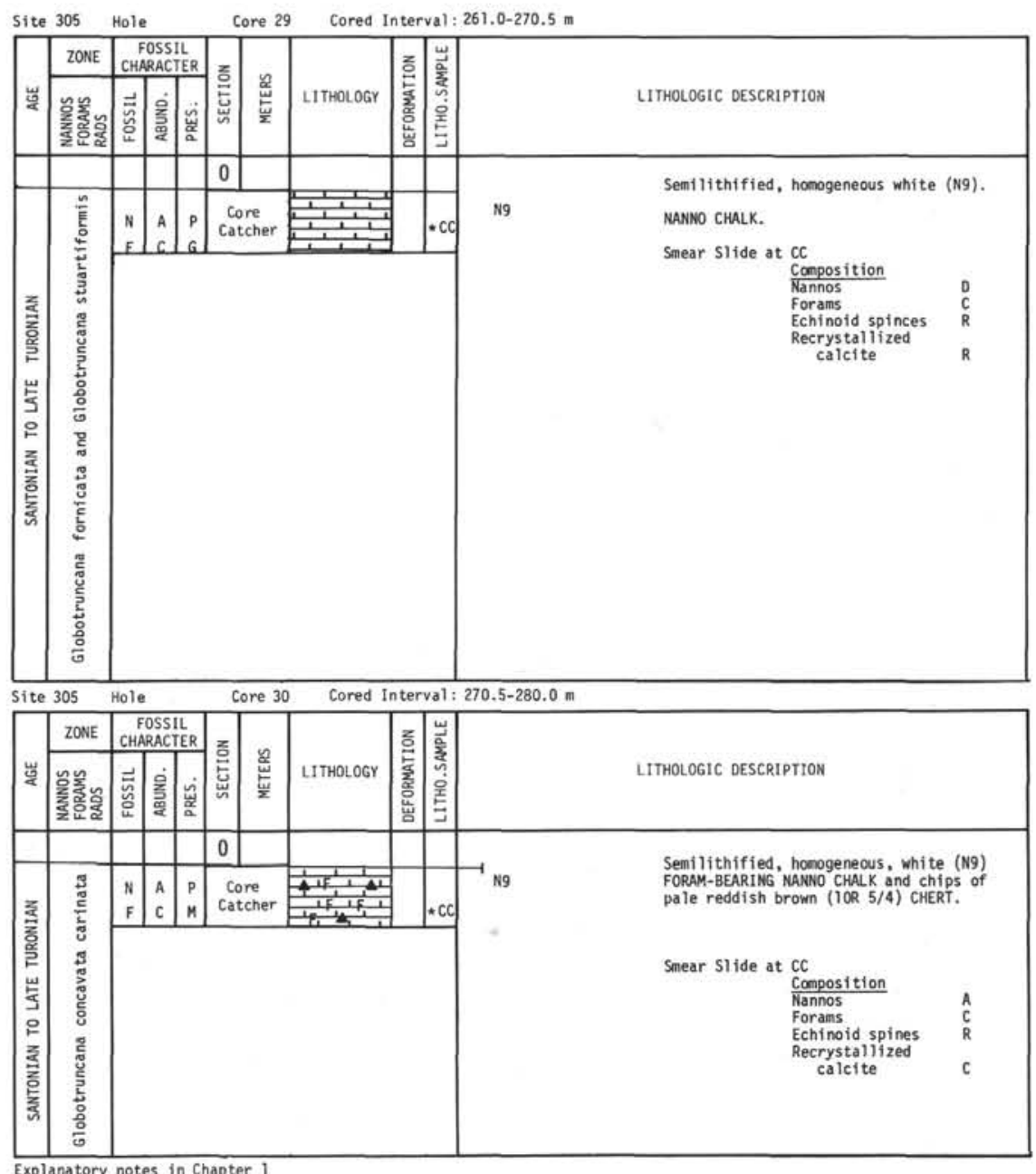
Site 305 Hole Core 33 Cored Interval: $298.5-308.0 \mathrm{~m}$

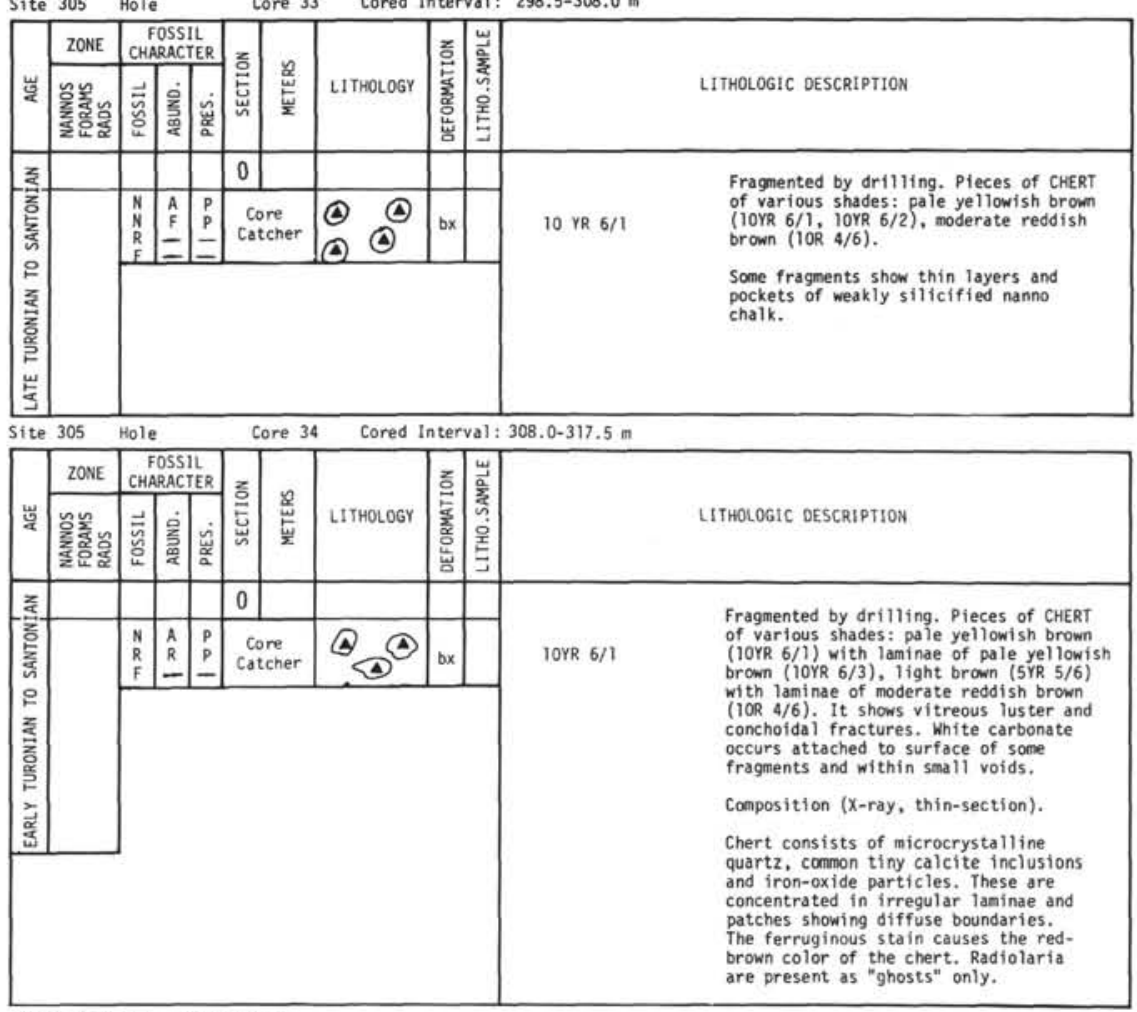

LITHOLOGIC OESCRIPTION

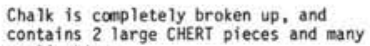
small chips.

FORAM NANNO CHALK, white (N9) and chert is moderate reddish brown
medium light gray $(2.5 Y$ 6
(1)

Smear slide at

$$
\begin{aligned}
& \text { Composition } \\
& \text { Rannos } \\
& \text { Forams } \\
& \text { EChinoid spines } \\
& \text { Recrystallized } \\
& \text { calcite } \\
& \text { Dark glass }
\end{aligned}
$$




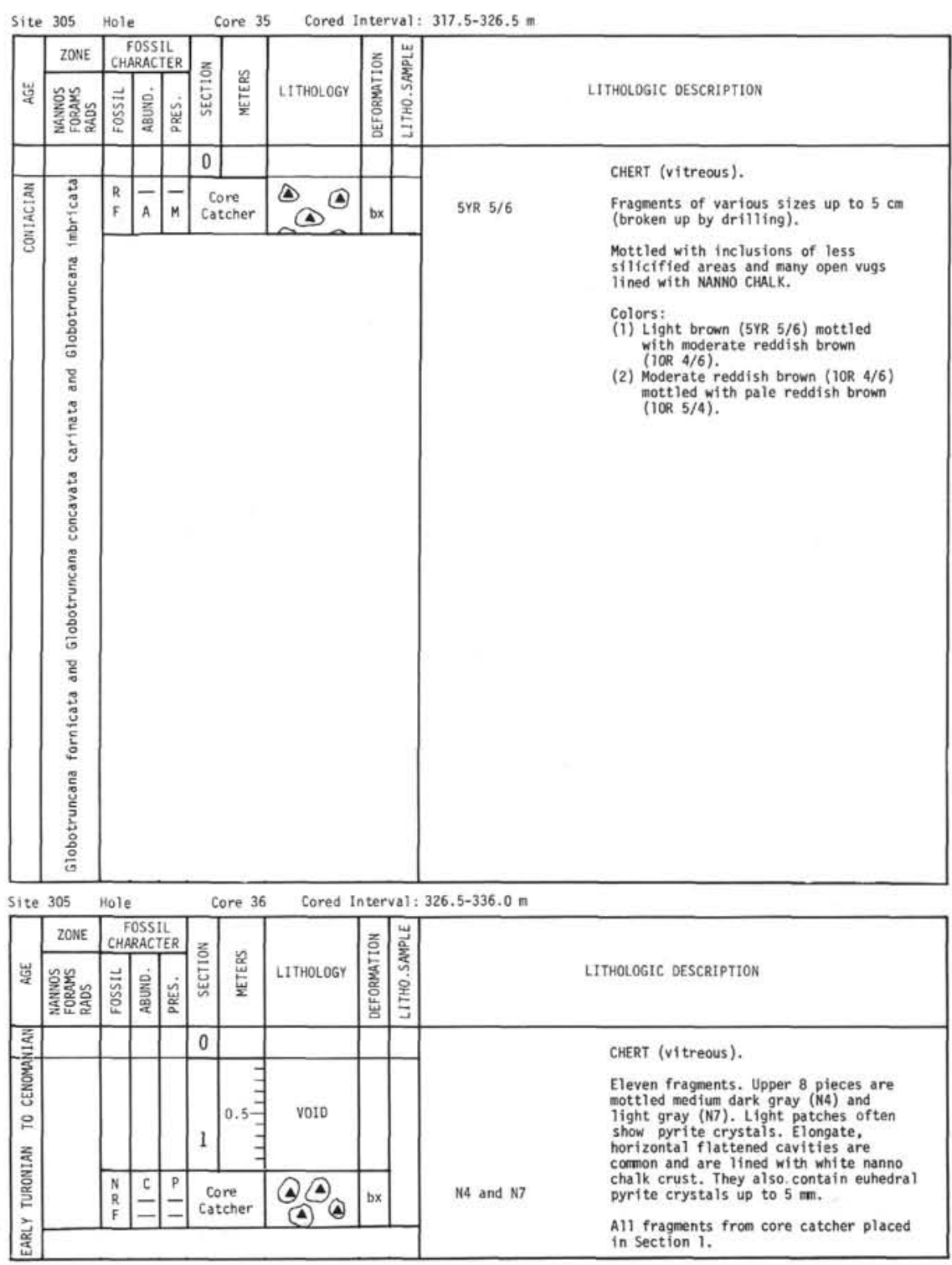

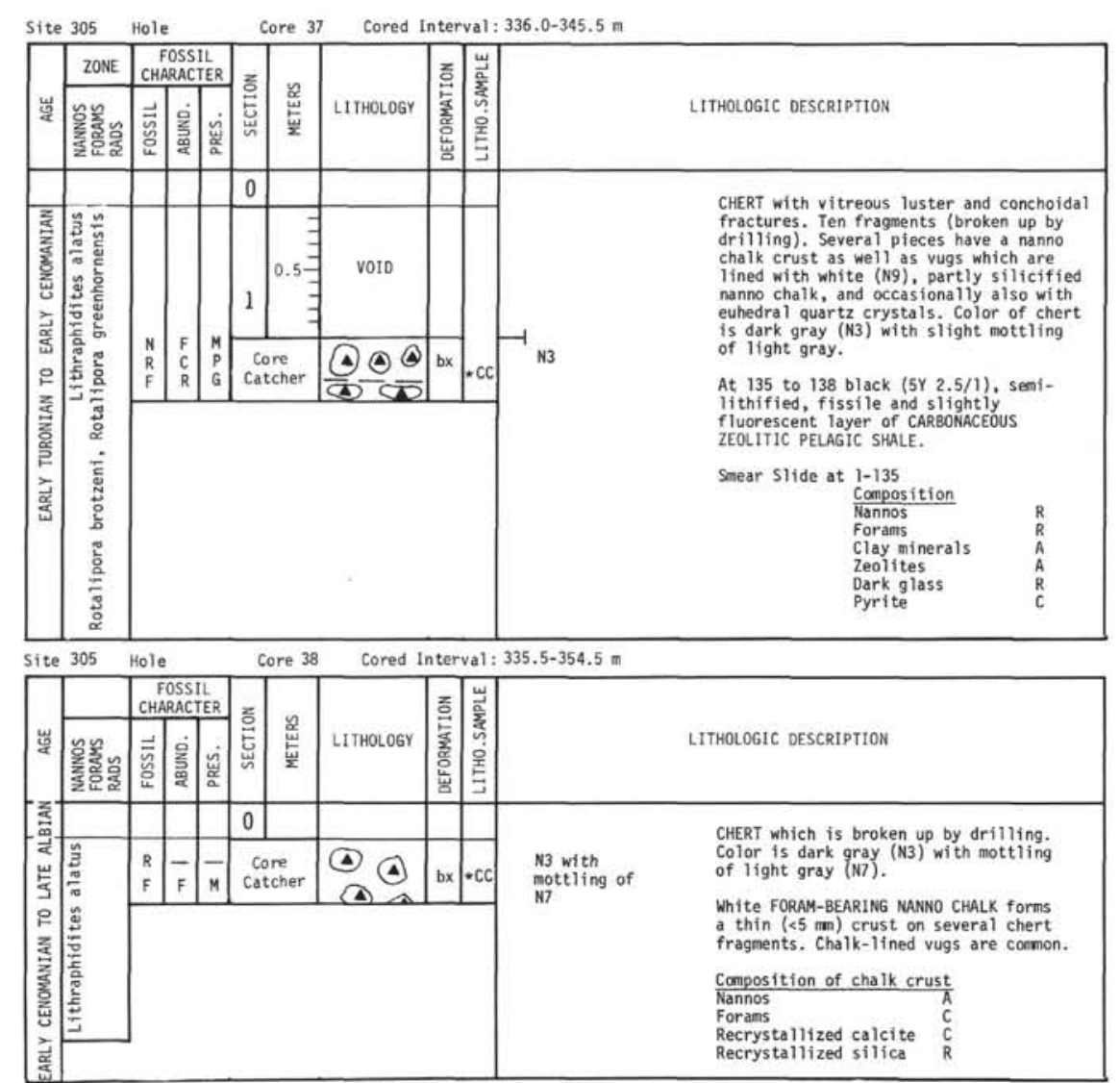

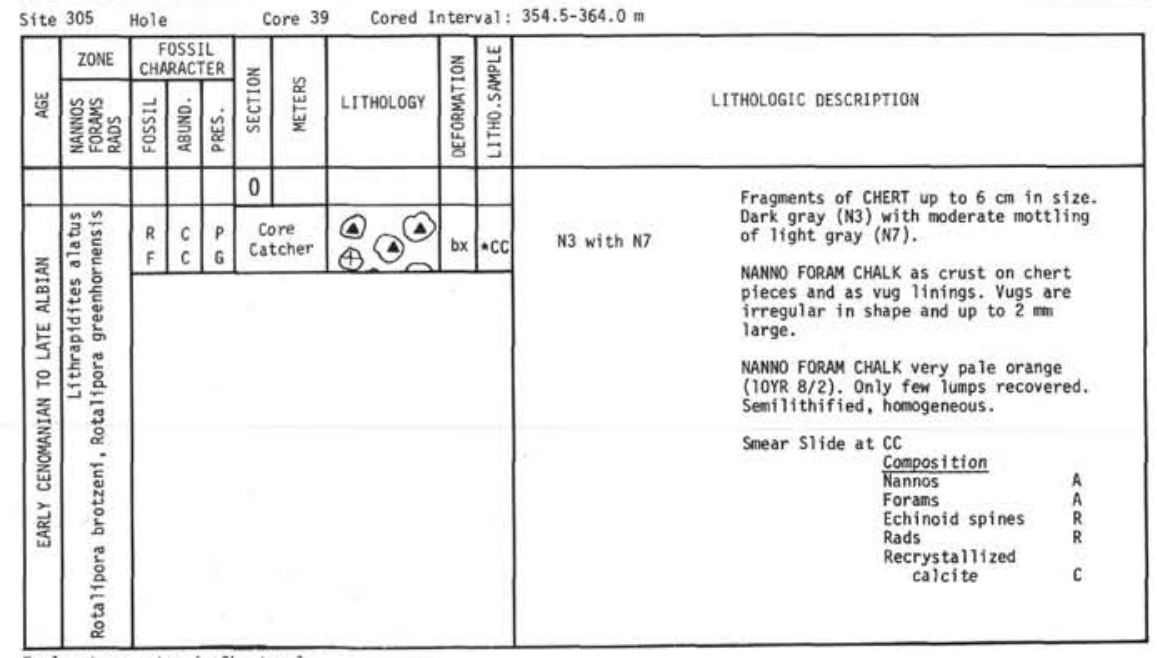


Site 305 Hole Core 42 Cored Interval: $382.5-391.5 \mathrm{~m}$

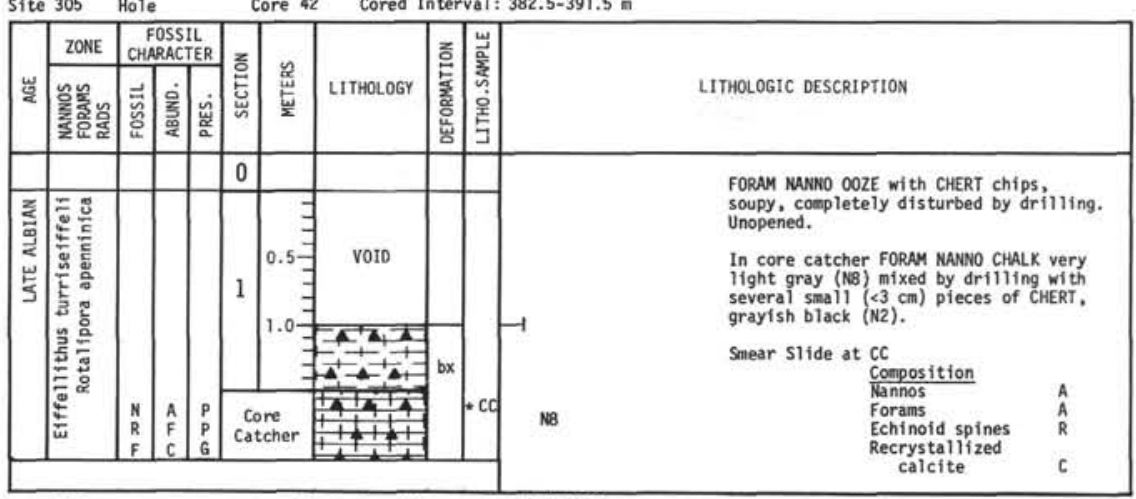

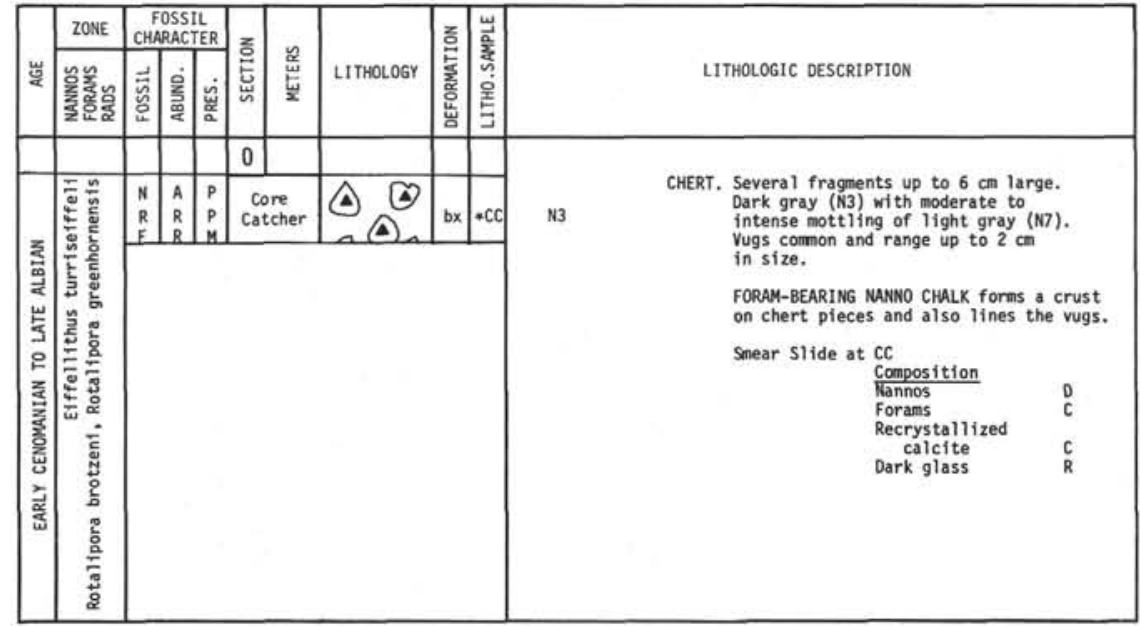

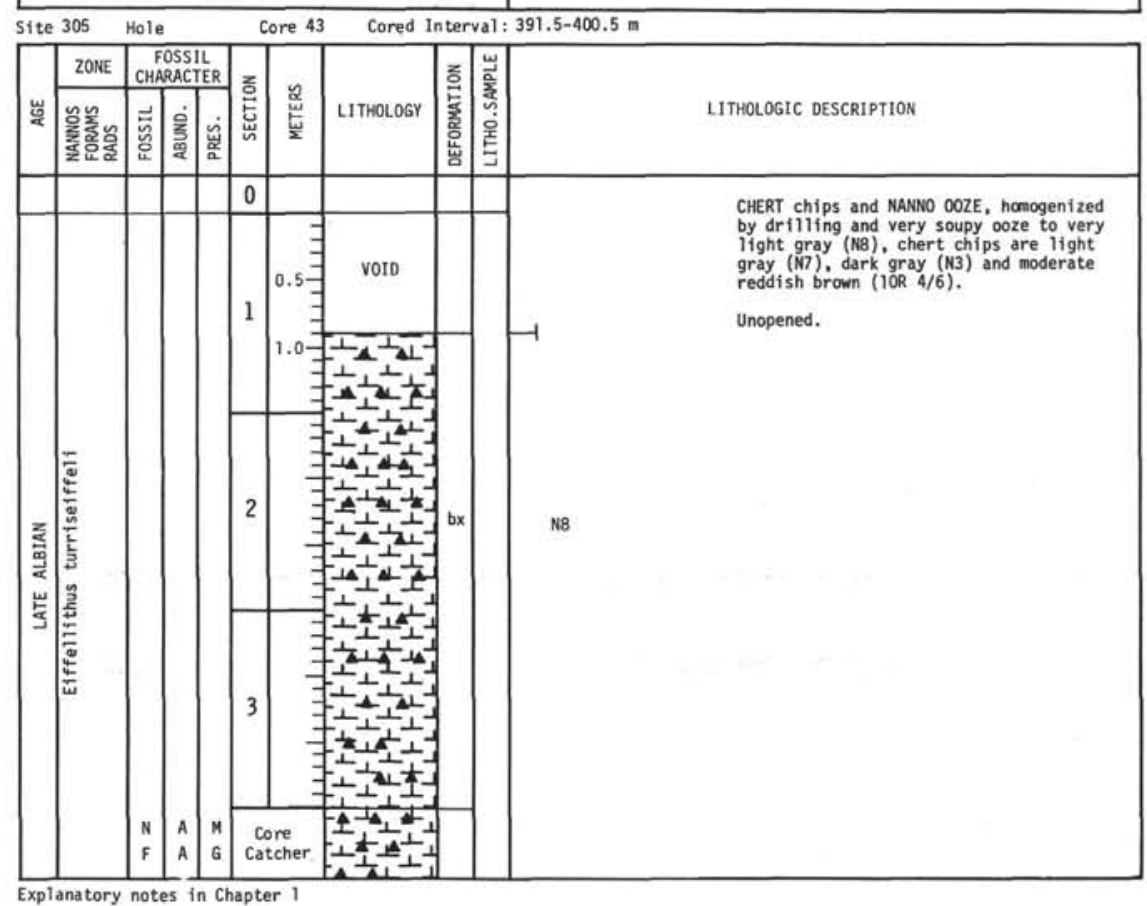




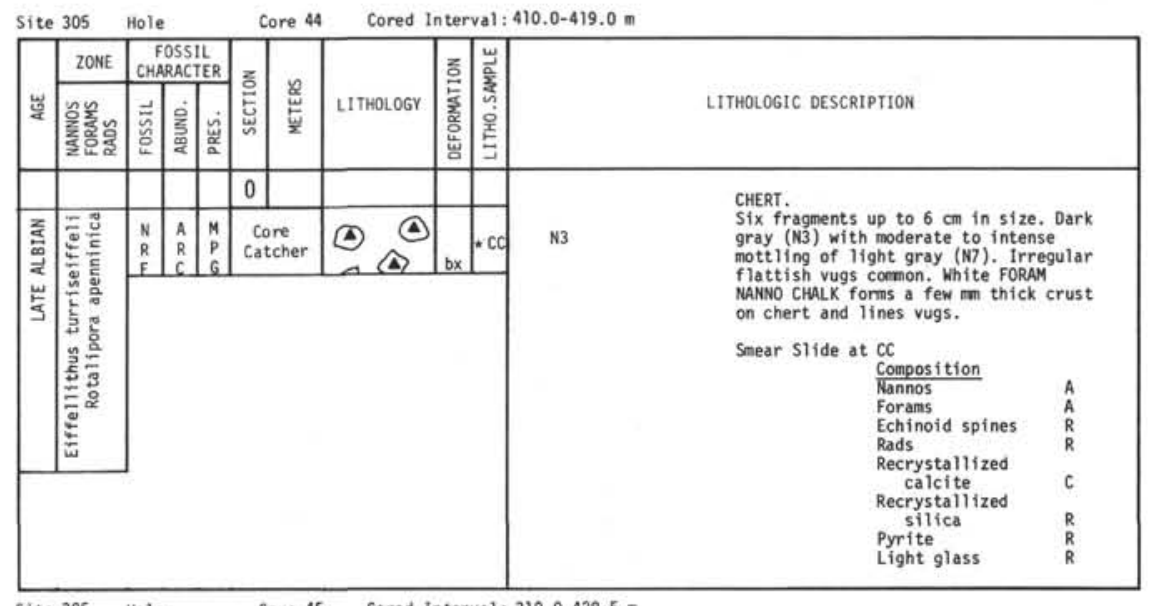

Site 305 Hole Core 47 Cored Interval: $438.0-447.5 \mathrm{~m}$

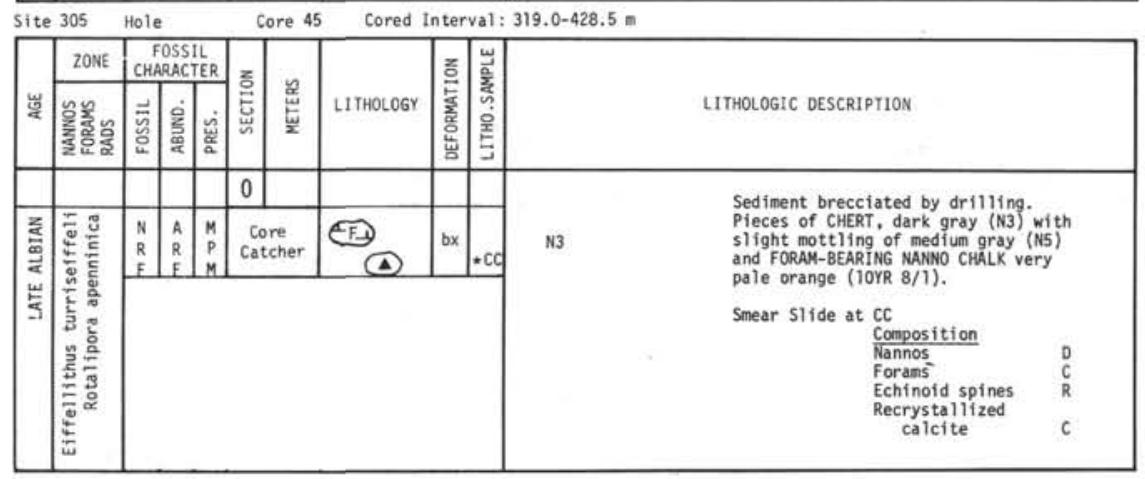

\begin{tabular}{|l|l|l|l|l|l|l|l|l|l|l|}
\hline Site 305 & Hole & \\
\hline
\end{tabular}

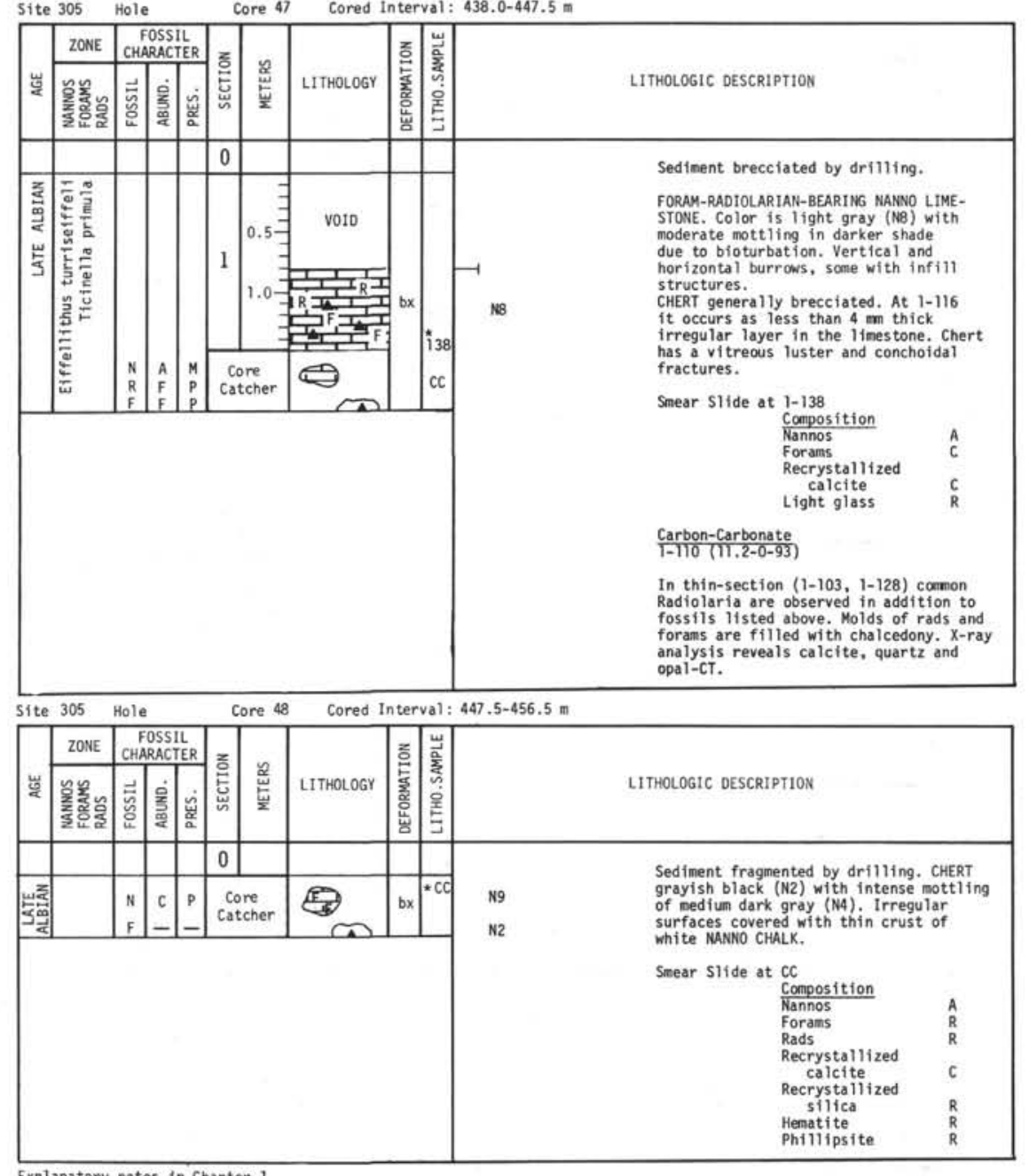

Explanatory notes in Chapter 1 

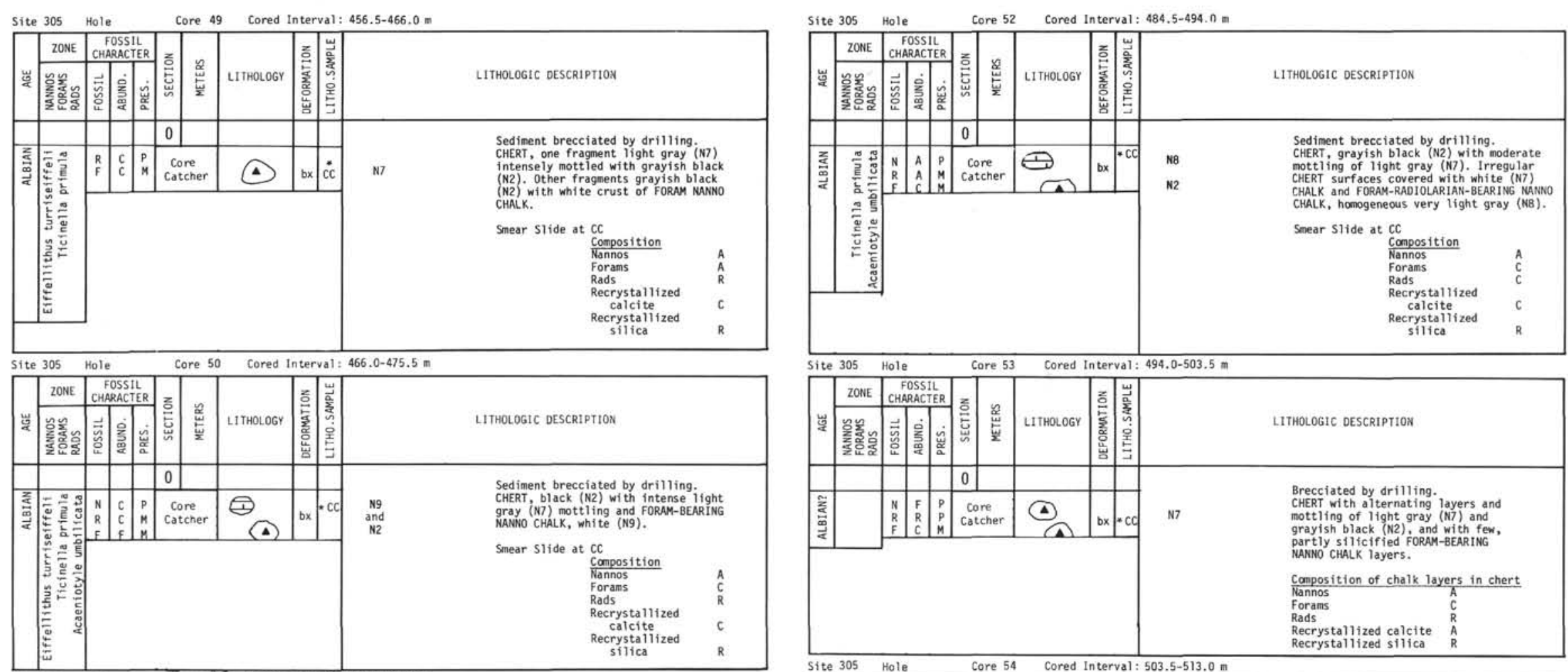

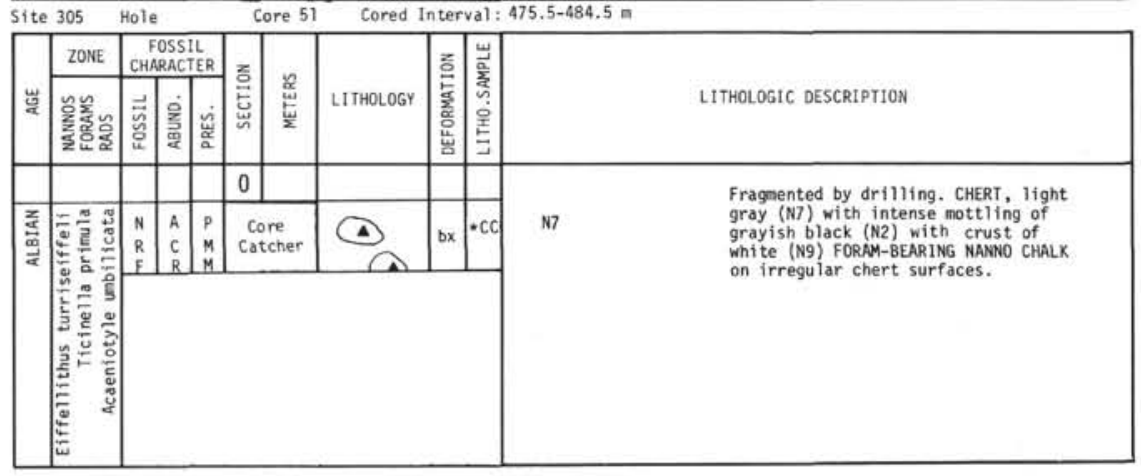

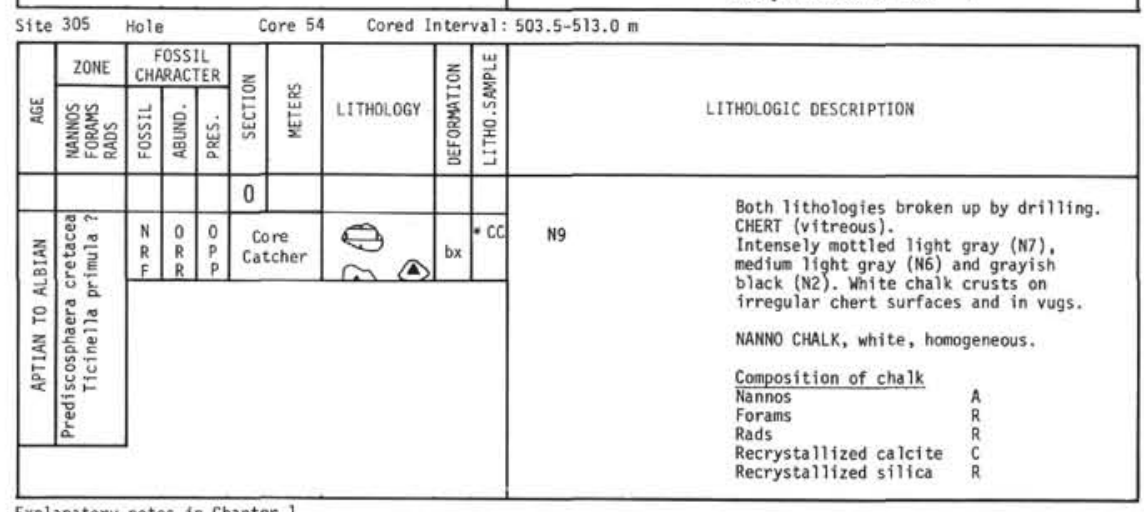




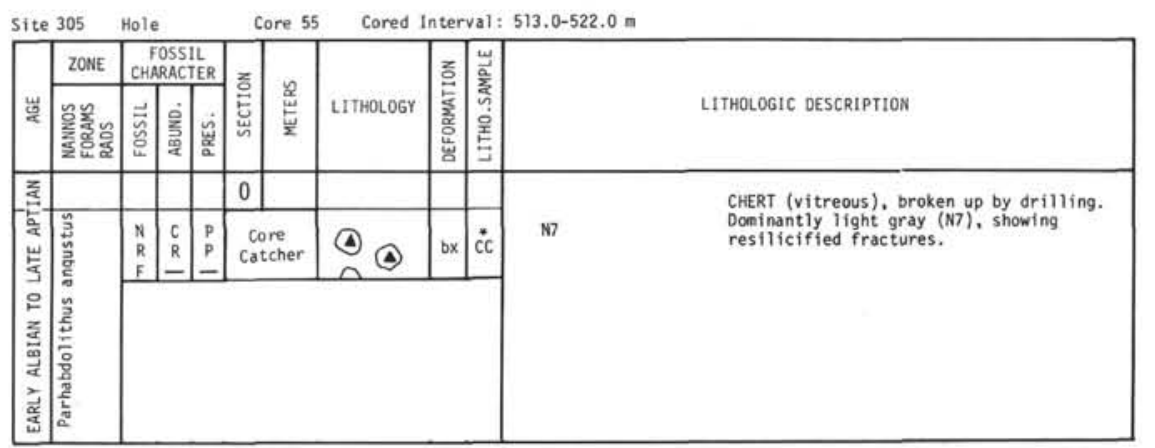

\begin{tabular}{|c|c|c|c|c|c|c|c|c|c|}
\hline Site & 305 & Hole & & & Core $5 t$ & Cored I & nterval: & $11.0-550.5 \mathrm{~m}$ & \\
\hline & \begin{tabular}{|l|l|} 
ZONE \\
\end{tabular} & & $\begin{array}{l}\text { OSSIL } \\
\text { RACTE } \\
\text { RAC }\end{array}$ & & $z$ & & & & \\
\hline 岁 & 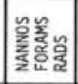 & \begin{tabular}{|c|c|} 
\\
\\
0
\end{tabular} & & & $\frac{\tilde{2}}{\frac{2}{2}}$ & LITHOLOGY & 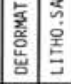 & & ITHOLOGIC DESCRIPTION \\
\hline & & & & & 0 & & & & \\
\hline 伝 & 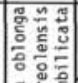 & \begin{tabular}{|l|}
$N$ \\
$R$ \\
$F$ \\
\end{tabular} & & $\begin{array}{c}p \\
\text { pu } \\
p\end{array}$ & $\begin{array}{l}\text { Core } \\
\text { Catcher }\end{array}$ & 4 & $\left.b x\right|^{-c c}$ & $\begin{array}{l}\text { N9 } \\
\text { loYR } 6 / 2\end{array}$ & 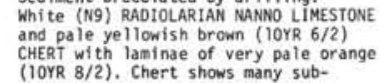 \\
\hline ㅇ & 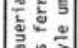 & & & & & & & & $\begin{array}{l}\text { parallelel fractures filled with } \\
\text { chalcedony. }\end{array}$ \\
\hline 高 & 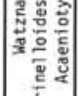 & & & & & & & & $\begin{array}{l}\text { Composition of } 1 \text { imestone } \\
\text { Kanos } \\
\text { Rads } \\
\text { Recrystallized calcite }\end{array}$ \\
\hline 氶 & $\frac{\mathrm{a}}{\circ}$ & & & & & & & & $\frac{\text { Carbon-Carbonate }}{\operatorname{cc}(7.6-0-63)}$ \\
\hline
\end{tabular}

\begin{tabular}{|l|l|l|l|l|l|l|l|l|l|}
\hline Site 305 & Hole \\
\hline
\end{tabular}

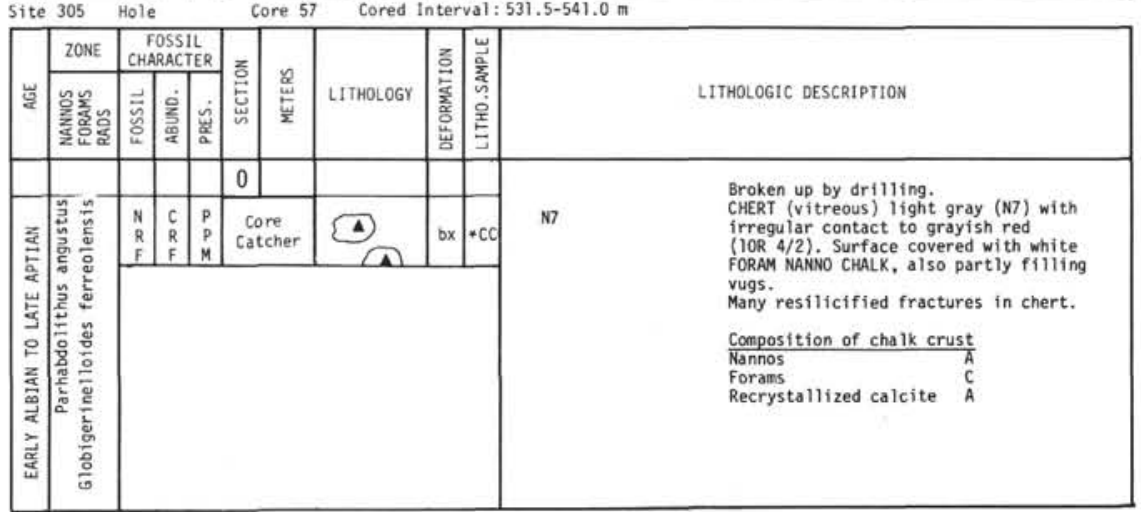

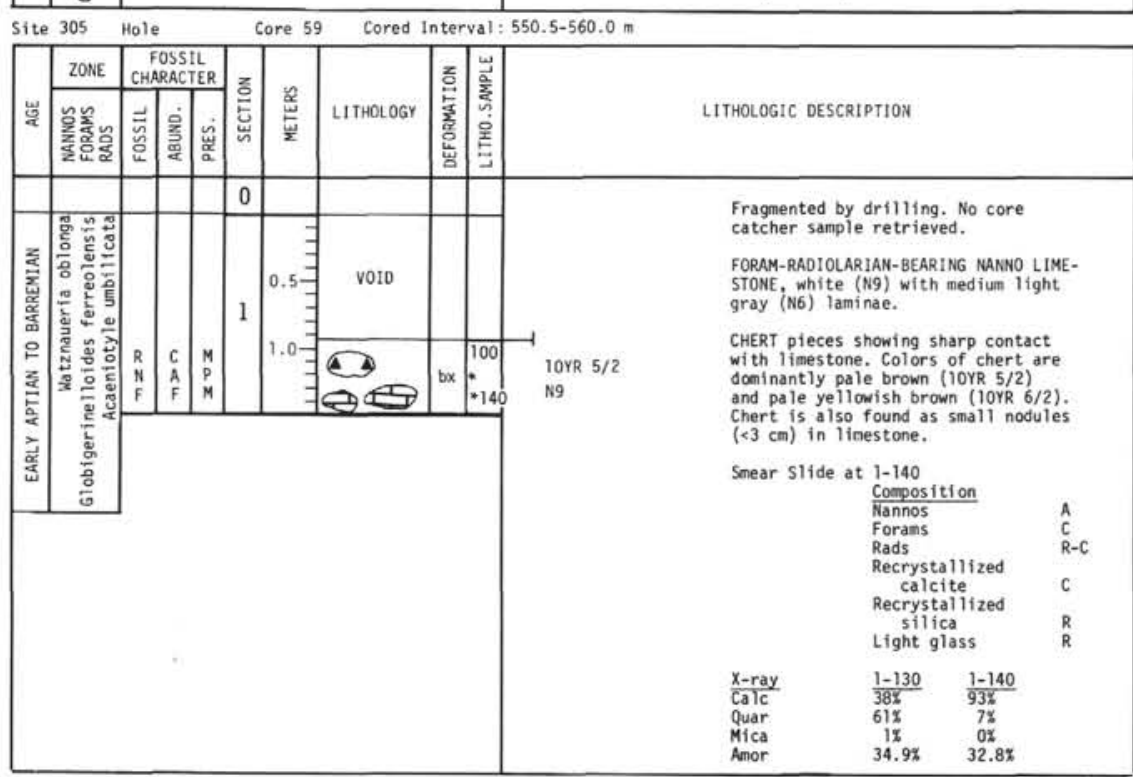

Explanatory notes in Chapter 1 


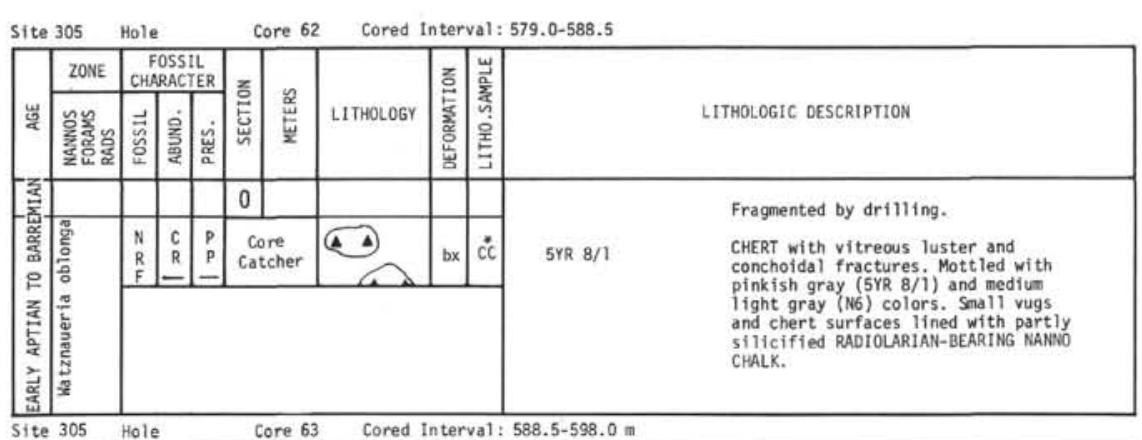

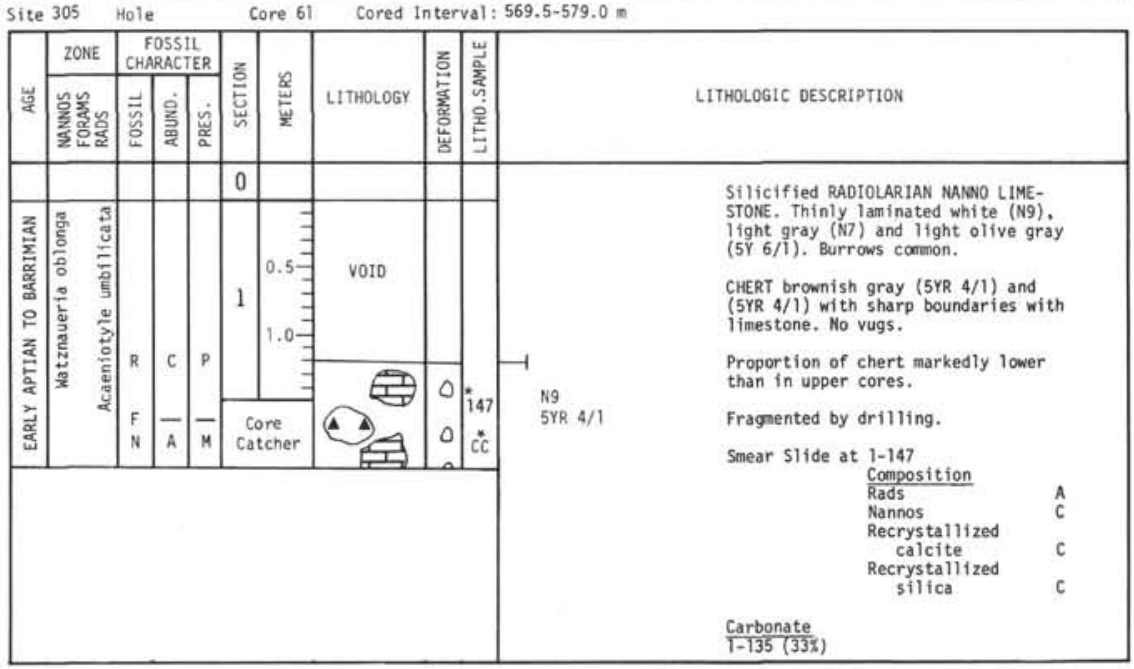

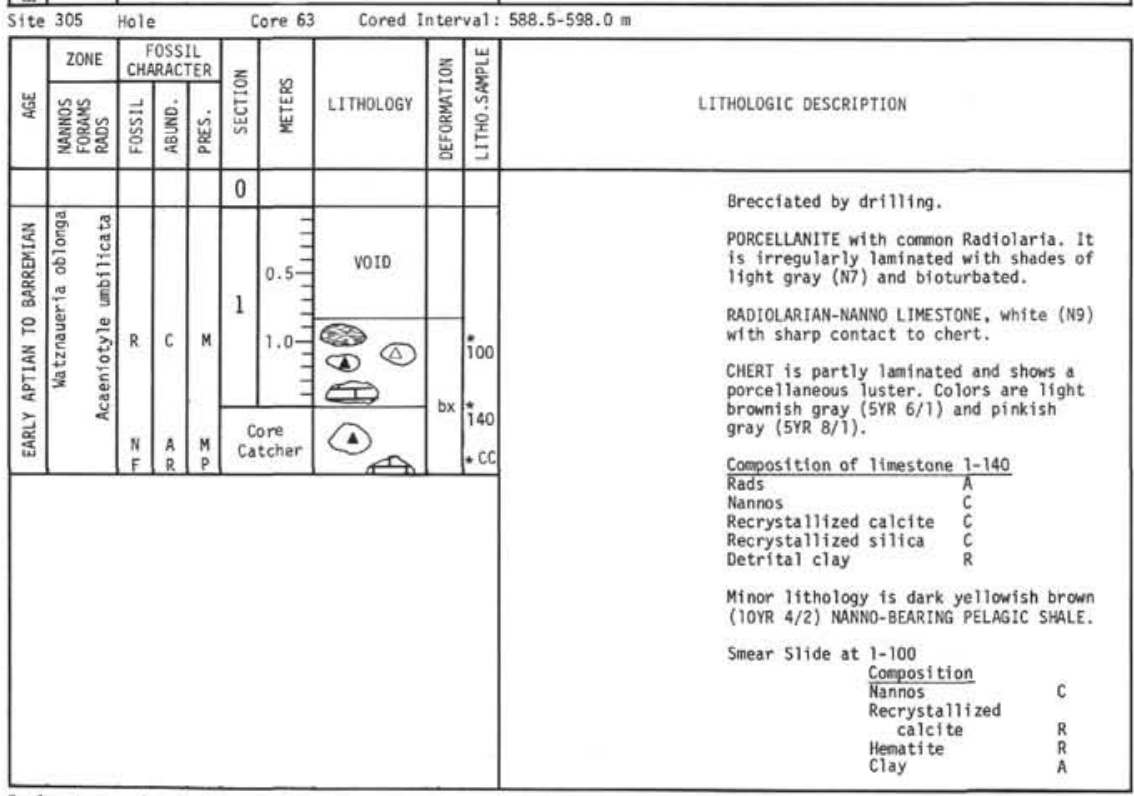



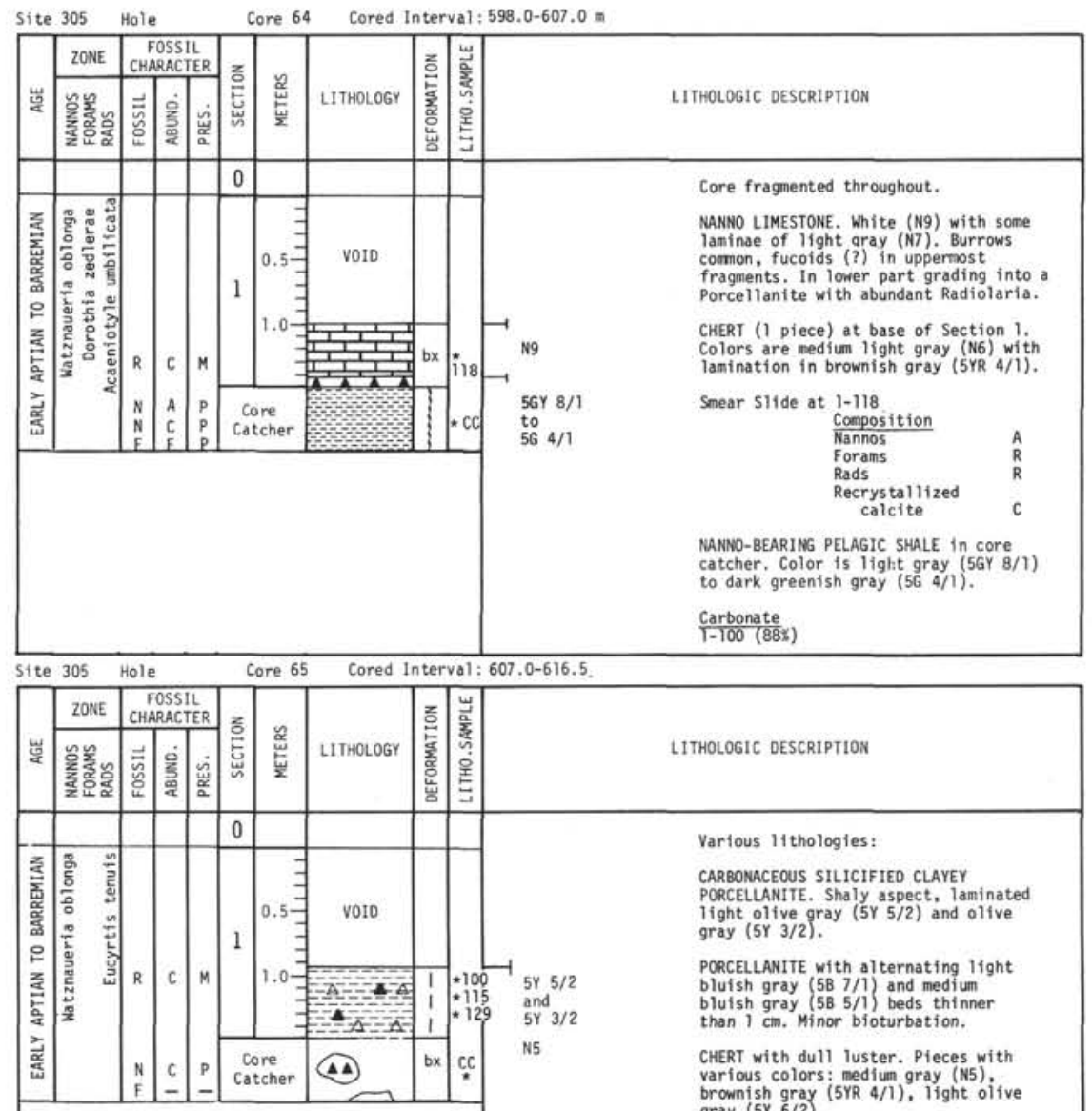

\section{LITHOLOGIC DESCRIPTION}

\section{Various 11thologies:}

CARBONACEOUS SILICIFIED CLAYEY

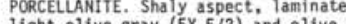
1ight olive gray
gray $(5 Y 3 / 2)$. PORCELLANITE with alternating 1 ight bluish gray $585 / 1$ beds thinner
than $1 \mathrm{~cm}$. Minor bioturbation.

CHERT with dull luster. Pieces with brownish gray (5YR 4/1), light olive gray $(5 Y 6 / 2)$

Smear s1ide at 1-100

$$
\begin{aligned}
& \text { t 1-100 } \\
& \text { Composition } \\
& \text { Kannos } \\
& \text { Rads } \\
& \text { Recrystallized } \\
& \text { silica } \\
& \text { Pyrite } \\
& \text { Anorphous iron } \\
& \text { oxide } \\
& \text { Clay minerals }
\end{aligned}
$$

Smear slide at 1-129$$
\begin{aligned}
& R \\
& R
\end{aligned}
$$

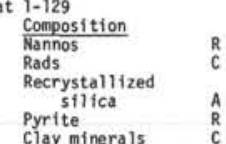

\begin{tabular}{|c|c|c|c|c|c|c|c|c|}
\hline Site & & Hole & & core & red I & nterval: & $5.5-640.5 \mathrm{~m}$ & \\
\hline & ZONE & $\begin{array}{l}\text { F F } \\
\text { CHARA }\end{array}$ & $\begin{array}{l}\text { SIL } \\
\text { ACTER }\end{array}$ & & & ü & & \\
\hline 岁 & 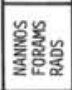 & 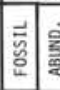 & 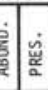 & 站 & LITHOLOGY & 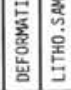 & & ITHOLOGIC DESCRIPTION \\
\hline & & & & 0 & & & & \\
\hline 枟 & 莺 & \begin{tabular}{|l|l}
$N$ & $C$ \\
$R$ & $R$ \\
$F$ &
\end{tabular} & $\stackrel{p}{p}$ & $\begin{array}{c}\text { Core } \\
\text { catcher }\end{array}$ & (44) (4) & cc & N3 with $\mathrm{N} 7$ & $\begin{array}{l}\text { Two pieces, dark gray (N3) mott led with } \\
\text { shades of ifght gray (NN). Few vugs } \\
\text { contain white nanno chalk. }\end{array}$ \\
\hline 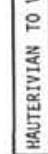 & 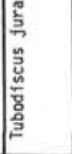 & & & & & & & \\
\hline
\end{tabular}

$\frac{\text { Carbon-Carbonate }}{-100(10.4-9.3-9)}$

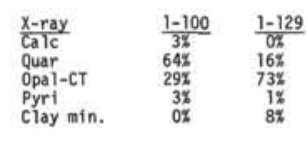

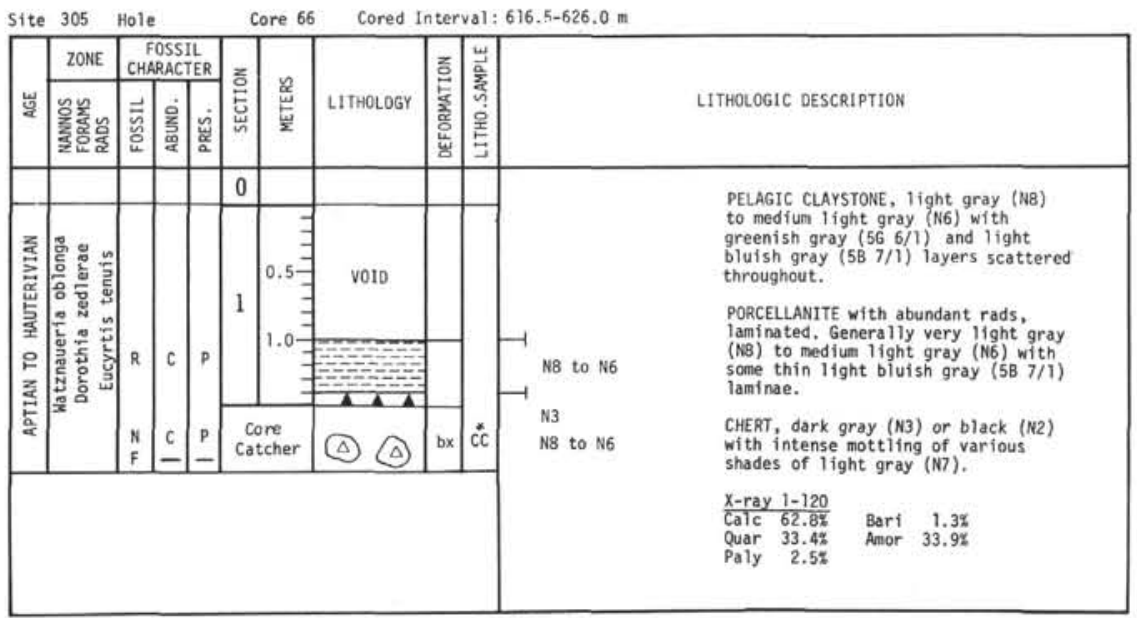

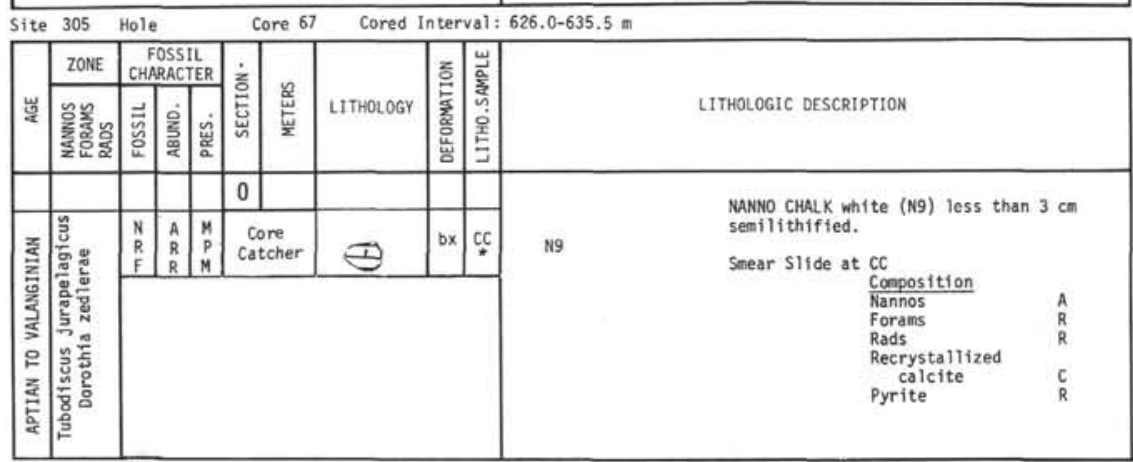

Explanatory notes in Chapter 
CORE 305-1

- $=$ GRAPE WET-BULK DENSITY, g/cC

- Syringe porosity, \% COMPRESSIONAL SOUND VELOCITY

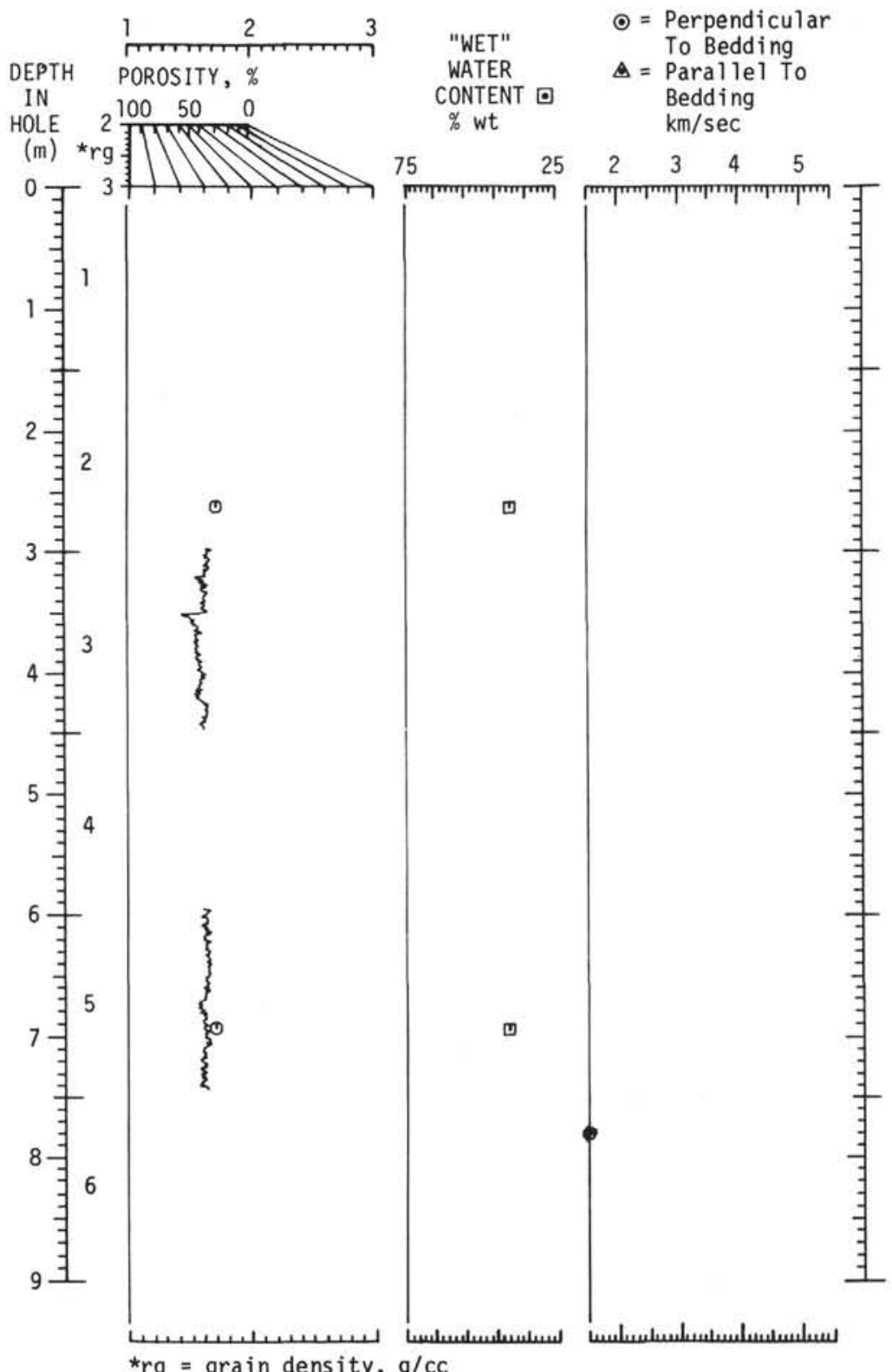

CORE 305-2

- = GRAPE WET-BULK DENSITY, g/cc

- Syringe porosity, \% COMPRESSIONAL SOUND VELOCITY

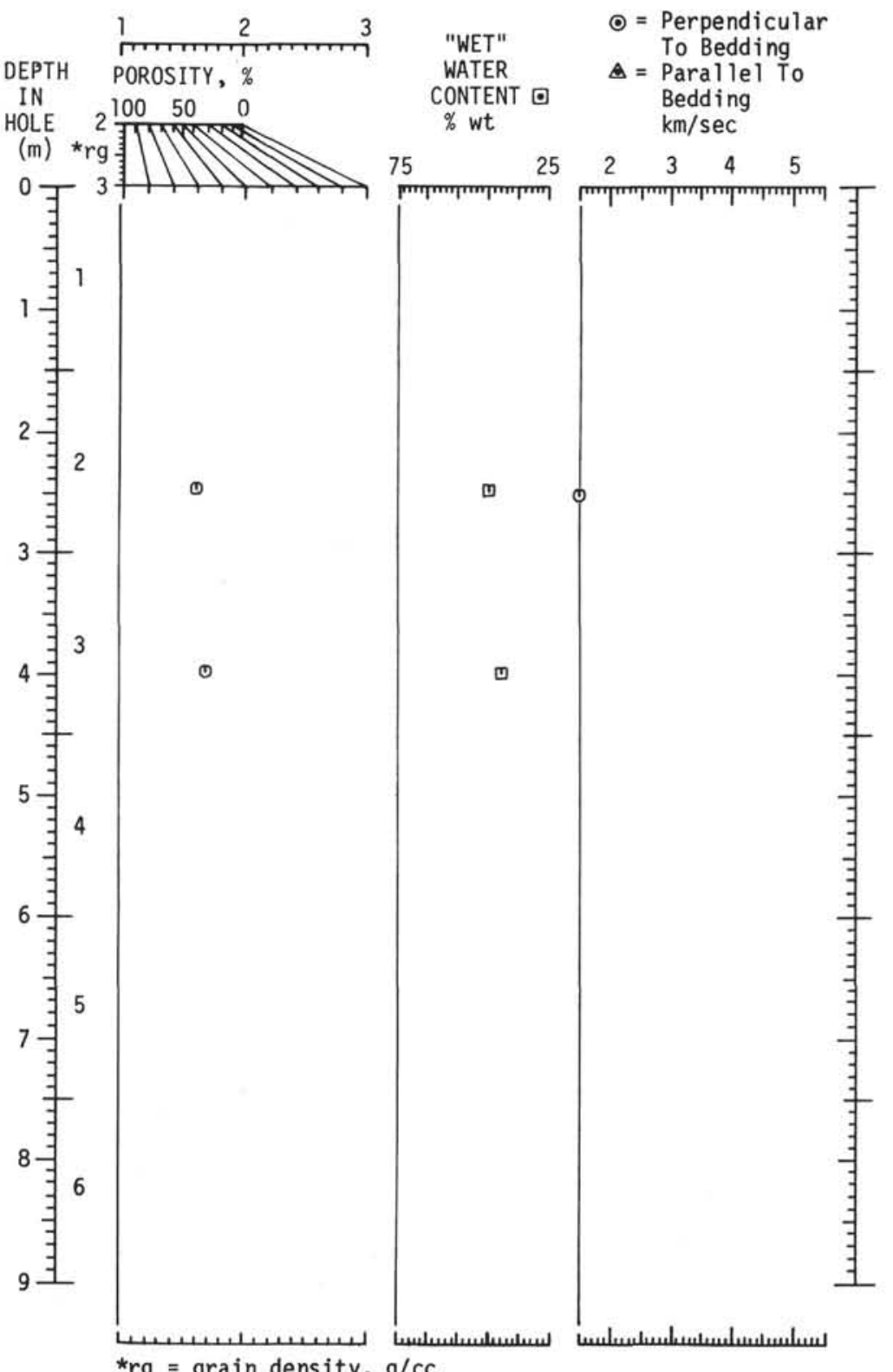


CORE $305-3$

- = GRAPE WET-BULK DENSITY, $g / c c$

○ Syringe porosity, \% COMPRESSIONAL SOUND VELOCITY

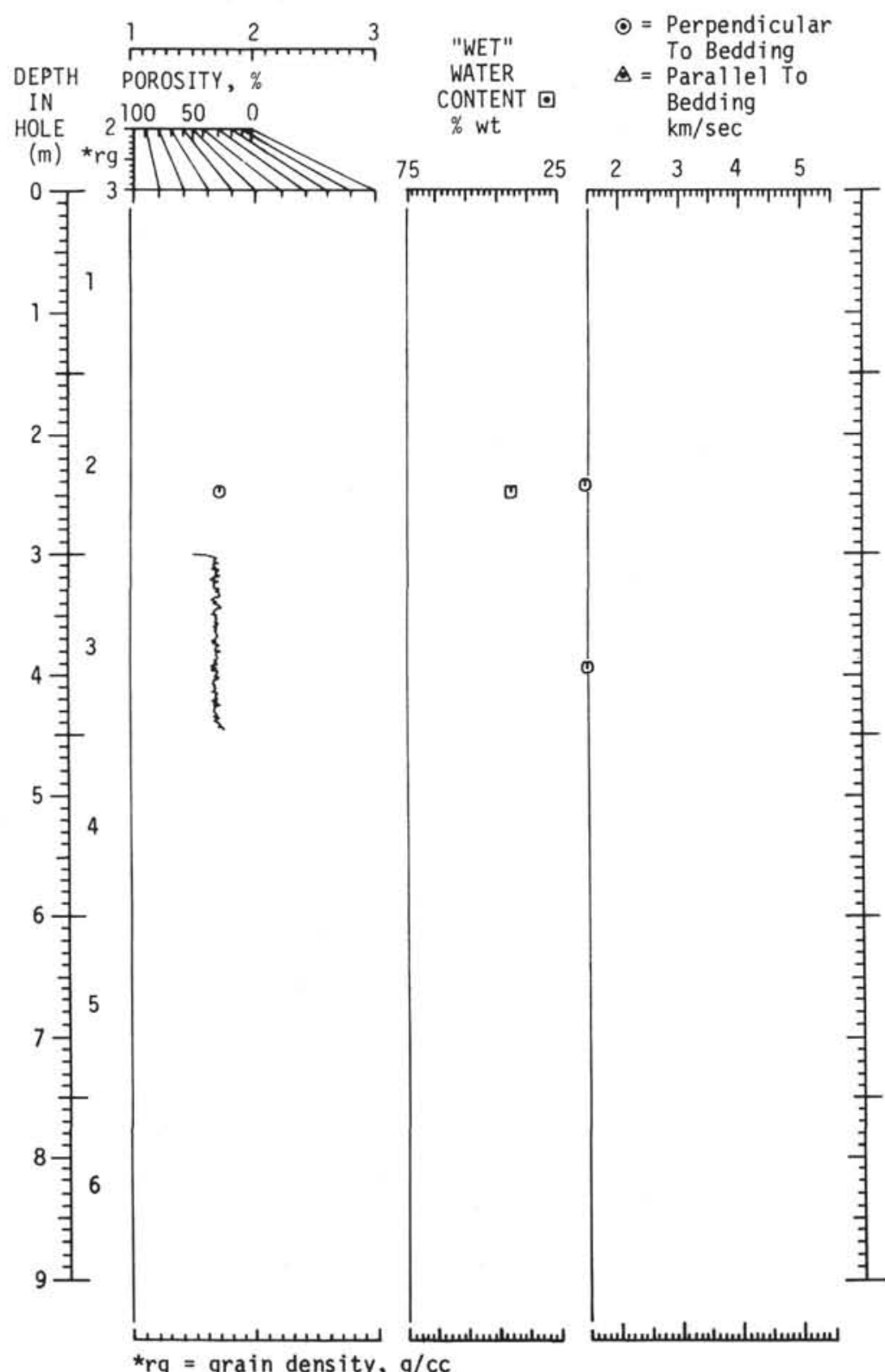

CORE $305-4$

$=$ GRAPE WET-BULK DENSITY, g/cc

- Syringe porosity, \% COMPRESSIONAL SOUND VELOCITY

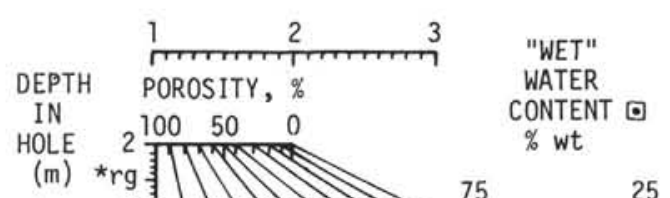

$\odot=$ Perpendicular To Bedding

$\Delta=$ Parallel To

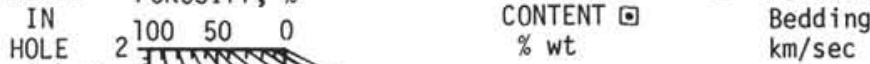

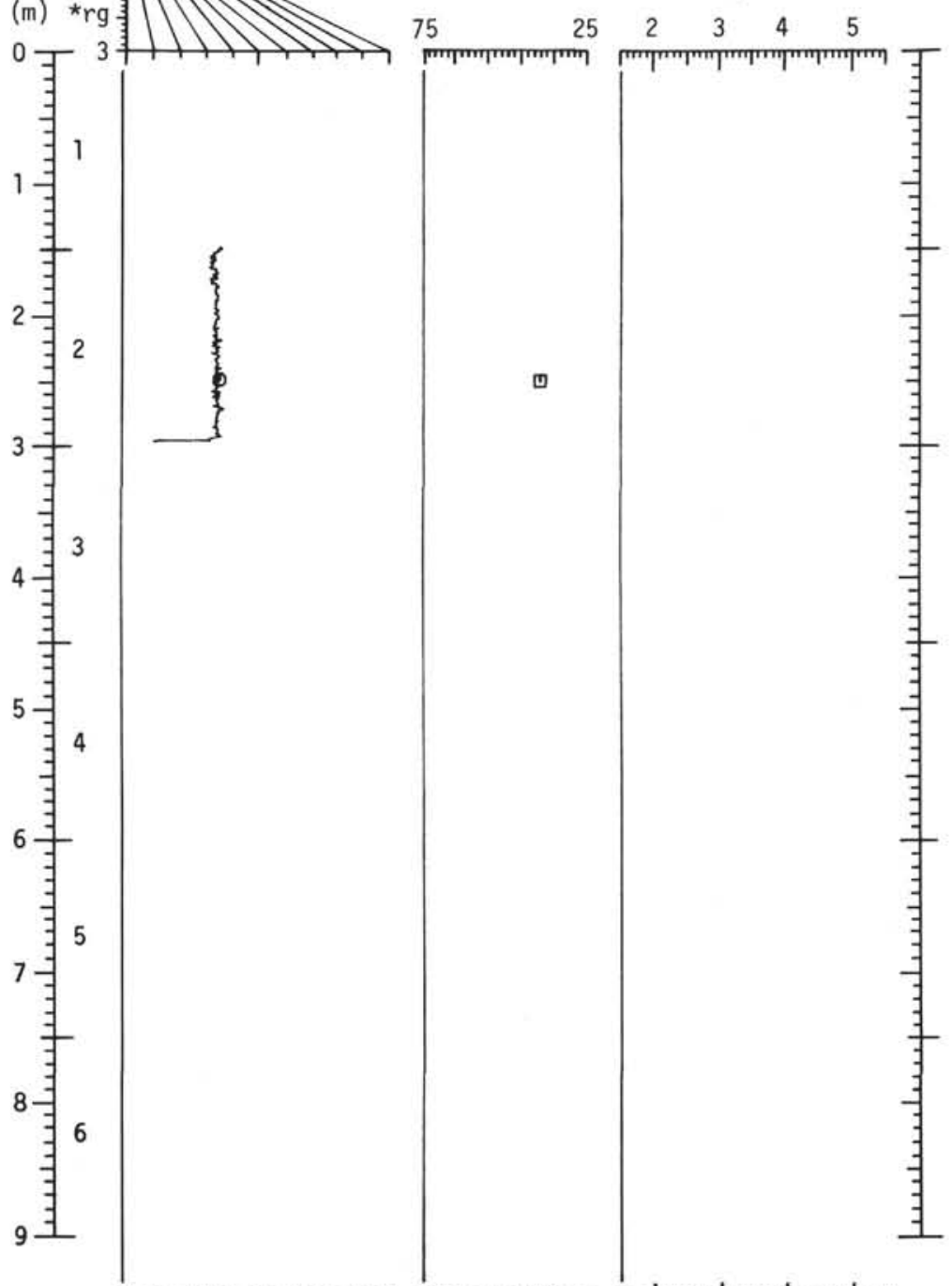

*rg = grain density, g/cc 
- Syringe porosity, \% COMPRESSIONAL SOUND VELOCITY

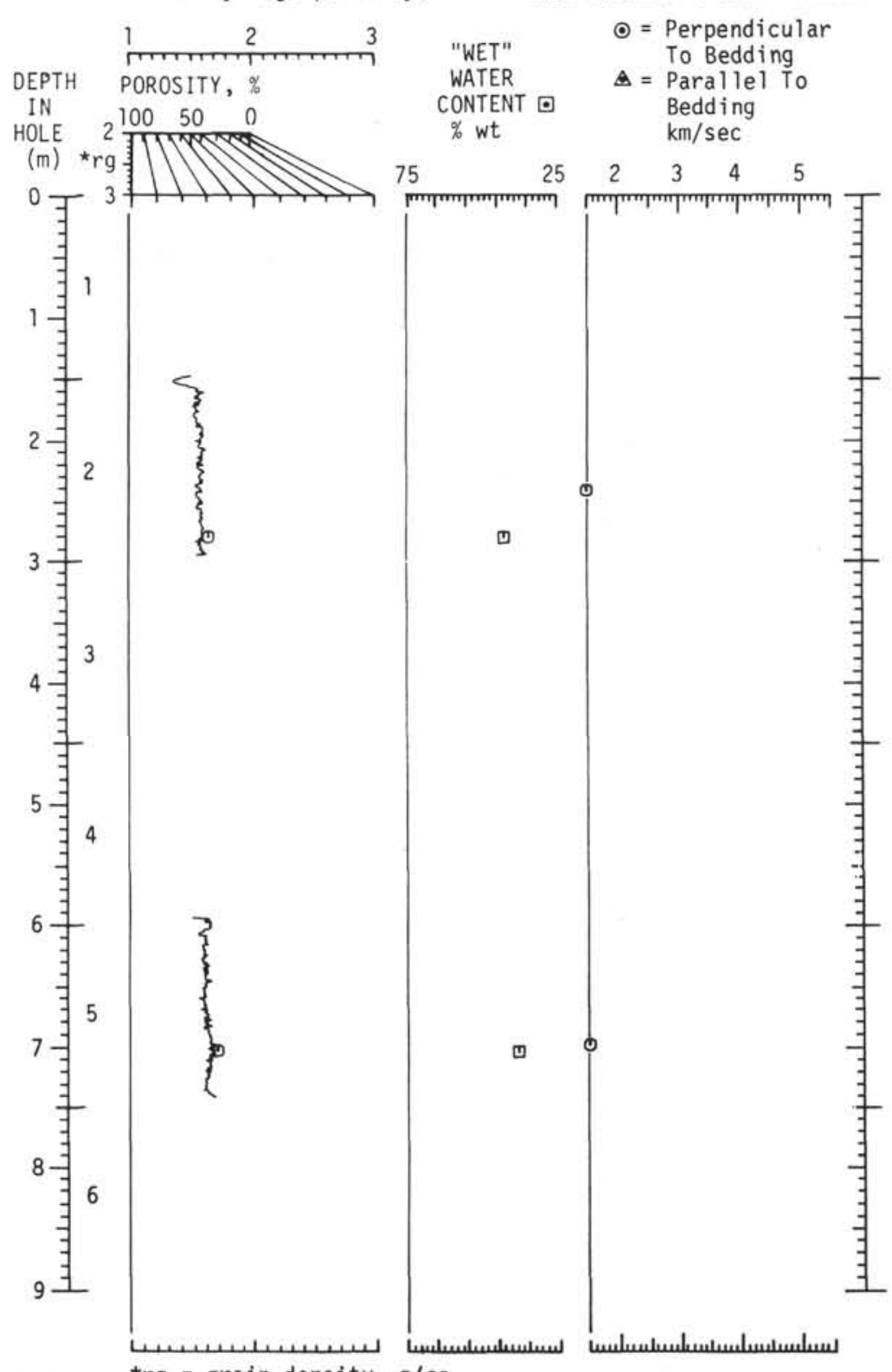

- = GRAPE WET-BULK DENSITY, g/cC

○ Syringe porosity, $\%$ COMPRESSIONAL SOUND VELOCITY

\begin{tabular}{|c|c|c|c|c|}
\hline & & $2 \quad 3$ & "WET" & $\odot=$ Perpendicular \\
\hline DEPTH & POROSITY, & $\%$ & WATER & $\Delta=$ Parallel To \\
\hline $\begin{array}{l}\text { IN } \\
\text { HOLE }\end{array}$ & 210050 & 0 & $\begin{array}{l}\text { CONTENT } \square \\
\% \text { wt }\end{array}$ & $\begin{array}{l}\text { Bedding } \\
\mathrm{km} / \mathrm{sec}\end{array}$ \\
\hline
\end{tabular}

wt $\mathrm{km} / \mathrm{sec}$

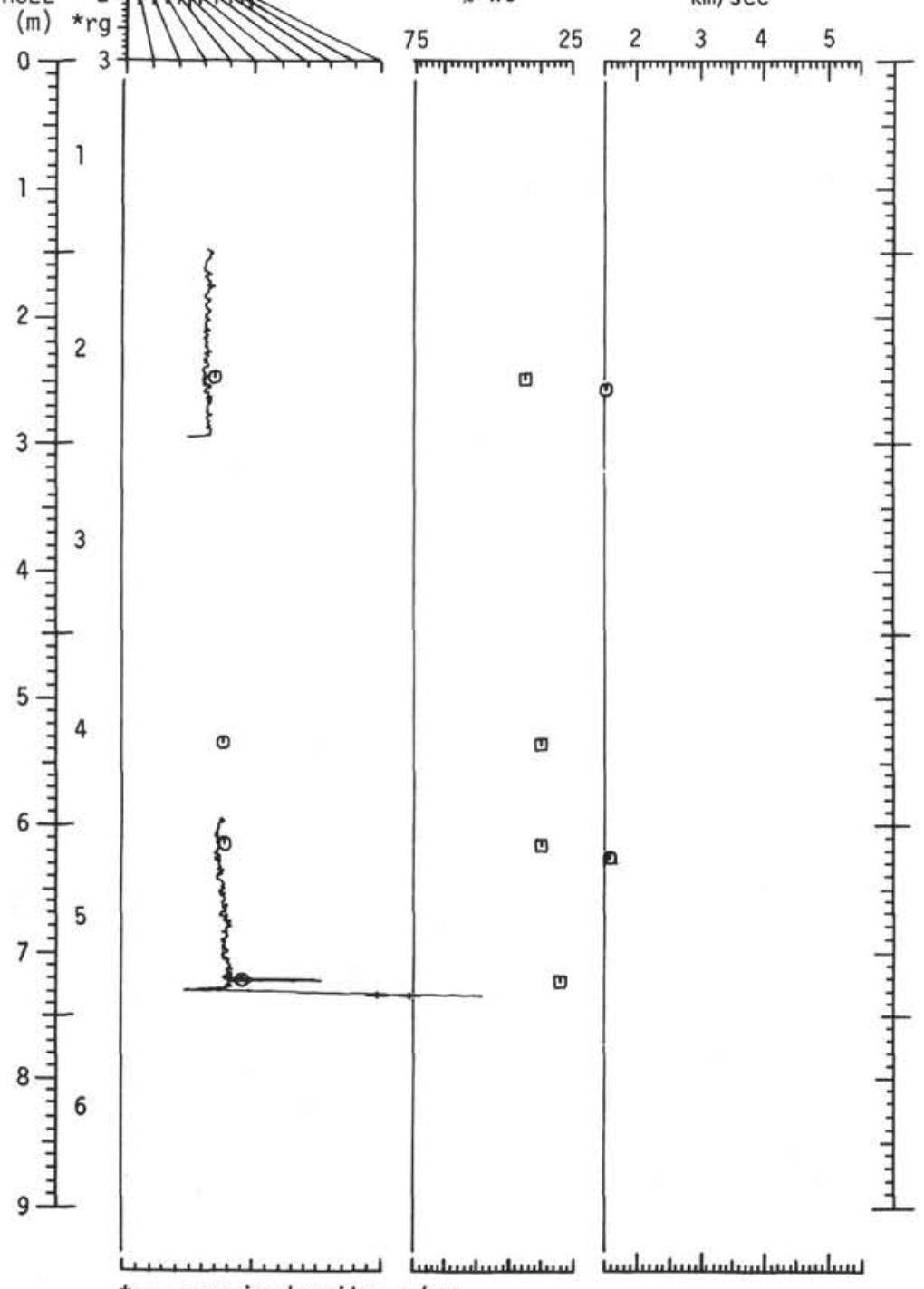


CORE 305-7

- = GRAPE WET-BULK DENSITY, g/cC

- Syringe porosity, \% COMPRESSIONAL SOUND VELOCITY

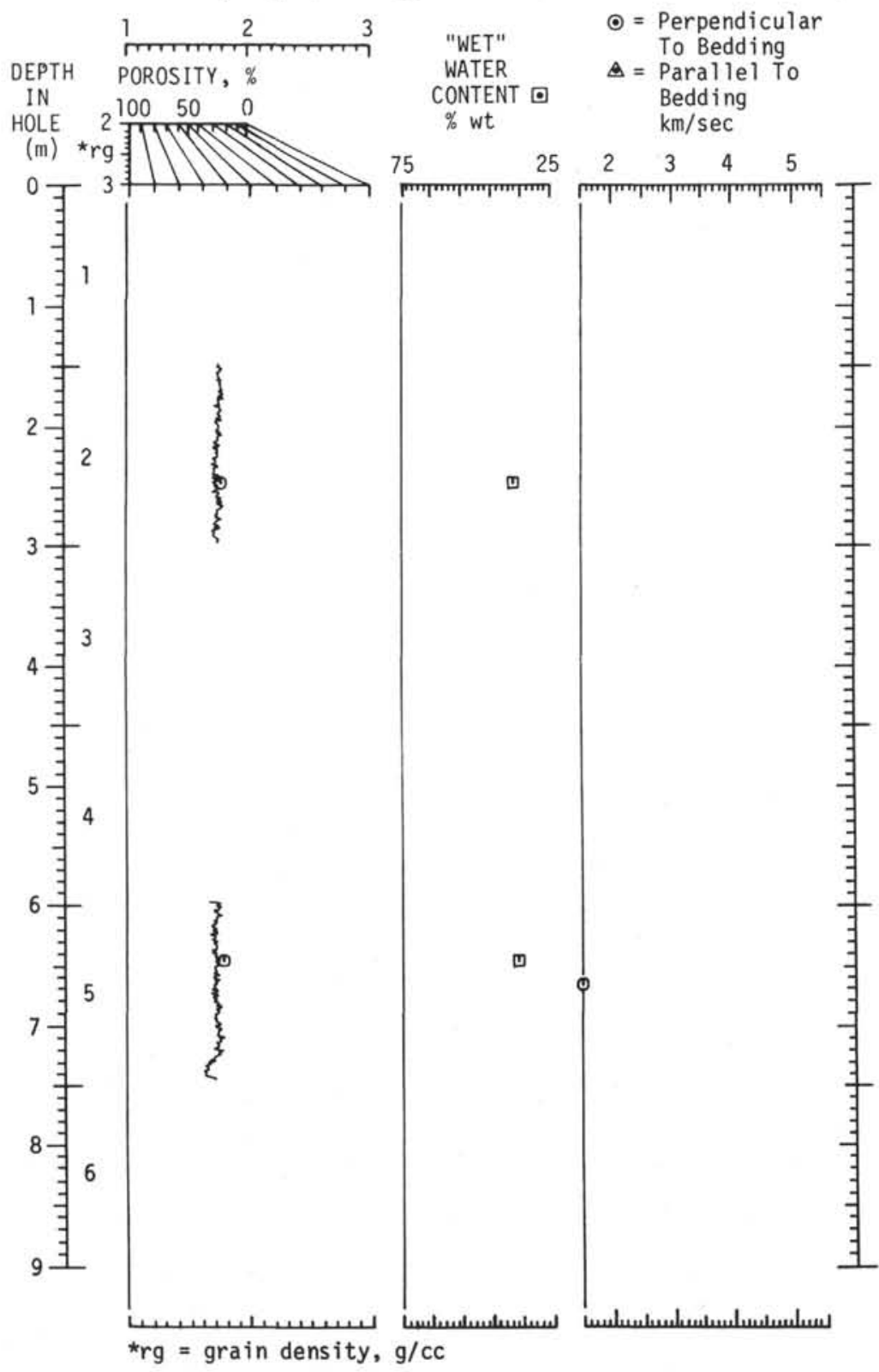

CORE 305-8

- = GRAPE WET-BULK DENSITY, g/cC

- Syringe porosity,

COMPRESSIONAL SOUND VELOCITY

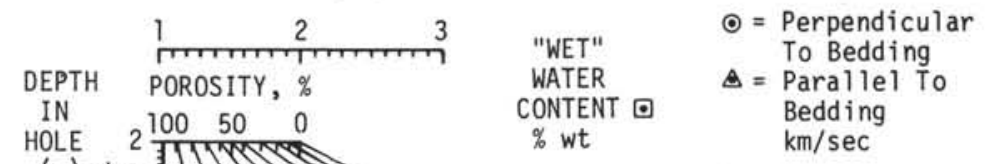

(m) * 2 茟

wt $\mathrm{km} / \mathrm{sec}$

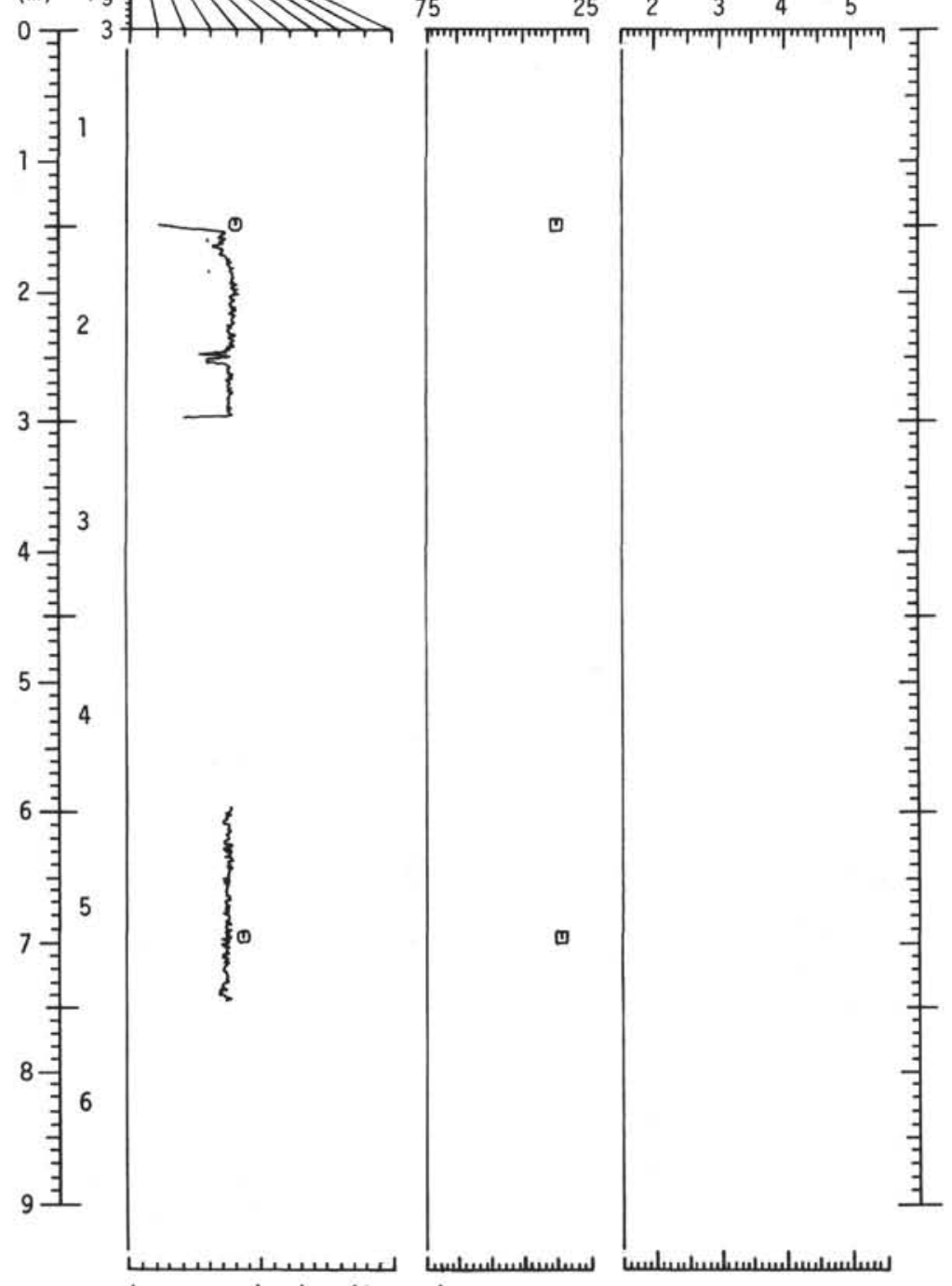

$\star^{*} g=$ grain density, $g / c c$ 
- Syringe porosity, \% COMPRESSIONAL SOUND VELOCITY

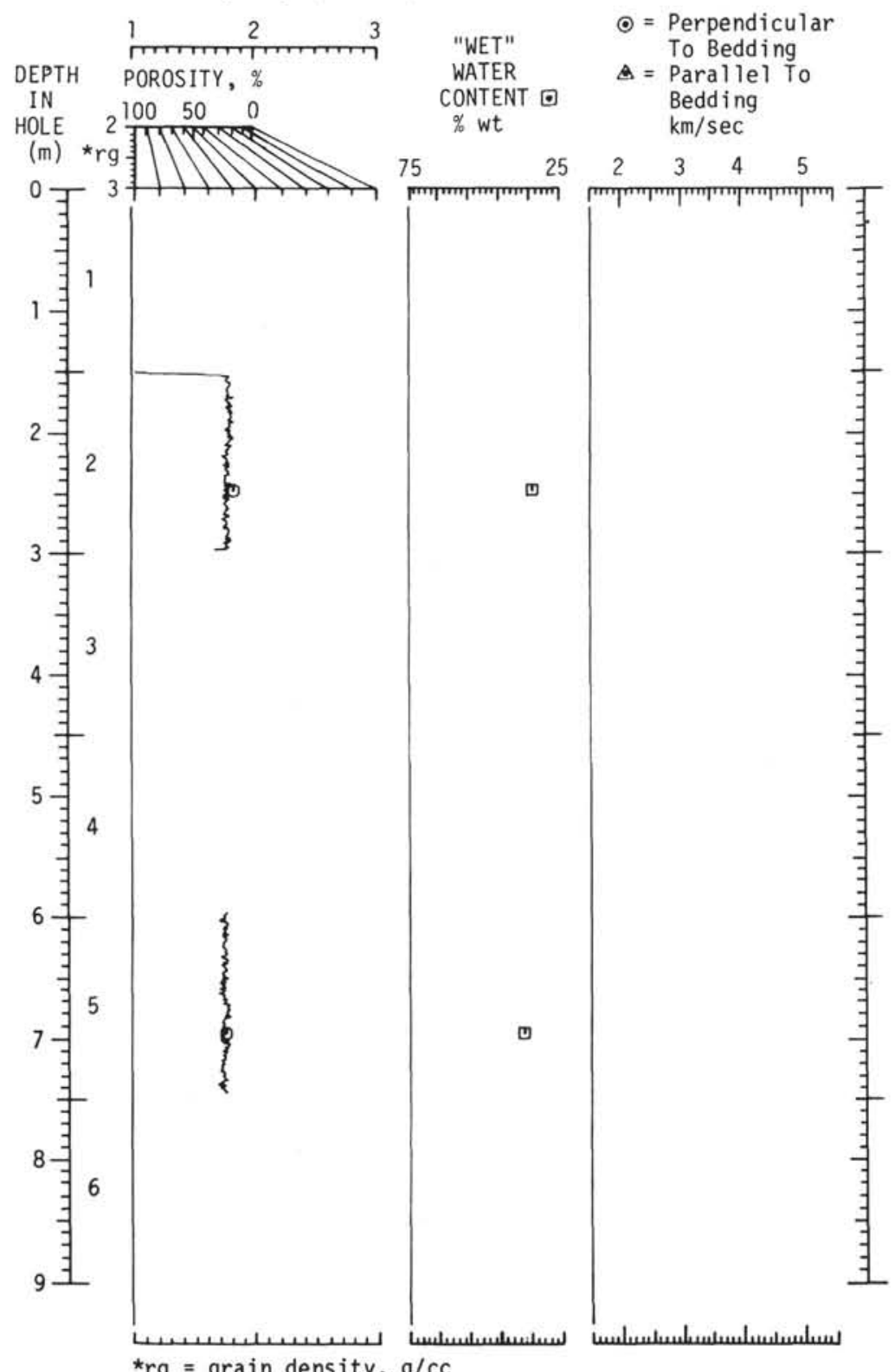

- = GRAPE WET-BULK DENSITY, g/CC.

- Syringe porosity, \% COMPRESSIONAL SOUND VELOCITY

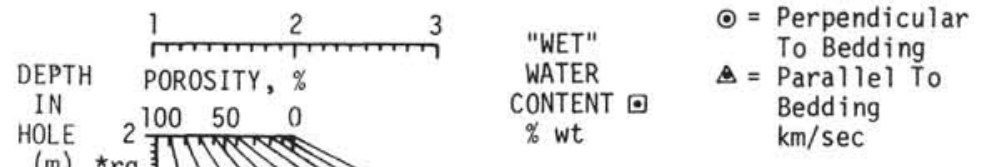

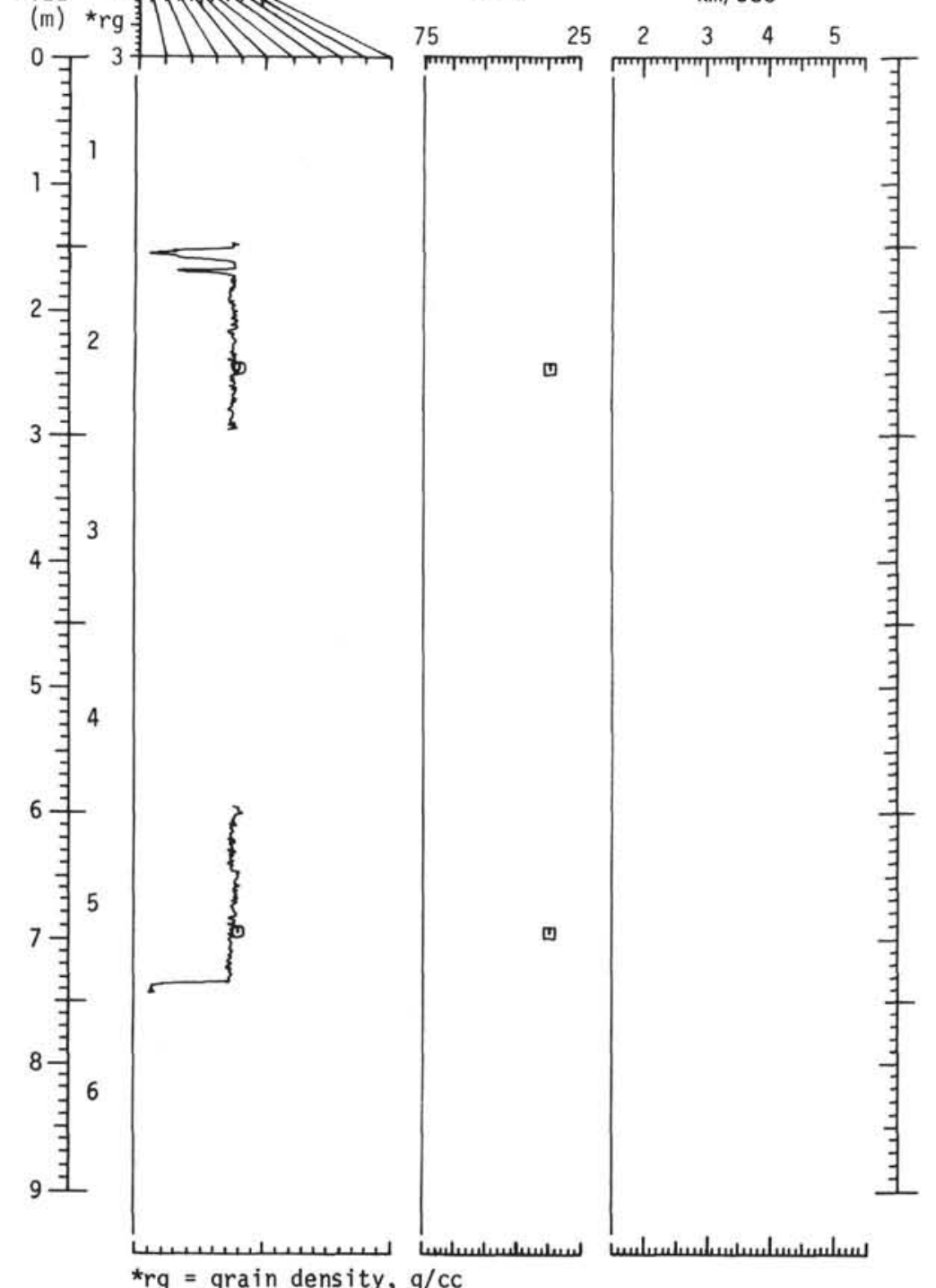


CORE 305-11

- = GRAPE WET-BULK DENSITY, g/cc

- Syringe porosity, \% COMPRESSIONAL SOUND VELOCITY

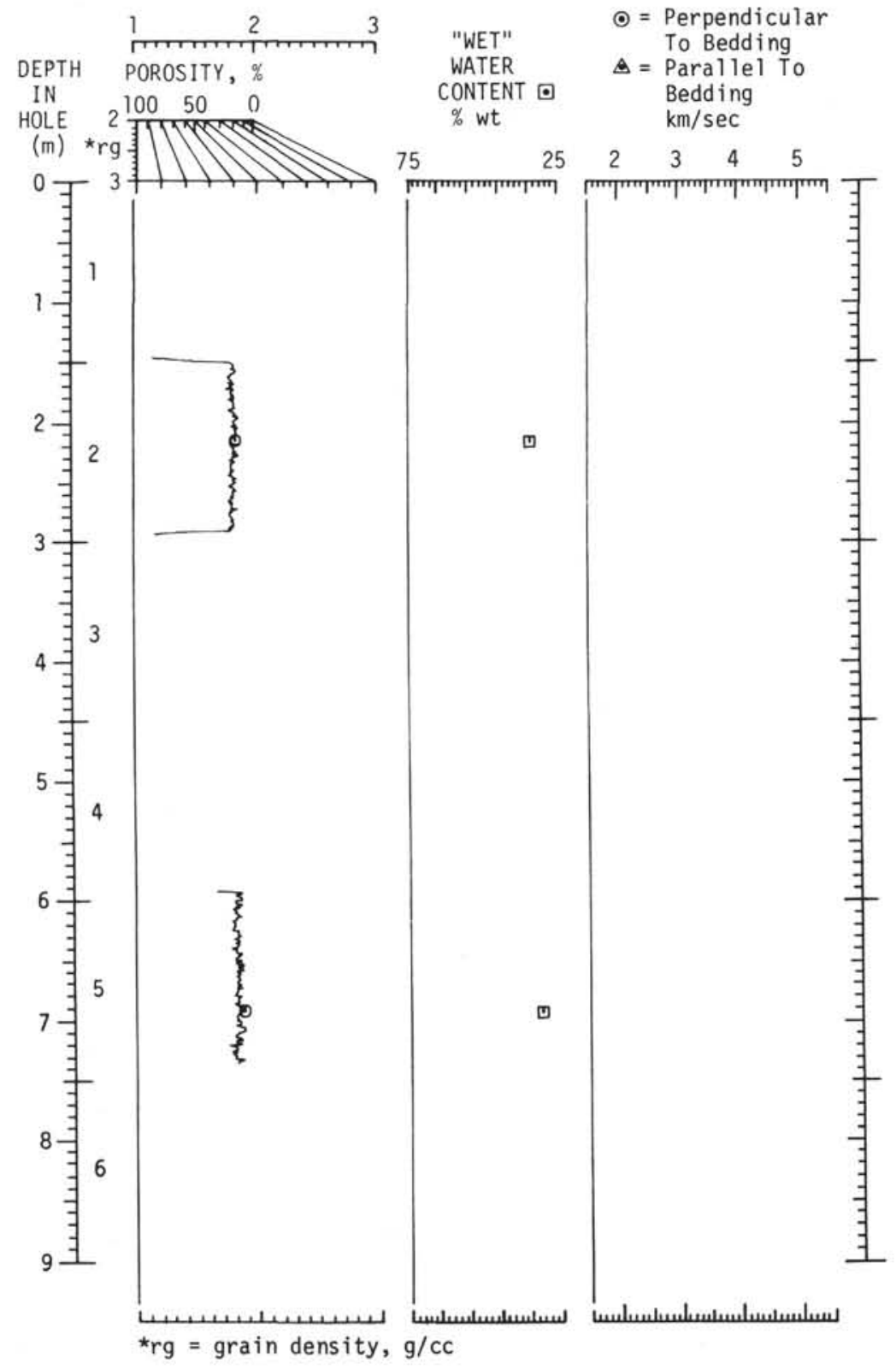

CORE $305-12$

- $=$ GRAPE WET-BULK DENSITY, $\mathrm{g} / \mathrm{cC}$

○ Syringe porosity, \%

COMPRESSIONAL SOUND VELOCITY

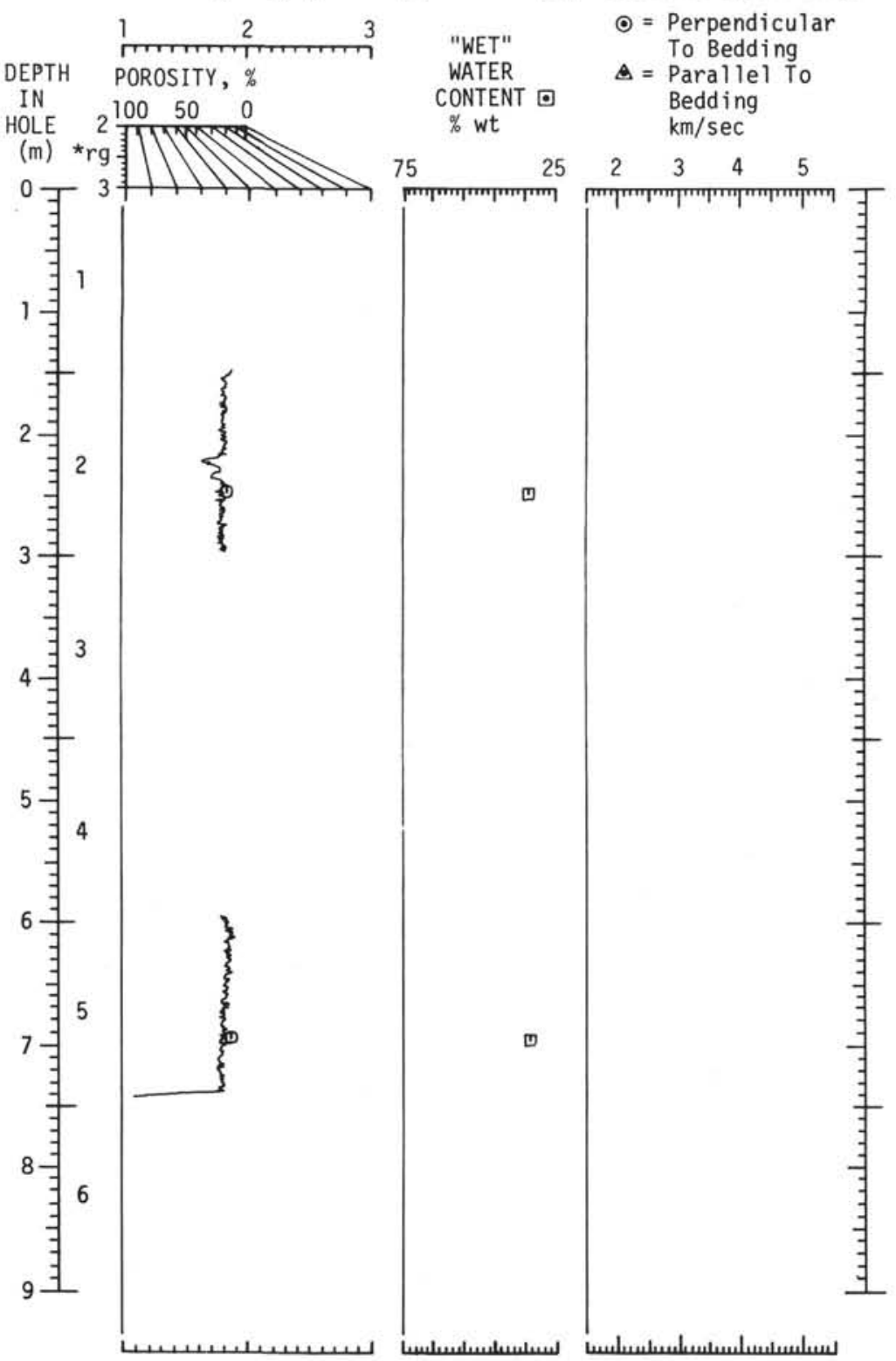

${ }^{*} r g=$ grain density, $g / c c$ 
○ Syringe porosity, \% COMPRESSIONAL SOUND VELOCITY

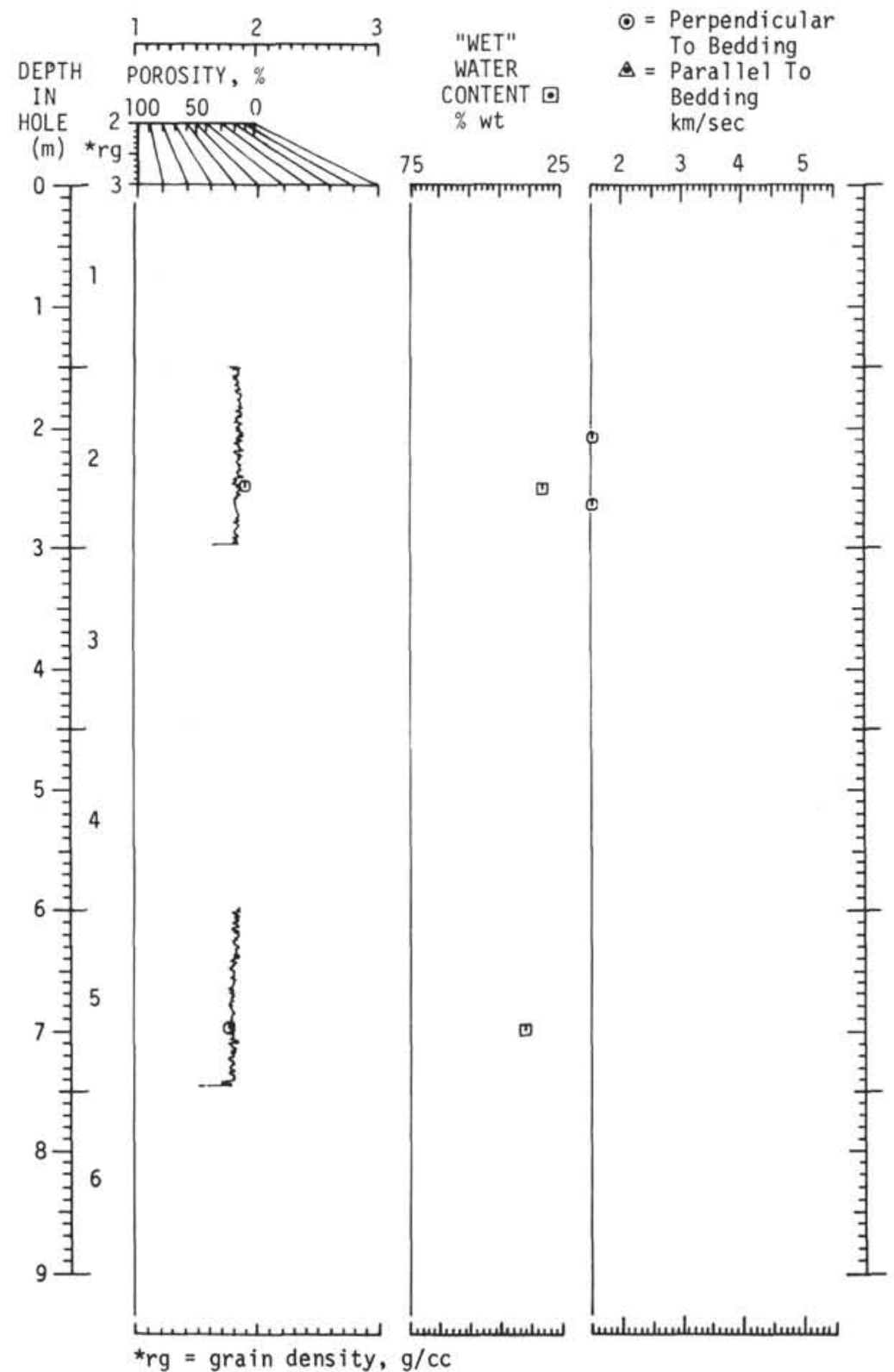

- $=$ GRAPE WET - BULK DENSITY, $g / c c$

๑ Syringe porosity, \% COMPRESSIONAL SOUND VELOCITY $\odot=$ Perpendicular To Bedding

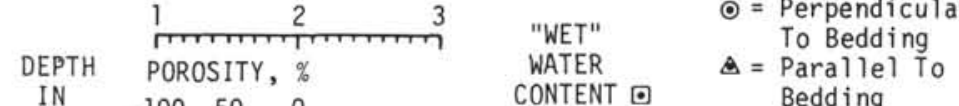
IN $\quad \begin{array}{lllll}100 & 50 & 0 & \text { CONTENT } & 0\end{array}$

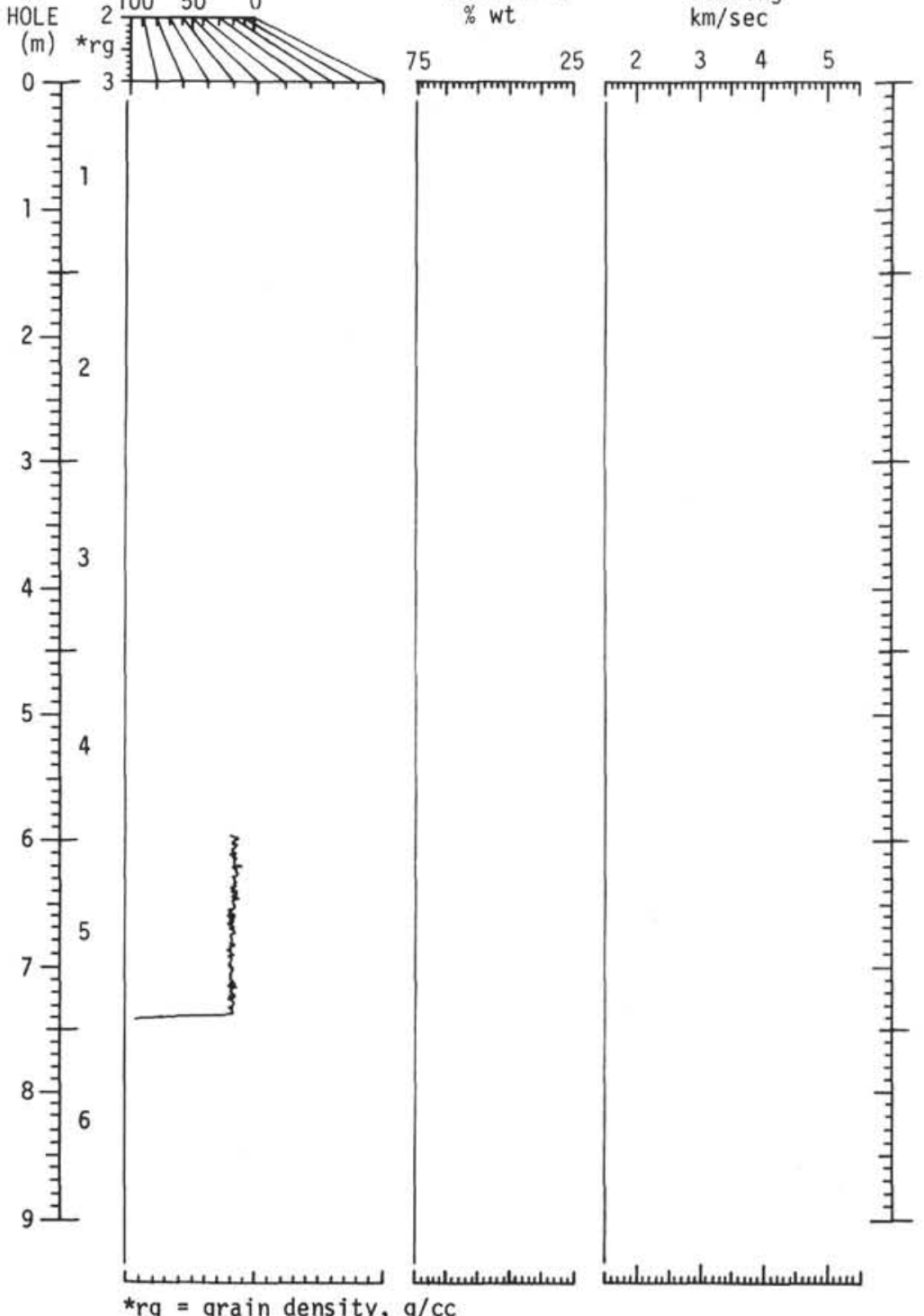




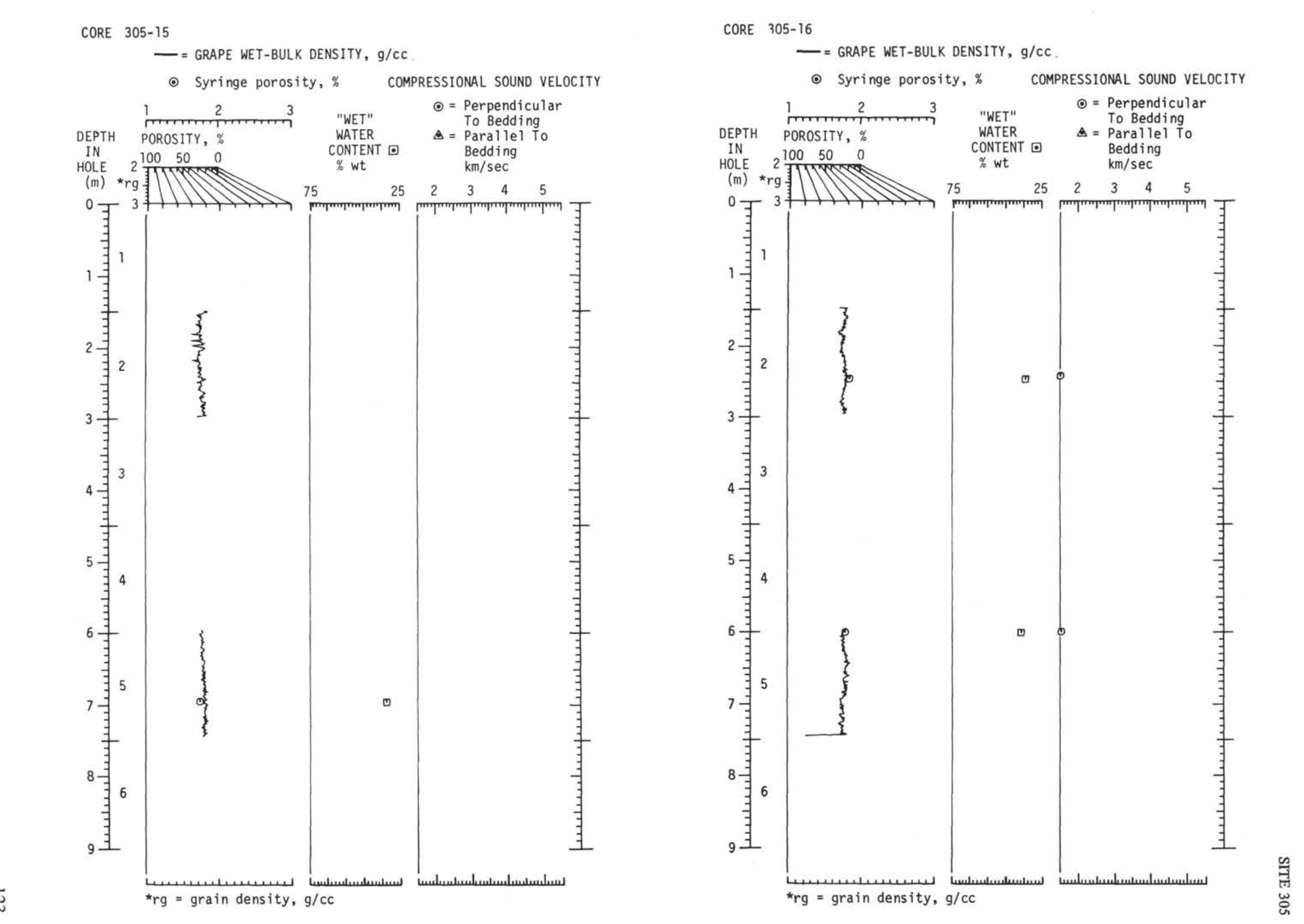


- Syringe porosity, \% COMPRESSIONAL SOUND VELOCITY

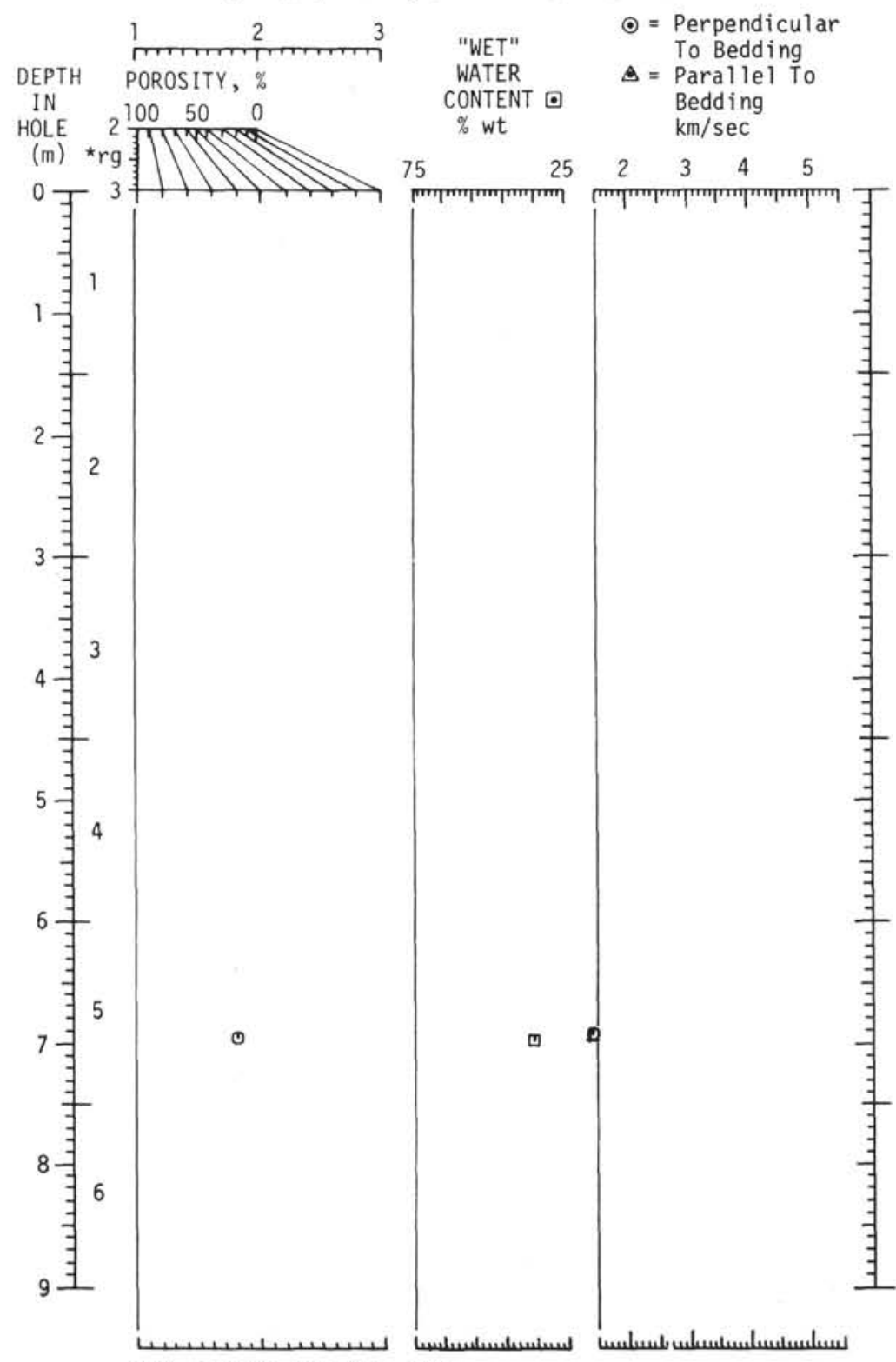

$*_{r g}=$ grain density, $g / c c$
- $=$ GRAPE WET-BULK DENSITY, $g / c C$

- Syringe porosity, \% COMPRESSIONAL SOUND VELOCITY

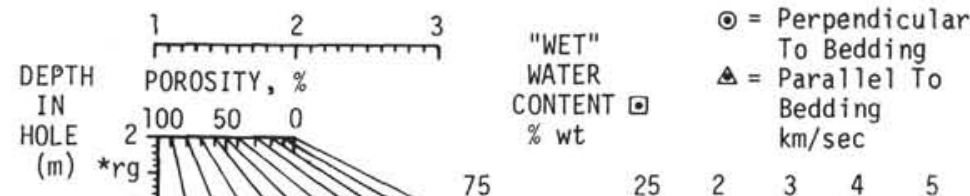

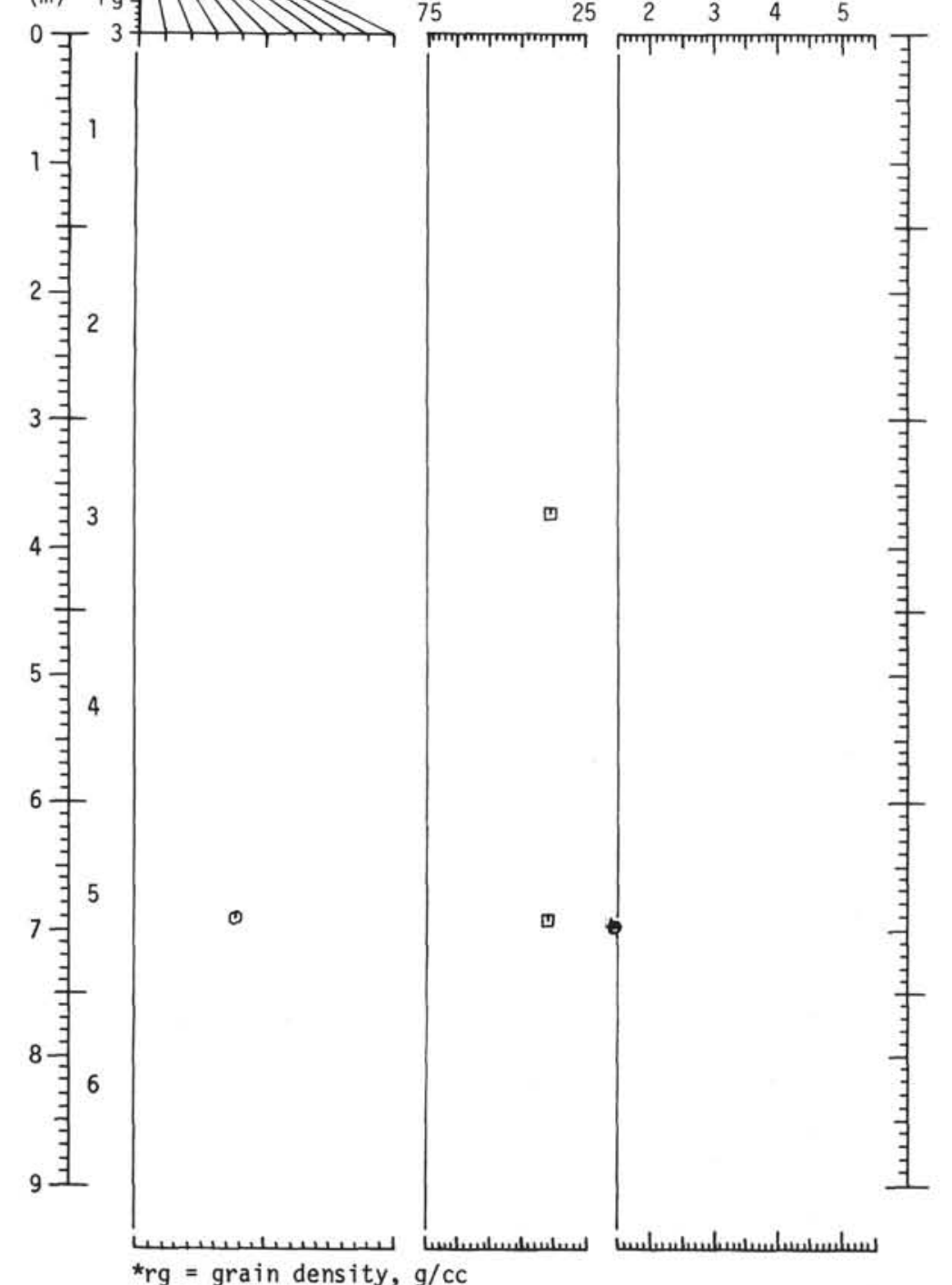


CORE 305-19.

- = GRAPE WET-BULK DENSITY, g/cC

- Syringe porosity, \%

COMPRESSIONAL SOUND VELOCITY

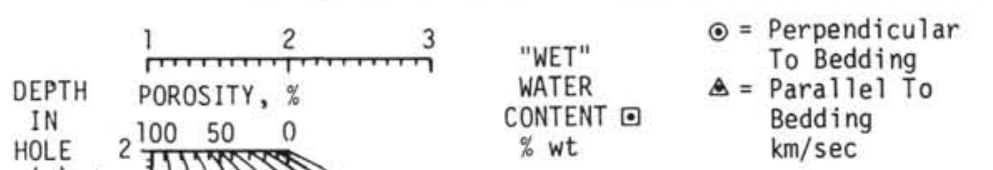

HOLE $21005000 \%$ wt $\quad \mathrm{km} / \mathrm{sec}^{2}$

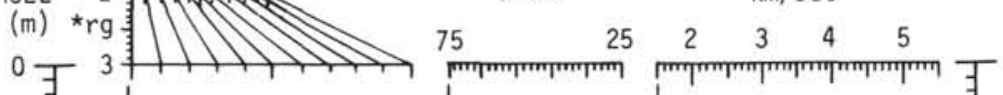

0 更 3 年

当

1 手

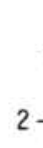

将

3

3.

4 当

青

. 4

$6 \frac{\text { 寻 }}{3}$

青 5

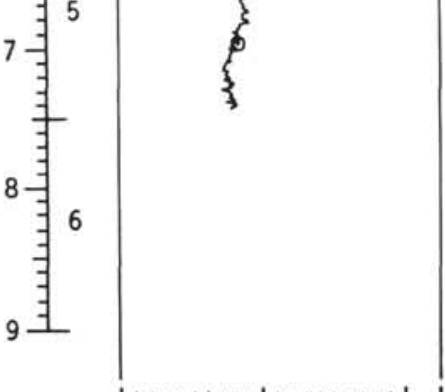

CORE 305-20

$-=$ GRAPE WET-BULK DENSITY, $\mathrm{g} / \mathrm{cc}$

- Syringe porosity, \% COMPRESSIONAL SOUND VELOCITY

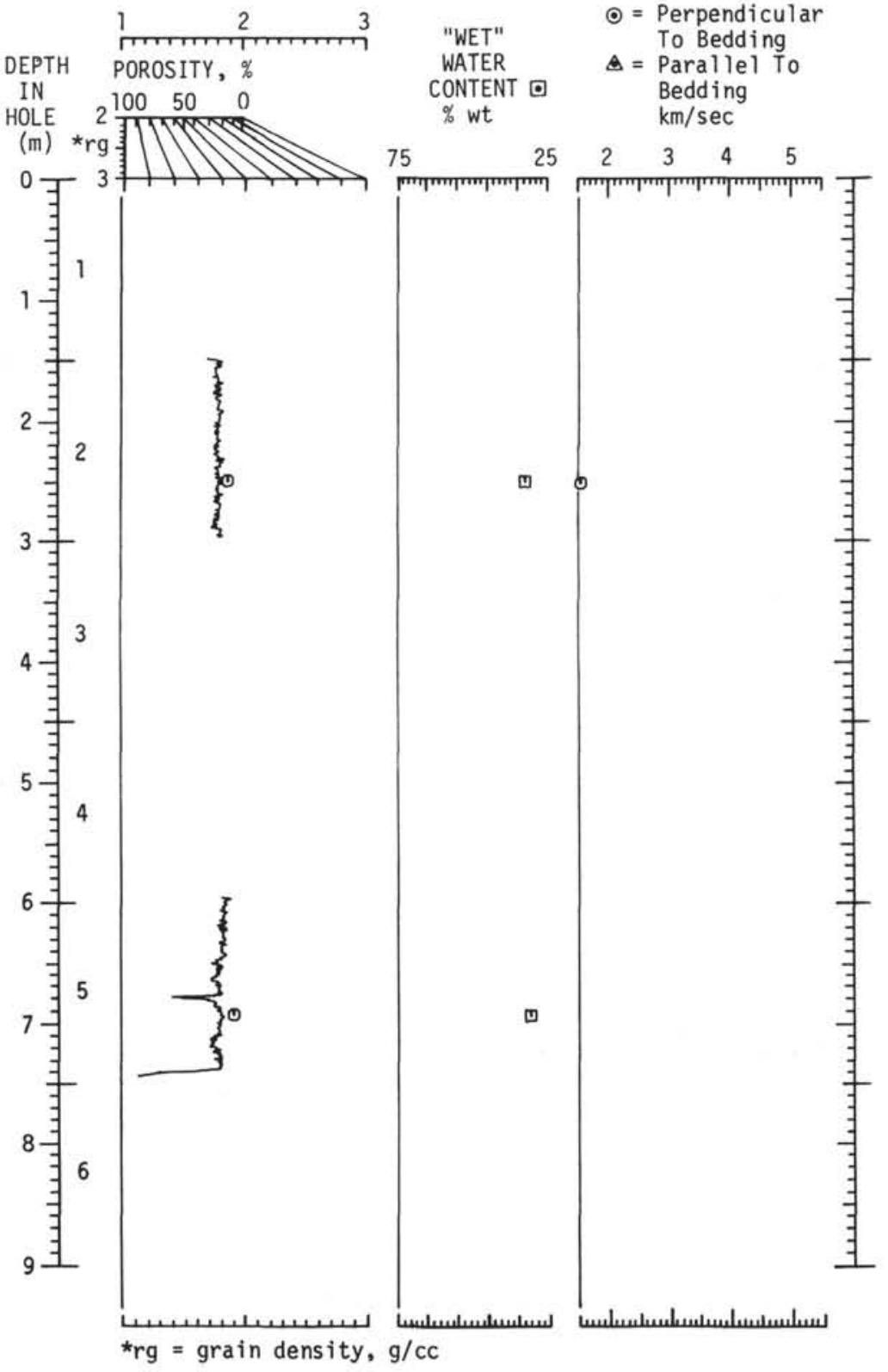


- Syringe porosity, \% COMPRESSIONAL SOUND VELOCITY

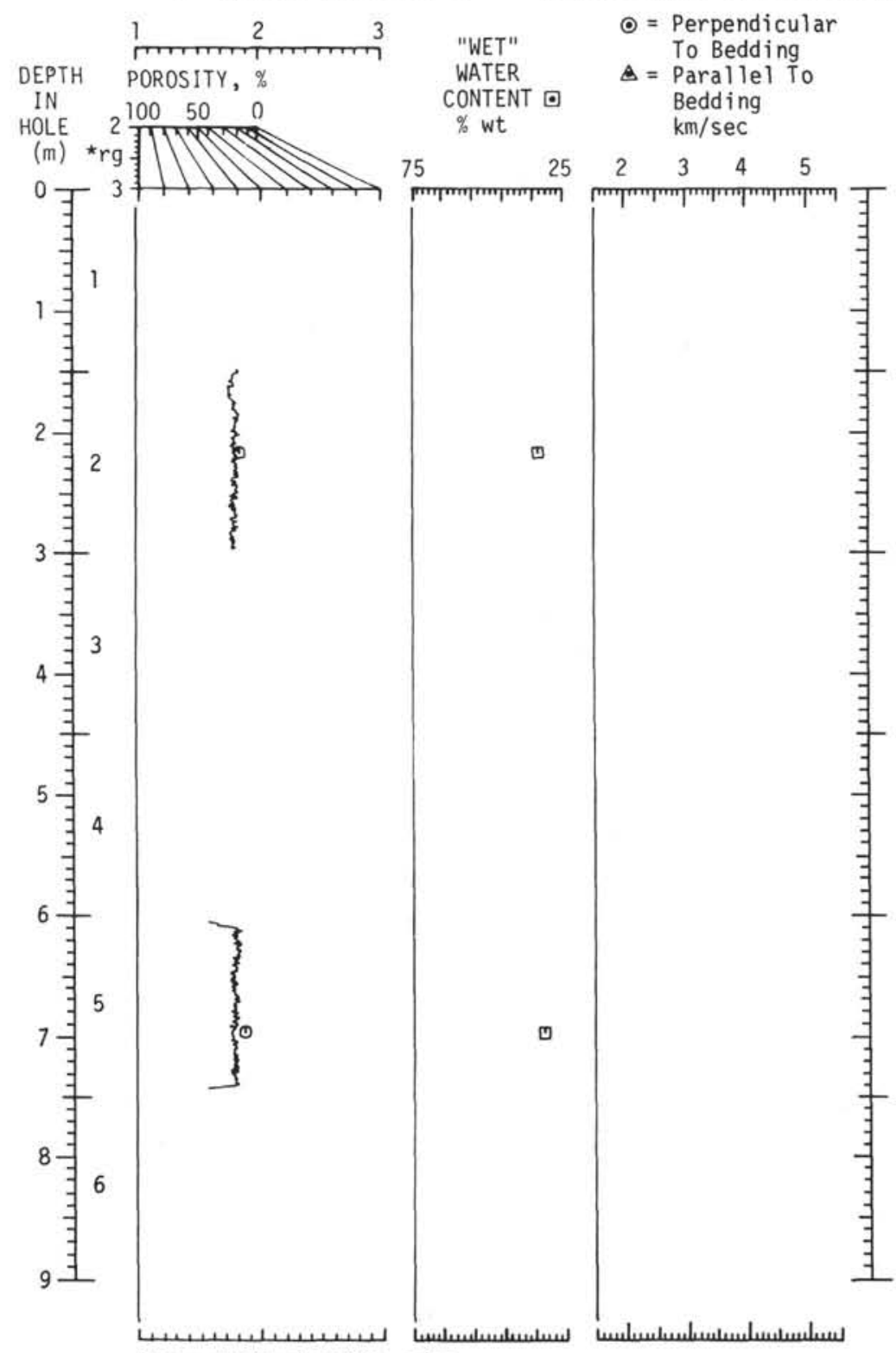

$*_{\mathrm{rg}}=$ grain density, $\mathrm{g} / \mathrm{cc}$
- $=$ GRAPE WET - BULK DENSITY, g/cC

- Syringe porosity, \% COMPRESSIONAL SOUND VELOCITY

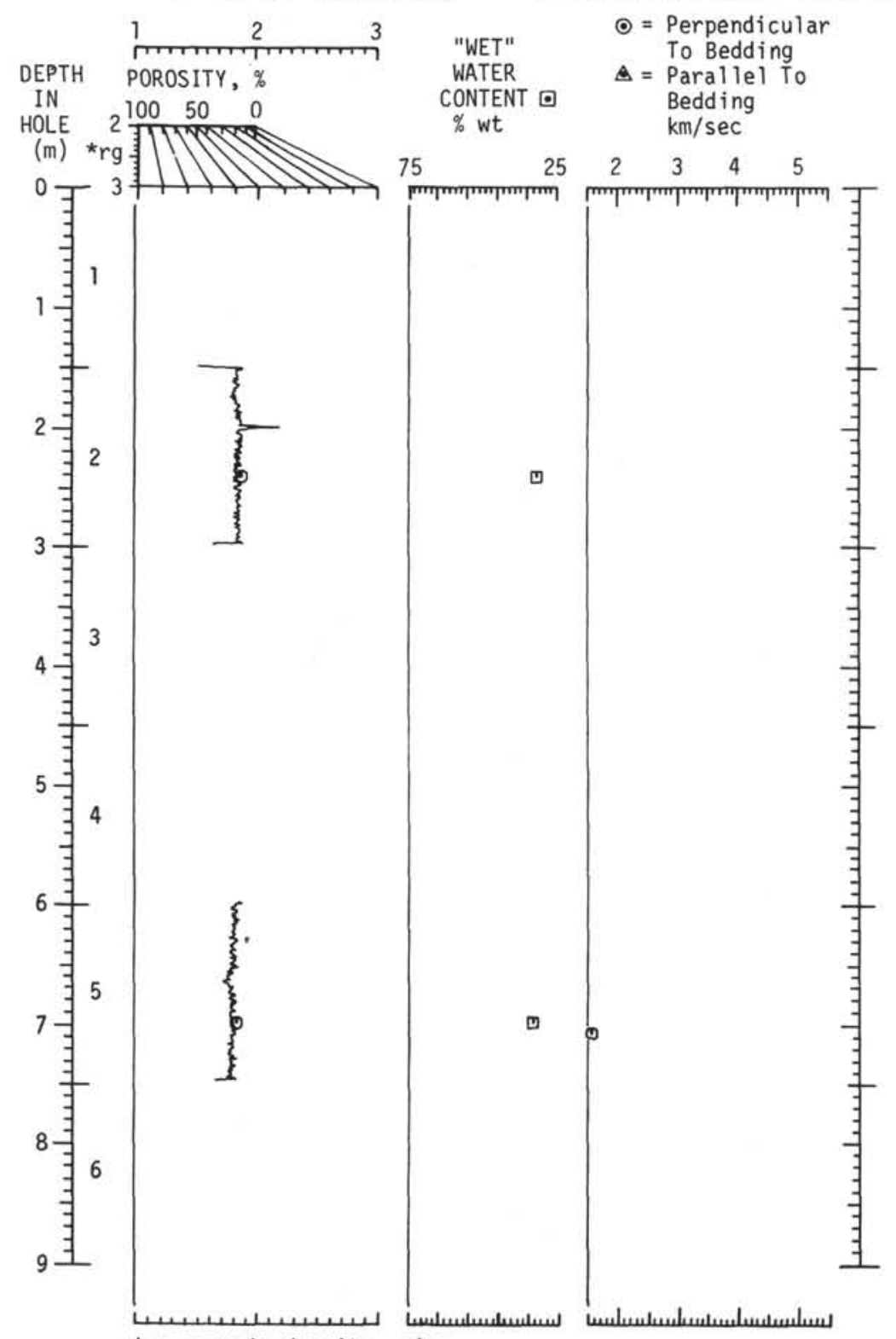

${ }^{*} \mathrm{rg}=$ grain density, $\mathrm{g} / \mathrm{cc}$ 
CORE 305-24

- = GRAPE WET-BULK DENSITY, g/cC

- Syringe porosity, \% COMPRESSIONAL SOUND VELOCITY

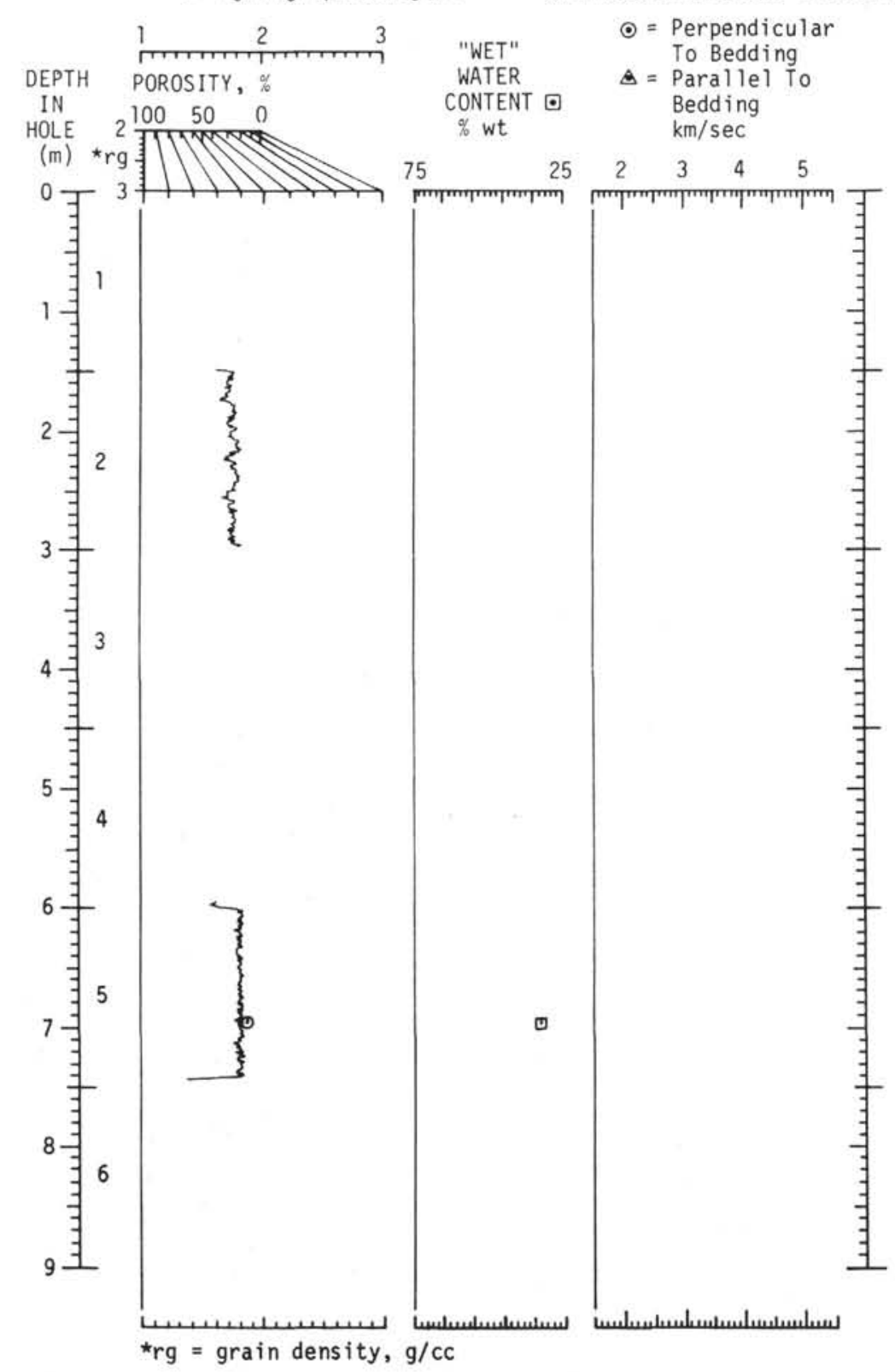

CORE 305-25

- $=$ GRAPE WET-BULK DENSITY, g/CC

- Syringe porosity, \% COMPRESSIONAL SOUND VELOCITY

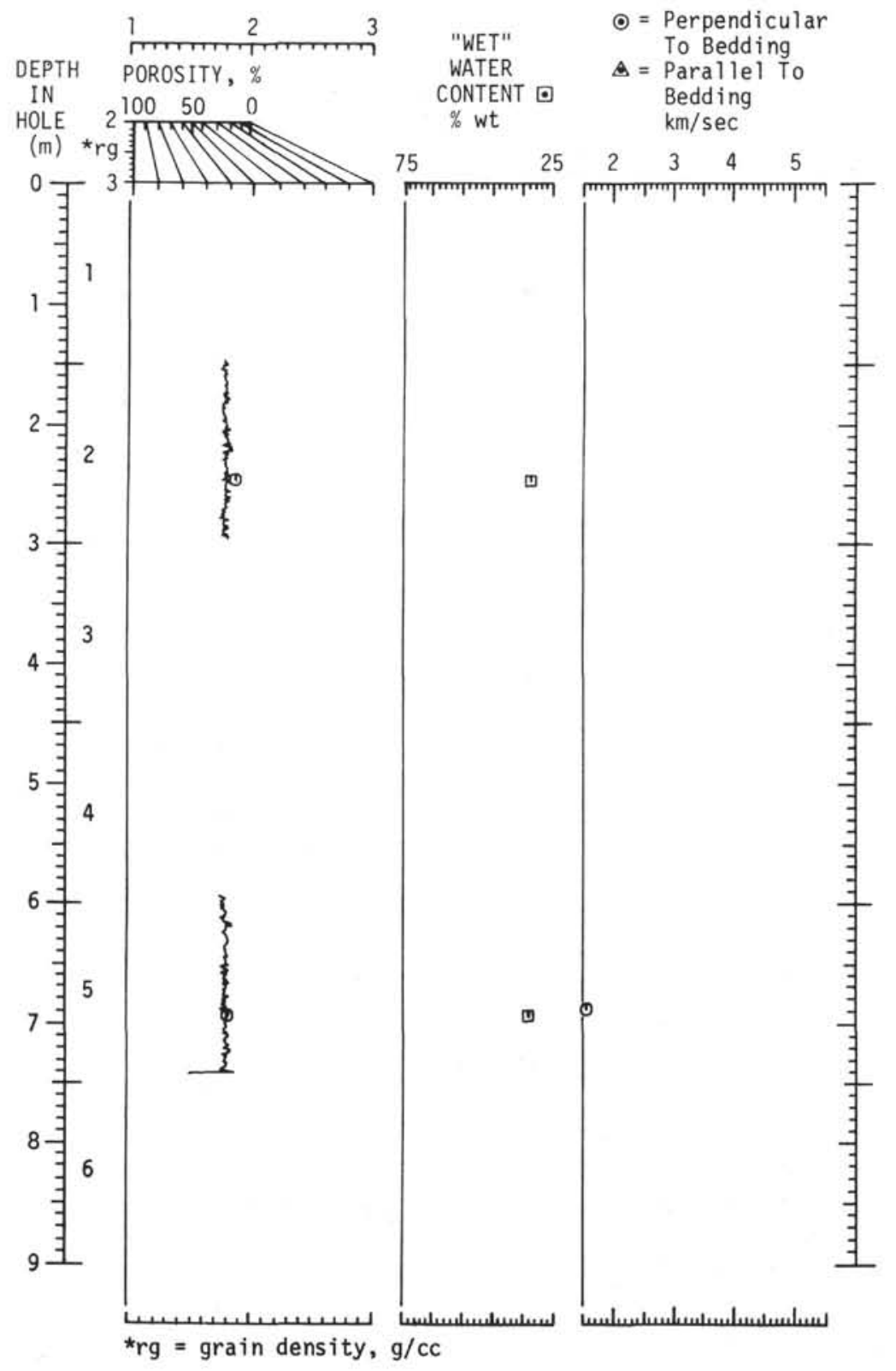


- Syringe porosity, \% COMPRESSIONAL SOUND VELOCITY

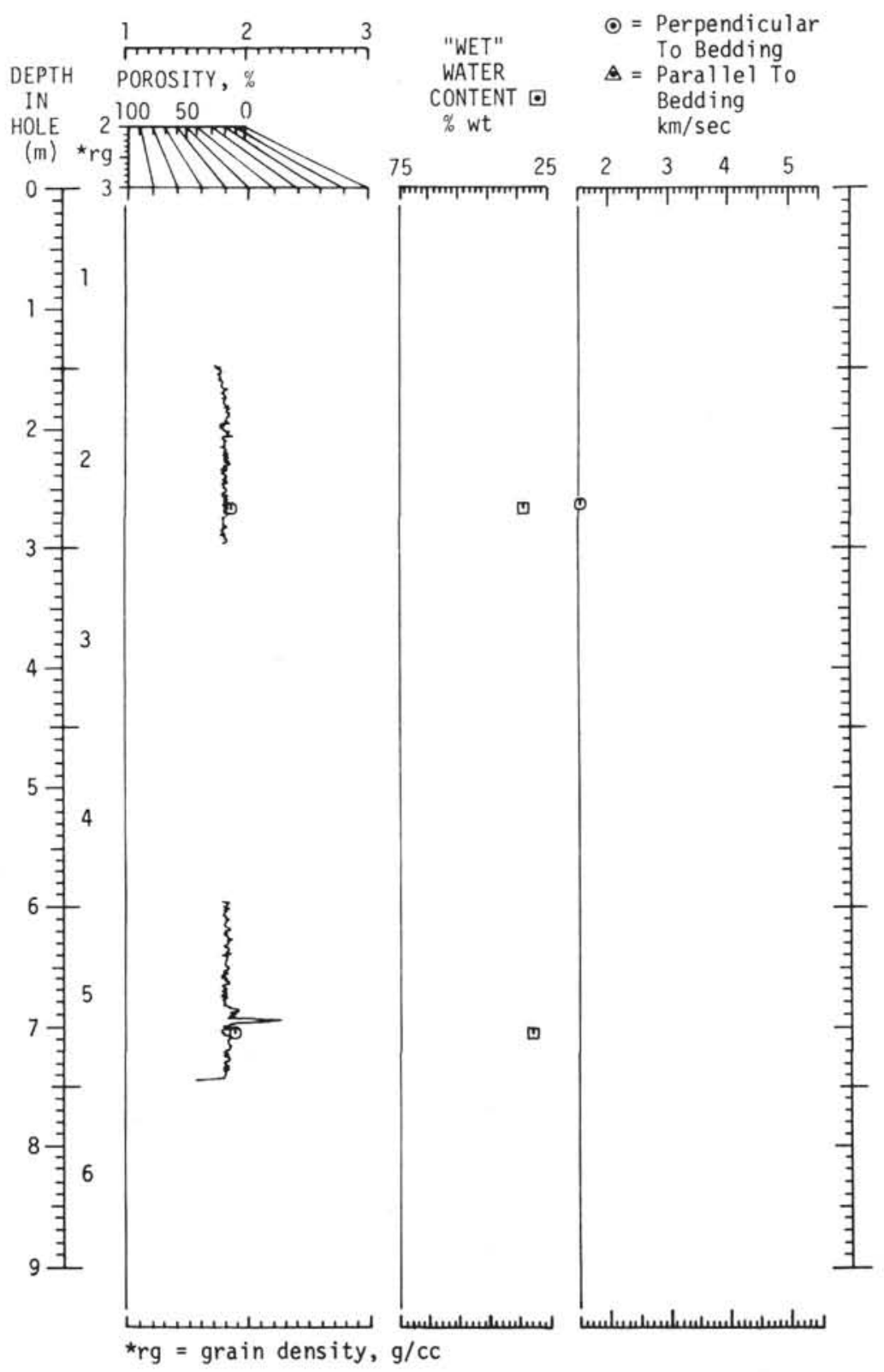

- $=$ GRAPE WET-BULK DENSITY, $\mathrm{g} / \mathrm{cC}$

- Syringe porosity, \% COMPRESSIONAL SOUND VELOCITY

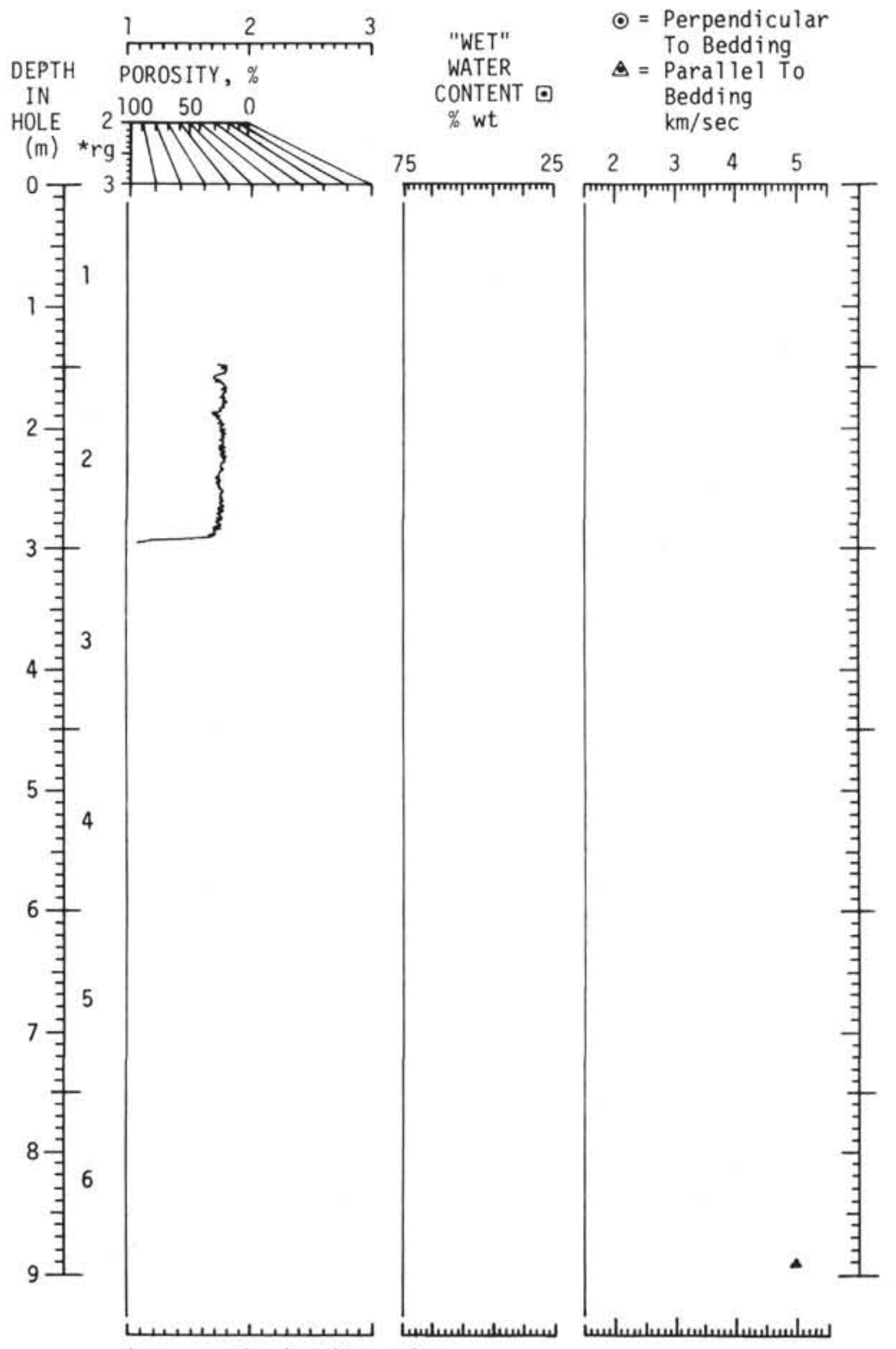

${ }^{\star} r g=$ grain density, $g / c c$ 
CORE $305-34$

$-=$ GRAPE WET-BULK DENSITY, $\mathrm{g} / \mathrm{CC}$

- Syringe porosity, \%

COMPRESSIONAL SOUND VELOCITY

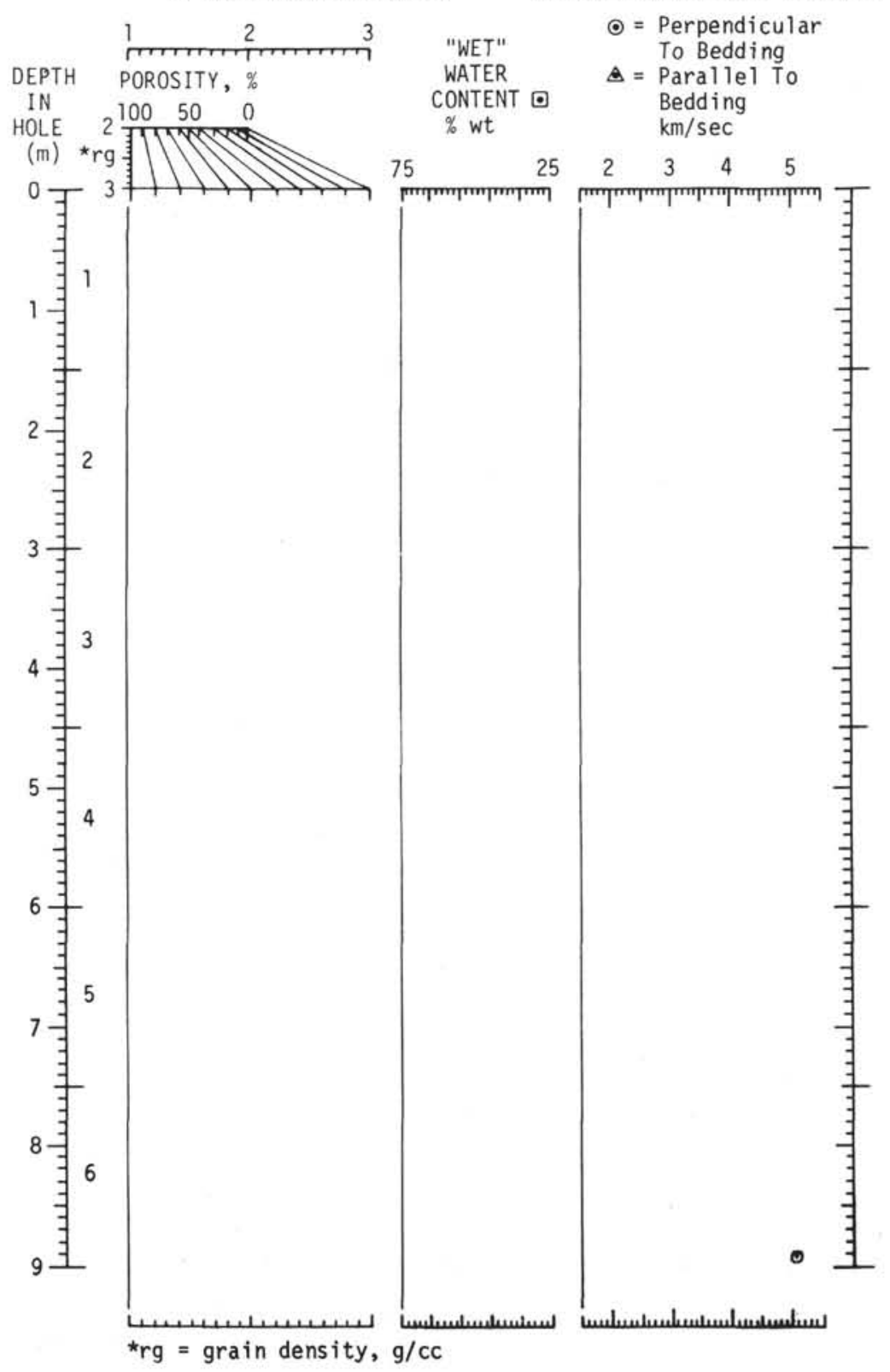

CORE 305-47

\section{$-=$ GRAPE WET-BULK DENSITY, $\mathrm{g} / \mathrm{cC}$}

- Syringe porosity, \% COMPRESSIONAL SOUND VELOCITY

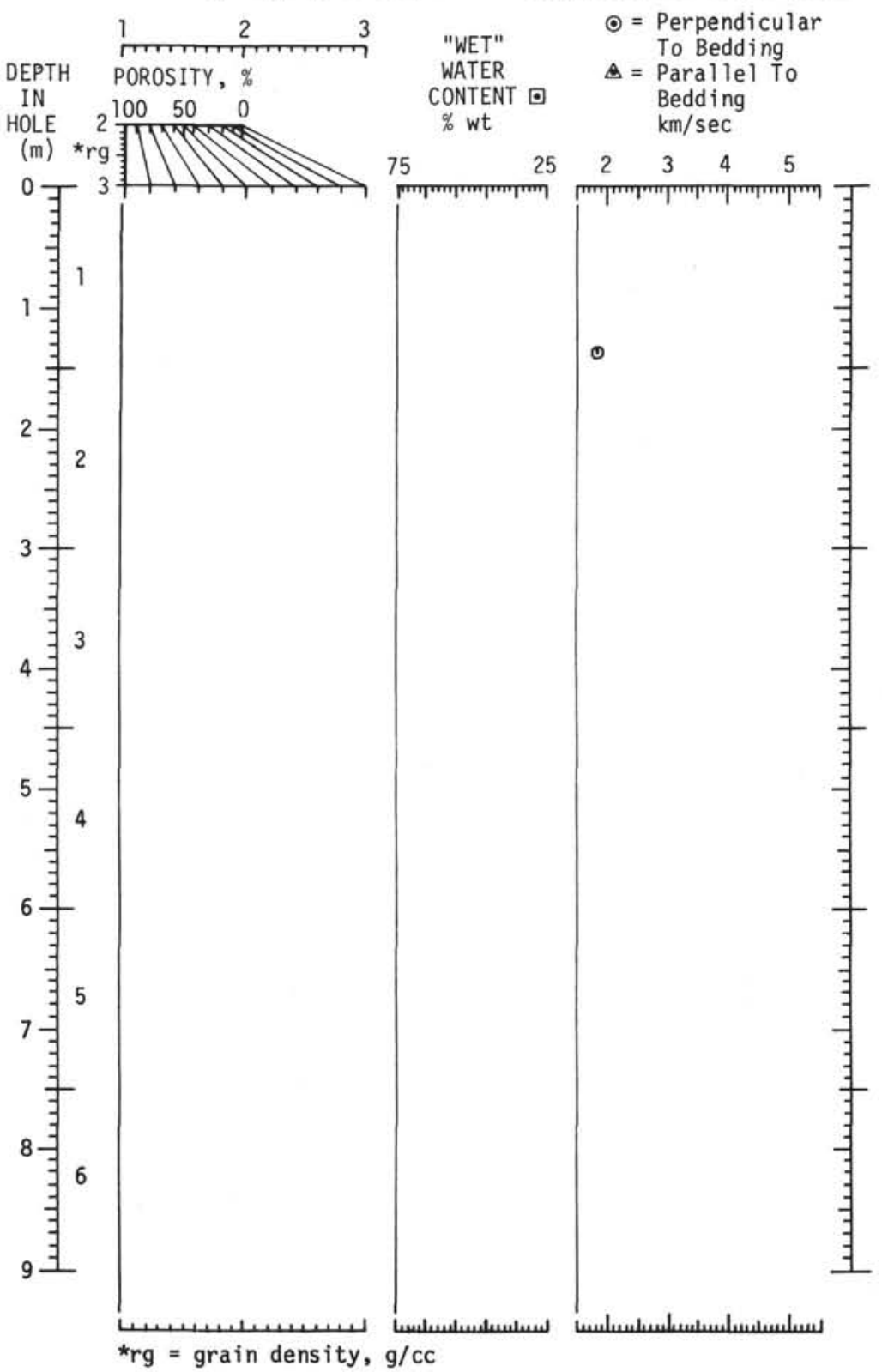


- Syringe porosity, \% COMPRESSIONAL SOUND VELOCITY

○ Syringe porosity, \% COMPRESSIONAL SOUND VELOCITY
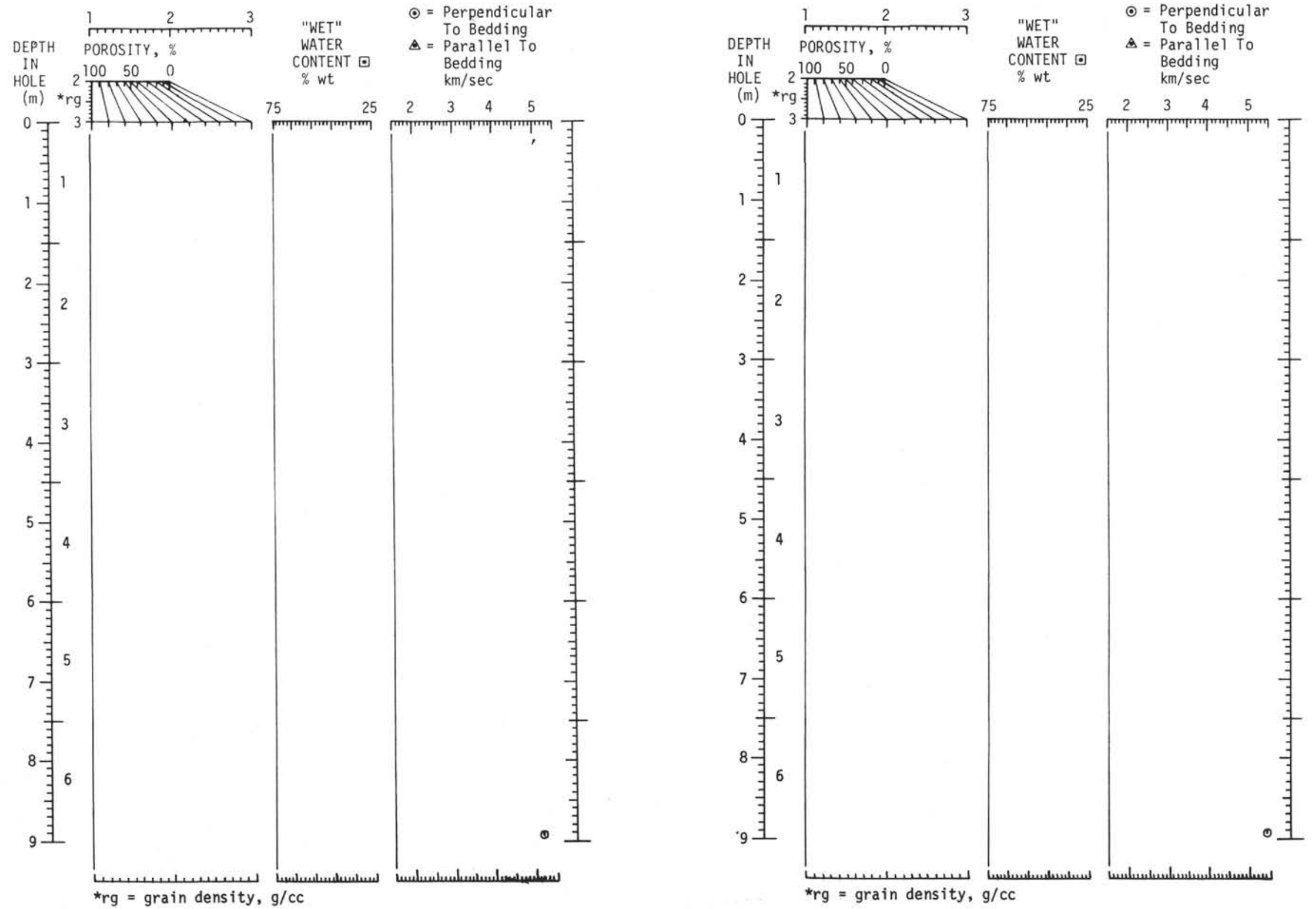
CORE $305-59$

- $=$ GRAPE WET-BULK DENSITY, $g / c C$

- Syringe porosity, \% COMPRESSIONAL SOUND VELOCITY

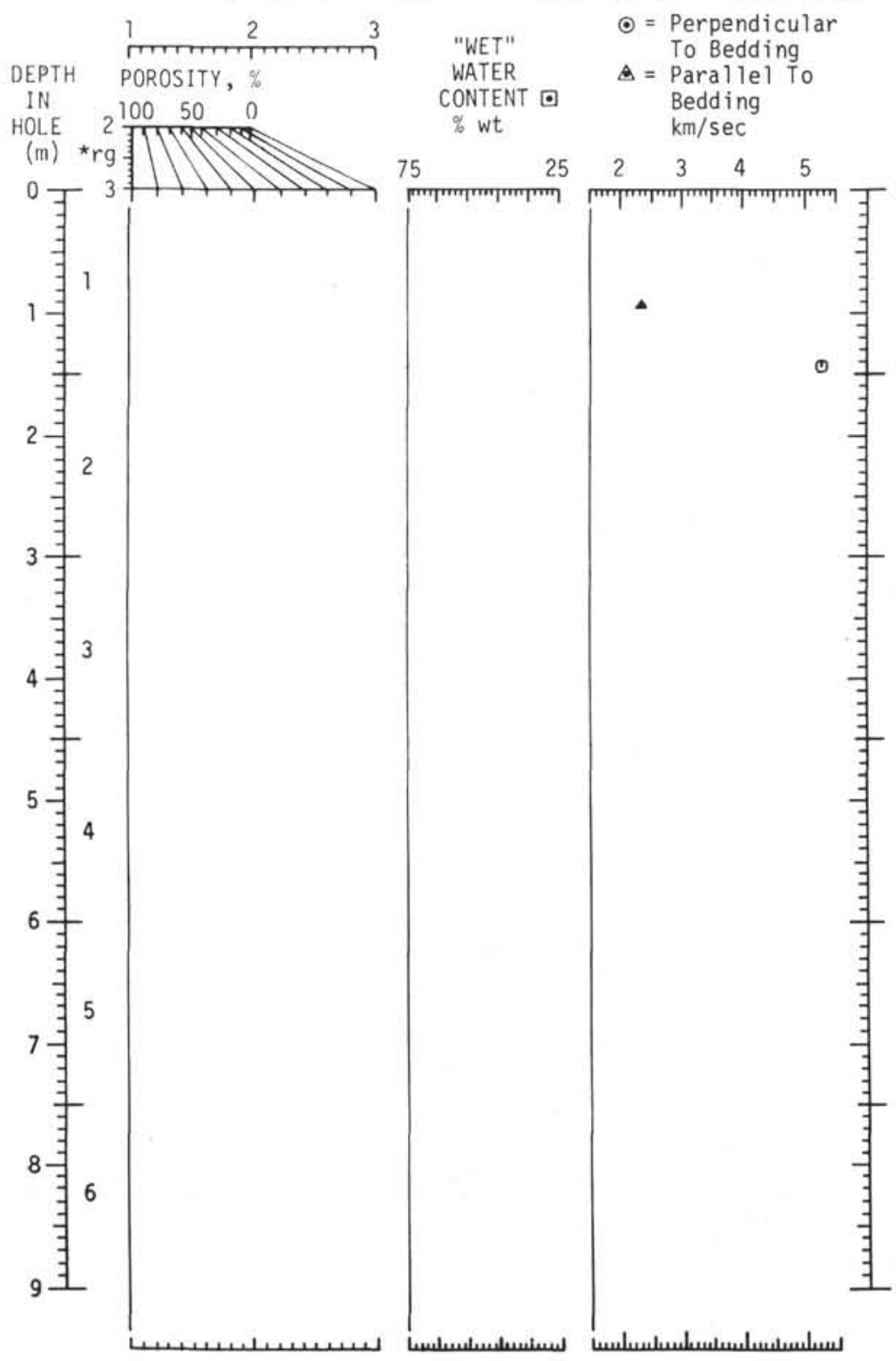

CORE 305-61

- $=$ GRAPE WET-BULK DENSITY, $\mathrm{g} / \mathrm{cc}$

๑ Syringe porosity, \%

COMPRESSIONAL SOUND VELOCITY

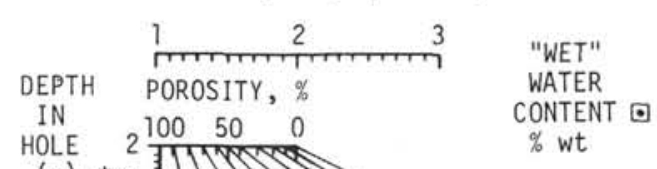

$\odot=$ Perpendicular

To Bedding

$=$ Parallel To

Bedding

HOLE 2 TIM 50 \%

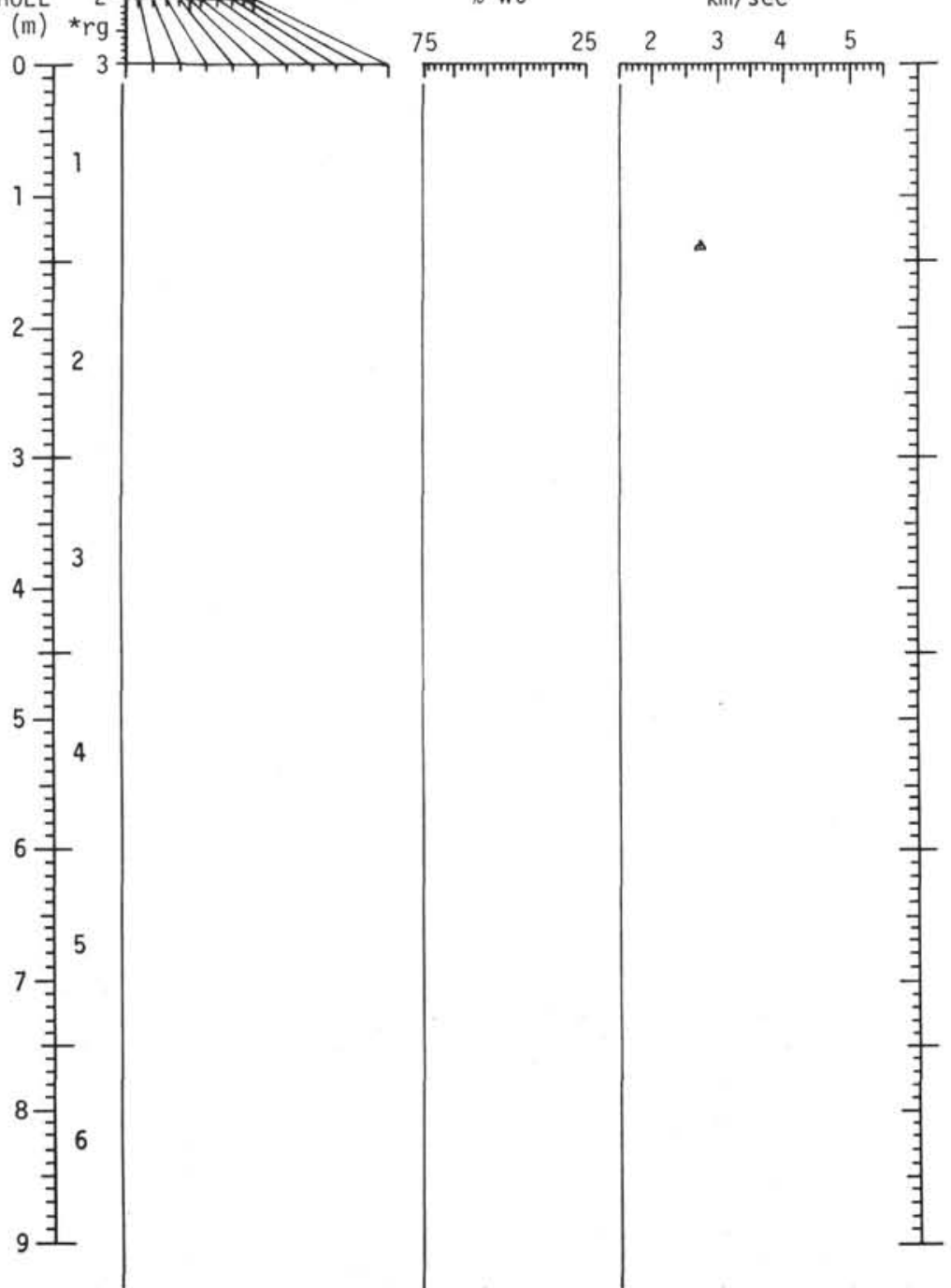

Lبسبسm

${ }^{*} r g=$ grain density, $g / c c$ 
- Syringe porosity, \% COMPRESSIONAL SOUND VELOCITY

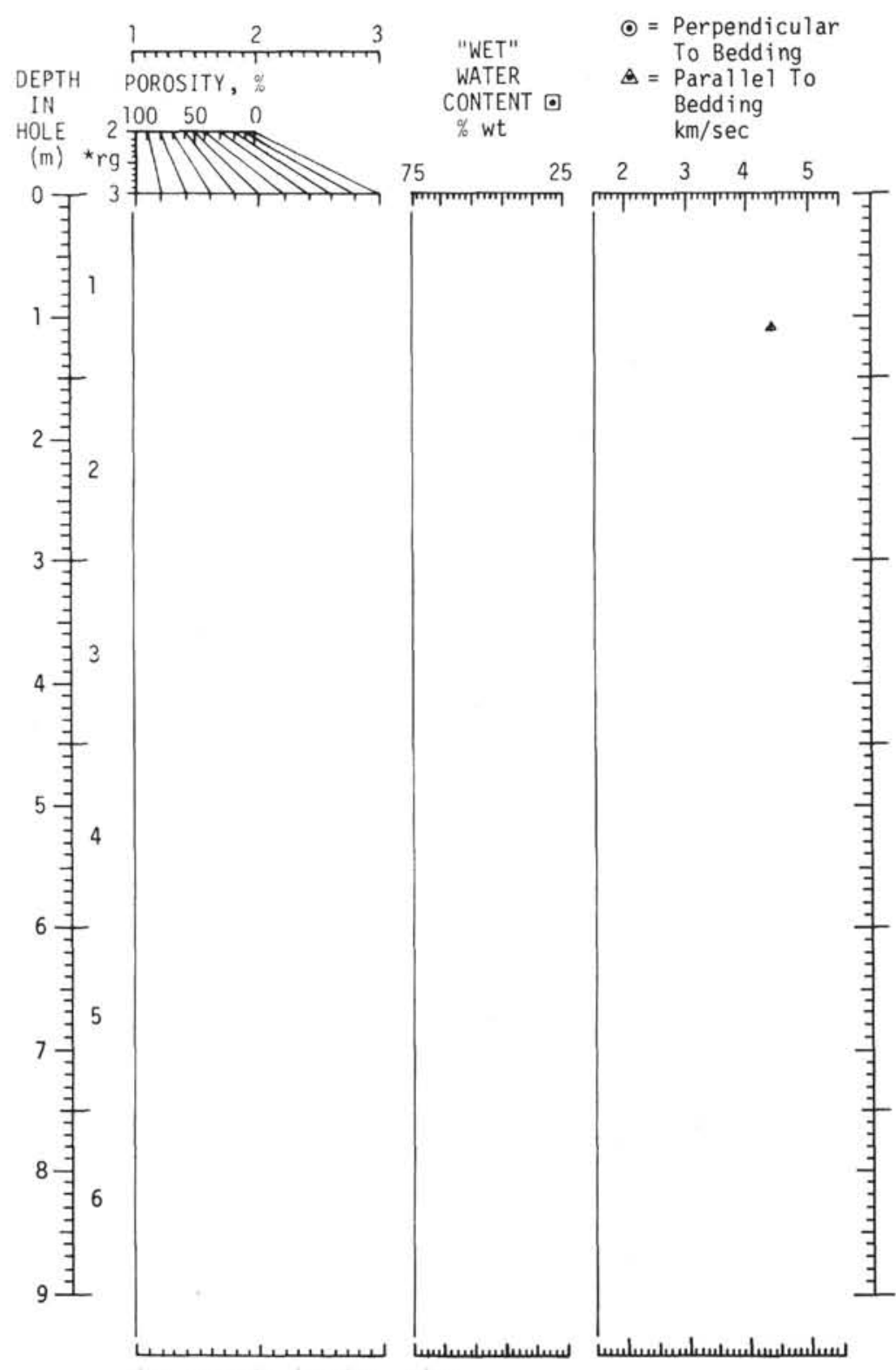

- $=$ GRAPE WET-BULK DENSITY, $g / c c$

- Syringe porosity, \% COMPRESSIONAL SOUND VELOCITY

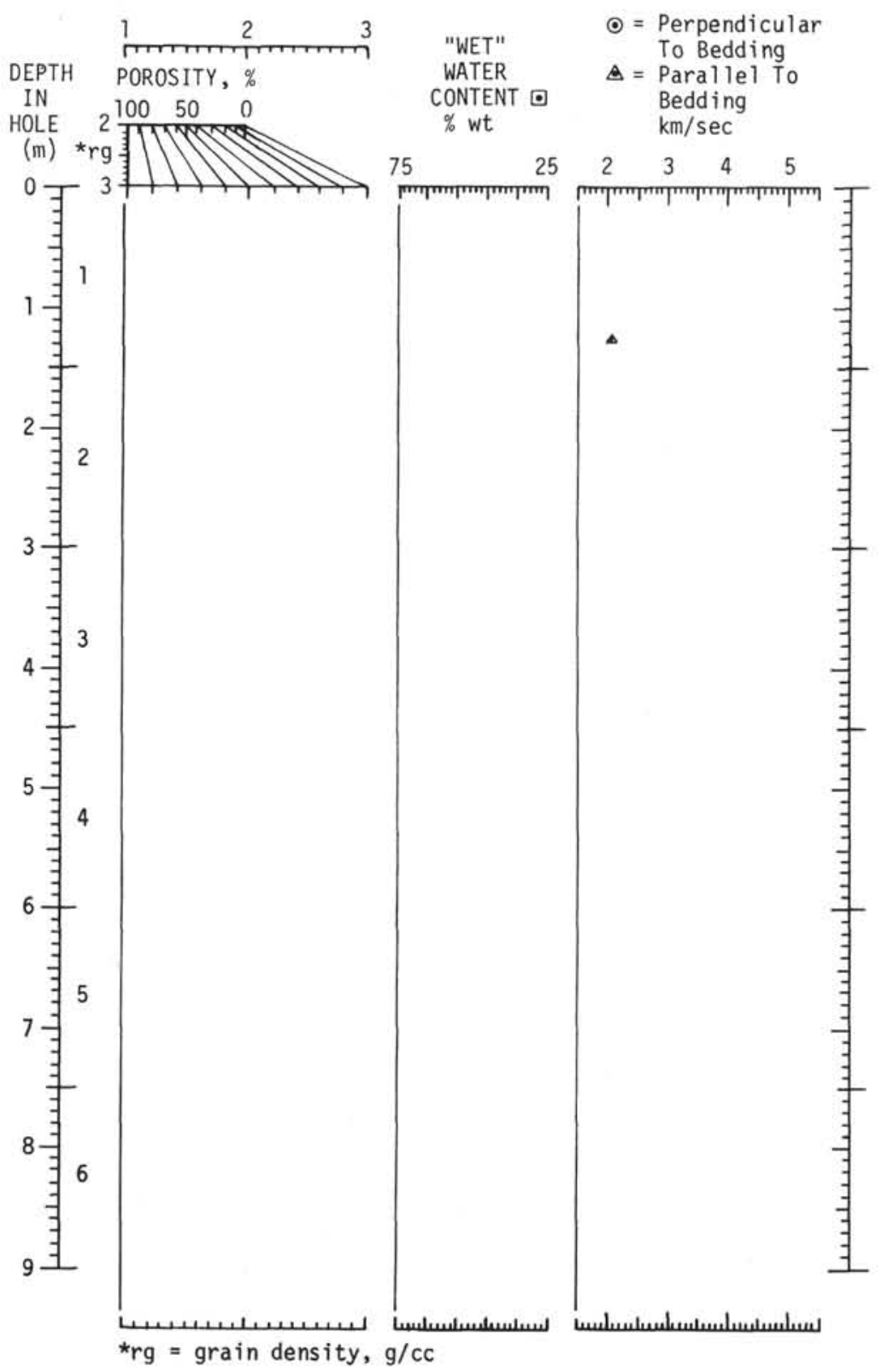


CORE 305-65

- $=$ GRAPE WET-BULK DENSITY, $\mathrm{g} / \mathrm{cC}$

- Syringe porosity, \%

COMPRESSIONAL SOUND VELOCITY

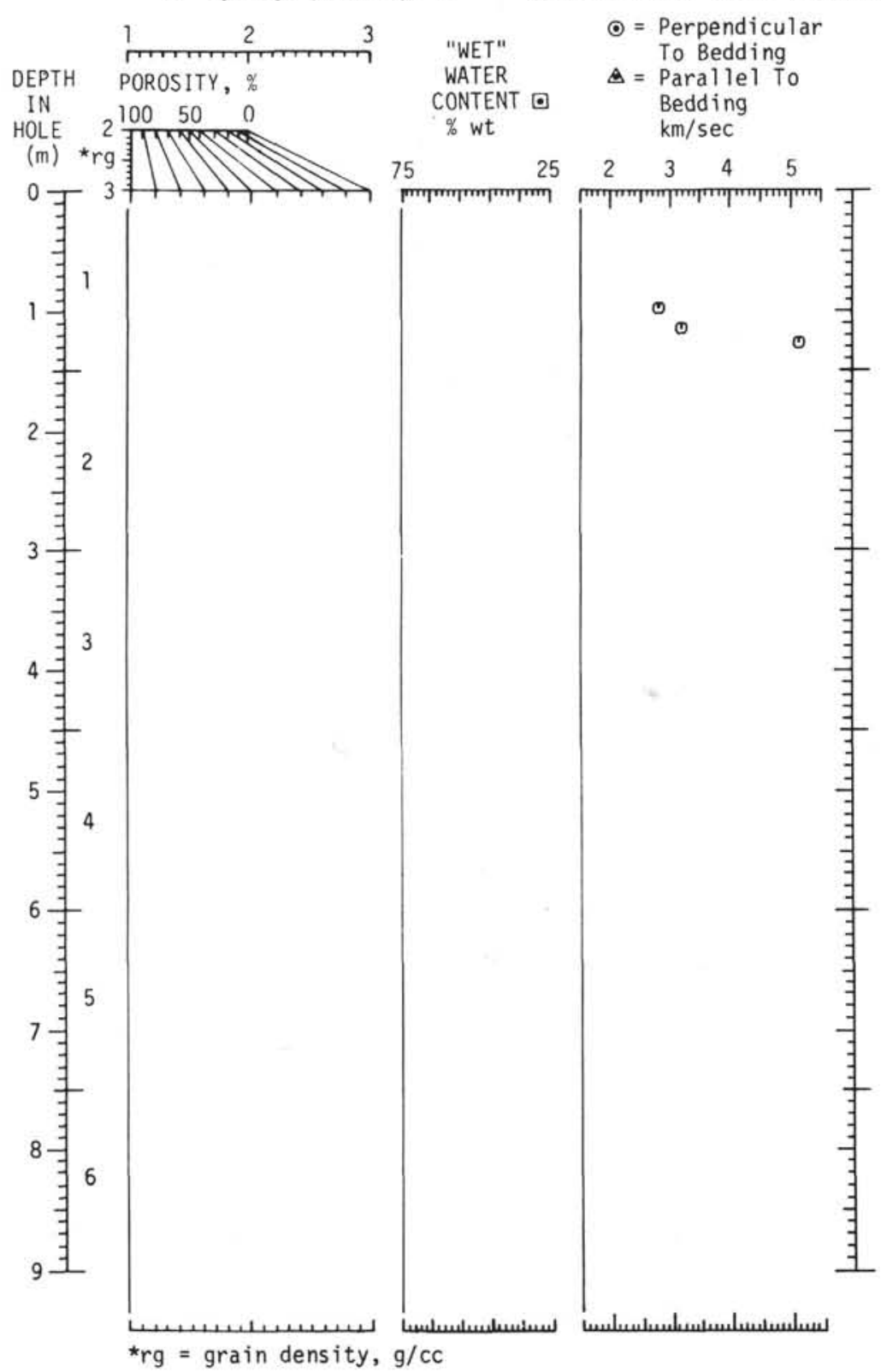

$\odot=$ Perpendicular

To Bedding

将

$\exists$

更

羊

-

$\exists$$$
\text { . }
$$

CORE $305-66$

$$
\text { - = GRAPE WET }- \text { BULK DENSITY, g/cc }
$$

- Syringe porosity, \% COMPRESSIONAL SOUND VELOCITY

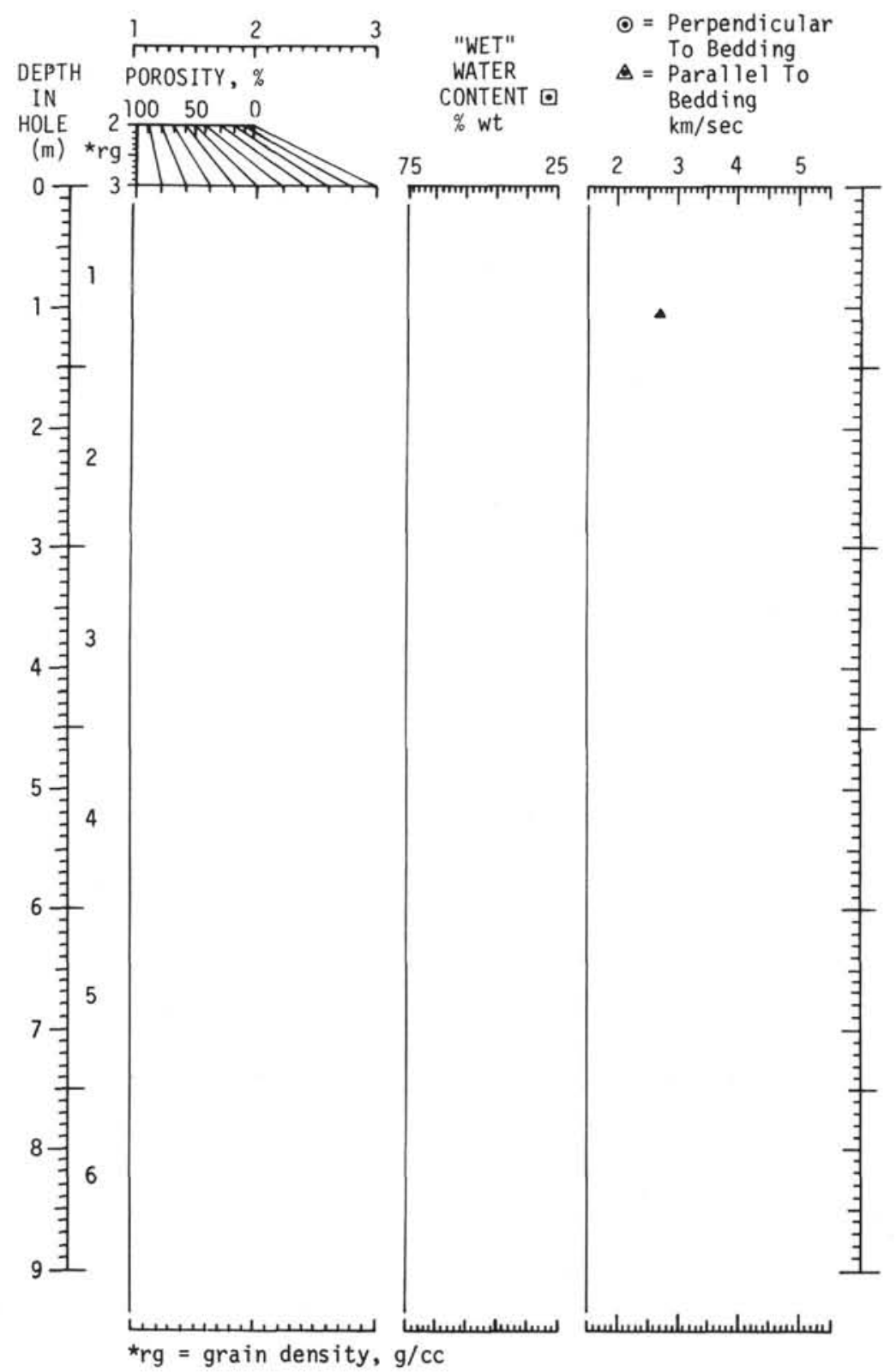




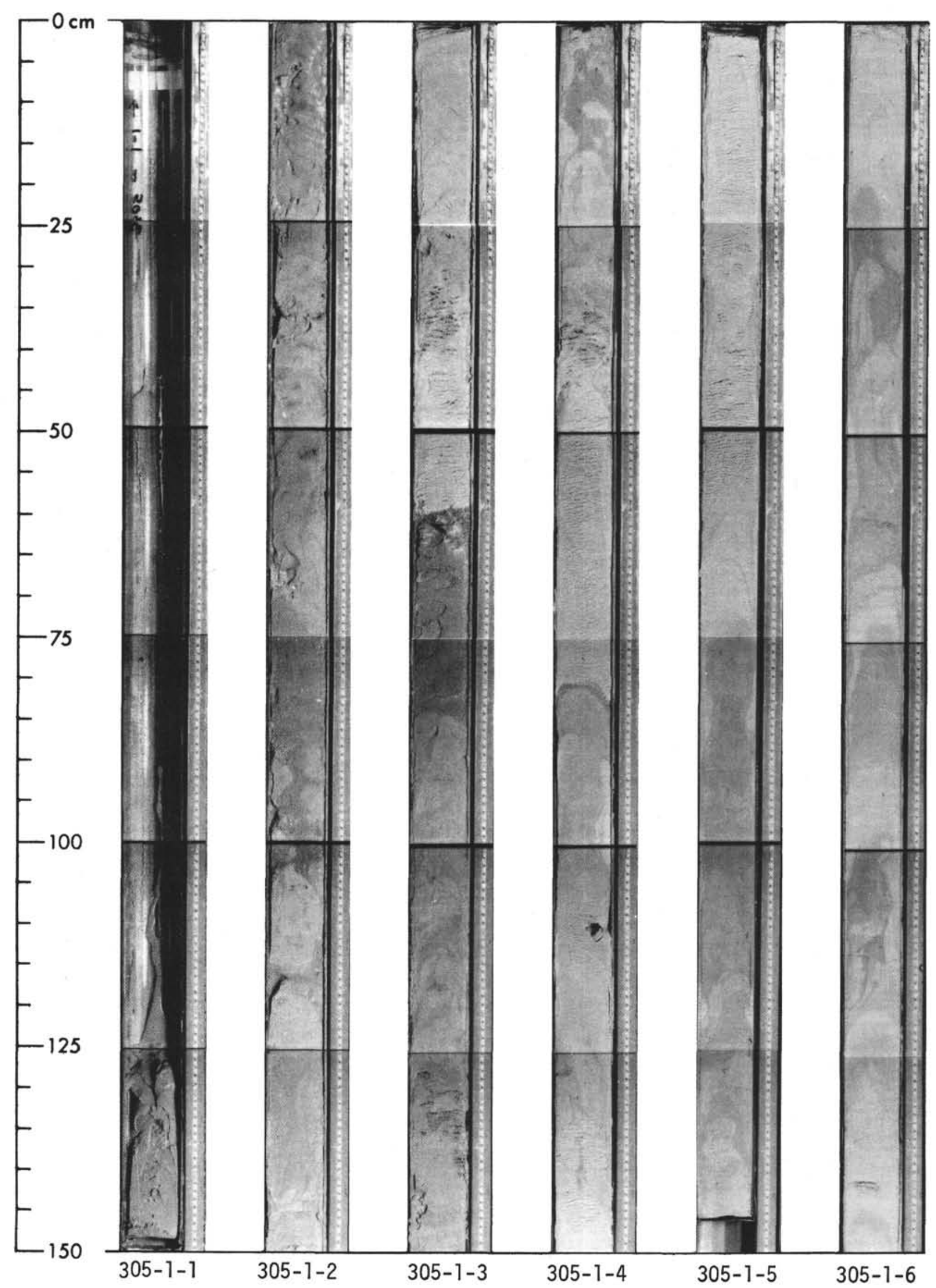




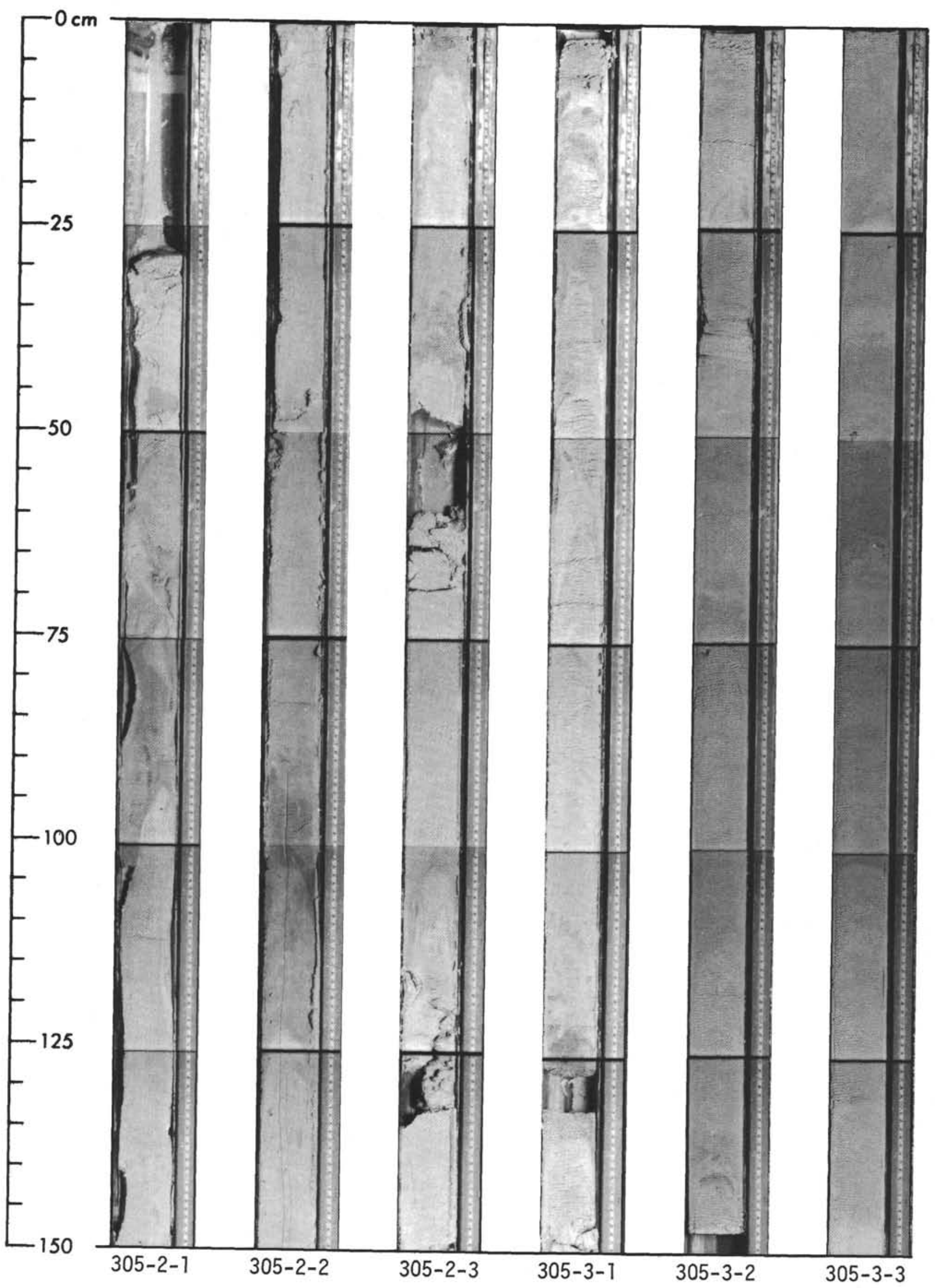




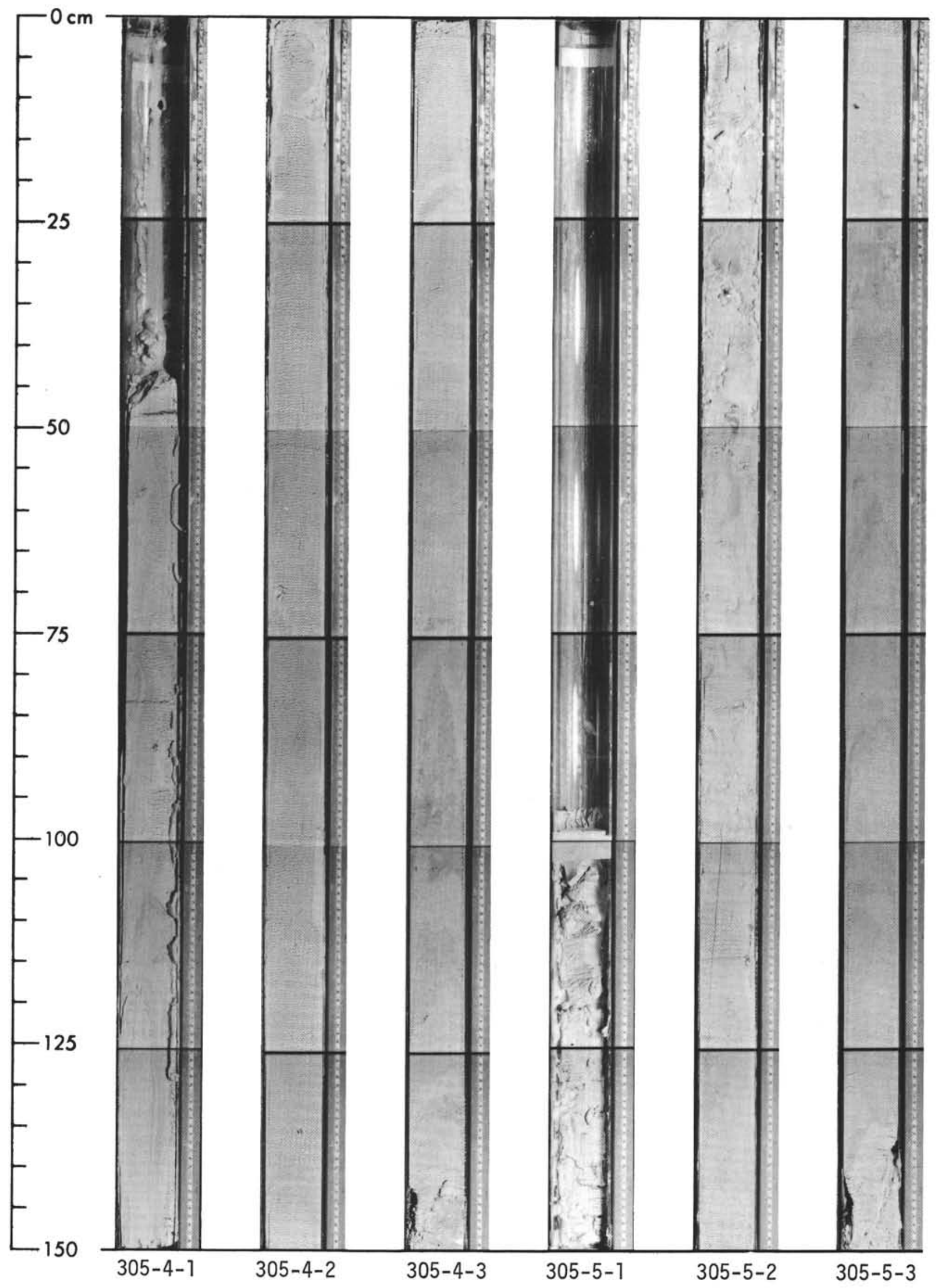




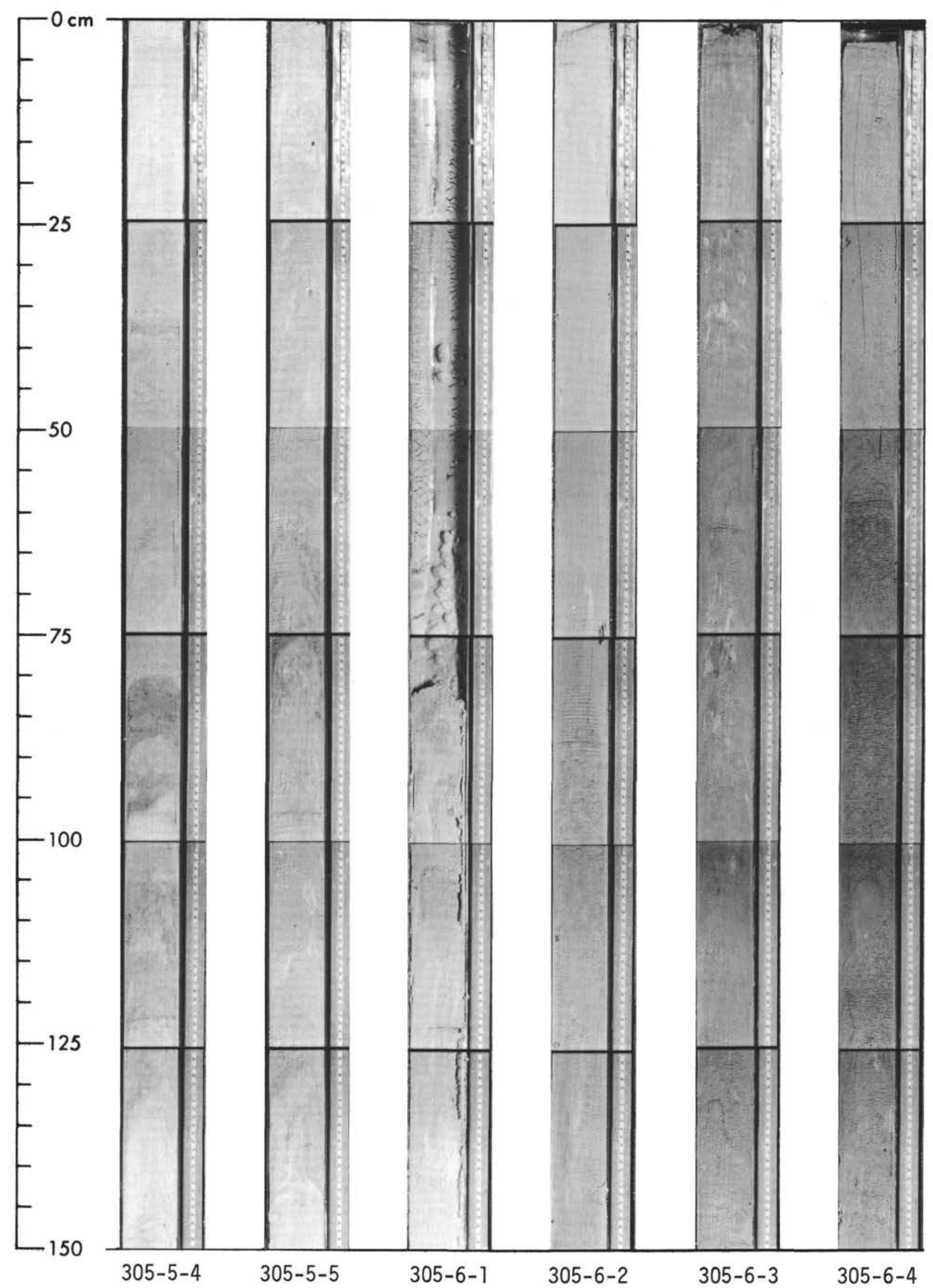




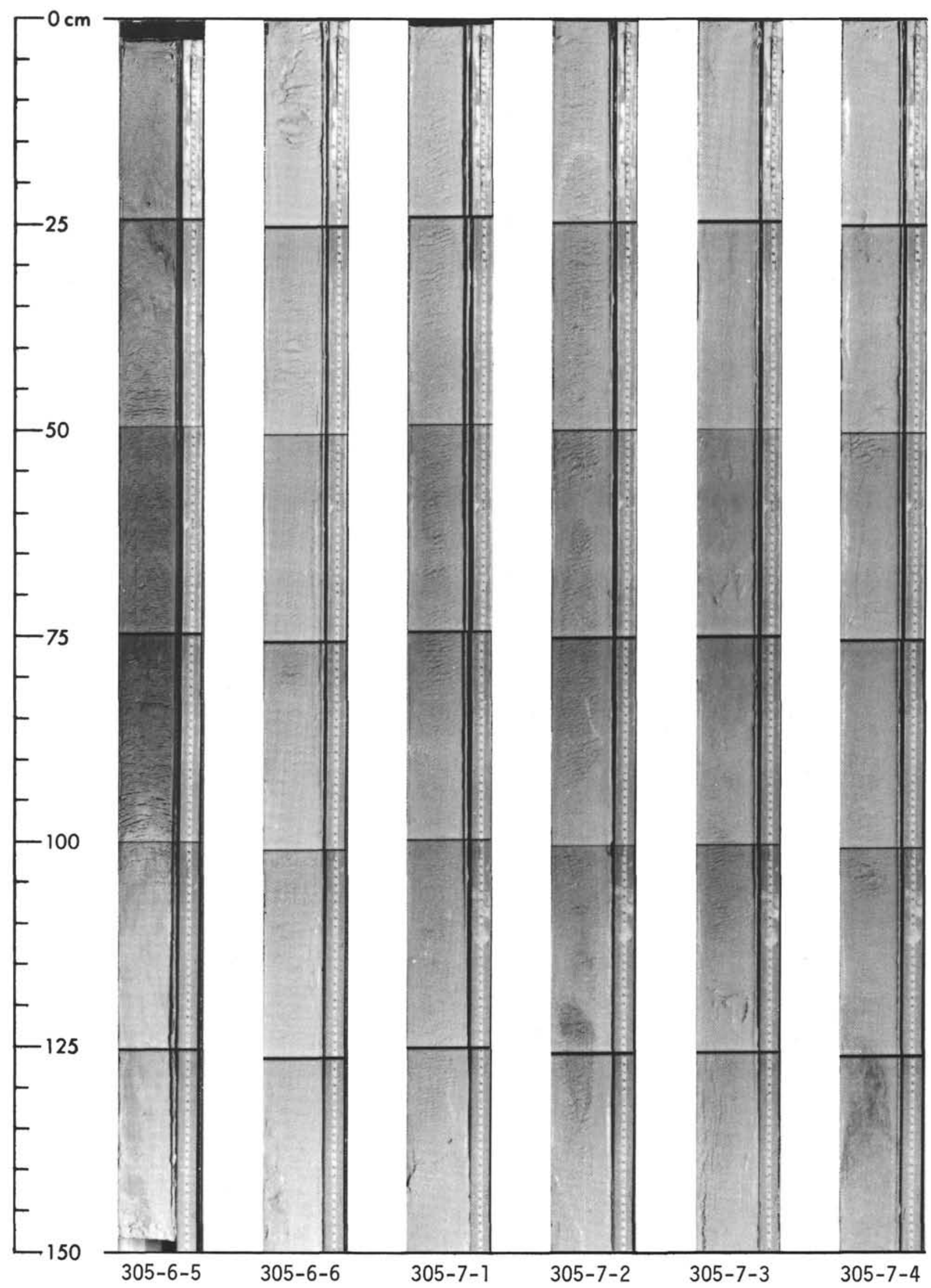




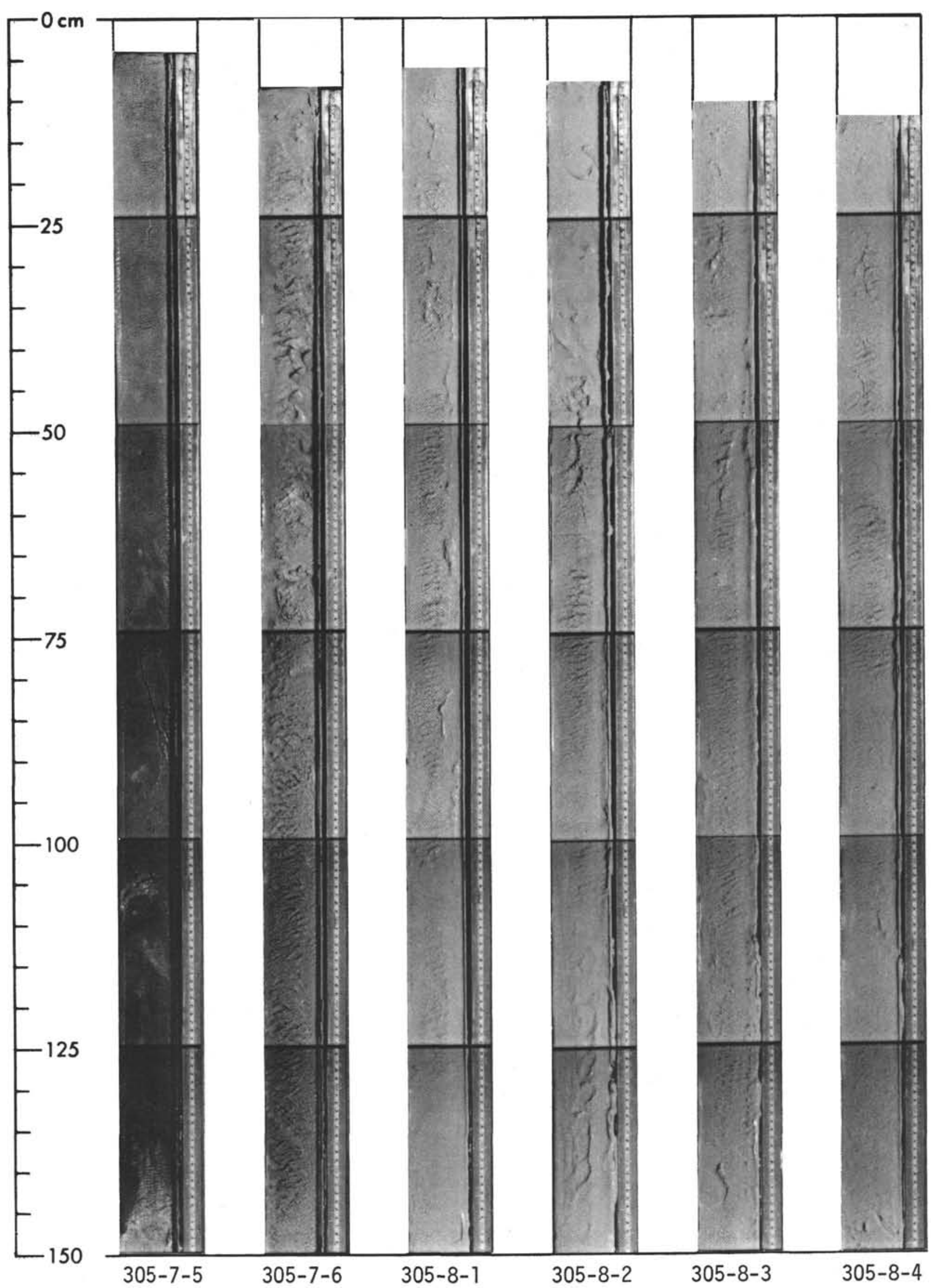




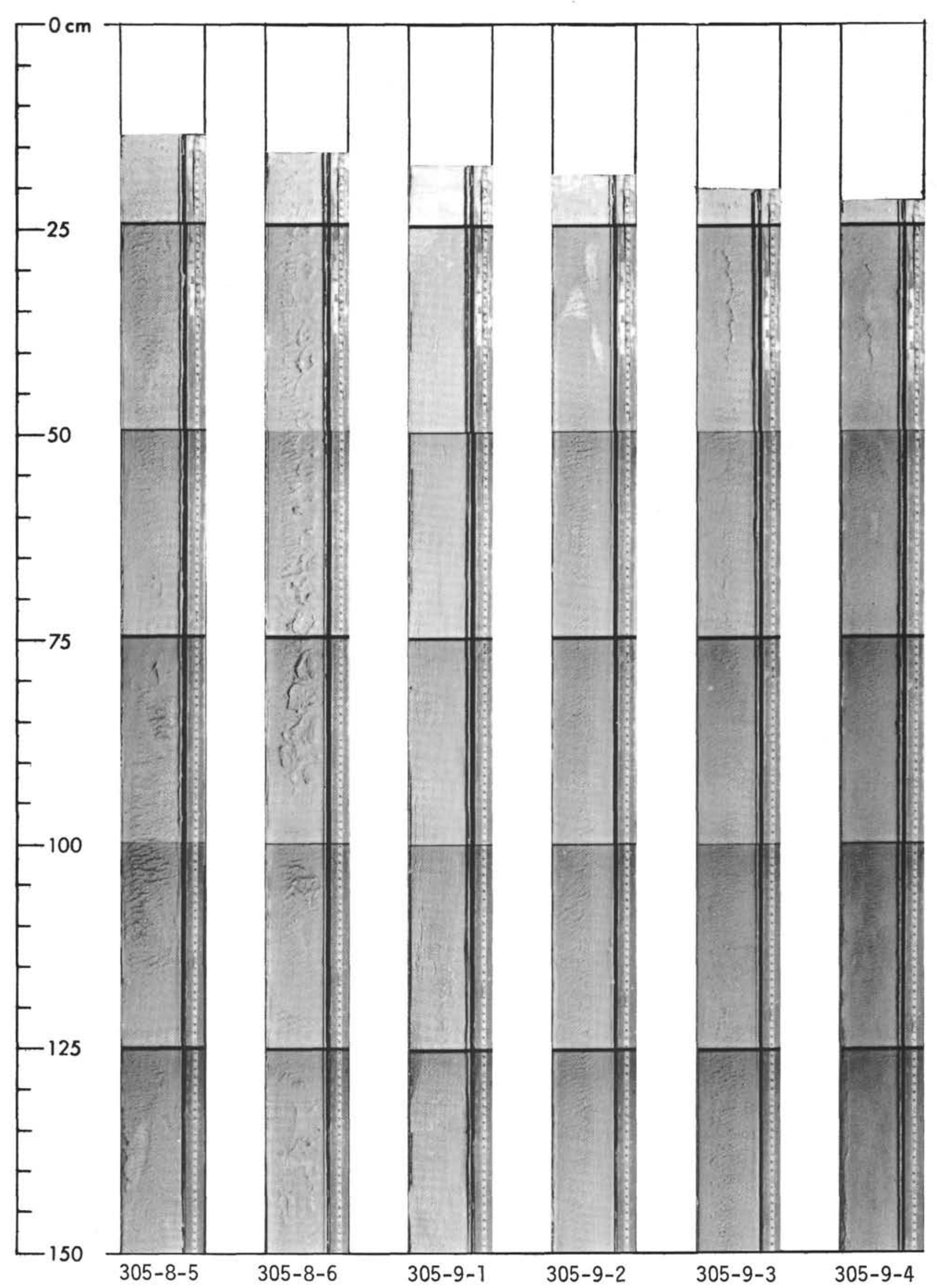




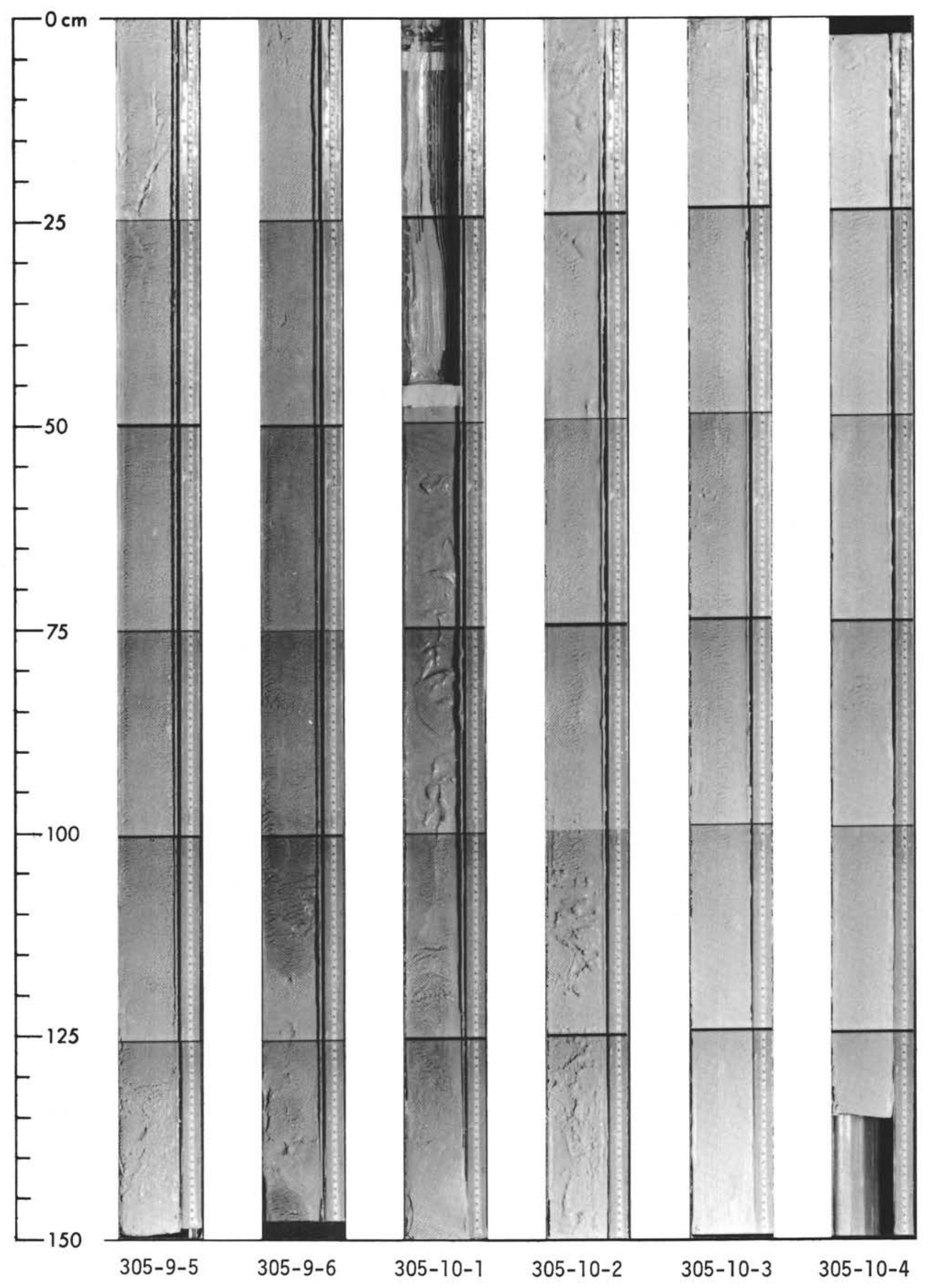




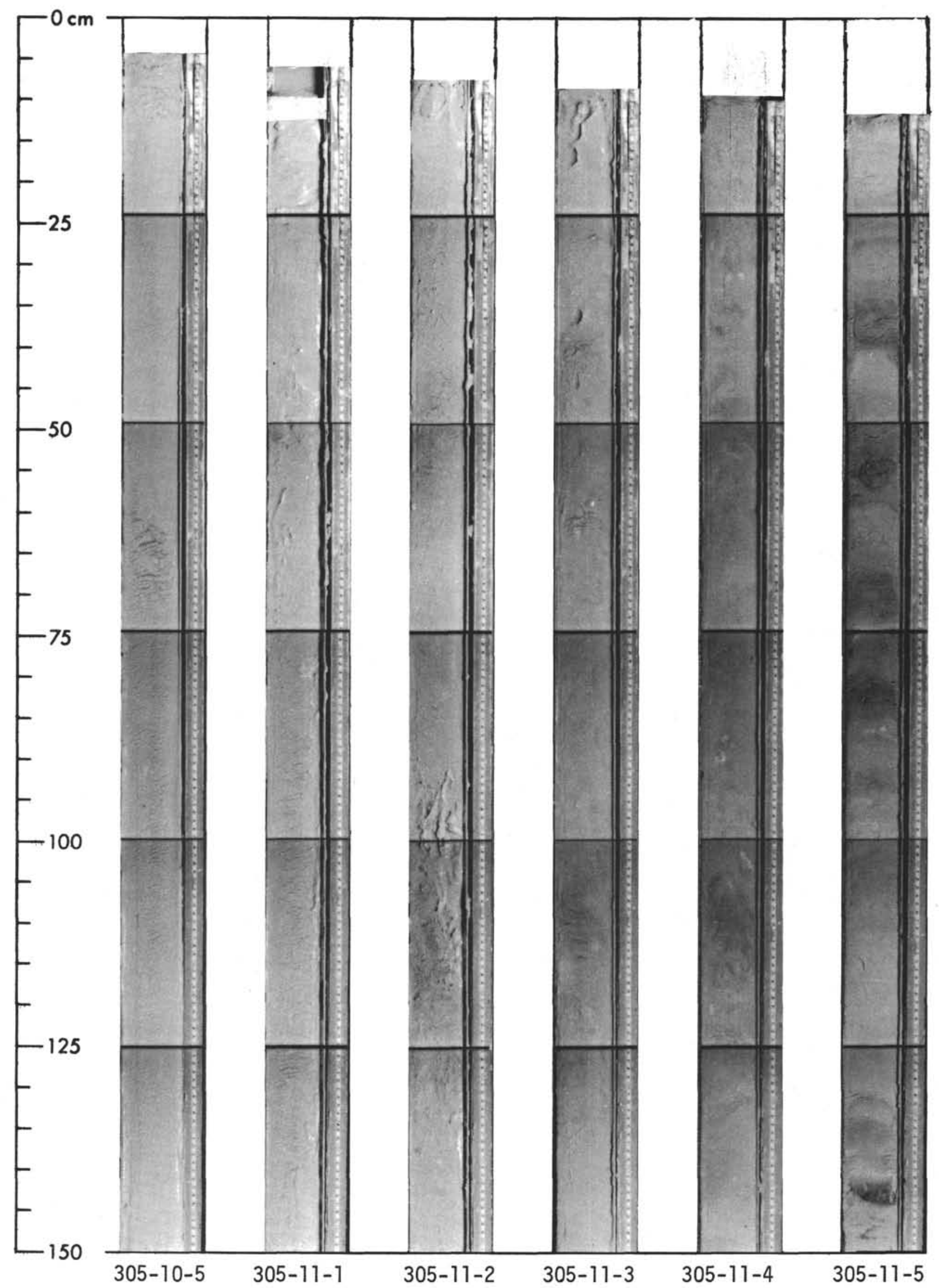




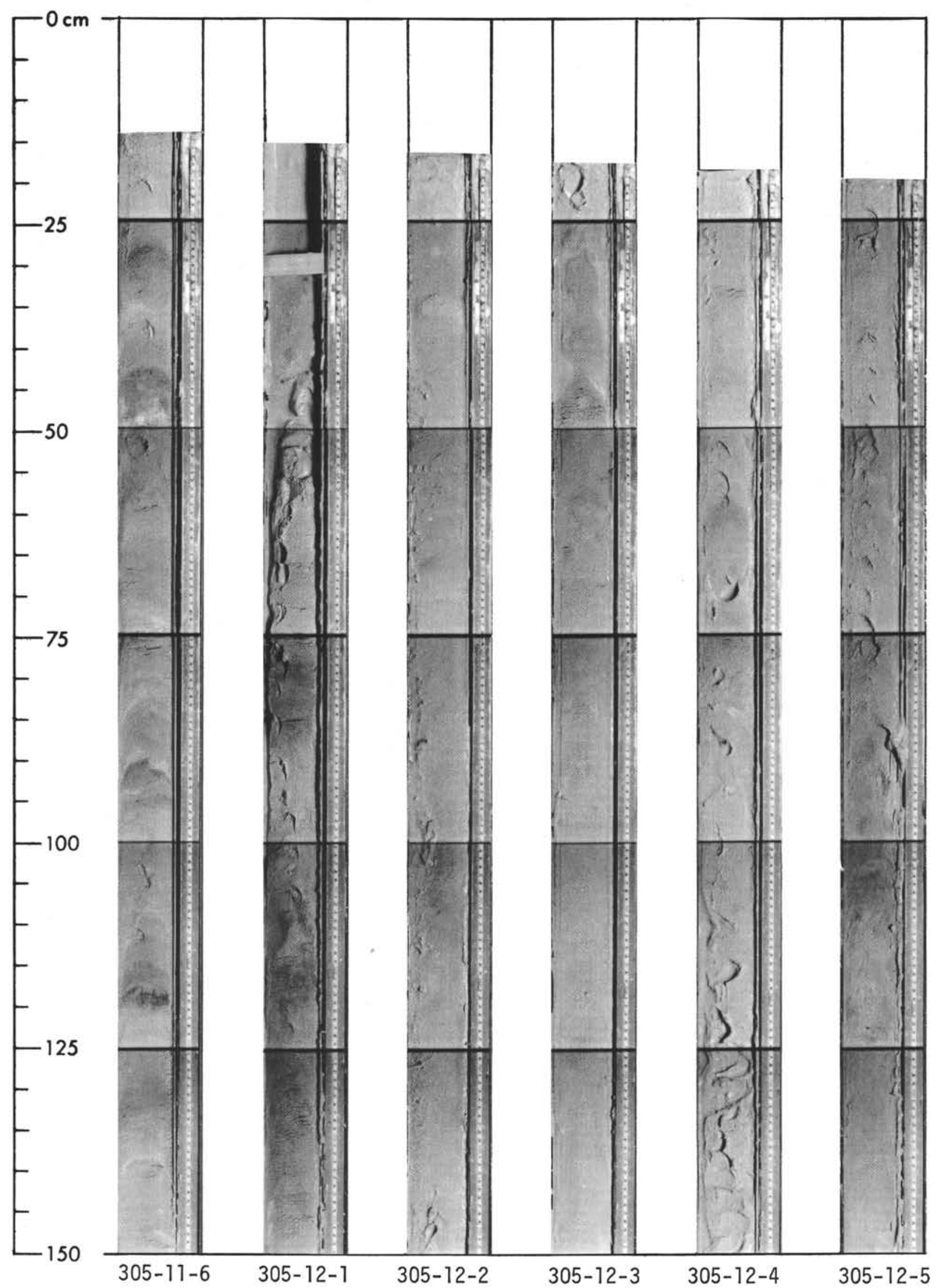




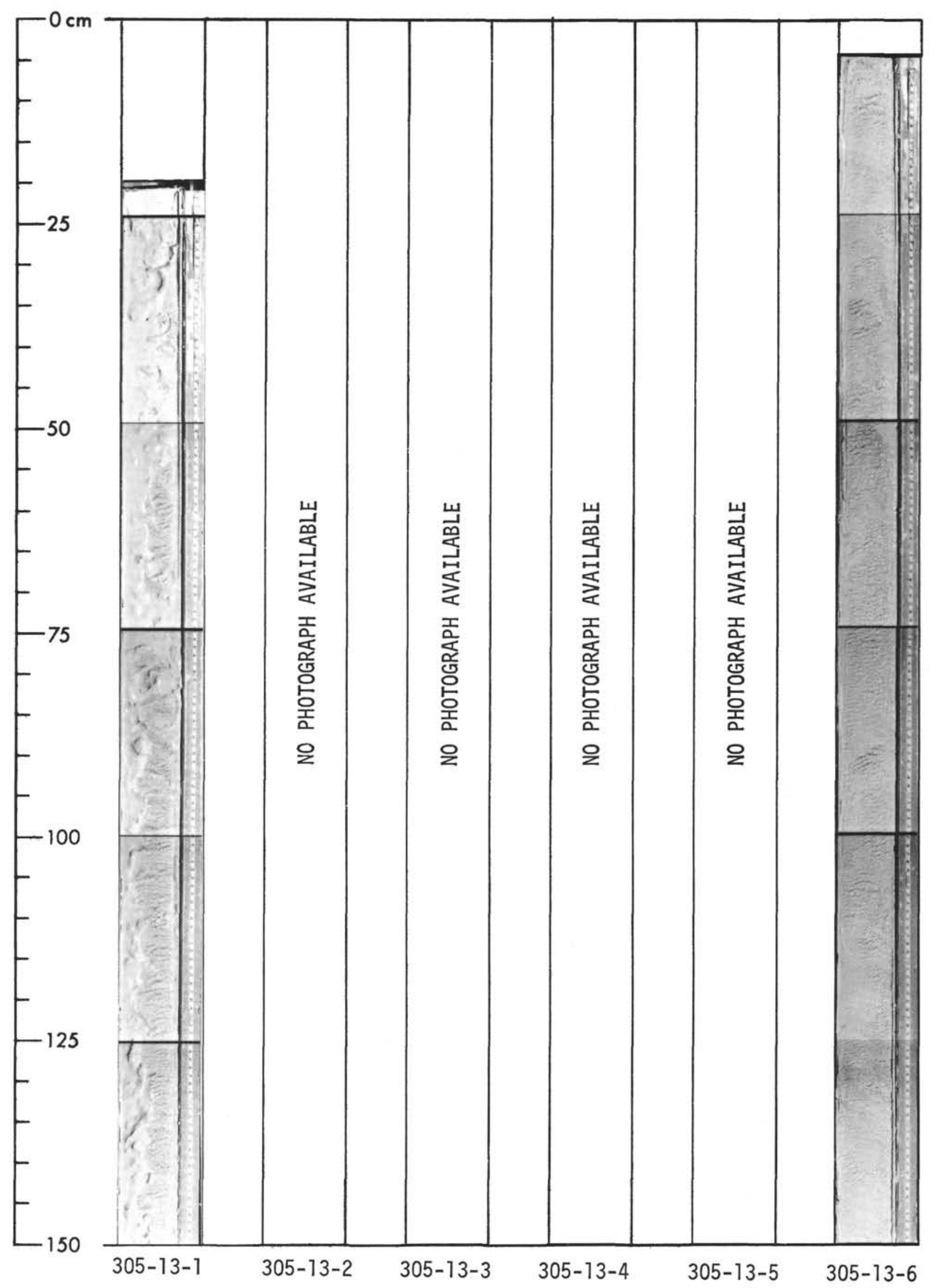


SITE 305

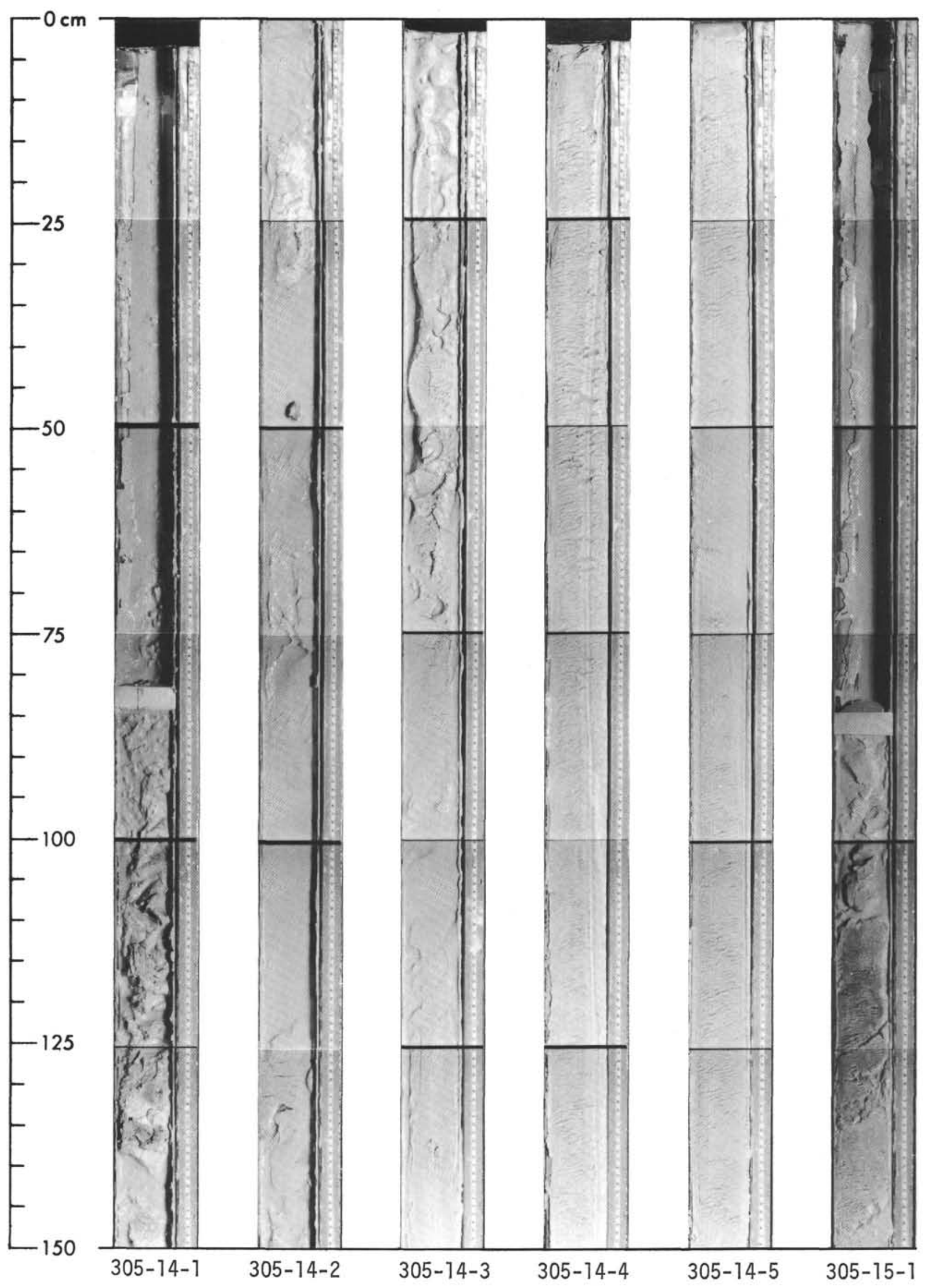




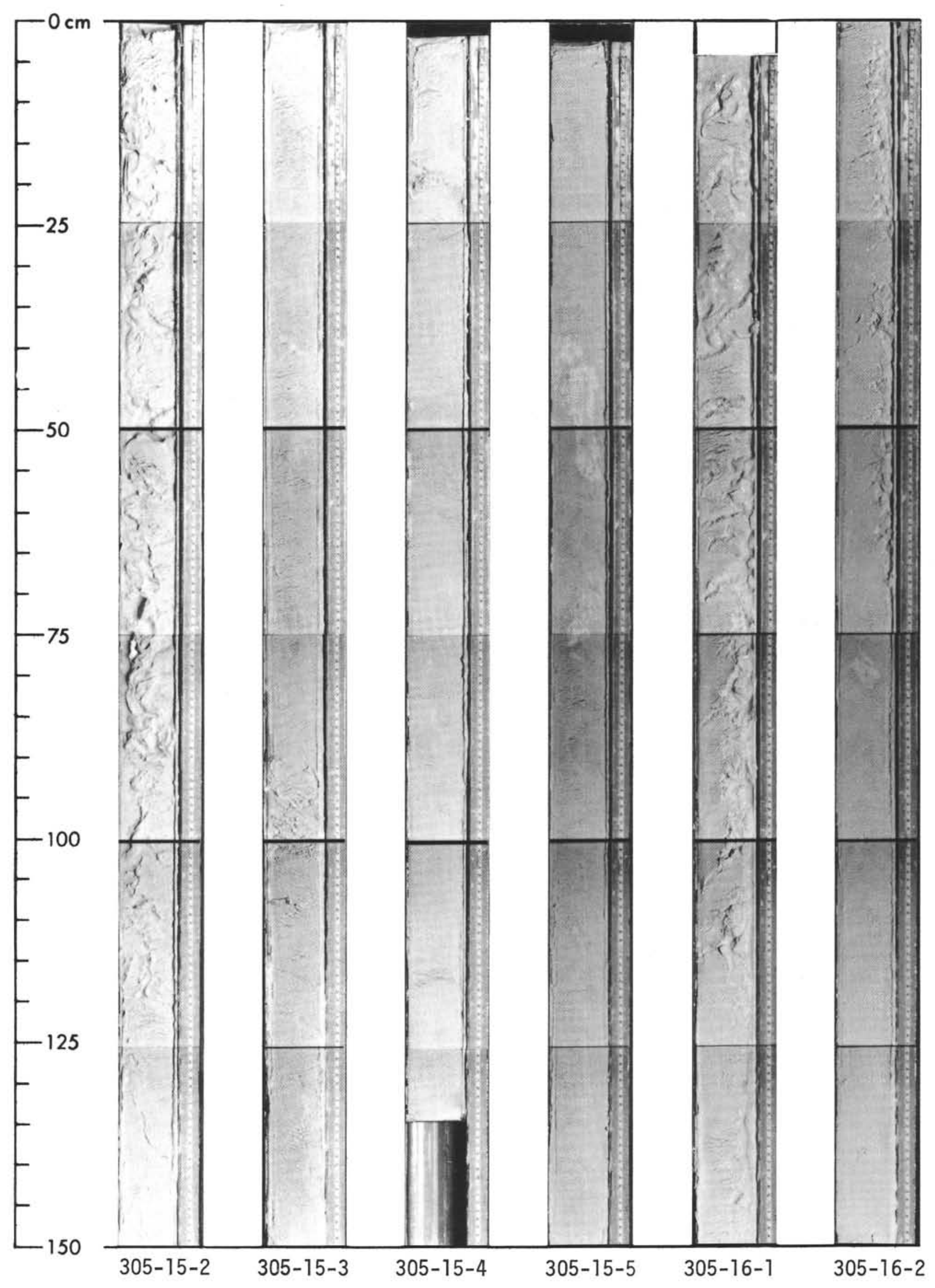




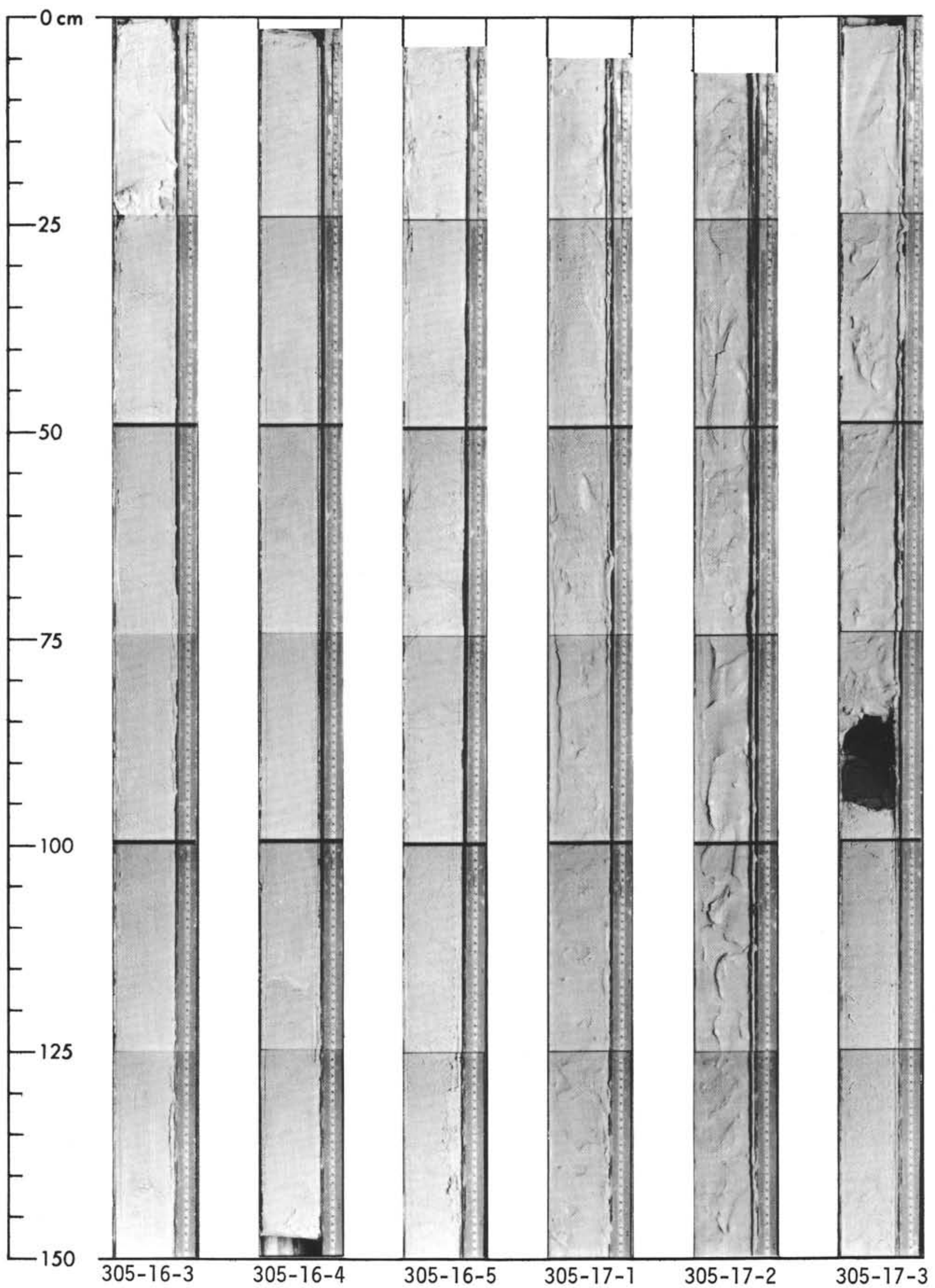




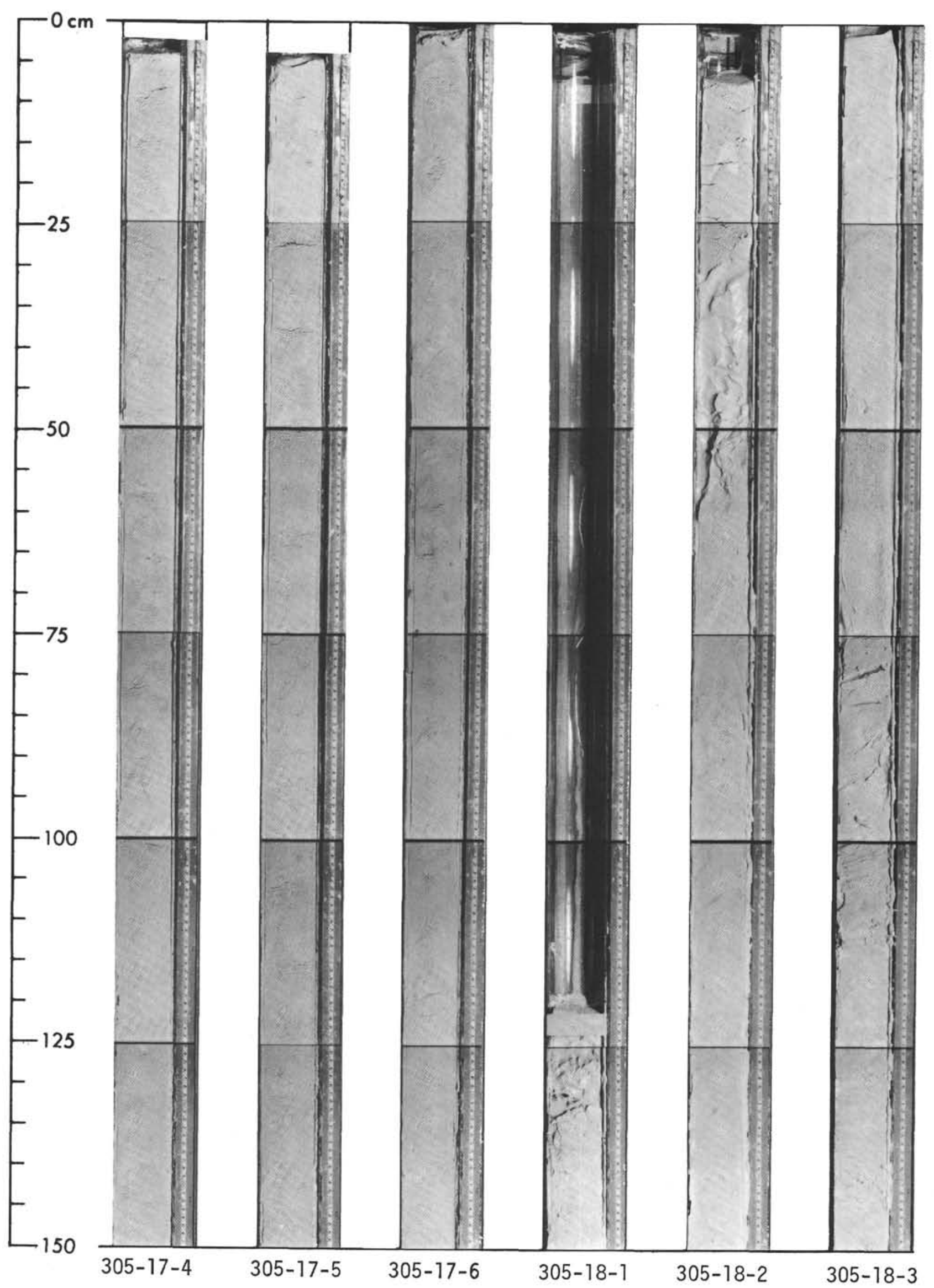




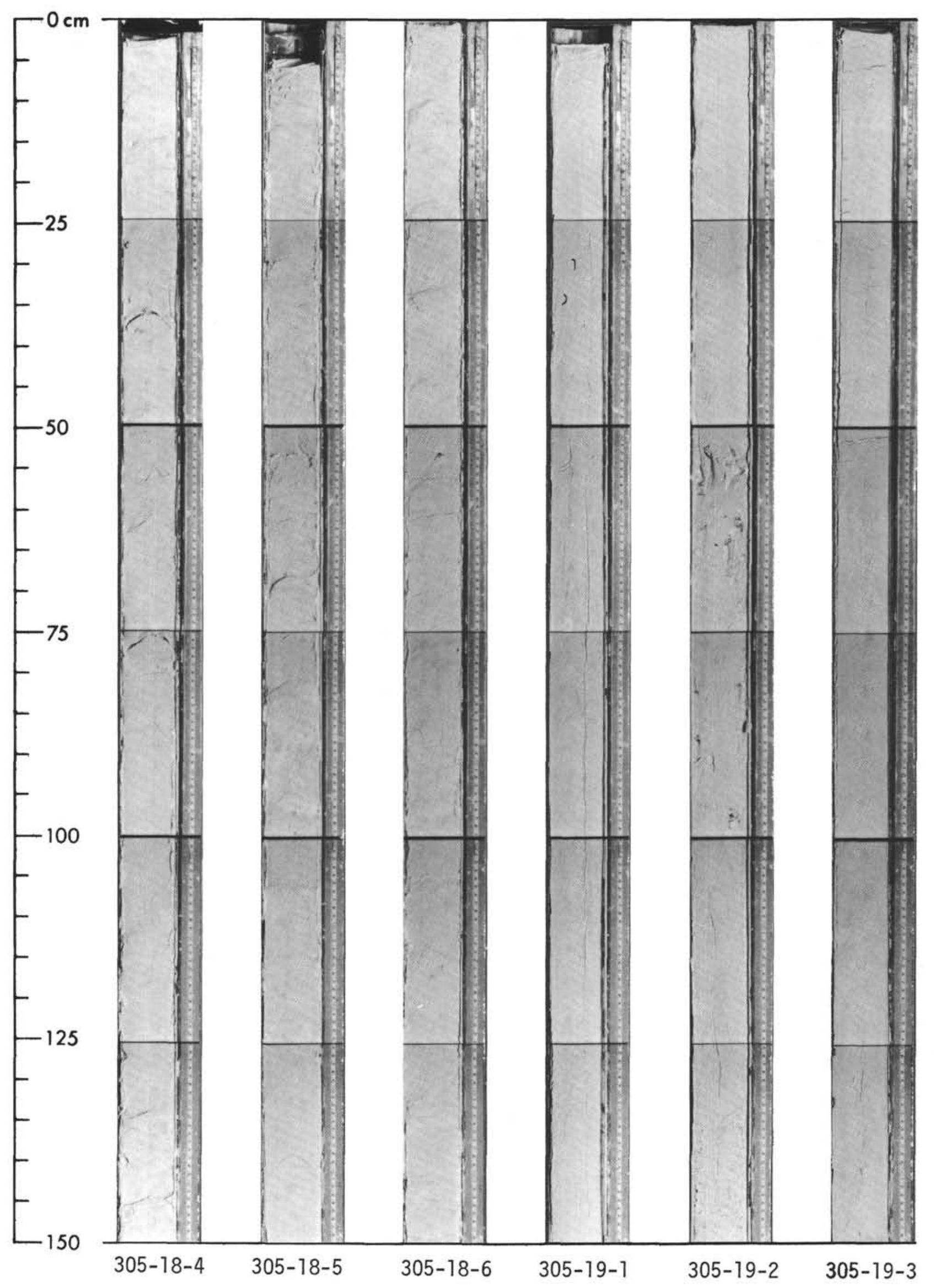




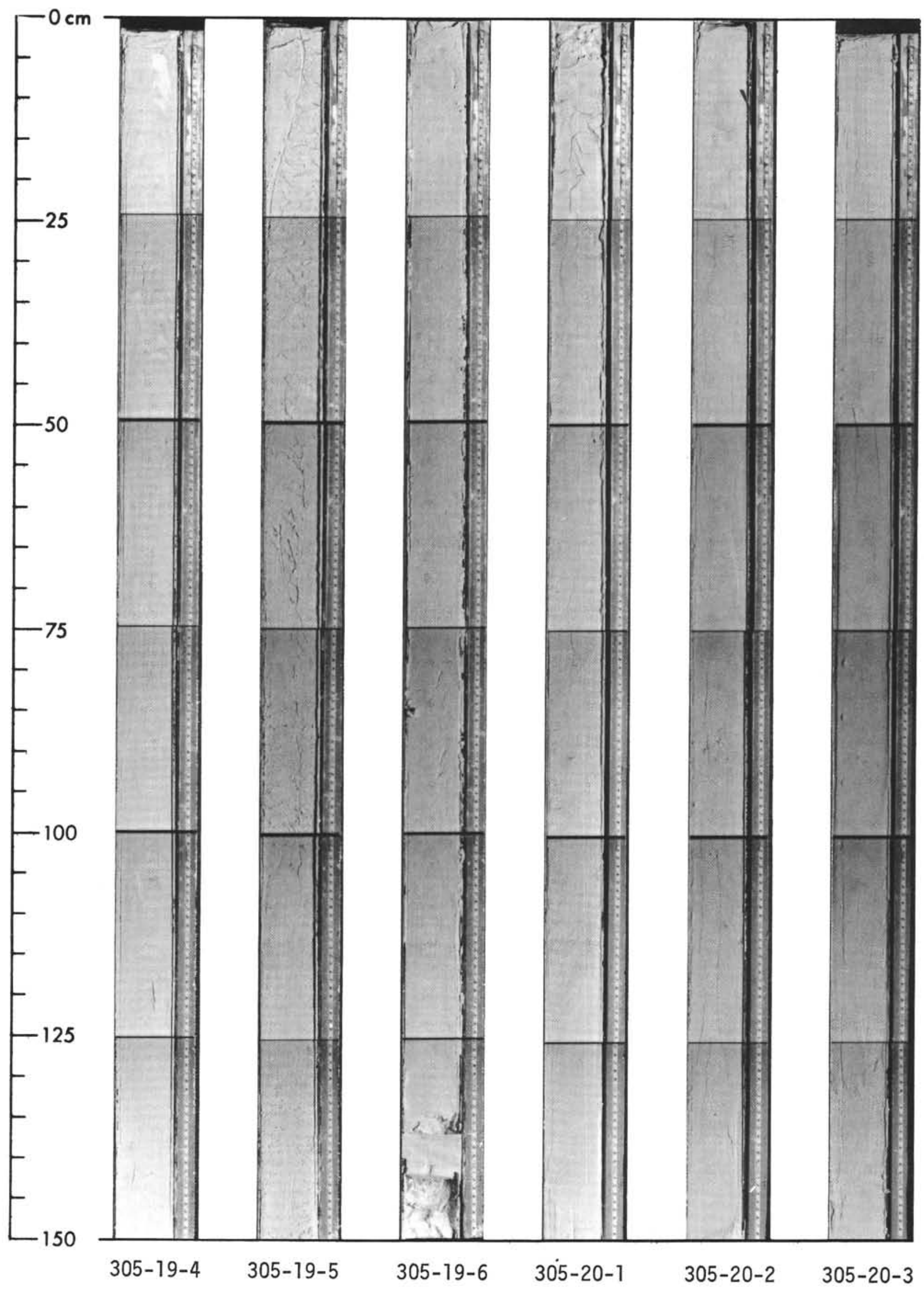




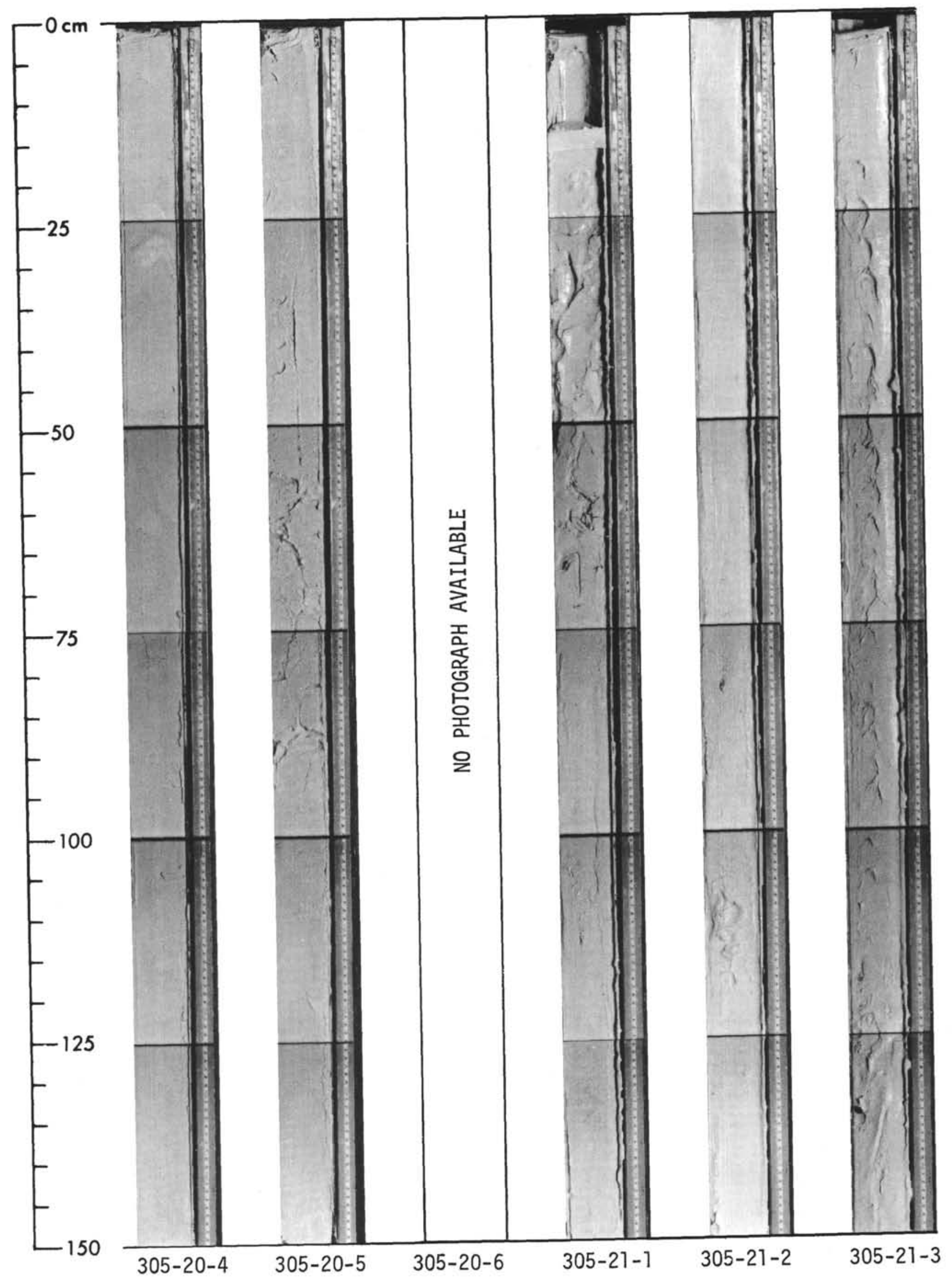




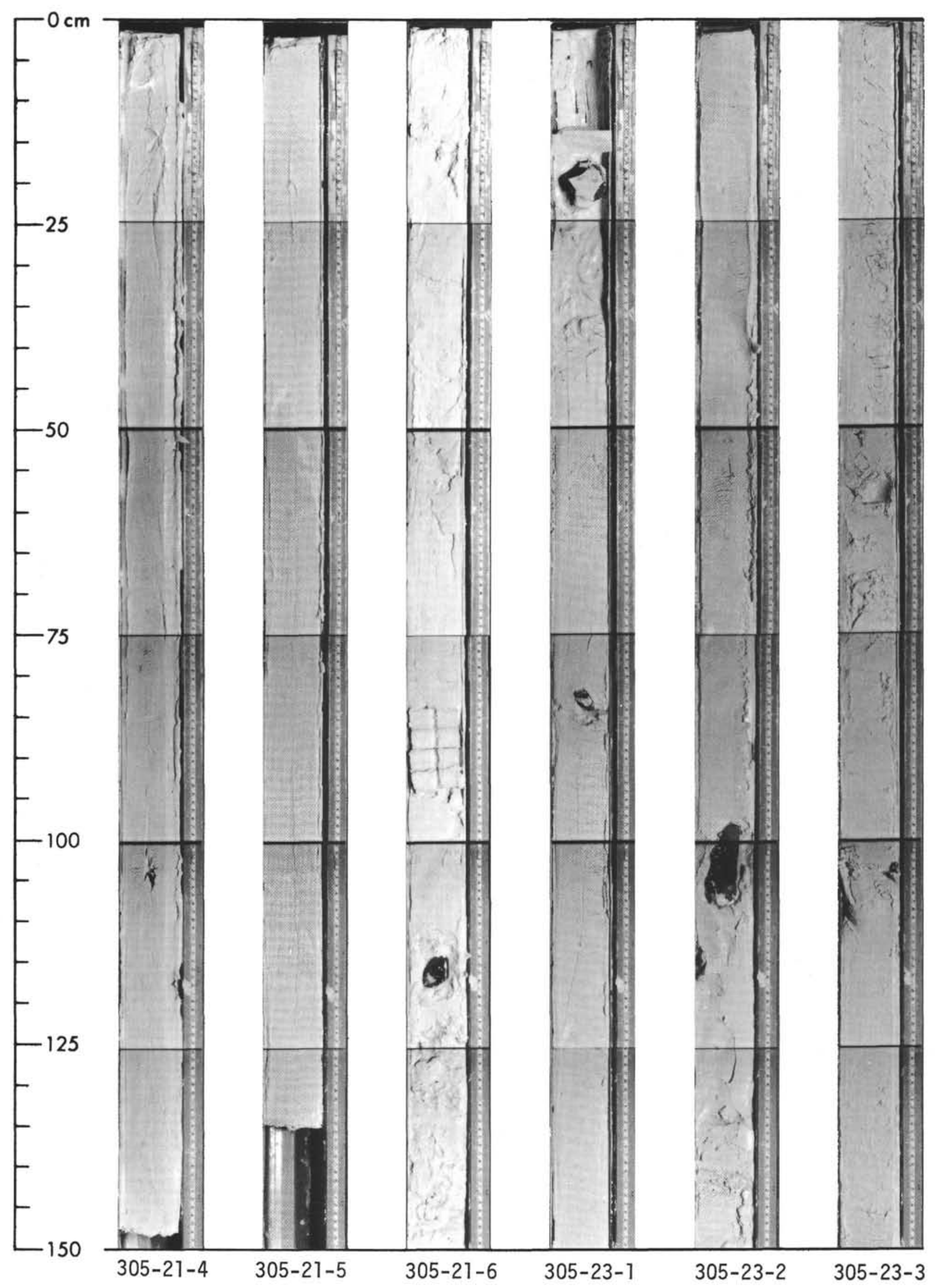




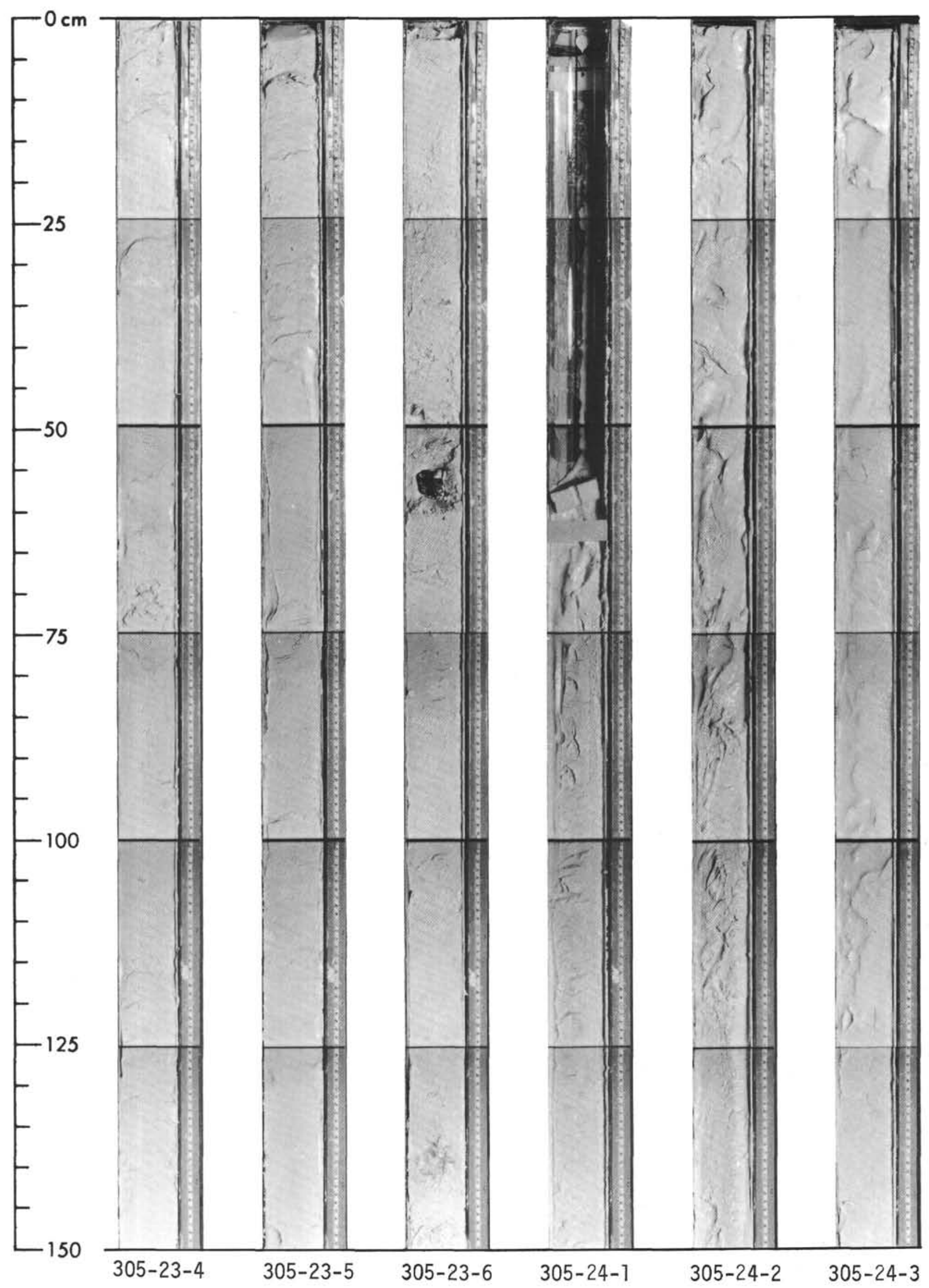




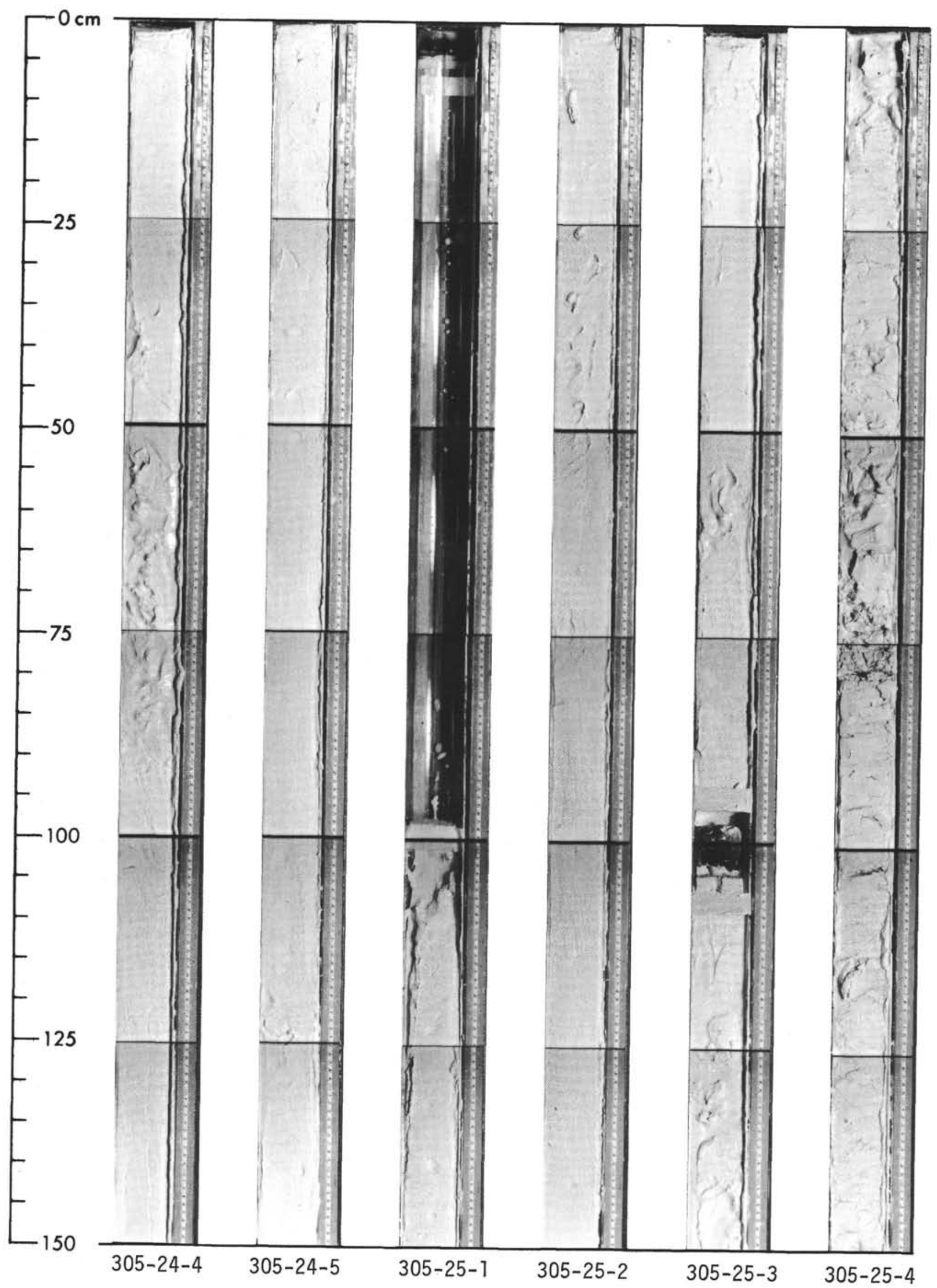




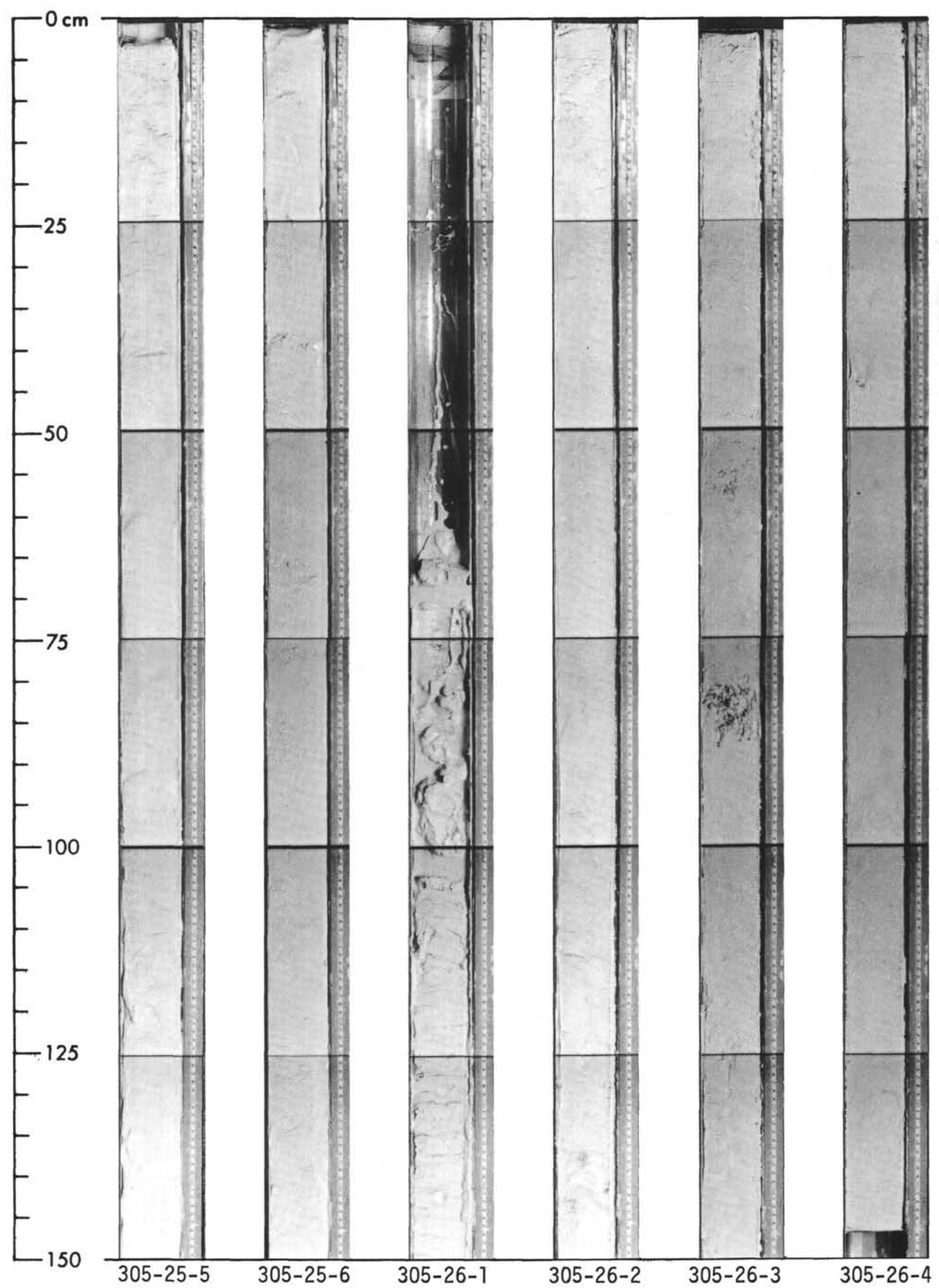




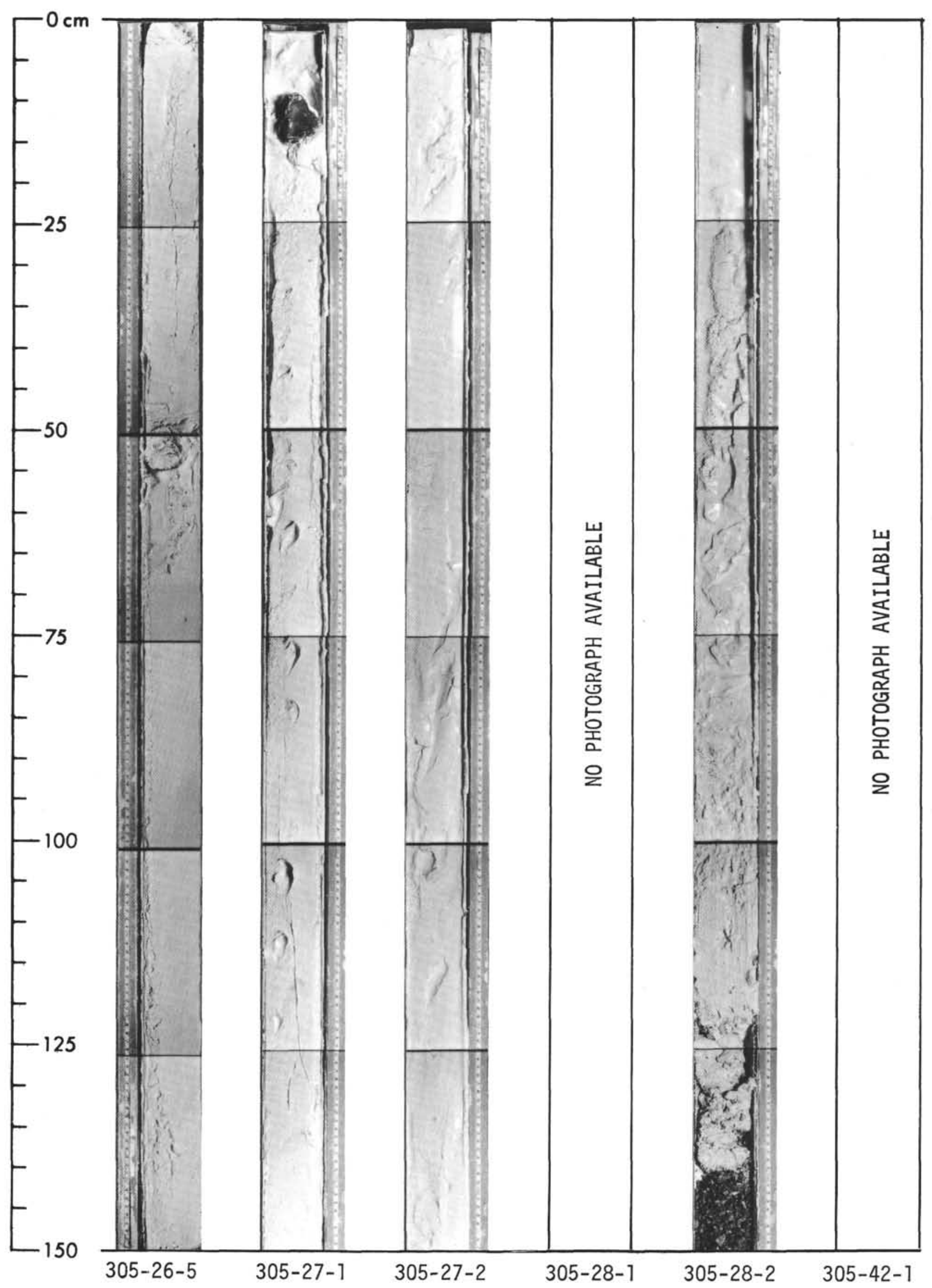


SITE 305

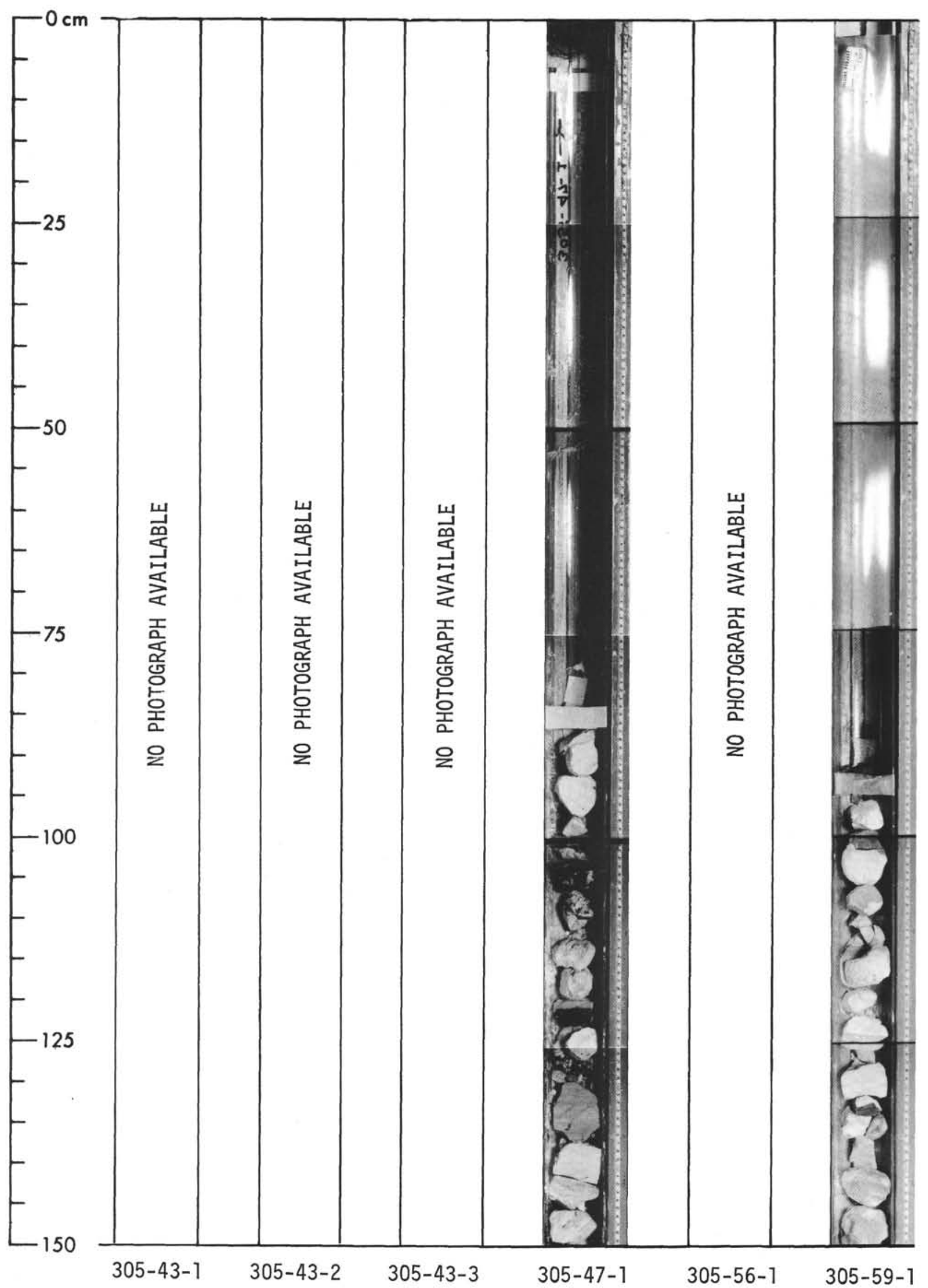




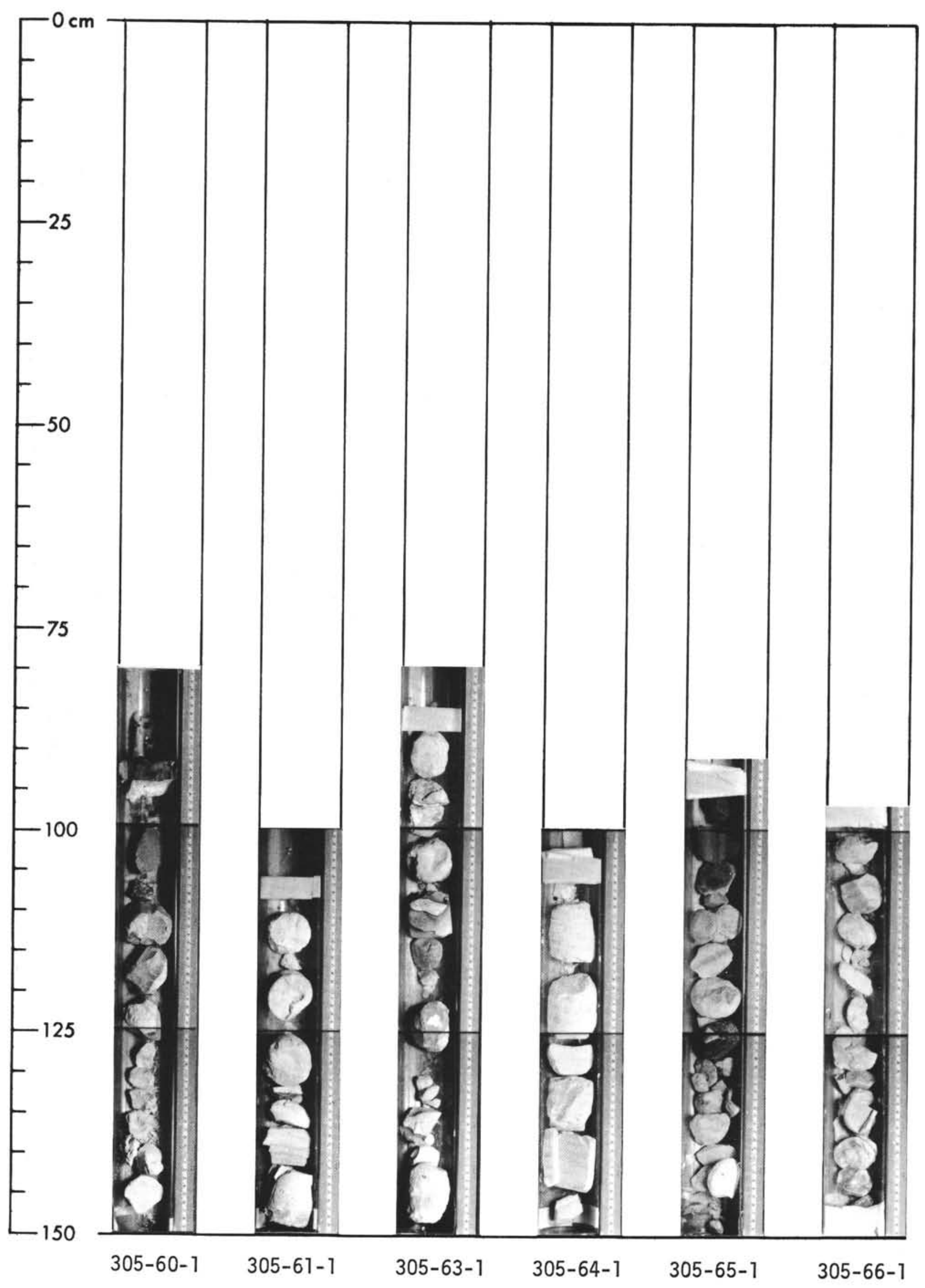

